

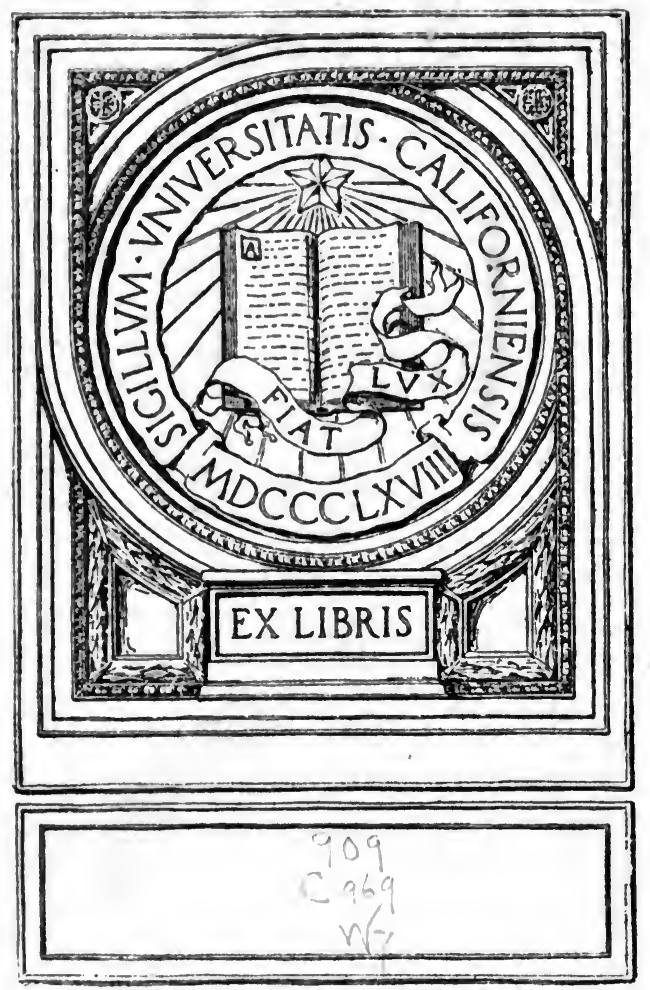




\section{Digitized by the Internet Archive in 2007 with funding from Microsoft Corporation}




RICHARD CUMBERLAND 

RICHARD CUMBERLAND 




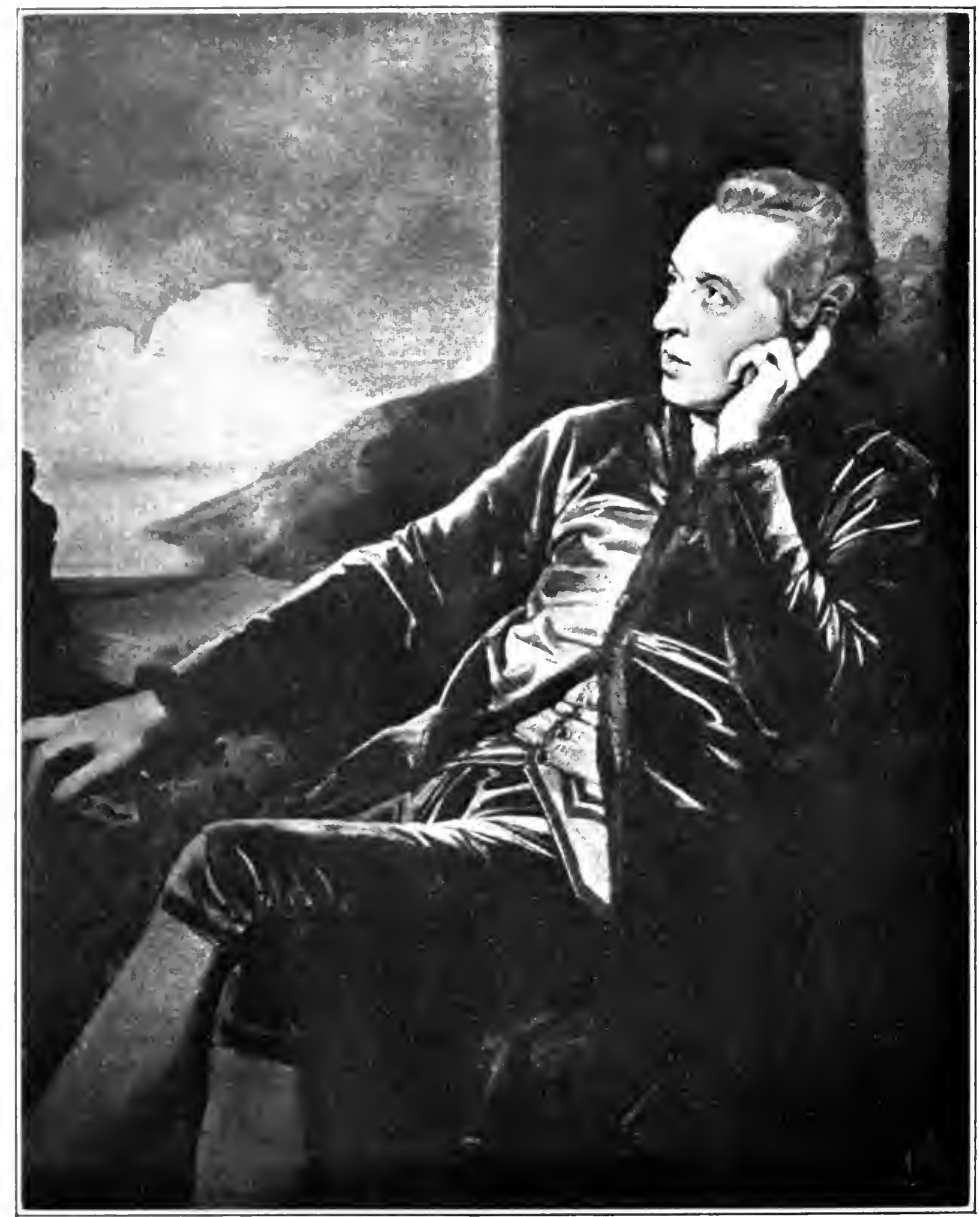

RICHARD CUMBERLAND

TII: ORIGINAI, PAINTING BY ROMNEV IS IN THE NATIONAL PORTRAIT GALLIRY 


\title{
RICHARD CUMBERLAND
}

\section{HIS LIFE AND DRAMATIC WORKS}

\author{
$\mathrm{By}$ \\ STANLEY THOMAS WILLIAMS, Рн.D.
}

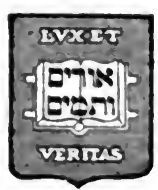

NEW HAVEN: YALE UNIVERSITY PRESS

LONDON: HUMPHREY MILFORD

OXFORD UNIVERSITY PRESS

MDCCCCXVII 
Copyright, 1917

By Yale University Press

First published, September, 1917

$$
\begin{aligned}
& \because \cdots \quad \because \because \because \vdots \vdots \vdots \\
& \because: \vdots \vdots \because \vdots \because \cdots \vdots \vdots \vdots \vdots \cdots \cdots
\end{aligned}
$$


To C. M. W. 



\section{PREFACE}

THREE years ago the writer was led by the renewed 1 interest in eighteenth century drama to begin a study of the plays of Richard Cumberland. He ends his work today, believing that the real interest of his book lies less in the plays than in the personality of their author.

Sources for this Life of Cumberland have been found in the collections of plays, memoirs, diaries, and letters in the Yale and Harvard University libraries, and in original manuscripts of Cumberland in the British Museum. Material has been drawn directly from the Memoirs of Richard Cumberland, written by himself, published in I 806, and from Mudford's Life of Richard Cumberland, which appeared in I 8 I 2, one year after the death of the dramatist. Unannotated quotations relative to Cumberland's life should be ascribed to the Memoirs.

The bibliography contains a complete record of authorities used but does not attempt a compilation of the innumerable editions of Cumberland's fifty-eight plays. It has seemed best, also, in what is primarily a biography of Cumberland, to omit much of the stage-history of his more obscure plays. An exhaustive account of these may be found in a thesis by the present writer, deposited, in I9 15 , in the Yale University Library. A general essay upon Cumberland's dramas is forthcoming in the Publications of the Modern Language Association.

I wish to express my gratitude to Professor George $\mathrm{H}$. Nettleton, who has directed my work. My thanks are also due to Professor Chauncey B. Tinker; Mr. Richard D. Cumberland-Jones of Ewen, Cirencester; Major 
General Cumberland, C.B., of the Manor, Maidstone; Mr. J. P. Gilson, of the Department of Manuscripts of the British Museum; Mr. George van Santvoord, of the Winchester School; Mr. Robert Gould Shaw, of Wellesley, Massachusetts; Miss Clara B. Underwood; Miss R. B. McLean; and Miss Mary Lee Rockwell of Meriden, Connecticut.

\section{Yale College, New Haven, Connecticut}

S. T. W.

May I, I9I 7 


\section{CONTENTS}

Preface

I. Birth and Early Education . . . I

II. College and Political Ventures . . $\quad$ I 9

III. Early Dramatic Efforts . . . 39

IV. Garrick-The Brothers . . . 44

V. The West Indian-David Garrick . 59

VI. The Fashionable Lover . . . 88

VII. Dramatic Achievement-Goldsmith . 105

VIII. Dramatic Achievement (continued) Sheridan-Death of Garrick . I 33

IX. Johnson and His Circle . . . $\quad$ I59

X. Ambassadorship to Spain . . . ${ }^{172}$

XI. At Tunbridge Wells as Man of Letters-

The Walloons-The Mysterious Husband . . . . . ${ }_{1} 84$

XII. At Tunbridge Wells (continued)-The Carmelite-The Observer . 20I

XIII. Renewed Success-The Jew-The Wheel of Fortune . . . $\quad 23 \mathrm{I}$

XIV. Cumberland's Novels-Brother Dramatists

$\mathrm{XV}$. The Veteran Cumberland . . . 264

XVI. Cumberland's Dramas . . . 302

Bibliography . . . . . . 330

Index 



\section{LIST OF ILLUSTRATIONS}

Richard Cumberland, from a painting by Romney,

\section{Frontispiece}

FACING PAGE

The Brothers, Act I . . . . . . . 52

The West Indian, Act IV . . . . . . 76

The West Indian, Act II .

The Fashionable Lover, Act I . . . . . . 94

Richard Cumberland, from a painting by Romney . I 6 The Wheel of Fortune, Act I . . . . $\quad 238$

Richard Cumberland, from a painting by Clover . 264 



\section{CHAPTER I}

\section{BIRTH AND EARLY EDUCATION}

THE life of Richard Cumberland has been neglected 1 for more than a century. It was a life of achievement, but achievement without the divine fire; of industry without inspiration; of strong and varied talents without genius. It was a life of success and disappointment, a life ennobled by service for England and England's literature, yet pitifully defaced by weakness. But it was a life so human that its interest blows away the dust of the years, and leaves discovered a personality real, vital, and unique in the history of English letters. Seldom has the alluring riddle of literary personality been more stimulating or more insoluble. In 1785 Fanny Burney wrote: 'How has he got these two characters-one, of Sir Fretful Plagiary, detesting all works but those he owns, and all authors but himself; the other too perfect even to know or conceive the vices of the world, such as he is painted by Goldsmith in Retaliation? and which of these characters is true ?'1

It is not as a literary eccentric that Cumberland compels interest. Nor do his forgotten works bring back the fame of 'The Terence of England.' Poems, novels, essays, and plays have perished deservedly, and brilliant bits of prose alone survive as symbols of their author's power. Cumberland's life was, first of all, one of great friendships. In the three-quarters of a century

${ }^{1}$ Diary and Letters of Madame D'Arblay, Dobson ed., 5.257. 
which he spanned he was the friend of men no less different in temperament and time than Samuel Johnson and Thomas Moore; in his literary musings may be found personal revelations of the great figures of the two ages in which he lived. He was a friend of Garrick, a patron of Romney, and, thirty years later, he knew Lord Byron, Walter Scott, and Samuel Rogers. He thus became a picturesque link between the literary circles of the eighteenth and nineteenth centuries.

Richard Cumberland boasted that he was 'descended from ancestors illustrious for their piety, benevolence and erudition.' He came of a family long distinguished for services to the church and literature of England and by virtue of his heritage of scholarly ideals he seemed destined to carry forward the torch of learning. His paternal great-grandfather was Richard Cumberland, the friend of Samuel Pepys. This scholar and philosopher, whom Cumberland praises for his approach towards 'consummate rectitude,' was, in I69I, made the Bishop of Peterborough, enjoyed wide renown as a divine and metaphysician, and when forty published his $D e$ Legibus Naturae, a work of significance among ethicists. ${ }^{2}$

The next Richard Cumberland, the only son of Bishop Cumberland and the grandfather of our dramatist, was the rector of Peakirk in the diocese of Peterborough, and also Archdeacon of Northampton. Of his two sons, Richard, the elder, died unmarried at the age of twentynine, and it was reserved for the younger, Denison, to uphold the traditions of the family. That this somewhat ascetic ideal was attained there can be little doubt, for his son, the subject of this life, gives an earnest testimonial of his good works. 'I declare to truth,' he says,

${ }^{2}$ See The Philosophical Review, 4.3; Bibliotheca Sacra, 43.528. 
'I never yet knew one so happily endowed with those engaging qualities, which are formed to attract and fix the love and esteem of mankind. It seemed as if the whole spirit of his grandfather's benevolence had been transfused into his heart, and that he bore as perfect a resemblance of him in goodness as he did in person.'

At the age of twenty-two Denison Cumberland married Joanna Bentley, and was persuaded by his father-in-law, Doctor Bentley, to accept the rectory of Stanwick in Northamptonshire. Here he lived quietly for thirty years with 'all men's good word in his favour and their services at his command.' Once only did he show his power of action. In the dark days before Culloden, when all stars seemed obscured save the Pretender's, and the rebels were advancing upon Derby, he loyally assembled and enrolled for the King two companies of one hundred men each, taking them in person to the Earl of Halifax. Many of these men lost their lives at the siege of Carlisle. Denison Cumberland's consequent favour with Halifax brought him, after a few years passed in the vicarage of Fulham, near London, promotion to the bishopric of Clonfert.

Ireland had sore need at this time of stout-hearted missionaries. In a country where violence was often the sole lord, and where amazing ignorance of the simplest means of life prevailed, Bishop Cumberland vigorously plied his practical Christianity. From 'a nook of land' on the river Shannon, 'on all sides save one surrounded by an impassable bog,' he directed his 'tribe of labourers, gardeners, turf-cutters, herdsmen and handicraft men of various denominations.' Many anecdotes have survived of his fight against barbarism. Among these is the story of Thomas O'Rourke, a tale often told at 
Samuel Rogers's dinner table by Richard Cumberland. O'Rourke, who was a labourer in the Bishop's garden, had already displayed his enthusiasm for the family by throwing 'a proper parcel of oatmeal into the air as a votive offering,' and burning his wig to their success. 'When,' says the Memoirs of Richard Cumberland, 'my father came down to Clonfert from Dublin it was announced .. . that the bishop was arrived: the poor fellow was then in the act of lopping a tree in the garden; transported at the tidings, he exclaimed-" "Is my lord come? Then I'll throw myself out of this same tree for joy-." $\mathrm{He}$ exactly fulfilled his word, and laid himself up for some months.' During the last years of his life Denison Cumberland served the more civilized see of Kilmore. He died in $\mathrm{I} 774$ while his son Richard was at Bath.

Perhaps it was from the maternal side that the subject of our study derived greater inspiration for scholarly endeavour. His lineage includes no greater name than that of his grandfather, Richard Bentley. In I 804 the grandson writes: 'His person, his dignity, his language, and his love of learning fixed my early attention, and stamped both his image and his words upon my memory.' Cumberland's story of his own childhood is a mosaic of Bentleian episodes. For him Bentley was never the stern enemy of Swift and Pope, but rather the friend and promoter of boyish sports. Many times the young Cumberland broke in upon him in his study, and, far from rebuking him, Bentley would 'ring his handbell for his servant, and be led to his shelves to take down a picture book.' Cumberland declares that he received but one reproof from Bentley,- - this after a thundering game of battledore and shuttlecock over the scholar's study! - and 
that he enjoyed his intervention in the family discipline. 'When,' Cumberland says, 'I was rallied by my mother, for roundly asserting that I never slept, I remember full well his calling on me to account for it; and when I explained it by saying I never knew myself to be asleep, and therefore supposed I never slept at all, he gave me credit for my defence, and said to my mother, "Leave your boy in possession of his opinion; he has as clear a conception of sleep, and at least as comfortable an one, as the philosophers who puzzle their brains about it, and do not rest so well."'

Cumberland's accounts of Bentley's benevolence at home have picturesque interest, though they surprised the generation that read the Memoirs. 'Slashing Bentley with his desperate hook' will persist, however much Cumberland denounced Pope for having written his couplets. The poet's observations upon Bentley's hat moved Cumberland to rather absurd protest. Pope writes:

His $H$ at, which never vailed to human pride, Walker with reverence took, and laid aside.

Cumberland's defence of his grandfather's hat is not without a humorous aspect. 'The petulant poet,' he says, 'who thought he had hit his manner, when he made him haughtily call to Walker for his hat, gave a copy as little like the character of Bentley, as his translation is like the original of Homer. That Doctor Walker, vicemaster of Trinity-College, was the friend of my grandfather, and a frequent guest at his table, is true; but it was not in Doctor Bentley's nature to treat him with contempt, nor did the harmless character inspire it. As for the hat, I must acknowledge it was of formidable dimensions, yet I was accustomed to treat it with great familiarity, and if it had ever been further from the hand of the owner than 
the peg upon the back of his great arm-chair, I might have been dispatched to fetch it, for he was disabled by the palsy in his latter days; but the hat never strayed from its place, and Pope found an office for Walker, that I can well believe he was never commissioned to in his life.'

The worship of Bentley's genius by the Cumberland family occasionally took the form of regretting that it had not been creative. On Cumberland's mother lamenting to her father that so little of his talent had been given to original work, 'Bentley acknowledged the justice of her regret with extreme sensibility, and remained for a considerable time thoughtful and seemingly embarrassed by the nature of her remark; at last recollecting himself he said, "Child, I am sensible I have not always turned my talents to the proper use for which I should presume they were given me: yet I have done something for the honour of my God and the edification of my fellow creatures; but the wit and genius of those old heathen beguiled me, and as I despaired of raising myself up to their standard upon fair ground, I thought the only chance I had of looking over their heads was to get upon their shoulders." 'This reverence of Bentley's for scholarship deeply influenced Cumberland.

The influence was strengthened by his mother, Joanna Bentley Cumberland. When, in I 7 I 4, John Byrom wrote his gay Colin and Phebe for The Spectator, all declared that Phebe could be no other than Joanna or 'Jug' Bentley.

My time, $\mathrm{O}$ ye Muses, was happily spent,

When Phebe went with me wherever I went;

Ten thousand sweet pleasures I felt in my breast:

Sure never fond shepherd like Colin was blest! 
But now she is gone, and has left me behind, What a marvellous change on the sudden I find!

When things seemed as fine as could possibly be,

I thought 'twas the Spring; but alas! it was she.

Cumberland affirms that his mother was the inspirer of these lively lines, but it now seems far more likely that the poet had in mind his own sister, Phebe Byrom. If not Byrom, Miss Bentley stirred other singers, and had her day as the toast of beauty and wit. Mr. Vere Foster, writing his friend, James Bonwicke, in 1722 , sends him 'what has been a long time the vogue of every tea table in college, namely, Mr. Prior's Lamentation for the loss of Mrs. Joanna Bentley.' These verses, written by E. Prior, give a happy picture of youth and mirth. They run, in part:

Exil'd from Juggy, from the window driven, Each rhymer's subject, and each coxcomb's heaven,

From strains of love in strains of grief I flow,

And tune my fiddle to melodious woe,

Doomed to lament ( $O$ transitory dream!)

The loss of beauty and the loss of cream. ${ }^{3}$

But 'Juggy' was Richard Bentley's daughter. It was she who aroused and formed the boy's literary taste, opening for him Shakespeare's realm of gold, and showing him the visions of the inward eye. His first dramatic piece, Shakespear in the Shades, was a result of her teaching. 'She had,' says her son, 'a vivacity of fancy and a strength of intellect, in which few were her superiors: she read much, remembered well and discerned acutely: I never knew the person, who could better embellish any subject she was upon, or render common incidents

${ }^{3}$ Nichols, Literary Anecdotes of the Eighteenth Century, 1.224. 
more entertaining by the happy art of relating them. . . . There hardly passed a day, in which she failed to devote a portion of her time to the reading of the Bible; and her comments and expositions might have merited the attention of the learned. Though strictly pious, there was no gloom in her religion, but on the contrary, such was the happy faculty, which she possessed, of making every doctrine pleasant, every duty sweet, that what some instructors would have represented as a burden and a yoke, she contrived to recommend as a recreation and delight.' Cumberland's final tribute to this unusual woman is suggestive of her part in his life: 'All that son can owe to parent, or disciple to his teacher, I owe to her.'

An ardent hereditarian with a knowledge of Cumberland's ancestry would willingly hazard a guess concerning his character. Nor would the place of his birth seem meaningless. He was born, on February I9, I 732, in the Master's Lodge of Trinity College, under the roof of Doctor Bentley, and literally, as he himself says, Inter sylvas Academi. Yet in the earliest years the child was not the father of the man. His first picture of himself is as a tiny mutineer against the alphabet, rebelling against all learning, and, in particular, against the one hundred and fifteenth psalm, which he had been compelled to absorb entire. Cumberland found no brothers to vie with him, but had the humiliation of seeing his sister Joanna, who was two years older, far outstrip him in learning.

Other buffets lay in store for him. Reluctant students had no place in the Cumberland family, and at the age of six Richard was sent to school at Bury St. Edmund. Bury St. Edmund School, whose system was based upon 
that of Westminster, was at this time prosperous and of high standing as an educator of younger boys. Arthur Kinsman was then head-master, and ruled his one hundred and fifty charges with a hand at once stern and kindly. The descendant of Richard Bentley, who was Kinsman's life-long friend, received no inconsiderable share of the pedagogue's attention. Kinsman is reported to have said to Doctor Bentley: 'Master, I will make your grandson as good a scholar as yourself.' And to this Bentley in the like vein of raillery replied: 'Pshaw, Arthur, how can that be, when I have forgot more than thou ever knew'st?' Kinsman's prophecy was fulfilled in a greater measure than he had expected; the name of Bentley was not disgraced by Cumberland. Kinsman and Bentley, more than others, brought the boy Cumberland to a knowledge of himself and of his powers.

Cumberland's own account of his intellectual dawn has interest: 'The penetrating eye of old Kinsman discovered the grandson of his friend far in the rear of the line of honour, and in fair train to give the flattest contradiction to his prophecy. Whereupon one day, which by me can never be forgotten, calling me up to him in his chair at the head of the school, he began with much solemnity to lecture me very sharply, whilst all eyes were upon me, all ears open, and a dead silence, horrible to my feelings, did not leave a hope that a single word had escaped the notice of my school-fellows. I well remember his demanding of me what report I could expect him to make to my grandfather Bentley. I shuddered at the name, even at that early age so loved and revered: I made no defense; I had none to make, and he went thundering on, farther perhaps than he need to have gone, had he given less scope to his zeal, and 
trusted more to his intuition, for the keenness of his reproof had sunk into my heart; I was covered with shame and confusion; I retired abashed to my seat, which was the lowest in the school: I hid my face between my hands, resting my head upon the desk before me, and gave myself up to tears and contrition: When I raised my eyes I thought I discovered contempt in the countenances of the boys.' 'At that moment,' declares Cumberland, 'the spirit of emulation, which had not yet awaked in my heart, was thoroughly roused.'

A pleasanter picture of the youthful Cumberland and his mentors has come down to us from a visit paid by Kinsman to Bentley at Trinity Lodge, where the boy passed his holidays. Encouraged by the gentler manners of the schoolmaster outside the classroom, he stood by the savants, eyes and ears open. He heard Bentley declare that Barnes knew as much Greek as 'an Athenian blacksmith'; that Pope's Homer was 'an elegant poem but no translation'; that while Warburton possessed a voracious appetite for knowledge, he had not.' a good digestion.' Best of all, he heard Greek roll 'in torrents from the lips of Bentley as the most learned of moderns chanted forth the inspired rhapsodies of the most illustrious of antients in a strain delectable indeed to the ear.' These were good hours for Cumberland.

Kinsman's public shaming had shaken his very soul, and he now set about his work in sober earnest, displaying at once the trend of what was to be a powerful mind. $\mathrm{He}$ was soon in his rightful place at the head of the school. 'I entered the lists,' he says, 'with all possible advantages, and soon found myself able to break a lance with the very best of my competitors.' Two of the competitors were the brothers Warren, later distinguished in 
the church and in medicine. Cumberland's serious pursuit of learning was encouraged by private coaching from Kinsman. 'From this time,' he writes, 'I may truly say my task was my delight. I rose rapidly to the head of my class, and in the whole course of my progress through the upper school never once lost my place of head boy, though daily challenged by those, who were as anxious to dislodge me from my post as I was to maintain myself in it.' It is possible to see in this over-serious youthful point of view the beginning of a habit which darkened many later hours.

Even Cumberland's pranks had a bookish tinge. With his fellows he planned a surreptitious performance of the tragedy of Cato. Cato's entire costume consisted of 'a full bottomed periwig,' while Portia and Marcia rejoiced in raiment borrowed from the maids of a near-by lodging-house. The Thespians were discovered; 'the virtuous Marcia,' played by 'a most ill-favored, wrynecked boy,' was heartily cuffed by Kinsman; and the dramatis personae were publicly chagrined. Cumberland, who had essayed the rôle of Juba, received as his share of the general punishment the tenth satire of Juvenal.

Perhaps these compulsory verses stimulated the writing of others. Certainly during the last years at Bury the boy's main interest lay in experimenting with versification. The first attempt was a hundred-line description of the docks at Portsmouth and the races at Winchester. The lines bear no trace of poetic power, and the sole surviving quatrain suggests the reason for their existence:

Since every scribbler claims his share of fame, And every Cibber boasts a Dryden's name, Permit an infant muse her chance to try; All have a right to that, and why not I? 
Another poetic effort of no value, but of interest as foreshadowing the future was the pseudo-dramatic production, written at the age of twelve, christened Shakespear in the Shades. Divers unhappy personages from the pages of Shakespeare are discovered in Elysium, and here the poet comes, 'the instrument of Providence,' to comfort them. A long speech in prose by Shakespeare begins the drama, and the reader is then introduced into the surprising assembly of Hamlet and Ophelia, Romeo and Juliet, and Lear and Cordelia. The piece concludes with a moral dialogue between Romeo and Shakespeare.

The sheltered life of Bury St. Edmund with the long vacations at Stanwick was soon exchanged for one of more rigid discipline. In 1744 Cumberland entered Westminster School. The lustre of Westminster's past doubtless affected him strongly. Here were reverenced the names of Udall, Camden, Herbert, Donne, Cowley, Dryden, and Locke, and a host of other distinguished sons. Although only in his thirteenth year, Cumberland was placed in the Shell, or intermediate form. His school-fellows bade fair to uphold the honour of Westminster. Vincent Bourne was then usher of the fifth form. 'I love,' writes William Cowper, 'the memory of Vinny Bourne. I think him a better Latin poet than Tibullus, Propertius, Ausonius, or any of the writers in his way, except Ovid, and not at all inferior to him. I love him, too, with a love of partiality, because he was the Usher of the Fifth Form at Westminster when I passed through it. . . . I remember seeing the Duke of Richmond set fire to his greasy locks, and box his ears to put it out again." Pierson Lloyd, the father of the more famous Robert Lloyd, and under-master in 1748 , was

${ }^{4}$ The Correspondence of William Cowper, Wright ed., 1.310. 
in the fourth form, and Clayton Cracherode, later renowned as an antiquarian, was in the head election. Cumberland found Cracherode 'as grave, studious and reserved as he was through life; but correct in morals and elegant in manners, not courting a promiscuous acquaintance, but pleasant to those who knew him, beloved by many and esteemed by all.' The story is told of this recluse that though he had a very curious chestnut tree on his grounds in Hertfordshire, he knew of it only by means of a drawing in his possession.

Cumberland has little to say about his school-fellows at Westminster. He dismisses casually such well-known figures at Frederick Augustus Hervey, fourth Earl of Bristol, George Hobart, third Earl of Buckinghamshire, and Thomas Harley, twice Lord Mayor of London. He says nothing of Warren Hastings, although he must have known him in all the charm of his youth, his sweet, kindly nature making him beloved at Westminster. 'What,' once exclaimed the doctor, when there was talk of Hastings leaving the school, 'lose Warren Hastings! lose the best scholar of his year! . . he shall go on with his education at my charge.' ${ }^{\prime 5}$ Of George Colman, the elder, and Robert Lloyd, Cumberland makes but passing mention. Perhaps his rivalry with Colman began even in these early years, and he could have but little in common with Lloyd,

born sole heir and single

Of dear Mat Prior's easy jingle.

It was at Westminster that Robert Lloyd first met Churchill, and his devoted friendship for him was the real cause of a wasted life. It is possible, though not

${ }^{3}$ Forshall, Westminster School, Past and Present, 239-40. 
probable, that Cumberland was a member of the 'Nonsense Club,' 'consisting of seven Westminster boys who dined together every Thursday.' To it belonged Bonnell Thornton, Colman the elder, Cowper, Joseph Hill, and Robert Lloyd. The little space given these men in the Memoirs seems to prove that they were not Cumberland's close friends. But Cowper, who roomed in the same house with Cumberland, found him clever even in those days. ${ }^{\circ}$ In regard to less famous members of the school, Cumberland is eloquent. He has much to say of John Hinchliffe, Samuel Smith, and William Vincent, all his comrades, and subsequently all head-masters of Westminster.

As at Bury St. Edmund, Cumberland was more deeply affected by his teachers than by his fellows. Doctor Johnson, later Bishop of Worcester, was at this time second master. John Nicoll had been head-master since r733, and his manliness had long since won the affection and respect of every boy in the school. 'Arthur Kinsman,' says Cumberland, 'certainly knew how to make his boys scholars; Doctor Nicoll had the art of making his scholars gentlemen.' Under his rule public contempt was a punishment compared to which the sentence of the rod would have seemed an acquittal or a reprieve. Cumberland goes on to tell the story of a boy who had offended the high spirit of the school by a dishonourable act. Doctor Nicoll, after laying the case before the seniors, asked their opinion of the misdemeanor, and what they considered a just punishment. 'Their answer was unanimously, "The severest that could be inflicted." "I can inflict none more severe than you have given him," said the master, and dismissed him without any other

- The Correspondence of William Cowper, Wright ed., 3.336. 
chastisement.' Cumberland himself tested the doctor's discipline. He had escaped from the abbey for the purpose of disturbing a Quakers' meeting, and was called before the doctor. 'I presume,' says Cumberland, 'he saw my contrition, when turning a mild look upon me, he said aloud, "Erubuit salva est res (he has blushed; all is well)," and sent me back to my seat.' At another time Cumberland was guilty of a literary sin which an enemy might call prophetic of future evil deeds. He handed in to Doctor Nicoll a copy of Latin verses all of which he had pirated from Duport. The doctor, having read the lines aloud to the seniors, praised them highly. This was too much for the youthful plagiarist, and he confessed his weakness. 'Child,' said Doctor Nicoll, 'I forgive you, go to your seat, and say nothing of the matter. You have gained more credit with me by your ingenious confession, than you could have got by your verses, had they been your own.' 'Was it possible,' says Cumberland, 'not to love a character like this?'

Although he was a short time at Westminster, Doctor Nicoll and the spirit of the school made a lasting impression upon him. He remained half a year in the Shell and one year in the sixth form, and afterwards declared his deep content with this period of his life. 'I did not indeed,' he says, 'drink long and deeply at the Helicon of that distinguished seminary, but I had a taste of the spring and felt the influence of the waters. In point of composition I particularly profited, for which I conceive there is in that school a kind of taste and character, peculiar to itself, and handed down perhaps from times long past, which seems to mark it out for distinction, that of having been above all others the most favored cradle of the Muses.' 
But even in these years deeper forces than those of Westminster left their mark upon Cumberland. He had now his first sense of sorrow. In I 746, Joanna, his eldest sister, fell ill in London of the smallpox, and, after a distressing illness, died. 'My father,' writes Cumberland, 'who tenderly loved her, submitted to the afficting dispensation in silent sadness, never venting a complaint; my mother's sorrows were not under such controul, and as to me, devoted to her as I had been from my cradle, the shock appeared to threaten me with such consequences, that my father resolved upon taking me out of town immediately, and we went down to our abode at Stanwick, a sad and melancholy party.' Archdeacon Cumberland's decision was a wise one, and doubtless saved the health of the impressionable Richard, who suffered for some time a dangerous depression of spirits. In his anxiety for his son the father decided against another year at Westminster, and set about planning for his entrance into Trinity College, Cambridge.

Before these plans were matured, however, occurred an event, seemingly slight in itself yet full of meaning. While staying with his uncle, Edmund Ashby, in Peter Street, Cumberland visited the theatre. Here, on a memorable evening, he saw Nicholas Rowe's Fair Penitent ${ }^{7}$ with Quin, Mrs. Cibber, and David Garrick in the principal rôles. The strange new genius of Garrick was still amazing London. 'If this young fellow is right,'

"The Fair Penitent was first performed at Lincoln's Inn Fields in 1703. This play, Walter Scott said, fell as far below Massinger's play, of which it was an adaptation, as the boldest translation can sink below the most spirited original. In Cumberland's collection of essays, called The Observer, may be found a detailed comparison of Massinger's Fatal Dowry and Rowe's Fair Penitent. See Nos. 77, 78, 79. See also John Taylor, Records of My Life, 12.161. Garrick played Lothario in The Fair Penitent for the first time on December 2, 1741. 
Quin had said, 'then we are all wrong!' And wrong the old actors were. Apostasy flourished. The natural school of acting had come to stay. While the conventional ranting continued, it was often to empty benches, and meanwhile the crested chariots of England's beau monde thronged the narrow streets of Goodman's Fields where the greatest of actors held forth. Garrick and Quin frequently acted together, and it was Cumberland's privilege to see them in a play in which both excelled.

So graphic is his story of those intense moments when he saw before him the old and new schools of acting contending for supremacy, that it has found its way into numerous records of the stage, and must be requoted here. The glories of early eighteenth century acting cannot be better set forth than in the following: 'Quin presented himself upon the rising of the curtain in a green velvet coat embroidered down the seams, an enormous full bottomed periwig, rolled stockings and high-heeled square-toed shoes: with very little variation of cadence, and in a full deep tone, accompanied by a sawing kind of action, which had more of the senate than of the stage in it, he rolled out his heroics with an air of dignified indifference, that seemed to disdain the plaudits that were bestowed upon him.'

Cumberland was from the first an excellent judge of acting. He found Mrs. Cibber's 'high-pitched but sweet . . strain' wearisome, 'eternally chiming in the ear without variation or relief.' He turned from her, and from Quin, instinctively unsatisfied, and was instantly converted to the new school of acting at the first appearance of its leader. 'When,' he says, 'after long and eager expectation I first beheld little Garrick, then young and light and alive in every muscle and in every feature, come 
bounding on the stage, and pointing at the wittol Altamont and heavy-paced Horatio-heavens, what a transition!-it seemed as if a whole century had been stept over in the transition of a single scene. . . . I thank my stars,' he concludes, 'my feelings in those moments led me right; they were those of nature, and therefore could not err.' It is Cumberland's instant recognition of Garrick's acting as the only true art, at a time when Garrick's methods were not finding complete acceptance in audiences of the day, that establishes his judgment of dramatic values. This was but an incident in a long lifetime, yet it created Cumberland's ideal, and was, perhaps, the beginning of a devotion to Garrick which persisted until the actor retired from the stage. 


\section{CHAPTER II}

\section{COLLEGE AND POLITICAL VENTURES}

IN I 745, in his fourteenth year, Cumberland entered 1 Trinity College, Cambridge. During the first two years, however, he made little progress towards his degree. Deserted by lazy tutors, and thrown upon his own resources, he passed the time as he pleased. But his intensely earnest and ambitious spirit forbade all dissipation, and his story of this time has an overtone of priggishness. 'I certainly did not,' he says, 'wantonly misuse my time, or yield to any even of the slightest excesses, that youth is prone to: I never frequented any tavern, neither gave nor received entertainments, nor partook in any parties of pleasure, except now and then, in a ride to the hills, so that I thank God I have not to reproach myself with any instances of misconduct towards a generous father. . . . Free in mind he read deeply in his beloved classics. Dr. Richard Bentley ${ }^{1}$ increased his library materially by the gift of 'a valuable parcel' of the elder Bentley's books and papers. In letters of Newton, notes for a Pharsalia, and many manuscripts Cumberland found ore well worth the digging. The young man's sensitive nature shrank from the collisions of daily life; it is small wonder that these quiet days at the university pleased in retrospect. His pleasures were

${ }^{1}$ Rector of Nailstone, a nephew of Richard Bentley, Cumberland's grandfather. Doctor Bentley inherited his uncle's library.

2 This 'parcel' included, also, 'a considerable number of Greek and Latin books, mostly collated, [by Richard Bentley, the scholar] and their margins filled with alterations and corrections in his own hand.' 
'those intellectual pure enjoyments, which leave no selfreproach.' 'With the works of my ancestors in my hands,' he writes, 'and the impression of their examples on my heart, I flattered myself in the belief that I was pressing forward ardently and successfully to follow them in their profession, and peradventure not fall far behind them in their fame.'

This leisurely manner of life received a shock in his sudden appointment to an opponency in mathematics, ${ }^{3}$ and in the realization that he had not yet read a proposition of Euclid. By the aid of a kindly tutor, his name was erased from the act, and, stirred by this warning, he now devoted himself to direct preparation for the degree. His carelessness changed to an unwise zeal. For six months he lived in a kind of insane simplicity, studying constantly, sleeping but six hours, 'living almost entirely upon milk, and using the cold bath very frequently.'

From this mode of life the candidate emerged weakened in health, but a master in the learned sciences. He now waited eagerly for the time when he might 'keep an act,' as the engaging in a college debate was called. The appointment came. Cumberland confidently faced his rival, who proved to be 'a North-country black-bearded philosopher,' famous in the schools, and towering over Cumberland as Goliath above David. The giant, however, sank in the mire of his own Latinity, and Cumberland gained a rather easy conquest. He kept, in all, two acts and two first opponencies with credit. During the

${ }^{3}$ It was thus Cumberland's duty to be an opponent in an academical disputation for a degree, a part for which, on account of lack of definite study, he was unfitted. The 'act,' which was formerly a thesis publicly maintained by a candidate for a degree, survives now at Cambridge in the name given the thesis and examination for the doctor's degree in divinity, law, and medicine. 
last of these, his health gave way, and he fell desperately ill. After six months of trembling on the brink of death, came a gradual recovery, hastened by the news that he had attained high rank among The $W$ ranglers. ${ }^{4}$ The episode is an early instance of Cumberland's industry and tenacity of purpose.

Upon his return to college, Cumberland took the deferred degree of Bachelor of Arts. He found that the triumphs of the previous term had won him a position of ease and credit in the university. His experience in college had been almost wholly intellectual, and his achievements in classroom and lecture hall had given him a faith in the English university system which persisted until the end of his life. 'I would,' he says, 'most earnestly impress upon the attention of my reader the extreme usefulness of these academical exercises, and the studies appertaining to them, by which I consider all the purposes of an university education are completed; and so convinced am I of this, that I can hardly allow myself to call that an education, of which they do not make a part. . . What more can any system of education hold out to those, who are the objects of it, than public honors to distinguish merit, public exercises to awaken emulation, and public examinations, which cannot be passed without extorting some exertion even from the indolent . . . ?' Cumberland's ideas upon education are cleverly set forth in The Observer, a descendant of The Spectator, which he published in 1785 . Geminus and Gemellus, having had educations based, respectively, upon the private and public systems, after some years meet. 'The contrast,' says

4 In Cumberland's time The Wranglers were what their name suggests: men who had proved their power in public disputation, rather than as today, the first class in the elementary division of the public examination in pure and mixed mathematics. 
The Observer, 'which this meeting exhibited, spoke in stronger terms than language can supply, the decided preference of a public and liberal system of education, to the narrow maxims of private and domestic tuition. On Gemellus's part all was candour, openness and cordiality; he hoped all childish differences were forgiven. . . . On the side of Geminus there was some acting, and some nature; but both were specimens of the worst sort; hypocrisy played his part but awkwardly, and nature gave a sorry sample of her performances.'

There is an unpleasant dryness about this period of Cumberland's life. There exists no hint of a time of storm and stress which has tried so many great natures, no suggestion of doubt, of the anxious choice of vocation. His was a nature seeking instinctively a life of quiet, of retirement from the world, and asking no great rewards from those without the walls of his college. The main problems of his life were solved. Up to this time, no career other than that of the church had occurred to him, and his immediate plan was for three years of study, culminating in a fellowship and the degree of Master of Arts. 'These views,' writes Cumberland, 'so suited to my natural disposition, were now before me, and I dwelt upon them with entire content.' But far other than studious ease was concealed in the lap of the gods.

Before, however, the unexpected was made known, new literary adventures befell Cumberland, all expressions, perhaps, of his deepest life experience, the striving for intellectual achievement. The first venture was a Collectanea of his studies, containing all data relative to the Boyle-Bentley controversy, while the second, a boyish

5 The Observer, No. 37. 
dream, attempted no less than an Universal History. ${ }^{6}$ The ardour of this flight was chilled by a glance at the Oriental languages, far beyond the young historian, and the cosmic work dwindled to a Review of the Systems of the Heathen Philosophers. A third and more significant effort was the writing of a Greek tragedy. In $175^{2}$ William Mason had published his Elfrida, and Cumberland, sharing the general admiration, composed his drama, Charactacus [sic], written under Mason's influence, and containing a chorus of Bards and Druids, with odes "in the manner of Elfrida." These works were not printed.

Cumberland's health was still unsteady, and a journey to York was suggested by his father. Here he vainly tried the art of idling, and passed a miserable half-year in attempting to enliven his rather heavy talents to please a frivolous household. Some of the disgust of the serious student, dragged into the light against his will, is reflected in the Memoirs: 'The style of living in this place was so new to me and out of character, when contrasted by the habits of study and retirement, which I had been accustomed to, that it seemed to enfeeble and depress that portion of genius which nature had endowed me with; I hunted in the mornings, dariced in the evenings, and devoted but a small portion of my time to anything that deserved the name of study.'

In sheer discomfort Cumberland flew to his book and pen, to compose elegies aftẹr the manner of Harımond, ${ }^{8}$

6 This material was used later in a verse composition.

7 See James Smith, Comic Miscellanies, 2.174.

8 James Hammond, the poet, who is said to have died of love for Kitty Dashwood, the friend of Lady Bute. His verses were entitled: 'Love Elegies by Mr. H-nd. Written in the year 1730.' Johnson declared that the poems had 'neither passion, nature, nor manners.' 
and to imitate Spenser. This last indulgence Cumberland counted hardly less than a vice, for he says apologetically: 'I had no books of my own, and unfortunately got engaged with Spenser's Fairy Queen, in imitation of which I began to string nonsensical stanzas to the same rhyming kind of measure. Though I trust I should not have surrendered myself for any length of time to this jingling stream of obsolete versification, yet I am indebted to my mother for the seasonable contempt she threw upon my imitations, felt the force of her reproof, and laid the Fairy Queen upon its shelf.' So fortune was balked in every effort to lighten a mind already far too serious and self-conscious. The essentially introspective cast of this mind is plain from Cumberland's own account of the vacation at York: 'Tranquility not dissipation, or what is called amusement, was the restorative I most needed. The allurements of public assemblies and the society of those, who resort to them, form so great a contrast to the occupations of a student, that instead of being enlivened by the change, I felt a lassitude of mind, that put me out of humour with myself, and damped that ardent spirit of acquirement, which in my nature seemed to have been its ruling passion.'

Soon after his return to Cambridge, Cumberland received a flattering intimation that he would be eligible for his fellowship a year earlier than he had anticipated. While sick with apprehension at competing before the deepest mathematician in England, then master of Trinity College, his anxiety suddenly vanished before a greater problem. This was the offer of a position as private secretary to Lord Halifax. To all but the diffident young man this opportunity seemed a call to success. A refusal was unthinkable. But the prize 
debater, the projector of the Universal History, 'with a head filled with Greek,' did not yearn for the world of men. Self-centered by temperament, he was averse to the complaisance which the new situation demanded. 'I was,' he says, 'not fitted for dependence; my nature was repugnant to it; I was most unfortunately formed with feelings, that could ill endure the assumed importance of some, or submit to take advantage of the weakness of others.' For a short time he halted with reluctant feet at the cross-roads. He was choosing, although he did not know it, between Cumberland, the scholar, and 'Cumberland, the dramatist.' In the end he took the secretaryship, probably with the secret thought that all his bridges were not burned. He could still be a candidate for the fellowship.

At this time Lord Halifax was a figure of force and promise in England. Possessed of an engaging personality, of unusual powers of scholarship, and of a clear insight into the practical affairs of men, his success seemed assured. Cumberland recognized these qualities, but admired more, perhaps, his knowledge of Horace. He observes, however, that the Earl had an hereditary weakness for Prior, and that he declaimed from this poet in the manner of Quin-sins almost equal to the writing of Spenserian stanzas! Cumberland saw Halifax in the prime of his career. 'In the Lord of the house,' he found 'a man regular in his duties, temperate in his habits,' and ruled by a genuine love for a 'woman, in whom no fault or even foible could be discovered, mild, prudent, unpretending.' The only other grown member of the little circle was His Lordship's tutor, Doctor Crane, 'a man of a clear head and a cold heart.'

Cumberland's life became a series of impressions of the 
great world. Since his actual duties to his patron consisted in copying a few private letters, there was ample leisure for curious observation. The empty politeness of the nobility puzzled him, though he could not help admiring the Earl's pre-eminence in these graces; and the ready tongues of the hangers-on filled him with disgusted wonder: 'In the world, which I now belonged to, I heard very little, except now and then a quotation from Lord Halifax, that in any degree interested me; there were talkers, however, who would take possession of a subject as a highwayman does of a purse, without knowing what it contained, or caring whom it belonged to ; many of these gentlemen had doubtless found that ignorance had been no obstacle to their advancement, and now they seemed resolved it should be no bar to their assurance. I found there was a polite as well as a political glossary, which involved mysteries less obscure than those, which are couched under the hieroglyphics of Egypt.' We may believe that Cumberland's political vocabulary was light, for, after waiting two hours for an audience with the Duke of Newcastle, he was dismissed in two minutes, while His Grace washed his hands.

The sharpest nettle of all to the Cambridge student was John Pownall. Halifax was president of the Board of Trade, and John Pownall, the brother of 'Governor Pownall,' was then secretary. On Cumberland's arrival in London, Halifax had taken lodgings for him near Pownall's in Downing Street. The 'sub-secretary,' to use Cumberland's own contemptuous term, was directed to instruct him in his new duties. This he was unable to do without irritating every fibre in Cumberland's body. Fifty years later he sneers at Pownall's mimicry of Halifax: 'When it was my chance to dine at our boarding- 
house table with the afore-mentioned sub-secretary, I contemplated with surprise the importance of his air, and the dignity that seemed attached to his official situation. The good woman of the house, who was at once our provider and our president, regularly addressed him by the name of statesman, and in her distribution of the joint shewed something more than an impartial attention to his plate. If he knew any state-secrets, I will do him the justice to say that he never disclosed them; and if he talked with ministers and great nobles as he talked of them, I will venture to say he was extremely familiar with them.'

The family of Lord Halifax would have seemed to many an asset to a successful career. 'How many young men at my time of life,' says Cumberland, 'would have embraced this situation with rapture!' Yet he himself accepted the opportunity indifferently and, when the time came, relinquished it without deep regret.

At the first opportunity Cumberland hurried to Cambridge where his treasure lay. Among his rivals for the coveted fellowship were Spencer Madan, later Bishop of Peterborough, and John Higgs, a life-long friend. Sterne's Uncle Toby and Trim never discussed bastion and counterscarp so hotly as does Cumberland the technique of this battle between master and candidate. Once again in the classroom the diffident youth becomes Cumberland, the warrior, armed to the teeth with his own Universal History. After a grilling from many masters, for a final ordeal, Cumberland was directed to turn into Latin or English verse a confusing array of Greek sentences. The place assigned for this task chanced to be the master's lodge, the very room where he had been born, and his Latin verse contained a happy admixture of 
reminiscence. On the next day he was awarded the fellowship.

'Having staid,' Cumberland writes, 'as long in college as in gratitude and propriety I conceived it right to stay, I went home to Stanwick, and from thence paid my duty in a short visit to Lord Halifax.' In this casual record of change of scene, Cumberland's ties are placed in their proper order. At heart he longed for a secluded and studious life at the university, and there is evidence that at times he deeply regretted his decision in favour of the political world. Even now a return to Cambridge seemed not unlikely, since he writes: 'This was certainly a moment, of which I could have availed myself for returning into the line of life, which I had stept out of, and as neither now, nor in any day of my long attendance upon Lord Halifax, there ever was an hour, when my father would not have lent a ready ear to my appeal, the reasons, that prevailed with me for persisting, were not dictated by him.' If not dictated, they were probably inspired by Denison Cumberland, for desire to exalt the family name was certainly the motive behind so great a sacrifice of inclination.

The mutual devotion of the family and Richard defied separation. Actually he never left Stanwick, for, throughout the years in London, a constant interchange of visits and letters persisted, and his holidays were divided between his father's home and that of the kindly Ambrose Isted of Ecton. ${ }^{9} \quad$ About I 754 came a proof of paternal devotion. With the sole purpose of being nearer his son, Archdeacon Cumberland changed his living at Stanwick for one at Fulham. 'Nothing,' says the autobiog-

${ }^{9}$ Other friends in the neighborhood were the Ekins brothers, and Richard Reynolds. Cumberland was, at one time, in love with Reynolds's sister. See Memoirs, 1.167-8. 
rapher, 'could have prevailed with my father for leaving those, whom he had so long loved and cherished as his flock, but the generous motive of giving me an asylum in the bosom of my family.'

Meanwhile Cumberland's portion in life was lonely study. His quiet lodging in Mount Street bade defiance to the whir of the city, and, immured by books, he lived the life of high contemplation. Writing employed his leisure hours, and he again tried his hand at verse, composing a 'Church-yard Elegy, written on St. Mark's eve.' 'A plaintive ditty,' he rightly calls it, and it has little significance except as the author's first printed composition. Much time was spent in writing an epic poem based on the materials of the History of India. No better proof of Cumberland's lack of poetic genius can be found than in the excerpts from this poem, contained in the Memoirs. ${ }^{10}$ His time for creative writing had not yet come.

Cumberland's contact with the fashionable world was not all unpleasant or unprofitable. Lord Halifax gave him little to do, and he spent many hours in observing the literary and political gods of the time. The Memoirs, consequently, abounds in silhouettes of the age. None

$10 \mathrm{~A}$ few typical lines of this youthful poem are subjoined. The excerpt celebrates the conquests of the Portuguese:

In India now

From th' hither Tropic to the Southern Cape

Show'd to the setting sun a shore of blood:

In vain her monarchs from a hundred thrones

Sounded the arbitrary word for war;

In vain whole cataracts of dusky slaves

Pour'd on the coast: earth trembled with the weight;

But what can slaves? What can the nerveless arm,

Shrunk by that soft emasculating clime,

What the weak dart against the mailed breast

Of Europe's martial son? 
is more clear-cut than the description of that extraordinary personage, George Bubb Dodington. The eccentric Maecenas was then at the height of his picturesque career. Bufo, in Pope's Epistle to Dr. Arbuthnot, had enhanced the literary associations of his name, and he had been the object of numerous addresses and dedications-among others Young's Third Satire, Fielding's Epistle On True Greatness, and Thomson's Summer.

La Trappe, one of the eccentric's many abodes, was at Hammersmith, a scant mile from Fulham, and Dodington had called courteously at the parsonage. Cumberland was not slow to perceive the opportunity of observing at close range this unique character, and frequently passed the curious pebble crest which marked the entrance to La Trappe. Here Cumberland met Glover, the author of Leonidas, and, later, Samuel Foote and Arthur Murphy. Since, for political purposes, Halifax was exceedingly desirous of linking Dodington by every possible chain, he eagerly encouraged Cumberland's cultivation of Dodington's friendship, and, as this progressed easily, Cumberland soon made one of parties at the Eastbury mansion, and at the town house in PallMall. The rival glories of the places dazzled his student eyes. In the villa were 'two rows of antique marble statues ranged in a gallery floored with the rarest marbles, and enriched with columns of granite and lapis lazuli; his saloon was hung with the finest Gobelin tapestry, and [Dodington] slept in a bed encanopied with peacocks' feathers in the style of Mrs. Montague.' The mansion at Eastbury had been built by Vanbrugh, after the model of Blenheim, but, unfortunately, the rooms exhibited 'a profusion of finery, that kept no terms with simplicity, and not always with elegance or harmony of 
style.' In brief, good taste was lacking in all of Dodington's furnishings. 'I recollect,' says Cumberland, 'his saying to me one day in his great saloon at Eastbury, that if he had half a score pictures of a thousand pounds apiece, he would gladly decorate his walls with them, in place of which I am sorry to say he had stuck up immense patches of gilt leather shaped into bugle horns upon hangings of rich crimson velvet, and round his state bed he displayed a carpeting of gold and silver embroidery, which too glaringly betrayed its derivation from coat, waist coat and breeches by the testimony of pockets, button-holes and loops with other equally incontrovertible witnesses, sub-poena'd from the tailor's shopboard.'

Dodington's dress compelled attention: 'He had a wardrobe loaded with rich and flaring suits, each in itself a load to the wearer. . . . His bulk and corpulency gave full display to a vast expanse and profusion of brocade and embroidery, and this, when set.off with an enormous tye-perriwig and deep laced ruffles, gave the picture of an ancient courtier in his gala habit, or Quin in his stage dress.'

So much for the setting. Cumberland's picture of the man himself has the touch of the master. Surrounded by a motley group of outworn wits, Dodington 'made music of them all.' Cumberland remarks upon the exceeding quickness and vividness of his mind, his sycophancy towards Walpole, Chesterfield, and Fox, and his daring mockery of William Beckford. ${ }^{11}$ It is easy to imagine the over-confident alderman writhing under well-

11 Walpole, however, boasted that he 'got $£ 5000$ from [Dodington] which he will never see again.' Chesterfield ousted him from the favour of the Prince of Wales; and Dodington was subordinate to Fox as treasurer of the navy. 'Alderman Beckford,' as Cumberland calls him, became Lord Mayor of London on October 29, 1762. 
placed shots, and 'Dodington lolling in his chair in perfect apathy and self-command, dosing and even snoring at intervals in his lethargic way,' and breaking out 'every now and then into such gleams and flashes of wit and irony, as by the contrast of his phlegm with the other's impetuosity, made his humour irresistible, and set the table in a roar.' Though Cumberland says that Dodington had a serious side, and tells us that he was never 'flippant upon sacred subjects,' nor cared for 'the trivial amusement of cards,' posterity is apt to smile doubtfully. We prefer to think of him reading Jonathan Wild to the Ladies Stafford and Hervey, or acting the whimsical rôle of Cleopatra's clown.

Cumberland is seemingly overlooked by Dodington in the famous Diary, and Lord Melcombe's opinion of him must remain unknown. Cumberland was, however, intimate enough to express frankly his disapproval of the Diary. 'I was,' he says, 'acquainted with his diary, which since his death has been published, and I well remember the temporary disgust he seemed to take, when upon his asking what I would do with it, should he bequeath it to my discretion, I instantly replied, "that I would destroy it." ' Some political verses by the young man, eulogistic of Lord Halifax, were read aloud one evening by Dodington. 'I was not present,' says their author, 'as may well be conceived, at this reading, but I confess I sate listening in the next room, and was not a little gratified by what I overheard.' Cumberland's part, as a friend of Lord Halifax, must have been the privileged observer's.

On his twenty-seventh birthday Cumberland was married to Miss Elizabeth Ridge, ${ }^{12}$ the daughter of George

12 For impressions of Mrs. Cumberland see Private Correspondence of David Garrick, 1.425, Mudford, Life of Cumberland, 580-81; Diary and 
Ridge, ${ }^{13}$ of Kilmiston. The two families thus joined were distantly related, and for many years had lived on terms of intimacy. The first London home of the couple was in Duke Street, Westminster. Little information concerning Mrs. Cumberland is obtainable either through her husband's Memoirs, or through other sources. This was a happy marriage.

With the accession of George the Third in 1760 and the rise of Bute, Halifax was chosen Lord-Lieutenant of Ireland. William Gerard Hamilton was chief secretary, and Cumberland was made Ulster secretary. Halifax began his duties in Ireland in October, I76I, and Cumberland attended him in his new capacity.

Cumberland was now at the outset of broadening years. Suddenly thrown into the very midst of Dublin's political and social life, he eagerly watched each great figure. Here he caught his first glimpse of Edmund Burke, who 'had . . . his fortune to make,' but who 'was not disposed to make it by any means but such as perfectly accorded with his feelings and his honour.' Here Cumberland saw 'Single-speech Hamilton,' the 'indefatigable, meditative, mysterious'; and here his amazed eyes beheld Clement's 'Parisian luxury' set down in the very hodge-podge of Dublin society. Before Primate Stone he stood abashed. This was a strong man, one 'formed to hold command over turbulent spirits in tempestuous seasons.' Yet he found him a leader 'in every

Letters of Fanny Burney, Dobson ed., 1.282, 286, 288, 289; The Cumberland Letters, 160.

13 George Ridge was hated cordially by Dr. J. Hoadley, the friend of Garrick. In letters to Garrick on May 22 and 28, 1772, Doctor Hoadley relates the misdemeanors of Mr. Ridge. But 'let,' he says, 'my scandal fall upon the right horse, and the good Cumberlands live in peace and reputation, and go on to divert and improve the world.' Private Correspondence of David Garrick, 1.466, 470. 
character seen to more advantage than in that, which according to his sacred function should have been his chief and only object to sustain.' Cumberland frequented the taverns, the theatres, and the houses of the great. He saw the 'graceful, genteel and spirited' Barry, ${ }^{14}$ then Mrs. Dancer at the Crow-Street Theatre, and discovered that 'the spirit of conviviality was by no means excluded from the pale of the church of Ireland.'

The personality of George Faulkner ${ }^{15}$ sank deep into Cumberland's memory. 'The prince of Dublin printers,' and the prince of good livers was then over sixty, but at the very top of his powers of wit and digestion. Since even the mimicry of Foote inadequately portrayed Faulkner, the pen of Cumberland can hardly do justice to his 'perfect buffoonery.' 'I sate at his table,' says the latter, 'from dinner till two in the morning, whilst George swallowed immense potations with one solitary sodden strawberry at the bottom of the glass, which he said was recommended to him by his doctor for its cooling properties.' Laughter shook the company while Faulkner poured forth story after story of Dean Swift, or swore to the beauty of Mrs. Faulkner, who was, in reality, a paragon of ugliness. Battles of lying between Foote and Faulkner were not infrequent. 'The host,' writes Cumberland, 'took credit to himself for a few deviations in point of gallantry, and asserted that he broke his leg in flying from the fury of an enraged husband, whilst Foote constantly maintained that he fell down an area with a tray of meat upon his shoulder, when he was

14 Mrs. Barry was considered 'the equal of Mrs. Woffington and Mrs. Cibber in tragedy, and to have surpassed both in comedy.' She later acted the rôle of Evanthe in Cumberland's Timon of Athens.

15 George Faulkner pirated Cumberland's first printed play, The Banishment of Cicero. See Mudford, Life of Cumberland, 132. 
journeyman to a butler.' Cumberland says that when an alderman he grew serious and sentimental, but such a charge seems too gross for one who died some ten years later of overeating.

Cumberland's credit with Halifax had increased yearly. This nobleman, though markedly able, lacked moral depth. The death, in 1753 , of his wife, whom he sincerely loved, plunged him into passionate grief, but enlarged his bent for free living, and he is written today as one whose life was clouded by his own folly. At the time of the departure for Ireland, Cumberland had entire charge of the Lord-Lieutenant's finances, and was, to some degree, in his private counsels. He beheld the brilliance of his beginning in Ireland, his high-minded giving, and at last, his farewell. 'The shore was thronged with crowds of people, that followed him to the water's edge, and the sea was in a manner covered with boats and vessels, that accompanied the yacht through the bay, studious to pay to their popular chief governor every valedictory honour, that their zeal and attention could devise.'

Cumberland's uprightness kept off all except clean wages, so that his welfare hung upon the mood of his patron. Since his family was now increased, he was strongly in need of a substantial reward for the ten years' service, and his surprise overcame his pleasure when Halifax suddenly named a baronetcy. 'A mere mouthful of moonshine,' said Ambrose Isted contemptuously. This 'gaudy and insubstantial' offer Cumberland, after due thought, refused. Whatever the reason for it, the refusal was a mistake. Cumberland's regrets were quick, .and are not quite honest enough to make pleasant reading: 'I signified to Lord Halifax,' he says, 'my wish to 
decline the honour he had been pleased to offer me: I certainly did not make my court to him by this refusal, and vanity, if I had listened to it, would in this instance have taught me better policy, but to err on the side of moderation and humility is an error, that ought not to be repented of.'

Although the inner cause is a mystery, from this time Cumberland's hold upon Halifax weakened. There are possibilities of which the autobiographer does not speak. To the noble lord a shrug of the shoulders might seem fair treatment for a man who spurned a baronetcy. Perhaps Halifax was weary of Richard Cumberland. But a sounder judgment lets us think that Cumberland's angry innuendoes were founded on truth. 'In fact,' he says, 'I plainly saw it was not for me to expect any lasting tenure in the share I then possessed of favour, unless I kept it up by sacrifices I was determined not to make; in short I had not that worldly wisdom, which could prevail with me to pay my homage in that quarter, from which my patron derived his ruin, and purchase by disgraceful attentions a continuance of that claim to his protection and regard, which I had earned by long and faithful services for ten years past.'

Halifax's passion for Mary Anne Faulkner ${ }^{16}$ had, indeed, taken leave of all shame. Her reputation as a placemonger was notorious, and Cumberland may easily have been blacklisted to make room for a favourite. Whether this lady, or Halifax himself, was the author

16 Mary Anne Faulkner was the niece of George Faulkner, the Dublin printer. A singer at Drury Lane, she became governess for Halifax's daughter, and later his mistress. On her account he broke off a marriage with the heiress of Sir Thomas Drury of Northamptonshire, an incident which caused the story that 'the hundreds of Drury have got the better of the thousands of Drury.' 
of the discord, it became a certainty that this period of Cumberland's life was drawing to a close. Halifax's last act of kindness to the family was the promotion of Denison Cumberland to the bishopric of Clonfert. The Lord's appointment to the office of Secretary of State took place in October, 1762 , and the blow fell in the appointment to the secretaryship of a Mr. Sedgewicke, a gentlemen who had been his Master of Horse in Ireland, and subordinate to Cumberland. In the story of his first failure, Cumberland's pride winces: 'I could not,' he says, 'be said to suffer any disappointment on the occasion of this gentleman's promotion.' Common sense, however, tells his reader that the end of his political career was passing bitter to him. For it was always Cumberland's hapless fate to lay bare a wound, when seeking with fumbling fingers to conceal it. 'He was,' the first secretary writes with ignoble warmth concerning Sedgewicke, 'a civil, mannerly, and, as far as suited him, an obsequious little gentleman; fond of business, and very busy in it, be it what it might. . . . He well knew how to follow up preferment to its source, and though the waters of that spring were not very pure, he drank devoutly at the fountain head, and was rewarded for his perseverance.'

Halifax's curt rebuff left Cumberland in bad straits. 'After above eleven years attendance,' he declares, with some show of grief, 'my profit was the sole attainment of a place of two hundred pounds per annum, my loss was that of the expence I had put my father to for my support and maintenance in a style of life very different from that in which I was found.' Need brought him to take the humiliating step of applying for Sedgewicke's former place of Master of Horse. It was refused. At 
last, he got from the Earl of Hillsborough a secretaryship which gave him nominal employment. Such was the price of a wrong step in the political world.

An excellent picture in verse of Cumberland's opinion of Lord Halifax may be found in Retrospection, published towards the end of the dramatist's life:

When in a luckless hour I threw aside

My college gown, and Halifax was pleas'd

To call me to his confidence, methought

Form more engaging never grac'd a court

Aspiring elegant, with genius fraught,

A patron better fitted to attract

My admiration than engage my love:

Meanwhile of this sage minister I saw

As much as my humility desir'd

And knew as much as small men know of great.

If more I were to tell, 'twould only prove

The sun that rises clear may set in clouds. 


\section{CHAPTER III}

\section{EARLY DRAMATIC EFFORTS}

THE parting from Halifax, in 1762 , marks the beginning of a new life for Richard Cumberland. The rôle of a political dependant was past; he was to become a writer of plays. A logical date for the beginning of Cumberland's dramatic career is $176 \mathrm{r}$. In this year was published at Charing Cross, at the press of Mr. J. Walter The Banishment of Cicero, a classical tragedy.

The tragedy deals with the conspiracy of Clodius, Piso, and Gabinius against Cicero, and with the latter's escape from his enemies. An unwieldy underplot is concerned with the guilty love of Clodia, and the mutual devotion of Tullia and Frugi.

Cumberland's interest in Tully's life as a subject for the drama had been awakened by a reading of Middleton's Life of Cicero, then newly published. That Cumberland recognized the limitations of his play is clear, for he says: 'As the hero of a drama I was not happy in my choice of Cicero, and banishment is a tame incident to depend upon for the interest and catastrophe of a tragic plot.' But even a classical tragedy was a beginning in dramatic composition, and the play occasioned Cumberland's first meeting with David Garrick.

For Lord Halifax, who had read The Banishment of Cicero, determined to secure Garrick's judgment upon the tragedy. He accordingly introduced his protégé to Garrick, who was then at Hampton, and left the manuscript for the actor's inspection. Cumberland's hopes 
of a favourable reply were not high. Garrick took the play, he says, 'with all possible respect and promised an attentive perusal, but those tell-tale features, so miraculously gifted in the art of assumed emotions, could not mask their real ones, and I predicted to Lord Halifax, as we returned to the lodge, that I had no expectation of my play being accepted.' The author's misgivings were well founded, and the play was never staged. Garrick 'returned the manuscript to Lord Halifax with many apologies to his Lordship, and some few gratifying words to its author.'

Dibdin, after condemning certain offensive scenes in the play, confirms Garrick's judgment: 'It was, in fact, though strongly written in many parts, evidently an inexperienced production, and therefore, the manager, in refusing it, did his duty by the public.' ${ }^{1}$ Biographia Dramatica, reviewing the play at length, finds the unpleasant scenes 'too vicious and shocking to come within the decent clothing of the tragic muse.' ${ }^{2}$ The character of Clodius is regarded as indefensible and fictitious; the expectations of the reader are misled; Cicero himself is too faintly sketched; and the catastrophe is brought on with too little preparation. Cumberland sought comfort in a letter from Bishop Warburton. 'Let me thank you,' wrote the prelate, 'for the sight of a very fine Dramatic Poem. It is,' said this eulogist, 'much too good for a prostitute stage.'

The rejection of The Banishment of Cicero brought Cumberland to his senses. When the arbiter of public taste, Garrick, so openly 'stated his despair of accommodating a play on such a plan to the purposes of the stage,'

${ }^{1}$ A Complete History of the Stage, 5.285-6. Dibdin gives 1761 as the date of composition of the play.

2 Biographia Dramatica, 3.47. See also Genest, 8.390 . 
so ambitious a man as Cumberland could only change his manner of writing. Setting his ideals behind him he turned to musical comedy. In ${ }_{7} 65$ appeared the hastily written Summer's Tale. This play carried in its wake a quarrel with Isaac Bickerstaff, the first in Cumberland's life of dramatic squalls. Bickerstaff's musical comedies had been carrying London by storm. Between I 759 and $177 \mathrm{I}$ he had offered no less than a score of pieces, of which his Love in a Village, acted in 1762 , and Maid of the Mill, of $\mathrm{I}_{765}$, had been notable successes. Mrs. Inchbald considered his genius, in this field, second only to Gay's. If Cumberland did not imitate, he was, at least, strongly influenced by Bickerstaff, and the latter loudly accused him of plagiarism. If Cumberland was stealing, it was from a thief. The Whitehall Evening Post of January 7, 1772, refers to 'the ingenious $\mathrm{Mr}$. Bickerstaff, who with respect to an Air or an Opera, is as good a plagiarist as any of his Majesty's domains.' Bickerstaff resented The Summer's Tale as an intrusion upon his province, and Cumberland says that he 'set all engines of abuse to work upon me and my poor drama, whilst it was yet in rehearsal, not repressing his acrimony till it had been before the public.' Cumberland wrote a letter of remonstrance to his tormentor, who afterwards confessed to Garrick the injustice of his attack.

But Cumberland had various friends in the musical world, who tendered him valuable assistance. Karl Friedrich Abel, the celebrated player on the viola da gamba and composer of instrumental music, wrote the overture for the piece. Thomas Augustine Arne, the regular writer of light music for the London theatres, and Samuel Arnold, the musician of Covent Garden, also lent support; and Johann Sebastian Bach, who had 
come to England in I 762, and had been appointed Music Master to the Royal Family, is possibly the Bach mentioned by Cumberland as another composer eager to lift the piece to the pinnacle of operatic glory. Under such influences The Summer's Tale became, as Cumberland himself said, Vox et praeterea nihil.

'I sate down,' says Cumberland, '. . . and soon produced a thing in three acts, which I named the Summer's Tale.' The author emphasizes his carelessness in composition, and says: 'My friends'-Abel, Bach, Doctor Arne, and Arnold-'who were critics merely in music, took as little concern about revising the drama, as I took pains in writing it; they brought me the music of old songs, and I adapted words to it, and wove them into the piece, as I could.' The Summer's Tale was acted on December 6, I765, at Covent Garden. 'A Musical Comedy in 3 acts,' to use Genest's phrase, 'it was performed without much applause, except what the vocal performers obtained.' 3 Biographia Dramatica remarks upon its cold reception, in spite of its run of nine nights, ${ }^{4}$ and Dibdin, declaring it 'too heavy for a comic opera,' says its music is 'in general dull and ill-chosen.' ${ }^{5}$ But The London Review for December considers Cumberland's lyrics of more poetical merit 'than any . . . since the opera of the Capricious Lovers, ${ }^{\circ}$ a piece by Robert Lloyd. The final verdict may be that The Summer's Tale, in spite of excellent musicians and actors, failed because Cumberland totally lacked ability for this species of dramatic composition.

3 Genest, 5.104.

4 Biographia Dramatica, 4.307.

3 A Complete History of the Stage, 5.286.

- The Capricious Lovers, a comic opera by Robert Lloyd, was acted at Drury Lane Theatre in 1784 ; it had a run of nine nights. 
The reader of The Summer's Tale is at a loss to explain Bickerstaff's uneasiness, and Cumberland's promise to him to write no more musical comedies seems a needless assurance. The author of Love in a Village had nothing to fear from The Summer's Tale.

Cumberland did not yet understand the nature of his own powers. He believed that musical comedy pointed the way to popularity, and was loth to give it up. $\mathrm{He}$ tried, accordingly, to keep The Summer's Tale before an audience. On April I 2, I 768, there appeared at Covent Garden, Amelia, a curtailed form of the earlier comedy, and containing its central episode. 'Before,' says Cumberland, 'I had ushered my melodious nonsense to the audience, I had clearly discovered the weakness of the tame and lifeless fable on which I had founded it.' Accordingly, in revision, he selected the scenes between Henry and Amelia which were 'tolerably conceived,' and constructed 'an after-piece of two acts.' 'Cut down to a farce, . . . it did as little in that form as at first, ${ }^{7}$ declares Dibdin, but Cumberland claims moderate success for it, and, in Genest's opinion, 'it was acted with very tolerable success.'

The importance of The Summer's Tale and Amelia in a study of Cumberland, lies, as Walter Scott has pointed out, in its effect upon the dramatist himself. ${ }^{9}$ It represents a step nearer sentimental comedy. Only through the influence of musical comedy did Cumberland become an apostle of 'legitimate drama.'

7 A Complete History of the Stage, 5.286.

8 Genest, 5.104.

${ }^{9}$ Novels of Swift, Bage and Cumberland. 'Prefatory Memoir to Richard Cumberland,' 40. 


\section{CHAPTER IV}

\section{GARRICK.-THE BROTHERS}

CUMBERLAND was disappointed, but far from discouraged by the failure of his musical pieces. From the year I76I we may think of him as busied constantly with the drama. Returning one day from a rehearsal of The Summer's Tale, he fell in with an old friend, none other than 'Gentleman Smith' of Covent Garden. Smith, whom Churchill epitomized in the Rosciad as 'the genteel, the airy, and the smart,' was a picturesque character of the London playhouses, and an oracle of theatrical wisdom. Even then his Charles Surface was greatly admired, and his Kitely was thought superior to Garrick's. 'He had,' says Cumberland in retrospect, 'the kindness to remonstrate with me upon the business I was engaged in, politely saying, that I ought to turn my talents to compositions of a more independent and a higher character; predicting to me, that I should reap neither fame nor satisfaction in the operatic department, and demanding of me, in a tone of encouragement, why I would not rather aim at writing a good comedy, than dabbling in those sing-song pieces.' Cumberland was quick to see light ahead, and Smith's advice found an immediate response: 'The animating spirit of this friendly remonstrance, and the full persuasion that he had predicted truly of the character and consequences of my undertaking then on foot, made a sensible impression on my mind, and in the warmth of the moment I formed 
my resolution to attempt the arduous project he had pointed out.'

The resolution took its first dramatic form not in a comedy but in an adaptation of a Shakesperian tragedy. Although Cumberland's version of Timon of Athens was not acted until I77I, it was written three years earlier. Its purpose was to conquer David Garrick. He accordingly wrote the dictator telling him that the tragedy had been unjustly rejected by George Colman, and begged him to acept it.

Garrick's perfunctory politeness in return recalls his treatment of The Banishment of Cicero. His letter is dated February 5, I 768, and runs in part: 'I have read "Timon" over very carefully, and think that the alterations have great merit in the writing part, but as they do not add greatly to the pathos of the play, and break into its simplicity, I really believe that the lovers of Shakspeare would condemn us for not giving them Timon as it stands in the original.' ${ }^{\prime}$ Cumberland, in his reply, does not conceal his disappointment, nor his sense of the absurdity of Garrick's pretext, 'simplicity.' 'I shall be glad,' he says angrily, 'to see the time when simplicity is a recommendation to any dramatic piece. It was in conformity to the depravity of modern taste that I altered Shakspeare; and I conceived that, when I robbed him of the beauties of his native simplicity I made him less venerable indeed, but more suitably equipped for the company he was to keep. I hope,' he finishes ironically, 'your ideas are better founded than mine.'2

But on March 21, 1768, Garrick has another letter from the persistent playwright. Cumberland now offers a comedy, "both in plot and execution, entirely new and ${ }_{1}^{1}$ Private Correspondence of David Garrick, 1.284.

2 Ibid., 1.284-5. 
original.' Of Garrick's reply we know only that it was negative. The new comedy must have been The Brothers, later accepted and staged at Covent Garden Theatre. 'It was written,' says the author, 'after my desultory manner, at such short periods of time and leisure, as I could snatch from business or the society of my family, and sometimes even in the midst of both, for I could then form whole scenes in my memory, and afterwards write them down, when opportunity offered; neither was it any interruption, if my children were playing about me in the room.'

The Brothers was acted on December 2, I769. It was a fortunate evening for Cumberland, and may well be regarded as the beginning of his dramatic success. Garrick himself was an interested witness of the play, and Cumberland, 'planted in the back seat of an upper box opposite to where he sate,' anxiously watched for the outcome of a more subtle assault upon the actor's regard. At the close of the play Mrs. Yates ${ }^{3}$ advanced to pronounce the epilogue. Suddenly the actress paused at the lines:

Who but hath seen the celebrated strife Where Reynolds calls the canvas into life, And 'twixt the tragic and the comic muse, Courted of both, and dubious where to chuse, Th' immortal actor stands-?

Cumberland's hopes and fears may be imagined. His eyes were fixed on Garrick. But the 'immortal actor's'

3 Mrs. Yates had established her fame by her performance of Mondane in Arthur Murphy's tragedy, The Orphan of China, acted at Drury Lane April 21, 1759.

4 Sir Joshua Reynolds's portrait of Garrick between the muses of tragedy and comedy. The picture brought three hundred guineas at the Exhibition of 1762, in Spring Gardens. Northcote has a fine description of the colouring. 
pleasure was unmistakable. Fitzherbert, ${ }^{5}$ who had been sitting with Garrick, came across the theatre to tell Cumberland that Garrick 'had been taken by surprise, but was not displeased with the unexpected compliment from an author, with whom he had supposed he did not stand upon the best terms; alluding no doubt to his transaction with Lord Halifax respecting The Banishment of Cicero.' Cumberland's object was attained.

The friendship between Garrick and himself, begun so dramatically, continued until the actor's death. What Cumberland's manuscript plays had failed to accomplish was achieved by a clever epilogue. Garrick's sensibility to skilful flattery was a large element in his recognition of the new dramatist, but it must not be forgotten that The Brothers was successful, and the author of a successful comedy could not be ignored, even by Garrick. Cumberland's delight in his new friend is plain in the Memoirs: 'From this time,' he says complacently, 'Mr. Garrick took pains to cultivate an acquaintance, which he had hitherto neglected, and after Mr. Fitzherbert had brought us together at his house, we interchanged visits, and it is nothing more than natural to confess I was charmed with his company and flattered by his attentions. I had a house in Queen-Anne-Street, and he then lived in Southampton-Street Covent Garden, where I frequently went to him and sometimes accompanied him to his pleasant villa at Hampton.'

The Brothers was moderately successful, and Davies, in his Memoirs of the Life of David Garrick, concedes it a run of twelve nights. Even Horace Walpole, no friend to the average aspiring dramatist, was moved to

5 William Fitzherbert, Commissioner of the Board of Trade, a friend of Garrick's, and a member of the group which met at the British CoffeeHouse. He is mentioned several times by Cumberland. 
remark to George Montagu: 'Mr. Cumberland has produced a comedy called The Brothers. It acts well, but reads ill; though I can distinguish strokes of $\mathrm{Mr}$. Bentley in it. Very few of the characters are marked, and the serious ones have little nature, and the comic ones are rather too much marked; however, the three middle acts diverted me very well.' ${ }^{\circ}$ Montagu's reply is a vivid comment upon Cumberland's fortunes since his parting from Lord Halifax: 'I am glad it succeeds,' he writes, 'as he has a tribe of children, and is almost as extravagant as his uncle, and a much better man."

If Cumberland's epilogue won him one friend, his prologue gained him a hundred enemies. Thomas Davies, the actor and the faithful enemy of Cumberland, describes the situation: 'The author opened his prologue,' says he, "with a brisk attack upon his brother writers, somewhat, I think, inauspiciously; after reproaching them in pretty severe, though trite terms, with gleaning from novels, and picking up offals from every shop and stall, and filching from each periodical work, or magazine; and, after railing at them for stealing the vile refuse of French writers, he boldly promised something of English manufacture.

Not so our bard; to-night, he bids me say,

You shall receive and judge an English play.

From no man's jest he draws felonious praise,

Nor from his neighbor's garden crops his lays. . . .

'If some people were not apt to forget as fast as they read,' continues Davies, 'I should suspect that the author depended upon the want of recollection or discernment in his auditors; for surely the Brothers is beholden to

${ }^{6}$ Letters of Horace Walpole, Toynbee ed., 7.338.

7 Paston, Little Memoirs of the Eighteenth Century, 74. 
more than one English author. . . We have in our English comedies several diverting squabbles between scolding wives and henpeck'd husbands; but the last scene of the fourth act, between Sir Benjamin Dove and his Lady, is apparently an imitation of another very like it in Mr. Colman's Jealous Wife; ${ }^{8}$ the author has not indeed varied it much.'

'It must be confessed,' says Victor in his History of the Theatres of London, 'the Author of this Comedy, who also wrote the Prologue, set out rather injudiciously, by a general attack on all his Brethren of the Sock, as Pirates on the old English Authors, as Dependants on the French Comedies; and, at the same Time, promised a little too much for himself: This, of course, brought on the heaviest censures from his incensed Brethren, who were sure to give him no Quarter. As to the merits of the Comedy, I shall only observe it was performed several Nights, and met with a very favorable Reception from the Public. . . . Tho' there were many Criticisms upon this Comedy, yet the impartial Public had great Hopes of the Author, from the Variety of characters in this Play.' ${ }^{\prime 0}$

This clash with rival authors was the first of a long series of duels with writers and critics in which the odds were all against Cumberland. The so-called dramatic critics of the eighteenth century acknowledged no master and spared no man. Their critiques were impressionistic, unscholarly, and often absurd; their judgments were ill-considered and their language at times grossly abusive. The plays of the illustrious and of the obscure

${ }^{8}$ Colman's Jealous Wife was acted on February 12,1761, at Drury Lane Theatre.

${ }^{9}$ Memoirs of the Life of David Garrick, 2.264.

${ }^{10}$ History of the Theatres of London, 3.166-7. 
were alike censured by the venomed pens of the malicious scribes. Sheridan was condemned as easily as the Rev. William Knapp, and Nemo me impune lacessit was their perennial motto. For these gentlemen Sheridan and Garrick professed a contempt which they did not always feel, while their less hardy brethren, such as Colman or Cumberland, were almost abject in their fear. Why, then, did Cumberland immediately antagonize this unlawful but powerful hierarchy? The answer is difficult, and we can best understand Cumberland's personality when we realize that he could not help it. While painfully sensitive himself to the slightest innuendo, his own careless tongue and pen threatened to leave him no friend. $\mathrm{He}$ had already estranged Bickerstaff, had preserved Garrick's friendship with difficulty, ${ }^{11}$ and now, while his spurs as a dramatist were yet unwon, he incontinently assailed those whose friendship he most needed. What he says in the Memoirs of the attack upon him, shows his naiveté. 'A host,' he says, 'of newspaper-writers fell upon me for the pertness and general satire of that incautious composition, and I found myself assailed from various quarters with unmitigated acrimony. I made no defense, and the only one I had to make would hardly have brought me off, for I could have opposed nothing to their charge against me, but the simple and sincere assertion that I alluded personally to no man, and being little versed in the mock-modesty of modern addresses to the audience, took the old style of prologue for my model, and put a bold countenance upon a bold adventure. Numerous examples were before me of prologues arrogant in the extreme; Johnson abounds in such

11 The record of an early passage of arms with Garrick survives in the letters respecting Cumberland's adaptation of Timon of Athens. 
instances, but I did not advert sufficiently to the change, which time had wrought in the circumstances of the dramatic poet, and how much it behoved him to lower his tone in the hearing of his audience: neither did Smith, who was speaker of the prologue, and an experienced actor, warn me of any danger in the lines he undertook to deliver. In short mine was the error of inexperience.'

The Brothers is a sentimental comedy of the most pronounced type. On an old estate on the coast of Cornwall, with the sound of the ocean and the cries of sailors in our ears, the dramatist shows us the elder of the Belfield brothers living selfishly and wickedly. $\mathrm{He}$ has deserted his wife, Violetta, in Lisbon; he has estranged his brother from Sophia, the younger Belfield's betrothed; he has seduced Lucy; and has driven the family of Philip, her lover, 'to the very brink of the ocean for their habitation and subsistence. ${ }^{12}$ Belfield Junior and his uncle, Captain Ironsides, are wrecked near the cottage of the oppressed family, and with them is Violetta, 'twice shipwrecked, and twice rescued from the jaws of death. ${ }^{13}$ Vengeance hesitates for almost five acts, but alights at last upon Belfield Senior as he is about to wed the reluctant Sophia; the play ends with Belfield's repentance, and the triumph of virtue. The hardened villain with the soft spot of sentimental comedy is dissolved in a storm of remorse: 'I am,' he cries, 'struck to the heart; I cannot support my guilt! I am married to Violetta; save me the confusion of relating it: this dishonourable engagement for ever I renounce; nor will I rest till I have made an atonement to an injured wife. ${ }^{14}$

The Critical Review for December, I769, expresses 12 The Brothers, 2.1, Lucy.

${ }^{13}$ Ibid., 1.1, Belfield Junior.

14 Ibid., 5.2. 
in original fashion what every reader of The Brothers feels, the absence of particular virtues or vices in the play, and its general lack of distinction. 'This play,' says the reviewer, 'though it has not a faultless feature in it, makes a tolerable appearance, like some faces, which recommend themselves by a happy assemblage of parts, which, when examined separately, are rather below mediocrity.' Another review of this month, in The Town and Country Magazine, appraises the comedy fairly when it says: 'The Brothers may . . . upon the whole, be reckoned a tolerable acting comedy, notwithstanding there are many sentiments borrowed in their native garb, and others new dressed.' The December Monthly Review observes that 'the author of this play plumes himself on its being an original. $\mathrm{He}$ is much in the right, for there is nothing, that we know of, like it, among all the comic productions of the English theatre. It hath, however, had a run; and perhaps, not without reason. We have not seen it performed, but, we are told, it does not act amiss; though, most certainly, to use another town phrase, it does not read at all.'

The Brothers owed much of its success to scenic devices and to the atmosphere of the sea in which Cumberland enveloped the play. 'This piece,' says The Universal Magazine for December, I769, 'opens in a very striking and uncommon manner with the representation of a storm and a shipwreck. In the back of the scene appears a stranded vessel, in which we find that Robert Belfield, the younger of the brothers has been shipwrecked on the coast of Cornwall.'

Several characters in The Brothers receive attention in the comments of the day. Against Captain Ironsides, the bluff, good-hearted skipper, Davies levelled his charge 


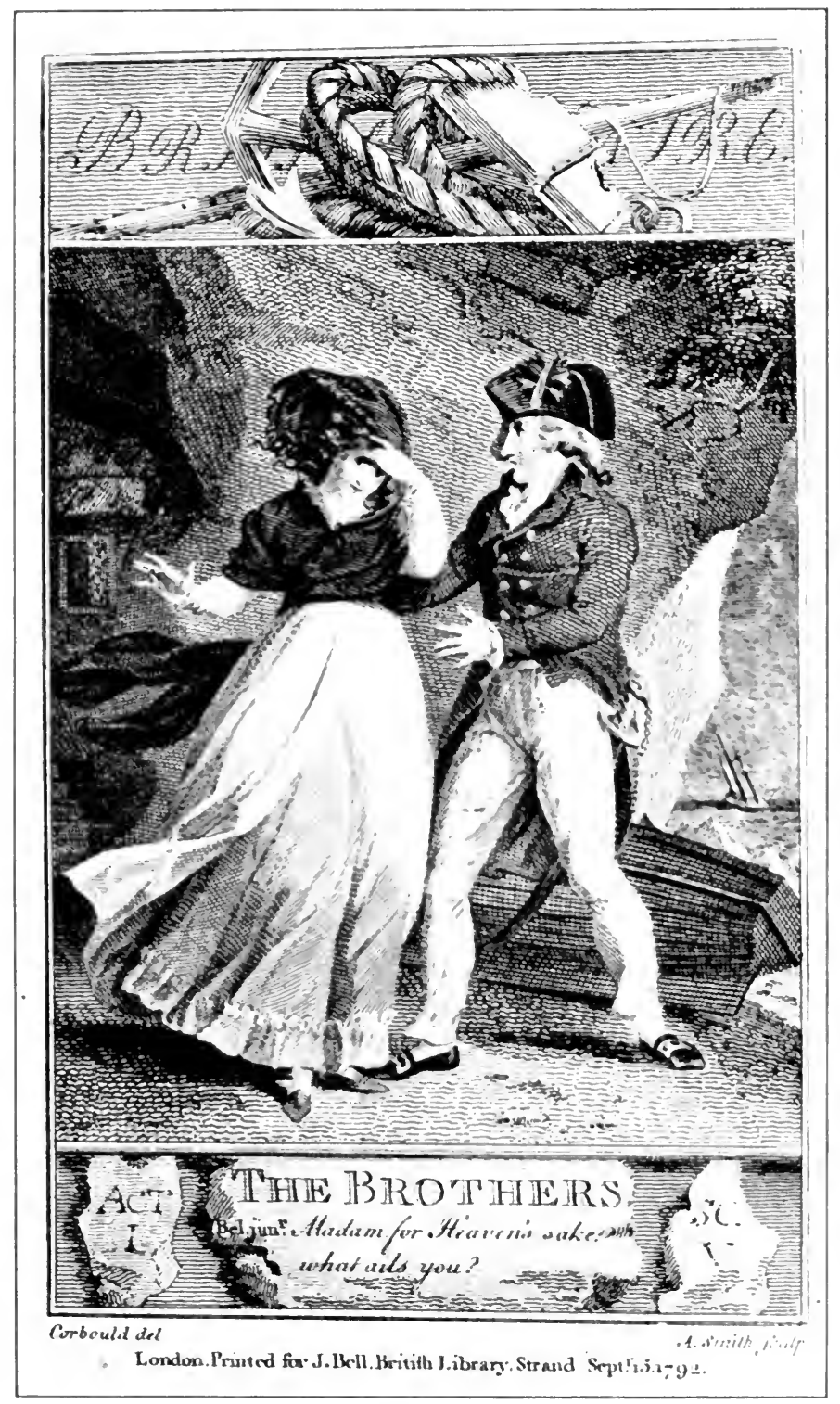



of plagiarism: '. . . Surely, Captain Ironsides is our old friend Ned Bowling dramatically dressed, and taken from a well-known work of Dr. Smollet.' But, he says, 'I see no harm in that; Ned had never trod the stage before, and I was glad to see him make so good a figure upon the theatrical boards.' But The London Review for December gives Ironsides another prototype, saying he is, "with an exception of his unpardonable obscenity only . . . Smollett's Commodore Trunnion or rather Captain Crowe.' The popularity of this character persisted, for on January 16, I778, The London Chronicle says: 'Thursday night Mr. Cumberland's Comedy of "The Brothers" was presented at Covent-garden Theatre, to give Mr. Wilkinson, ${ }^{15}$ of York, an opportunity of appearing in Captain Ironsides.'

The Oxford Magazine for December, 1769, describes the 'very humorous scene between the Knight and young Belfield, in which the former, from an apprehension that his antagonist is a rank coward, draws upon him.' Sir Benjamin's mistaken intrepidity gains him his first real courage: 'You shall excuse me, sir,' he says, 'I have had some difficulty in drawing my sword, and am determined now to try what metal it's made of.' Thus Sir Benjamin Dove becomes a man. Cumberland believed firmly in Sir Benjamin Dove, and says that 'a start of character such as that of the tame Sir Benjamin, is always a striking incident in the construction of a drama, and when a revolution of that sort can be brought about without violence to nature, and for purposes essential to the plot, it is a point of art well worthy the attention and

15 Tate Wilkinson made his first appearance at Drury Lane Theatre on October 17, 1758, and later became a partner in the managership of various theatres in Yorkshire. This performance of The Brothers brought about his reappearance at Covent Garden. 
study of a writer for the stage. I recollect,' he concludes, 'that I borrowed the hint of Sir Benjamin's assumed valour upon being forced into a rencontre from one of the old comedies, and if I conjecture rightly it is The Little French Lawyer.' ${ }^{16}$ Genest calls Sir Benjamin Dove one of the best characters in the play. The London Review, however, thought him reminiscent of Fribble, the coxcomb in Garrick's farce, Miss in her Teens, and of Sir Paul Plyant, the old uxorious knight in Congreve's Double Dealer. $\mathrm{He}$ is, says this reviewer, 'wholly out of nature.'

The other characters of The Brothers received scant notice from the reviewers. 'Andrew Belfield,' protests The London Review for December, 'is too detestable a villain for comedy,' and The Critical Review, from a curious angle, declares that Belfield, 'though a villain, is supposed to be a man of sense, but his conduct proves him a natural fool, in thinking publickly to marry in England a lady of fortune, after having been married in Lisbon, where every transaction of the English is as well known as if it passed in the Royal Exchange at London. $^{17}$ Although Violetta may easily pass as a part of the stage mechanics, The London Review thought her attachment to Belfield after a knowledge of his turpitude 'injurious to the virtue even of a wife.' The same moral critic found that 'Sophia's repeated readiness to marry either of the brothers makes her absolutely despicable.'

The remaining characters are condemned en masse: 'Lady Dove,' says The London Review for December,

16 Beaumont and Fletcher's play, to be found in the Folio of 1647. A version of The Little French Lawyer was acted at Drury Lane in 1749, and another at Covent Garden in $\mathbf{1 7 7 8 .}$

17 The Critical Review, December, 1769. This magazine says that Belfield Junior is a copy of Roderick Random. 
I 769, 'ought not to have been brought before an English audience. As to . . Philip, Goodwin, Jonathan, Francis, the Master of the Privateer, the sailors, Lucy Waters, the maid, and Fanny, they are utterly useless; they indeed, spin out the scenes, but never assist the business, and the poet only makes them talk, when he is entirely at a stand for incident.'

The cast of The Brothers and Cumberland's gossip in the Memoirs indicate the new society with which the dramatist, once the anchorite of Cambridge, found himself familiar. What would now seem a quaint galaxy of histrions gathered about the doors of Covent Garden. Actors of as many kinds as those once catalogued by Hamlet vied with each other in the production of each new play. In the rear of the famous stage self-important tragedians jostled each other, and shrill-voiced actresses declaimed in imitation of the great Clive. The greenroom boasted much, - personality, whimsical humour, and some real worth. Here Cumberland doubtless met and knew Henry Woodward, a comedian of the first rank, who, between 1729 and 1770 , acted most of the great comedy rôles of dramatic literature. Here still acted Richard Yates, the last, with the exception of Macklin, of the old school of acting. His Fondlewife, in The Old Bachelor, has been a model for able actors of Congreve. here, too, were 'Gentleman' Smith, with his air of a university education, 'Dear' Quick, the humorist, and Mrs. Green, 'excellent in the characters of envious ladies and Abigails.' With these Cumberland mingled, and, later, with the clientele of Drury Lane. Small wonder that in later years his knowledge of the stage and of its annals seemed encyclopedic.

George Harris was then manager of Covent Garden. 
Cumberland says that he 'took The Brothers . . . with all its responsibility, supported it and cast it with the best strength of his company. Woodward in the part of Ironsides, and Yates in that of Sir Benjamin Dove, were actors, that could keep their scene alive, if any life was in it: Quick, then a young performer, took the part of Skiff, and my friend Smith, who had prompted me to the undertaking, was the young man of the piece; Mrs. Green performed Lady Dove, and Mrs. Yates was the heroine Sophia.' Walpole testifies to the successful acting of The Brothers. He writes the Countess of Ossory: "There is a new comedy at Covent Garden, called "The Brothers," that has great success, though I am told it is chiefly owing to the actors; an obligation I should not have thought any play would have had to the present actors at either house. ${ }^{18}$

The actors' success centered in the parts of Captain Ironsides and Sir Benjamin Dove. 'Mr. Woodward's Captain Ironsides,' says Davies, 'was a true picture of a brave English tar, ${ }^{19}$ and The Town and Country Magazine for December declares that though Woodward has been accused of throwing in too much of Bobadil in his part, . . . this he has, in some degree, corrected since.' Ironsides was familiar to London audiences for many seasons, and The London Chronicle of January I6, I 770, has a long account of Tate Wilkinson in the rôle. 'His Ironsides,' says the reviewer, 'is rather too much inclined towards the extravagant; the part is here and there touched by the poet with a warmth of colouring which has led this gentleman, and many others, into a conceit, that it borders on the character of Bobadil, and

${ }^{18}$ Letters of Horace Walpole, Toynbee ed., 7.337.

19 Memoirs of the Life of David Garrick, 2.265. 
ought to be thrown into a ridiculous light; whereas the features of the part, in our eye, seem to indicate no more than a blunt, warm-hearted, sea-worn mariner, such a one as Smollet says Capt. Bowling was, or such a one as we know Lord is.

'Mr. Woodward gave this part the same extravagant peculiarity, as the gentleman who played it last night, and at the same time, that their manner is different, the effect in both is the same. It abounds with an infinity of sentimental clap-trap, and they add to the bombast of the poet, the rant of the player.'

The magazines of the day say nothing of the acting of Yates as Sir Benjamin Dove, but an entry in the Journal of G. F. Cooke, the actor, attests the success of this role. 'Dined,' wrote Cooke on September 25, i 802, 'at fourin the evening went to the pit of Drury Lane theatre, to see $\mathrm{Mr}$. Cherry ${ }^{20}$ make his first appearance in London, in the part of Sir Benjamin Dove, in Mr. Cumberland's comedy of "The Brothers"; he was warmly received and applauded, and remarkably well. ${ }^{21}$ Davies says that 'Mrs. Yates condescended to act a very trifling character; Sophia, a young lady supposed to be under twenty.' ${ }^{22}$

Later actors in The Brothers were John Vandemere, the Dublin comedian, James Aikin, Richard Wroughton, Isabella Mattocks, and Mrs. Pope, the heroine of the Irish stage during the last decade of the eighteenth century. The Brothers was frequently revived, and was acted with success in America.

In spite of its many weaknesses, and in spite of the hostile criticism, The Brothers began a new epoch in Bath.

20 'Little Cherry,' a favourite comedian in Dublin, Manchester, and

\footnotetext{
${ }^{21}$ Dunlap, Memoirs of the Life of George Frederick Cooke, 1.262.

22 Memoirs of the Life of David Garrick, 2.264.
} 
Cumberland's life. It was the beginning of his reputation in London; it definitely secured him the friendship of Garrick; and it gave him a strong consciousness of his own powers. From this time he wrote with assurance that he would ultimately attain success. 


\section{CHAPTER V}

\section{THE WEST INDIAN.-DAVID GARRICK}

THE success of The Brothers was, indeed, needed for 1 the very sustenance of the Cumberlands. Although the author does not mention it in his Memoirs, he had held until April, I 768, the office of Provost Marshal of South Carclina. A correspondence with his deputy, which has survived, reveals that the post was not lucrative, but had long promised greater things. In letters to Pinckney he continually urges that the state government purchase his patent. He hopes that 'they will give [him] such a price for it, as shall not leave [him] the least room for hesitation about parting with it; . . . that they will vest as much money in ye English funds, as shall bring me in ye same revenue as my office now produces to me.' The anxious one ends: 'It is superfluous to tell you that this woud be such an access to my large and growing family, such a relief to a father's mind, as woud make my pillow for ye rest of my life easy to me; the thing is too obvious to need explanation.' ${ }^{1}$ But the desired exchange was not effected; hence the joy in the new play's fame.

The letters to Pinckney reflect the great contest then going on for the possession of a continent, and show Cumberland's staunch patriotism. On January I 5,1767 , he writes: 'It was yesterday asserted by the great Mr. $\mathrm{P}-\mathrm{t}$ in the house of Commons, that ye British Parl- $\mathrm{t}$

1 Documents of South Carolina, ed. P. C. J. W., 123-5. 
had no right to tax American Colonies, who were not therin legally represented. It is universally concluded from what past on ye part of Administration in consequence of this gentleman's opinion, that ye Stamp Act will be absolutely revoked and rescinded.' Again in reply to a letter written several years later, manifesting, as Cumberland thought, too much 'zeal for America,' he says: 'You are silent as to your family, and all that concerns a friend and well wisher to hear, but you are very particular in your description of the action at Concord, and the inhumanity of your late countrymen the English troops. . . . I make no reply to the list of savage enormities, ye rapine, plunder, and barbarous indignities to the mangled bodies of ye dead, with which your information loads the military, which in general is composed of the most humane and always of the most brave amongst your countrymen and mine. Time must have cleared up ye truth for you in this particular, even through the medium of New England misrepresentation; and you will now have another account to lament over of the action on the I 7 th of June, in which ye same tale of horror will be repeated, and ye same Tedeums sung by the victorious Bostonians. . . . I deplore the situation of America in every vein of my heart; I think the measures that have inflamed and mislead them have not originated with themselves; they have conceived the idea of disobedience and disorder from the conduct of certain politicians in ye heart of this realm; but the politicians have been opposers and not abettors of administration.'2

At the beginning of 1770 , when Cumberland was not quite forty years old, fortune brightened. His talents, quiet and unobtrusive, were illumined by a new light of

2 Documents of South Carolina, ed. P. C. J. W., 125-6. 
popularity; and powers of scholarship, which were not alone strong enough to rescue him from obscurity, lent distinction to his position as a dramatist. It was felt that when sons of hostlers and inn-keepers wrote successfully for the stage, the grandson of Richard Bentley and Bishop Cumberland should be given at least just recognition. The personnel of English dramatic writers needed the influences of breeding and character. Cumberland was less known as a writer of plays than as a scholar or man of position whose services to the theatre were an adornment to the dramatic profession. He was early distinguished from his fellows as 'the elegant Cumberland.' By the single success of The Brothers were brought into general knowledge his manner of living and his past dramatic ventures. Curiosity concerning the new writer is reflected in The Whitehall Evening Post of December 4, I769. 'Notwithstanding some reports to the contrary,' says the editor, 'we can assure our readers that the new Comedy called The Brothers, is written by

Cumberland; who possesses a considerable post in the Treasury, and is the author of a tragedy called, The Banishment of Cicero, and a musical Comedy, entitled, The Summer's Tale.' Cumberland's own satisfaction must have been supreme. The disappointments, unusually keen to a man of his temperament, of the relinquished university life, and of the failure with Lord Halifax, were now softened. His family was large, his income small, but Mrs. Cumberland's fortune seemed a bar against dire necessity; Cumberland saw before him with not unmoved heart a new and promising way to carry forward the torch of his ancestors.

$\mathrm{He}$ was at once powerfully and weakly equipped to write for the English stage of the eighteenth century. 
He was to experience both brilliant success and humiliating failure; and his unevenness may be traced first and last to strange personality. For dramatic writing he had many talents. His passion for the stage itself was innate and deep seated; he saw plays with enthusiasm and with more than usual insight into their merits and faults; his judgments of actors' abilities were penetrating and sound; and he occasionally acted himself. In addition to these gifts he was possessed of a rare knowledge and command of all previous drama, both ancient and modern. His plays are steeped in scenes and language reminiscent of the masters. What Goldsmith said in jest became sober truth. He was, in reality, 'the Terence of England.' Finally, his ancestry and education, combined with natural sensibility, gave his productions a certain fineness, markedly absent in the work of Kelly, Holcroft, and their kind. However bad, Cumberland's plays are those of a gentleman. But here the catalogue of dramatic virtues ends. Cumberland's learning had been got at the price of knowledge of men. His whole life is a record of trivial irritations and useless enmities. When bound by worshipful admiration, as in the case of Johnson, his envy and emulation were under control, although this modesty was likely to turn into something depressingly near sycophancy. But let there enter the element of competition, and all was lost. What might have been profitable professional friendships were turned to rivalries by the dramatist's petty jealousies. The same disposition which had preferred a cloistered life at Cambridge to one of energy and action under Lord Halifax endured agonies in a life in which no man's tongue was bridled save from fear. Poor Cumberland! With his ideal of scholarly perfection, and his tremulous self- 
esteem, he suffered keenly. The laughter of Colman and Garrick he endured with difficulty, and the malice of Sheridan and of the newspaper critics drove him to madness. He lacked what Garrick rightly considered an essential for a dramatic writer, 'a rhinoceros's hide.'

Garrick was soon to have experience with the gentleman dramatist's personality. We may assume that after the success of The Brothers Cumberland saw much of Garrick, either at his own home in Queen-Anne Street or about London. Early in 1770 , with characteristic industry he is at work upon another tragedy. This play was the ill-fated Salome, later made over into The Arab. He besought Garrick to accept the tragedy, and a letter dated January 25, I770, depicts the relations of the two men. Cumberland is in the dust before the throne. He protests earnestly his acceptance of criticism: 'I am as ready to adopt unfavorable sentiments of my own performance as any man living, and therefore do not allow that we differ in opinion about "Salome." I gave it to you (as I have done every other performance of mine) as the best I could write, but I did not insist upon it that you was to approve of it.' ${ }^{3}$ With characteristic deprecation and equally characteristic persistence, he begs Garrick for an interview, for he has still 'a little partiality left, a small feeling for a performance which has been many years under [his] pen,' and he raps slyly at Garrick's judgment when he adds: 'and which hitherto no friend (not even Mr. Colman himself) has assisted with an objection. I can by no means wish to have any piece put into a performer's hands which a manager disapproves.'

A letter written on March 7 shows, even more clearly, Cumberland's pliant hopefulness. $\mathrm{He}$ is sending Gar-

${ }^{3}$ Private Correspondence of David Garrick, 1.380. 
rick his tragedy, but 'not guided . . . by any other motives than extreme solicitude for [his] judgment.' He declares that 'no labour will deter [him] from giving this every finishing that his pen can give it,' because he wishes to save their 'mutual fame.' The remainder of the letter is too amusingly typical not to be quoted almost entire :

Your objections [he writes] bring so much amendment with them, that if you are not tired of making them, I can never be weary of receiving them. . . . If yet the catastrophe is too shocking, by the danger in which Glaphyra ${ }^{5}$ is kept, I have a plan for softening that, though I am humbly of opinion it has a very great effect as it is. . . I write this to you, Sir, not to puff my performance, but to explain my meaning. Pray keep it, without troubling yourself about an answer, as long as ever you please, and till you have full leisure; for, I should earnestly wish that you did not take it up till you could read it fairly through at one sitting. . . .

Dear Sir, your most obedient and faithful servant,

\section{Richard Cumberland. ${ }^{6}$}

Later Garrick grew tired of the conciliatory, anxious tone. This was evidently the expression of a strong phase of Cumberland's nature, for which the kindliest, if not the truest, name is self-distrust. Now, however, Garrick took him at his real worth, a dramatist of promise, and let the rest go.

It was Cumberland's custom, while living in QueenAnne Street, to pass the summers with his parents in Clonfert, Ireland. Here was Denison Cumberland's bishopric. . In 1770 , in high spirits over the success of

4 Private Correspondence of David Garrick, 1.381.

${ }^{5}$ A character in The Arab.

${ }^{6}$ Private Correspondence of David Garrick, 1.381-2. 
The Brothers, and filled with visions of greater plays, he set out on the annual pilgrimage. Cumberland's prose has seldom been more happy than in this brief account of the passage to Ireland. The letter is written to Garrick from Kildare Street, Dublin, and bears the date of July 4. 'One of the first offices,' he begins, 'following those of duty, is to give myself the importance with you of acquainting you of my safe arrival in this place on the night of the 3 oth instant, after a calm and pleasant voyage of thirty-six hours in a Parksgate ship, which on my arrival I found with her topsails unbent, and ready to catch the first favorable breeze. My dear woman and the little boys, who had been charming companions on board to me, did not lose their spirits by sea; and as I lashed my chariot on deck we sate in it with great state and composure.

Cumberland found the bishop's family in the 'episcopal residence,' a cheerful group in spite of the dreary bog of Clonfert. Material exceeded even spiritual want in the wretched country, and the bishop's hand was everywhere, lightening heavy burdens. By his ministrations poverty became less sordid and more tolerable, and those who had been like beasts became men. 'I was,' writes his devoted son, 'delighted with contemplating a kind of new creation, of which my father was the author.' A practical good from the summers in Ireland lay in the dramatist's study of Irish character. Cumberland was not a psychological observer of character, but he had 'the portrait painting hand.' He thought the Irish savage and licentious, but with 'wild eccentric humours.' 'If,' he says, 'I have been successful in my sketches of the Irish character, it was here I studied it in its purest and most

7 Private Correspondence of David Garrick, 1.425. 
primitive state; from high to low it was now under my view.'

Among the Irish peculiarities which Cumberland remarked were those of Lord Eyre of Eyre Court, a friend of Bishop Clonfert's. This unusual person was the owner of a vast estate, and lived in an elaborate mansion near Clonfert. 'Whilst his table groaned with abundance, the order and the good taste of its arrangements were little thought of: the slaughtered ox was hung up whole, and the hungry servitor supplied himself with his dole of flesh, sliced from off the carcass.' Lord Eyre's manner of life amused Cumberland. 'His Lordship's day was so apportioned as to give the afternoon by much the largest share of it, during which, from an early dinner to the hour of rest, he never left his chair, nor did the claret ever quit the table. This did not produce inebriety, for it was sipping rather than drinking that filled up the time, and this mechanical process of gradually moistening the human clay was carried on with very little aid from conversation, for His Lordship's companions were not very communicative, and fortunately he was not very curious. He lived in an enviable independence as to reading, and of course had no books. Not one of the windows of his castle was made to open, but luckily he had no liking for fresh air, and the consequence may be better conceived than described.'

During this summer at Clonfert, Cumberland wrote The West Indian. Salome seems to have been held in abeyance, but Cumberland was cheered by the success of The Brothers. With his intellectual powers at their best he eagerly set about his task. His affection for his family was always beautiful, and these peaceful days with them made his work easier. The signs of haste and 
distraction so apparent in later plays are lacking in The West Indian. Cumberland's story of the writing of this play reveals his real nature. He says: 'I had none of those incessant avocations, which forever crossed me in the writing of The Brothers, I was master of my time, my mind was free, and I was happy in the society of the dearest friends I had on earth. In parents, sister, wife and children greater blessings no man could enjoy. The calls of office, the cavillings of angry rivals, and the jibings of news-paper critics could not reach me on the banks of the Shannon, where all within doors was love and affection, all without was gratitude and kindness devolved on me through the merits of my father. In no other period of my life have the same happy circumstances combined to cheer me in any of my literary labours.'

Cumberland's study was at the rear of the episcopal palace, and from the window of a small, unfurnished room he had the prospect of a lonely turf-stack, an object which, as he remarks seriously, cannot 'call off the fancy from its pursuits.' In this Irish hut was written a comedy which was to be acted on the English stage for thirty years. 'It was a fortunate room,' says Mrs. Inchbald, 'and if equal success were attached to the spot, it would be worth the pains of a voyage to Ireland, over a stormy sea, with a view to such another composition.' John O'Keeffe, the actor, declares that ' $a$ spot in the garden where [Cumberland] studied was held in great veneration,' and that the owner, out of respect to his memory, never allowed the summer-house to be destroyed.

8 The British Theatre, 18, 'Remarks Prefatory to "The West Indian." ${ }^{9}$ Recollections of the Life of John O'Keeffe, 1.355 . 
Cumberland, moreover, was sustained by the knowledge that he was writing under the eye of Garrick. The friendship had thus far flourished. Garrick had recently cleared Cumberland of a false imputation in the eyes of Edmund Burke; Mrs. Cumberland and Mrs. Garrick were now friends; Cumberland himself had been personal envoy for Garrick, bearing a message to George Faulkner in Dublin. The actor and the dramatist corresponded regularly, and with much friendliness on both sides. It was clear that Garrick, 'ever attentive to varigate the dramatic amusements of the town,'-as the eloquent Town and Country Magazine had it-saw in Cumberland a successful dramatist, and in The West Indian a promising comedy. Did he foresee that it was to be the most popular sentimental drama of the age? Together Garrick and Cumberland worked over The West Indian. 'My acquaintance with Mr. Garrick,' says Cumberland, "had become intimacy between the acting of The Brothers and The West Indian. I resorted to him again and again with the manuscript of my comedy.' On July 2, I $77^{\circ}$, Cumberland wrote Garrick concerning revision of The West Indian. 'I have,' he says in the tone which Garrick later ridiculed, 'had twice the pleasure in following your corrections, that I had in composing the piece; and if your patience does not give out, mine never will.' ${ }^{10}$

In the fall Cumberland returned to England, and the remoulding of The West Indian went on more earnestly than ever. At Hampton Villa, where Garrick dispensed 'true taste, good fare, and good company,' the details of the first night, and the selection of cast were discussed. Garrick, according to his custom, decided all questions of 10 Private Correspondence of David Garrick, 1.387. 
importance. Cumberland depended upon the judgment of his far-sighted friend: 'I took no part in the question,' he says, in regard to the selection of an actor for the part of Major O'Flaherty, 'for I was entitled to no opinion.' Garrick's help in this play, as in others of Cumberland's, was far from academic. He changed scenes, rewrote speeches, and, from his wide experience, made the play better suited to the stage. In the original draft of the drama, Belcour, the mercurial West Indian, enters quietly and unostentatiously. This Garrick changed in characteristic fashion. 'I want,' he said to Cumberland, while they were riding to Hampton, 'something more to be announced of your West Indian before you bring him on the stage to give éclat to his entrance, and rouse the curiosity of the audience; that they may say,-Aye, here he comes with all his colours flying-' So Cumberland writes: 'I entirely adopt your observation on the first scene, and have already executed it in a manner that I hope embraces your ideas.' ${ }^{11}$ Thus the amended play has what Garrick called the 'trumpeters' for Belcour's entrance: the cloud of black servants, the innumerable portmanteaus, and the flock of strange birds. Garrick's knowledge of stagecraft was uncanny, and this was but one of the invaluable lessons learned from him by Cumberland. 'I found in him,' says Cumberland, 'what my inexperience stood in need of, an admirable judge of stage effect.'

As the first night drew near Cumberland feared failure, and desired The West Indian to appear unheralded. 'I could much wish,' he writes Garrick, 'that, if this comedy comes out next season at your theatre, it might steal quietly and silently into the world; there are but

11 Private Correspondence of David Garrick, 1.387. 
two men, yourself excepted, that ever heard a word of it, and they only in part. ${ }^{12}$ The author also desired that the name of the play be concealed, lest the comedy be robbed of its novelty.

Neither of these hopes, if they were sincere, was gratified, and with a liberal sale of seats several nights before the first performance, Cumberland felt his apprehensions rising. He jestingly offered Garrick the proceeds of the play in exchange for a Del Sarto hanging above the actor's chimney-piece, and Garrick, who was all optimism, would have accepted, had not the picture been a gift from Lord Baltimore.

On the first night Cumberland and Garrick, with their ladies, sat in the actor's private box. The author's fears were not diminished when a large body of West Indians, attracted by the name of the play, marched aggressively into the theatre, prepared to resent insults. The opening lines of the prologue were not calculated to soothe these gentlemen:

Critics, hark forward! noble game and new;

A fine West Indian started full in view:

Hot as the soil, the clime which gave him birth,

You'll run him on a burning scent to earth.

So far had Reddish, ${ }^{13}$ the prologist, spoken when a furious uproar interrupted him. 'Garrick,' says Cumberland, 'was much agitated; he observed to me that the appearance of the house, particularly in the pit, was more hostile than he had ever seen it.'

Reddish continued:

12 Private Correspondence of David Garrick, 1.387.

13 Samuel Reddish played important parts at Drury Lane Theatre from 1767 to 1778 . 
That country has no feeble claim, Which swells your commerce, and supports your fame, And in this humble sketch, we hope you'll find Some emanations of a noble mind.

This was more cordial, and wrung tolerance from the suspicious patriots, and the remaining lines won the applause of the Hibernians in the gallery. ${ }^{14}$ The crisis was past, and The West Indian was a success.

'Eight and twenty successive nights,' says Cumberland proudly, 'it went without the buttress of an afterpiece.' 'This Comedy,' so runs Victor's description, 'has fully answered the Expectations of the Public from this improving Dramatic Author. It has unquestioned Merit: -and though when critically compared, not quite equal to some few of our best Comedies, yet the success that has attended the Performance of the West Indian has exceeded that of any Comedy within the Memory of the oldest Man living. There was the same Demand for Places in the Boxes, and the same crowding to get into the Pit and Galleries at the twenty-sixth Representation, as on the first night!'15 The popularity of the play was almost unequalled in the history of sentimental comedy. On February I3, The Whitehall Evening Post writes that 'the new Comedy of the West Indian is still performing at Drury Lane Theatre with great applause,' and on July 26, Richard Burke writes to Garrick from Ireland with some petulance: 'Curse your "West Indian"! I hope the run of it will be over by the time

14 The last lines of the prologue described Major O'Flaherty:

A brave, unthinking, animated rogue,

With here and there a touch upon the brogue;

Laugh, but despise him not, for on his lip

His errors lie; his heart can never trip.

${ }^{15}$ History of the Theatres of London, 3.174. 
I get home. ${ }^{16}$ Cumberland obtained for the copyright $£_{15}$ O, and says that twelve thousand copies of the play were sold.

Perhaps the best picture of the author's happiness in the success of The West Indian is contained in the Memoirs. 'When,' he says, 'Mr. Evans the treasurer came to my house in Queen-Anne-Street in a hackney coach with a huge bag of money, he spread it all in gold upon my table, and seemed to contemplate it with a kind of ecstasy, that was extremely droll; and when I tendered him his customary fee, he peremptorily refused it, saying he had never paid an author so much before, I had fairly earnt it, and he would not lessen it a single shilling, not even his coach hire, and in that humor he departed. He had no sooner left the room than one entered it, who was not quite so scrupulous, but quite as welcome; my beloved wife took twenty guineas from the heap, and instantly bestowed them on the faithful servant, who had attended on our children; a tribute justly due to her unwearied diligence and exemplary conduct.'

Garrick was pleased at the fame of The West Indian, both for the author's sake and for his own. Cumberland's fame was Garrick's. He rejoiced, accordingly, but we find in his contentment a keen sense of the dramatist's peculiarities. Garrick, who, above all others, save, perhaps, Samuel Foote, perceived the ridiculous in his fellows, could not fail to observe in Cumberland the strange compound of pride, diffidence, and self-consciousness. He laughed often at Cumberland, and the laughter sometimes lacked the note of kindliness. Garrick's feelings towards his friend at this time are unconsciously revealed by Cumberland himself in the Memoirs. In

16 Private Correspondence of David Garrick, 1.429. 
spite of his readiness to resent an affront, Cumberland was often singularly obtuse to skilful raillery. On a morning during the run of The West Indian the dramatist called on his patron. That master of mockery had evidently resolved to torment his admirer, but, though he jested recklessly with an unpleasant truth, his words failed to pierce his admirer's armour of vanity, which was now well-nigh invulnerable. Cumberland's account of the interview follows: 'I found him with the St. James's evening paper in his hand, which he began to read with a voice and action of surprise, most admirably counterfeited-"Here, here," he cried, "if your skin is less thick than a rhinoceros's hide, egad, here is that will cut you to the bone. This is a terrible fellow; I wonder who it can be."- $-\mathrm{He}$ began to sing out his libel in a high declamatory tone, with a most comic countenance, and pausing at the end of the first sentence, which seemed to favour his contrivance for a little ingenious tormenting, when he found he had hooked me, he laid down the paper, and began to comment upon the cruelty of newspapers, and moan over me with a great deal of malicious fun and good humour- "Confound these fellows, they spare nobody. I dare say this is Bickerstaff again; but you don't mind him; no, no, I see you don't mind him; a little galled, but not much hurt: you may stop his mouth with a golden gag, but we'll see how he goes on."- $-\mathrm{He}$ then resumed his reading, cheering me all the way as it began to soften, till winding up in the most profest panegyric, of which he was himself the writer, I found my friend had had his joke, and I had enjoyed his praise, seasoned and set off, in his inimitable manner, which to be comprehended must have been seen.' 
But praise, even from Garrick, was not undeserved. Cumberland had not exactly waked to find himself famous, but he had won a very comfortable share of glory, and he was content. He was now known in London and Dublin as a dramatist of ability and promise. Famous men are easily persuaded that they are great. Cumberland had never felt or professed indifference to fame, and it is to be feared that he regarded it as essential rather than incidental to true greatness. Certainly no great sense of power in his heart counselled delay till he might substitute recognized genius for transient popularity. A few powerful plays he could not write. Instead he wrote many, some well, some badly. $\mathrm{He}$ sought reputation at all costs, and the years immediately following The West Indian were the golden ones. Letters written from Ireland during the summer of $177 \mathrm{I}$ reflect his satisfaction. 'It is,' he tells Garrick, 'not only individuals of the first rank in this kingdom that have caressed your undeserving friend, but the university of Dublin have, of their own mere motion and brevity, conferred upon me an honorary degree of Doctor of Civil Law, at the Public Commencement.' So many were the attentions showered upon Cumberland, that his eternal bête noir, the reviewer, held no terrors for him. 'It is well,' he confides in Garrick, 'that the snarlers at home now and then give me a snap, else I should swell like the frog in the fable, not only with Irish Hospitality, but with Irish flattery.' And he adds generously: 'I am bound to report all these flattering circumstances to you, who are the friend and father of my fame, and to whom I owe an account of everything relating to it. ${ }^{17}$

The cause of all this adulation, The West Indian, 17 Private Correspondence of David Garrick, 1.427. 
survives. The modern reader finds it an entertaining comedy, and, if interested, may discover in it a reflection of the great eighteenth century mood of sentimentalism. It tells in brisk fashion the story of Belcour, a youth all air and fire, of English parents but of tropical birth. Merchant Stockwell, apparently Belcour's guardian, but in reality his father, plans to keep the young man in ignorance of his birth that he may determine how far the irregularities of the torrid zone have affected his character. At the opening of the play Belcour is posting with characteristically hot haste from Jamaica to England, and on his arrival pursues a meteor-like career through the five acts of the play. $\mathrm{He}$ is early duped into believing that Louisa Dudley, the daughter of an English officer, may become his mistress. A closely linked episode is Charlotte Rusport's love affair with Charles Dudley, the brother of Louisa. Out of benevolence and love for the diffident Charles, Charlotte tries to restore the fortunes of old Captain Dudley. A casket of Miss Rusport's jewels, consigned to Stockwell as security in this transaction, is returned by the merchant through Belcour. This 'fallible, but not incorrigible hero,' gives them to the Fulmers, to speed his wooing of Louisa. 'If,' he cries out, 'I had the throne of Delhi, I should give it to her. ${ }^{18}$ Belcour's ardent campaign against Louisa is at length checked by the angry Charles, and the pair cross swords. They are separated by Major O'Flaherty, the admirer of Lady Rusport and the staunch upholder of sentimental virtue. Thus the Belcour episode pivots the plot. The dénouement is brought about in the capricious manner of sentimental comedy. Belcour repents of his licentious wooing, and is at once 18 The West Indian, 3.2. 
forgiven by the Dudleys; his 'libertine addresses' are dismissed with a slight reproof; and he becomes Louisa's 'reformed' and 'rational admirer.' The West Indian thus proves himself 'no unprincipled, no hardened libertine,' but one whose 'love for Louisa and for virtue is the same.' He is rewarded by the knowledge that Stockwell is his father. By the sudden appearance of a new will the fortune of Lady Rusport, who has long persecuted her niece, is transferred to Charles, thus rendering the young officer free to wed Charlotte.

Such was the plot which so delighted the age,-a plot which The Monthly Review for February, I 77 I, declared to be 'complicated without complexity,' and which two other magazines for January of the same year characterized as filled with a 'benevolence breathing ... frequently through . . . a variety of incidents.' 'This plot is,' said The Whitehall Evening Post of February 9, I771, 'a good representation of life.'

In The West Indian, perhaps, was a realization of that curious ideal of sentimental comedy well phrased in The Lady's Magazine for January,-'comedy in which elegance of language, and propriety of character are happily united with sentiment, humour, and theatrical business.' Because it happily combines these qualities a critic declares that The West Indian 'may be considered as one of the best that the present times have produced,' and The Lady's Magazine prophesies that it 'will, in all probability, continue a favourite entertainment, as long as taste and genius are encouraged in these kingdoms.' A letter to The Whitehall Evening Post of February 9, signed 'Veritas Theatrica,' declares the writer's joy at this rebirth of true comedy: 'My breast, Mr. Painter,'. he says in sentimental vein, 'is not superior to terror,- 


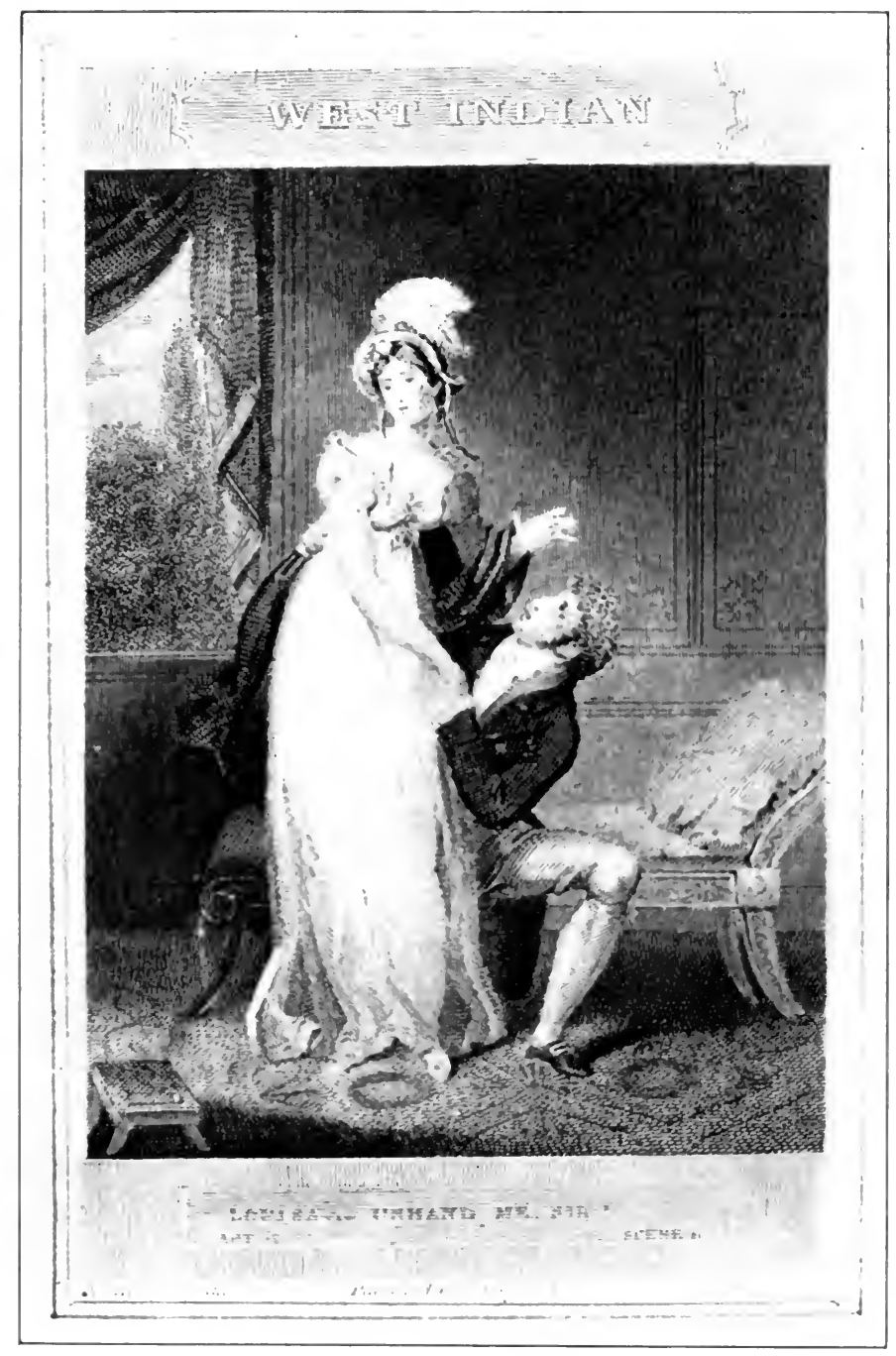



my heart is, I hope, open to sensibility,-my eye no stranger to compassion, - but at a comedy I expect and love to laugh; and I took up the pen to make my acknowledgments to an author who has gratified his inclination,-who has introduced laughter without dismissing sentiment,-and who has showed morality and mirth to be far from incompatible!' ${ }^{19}$

The West Indian soon became a stock play, and its continued popularity is made certain from an account in The London Chronicle of October 6, I 785 , of a performance 'by command of their majesties, who attended the representation, accompanied by the Princesses Royal.' 'The presence of Royalty,' says this journal, 'was not the only attraction; as the peculiar favourite of Thalia [Miss Farren] was announced to make her first appearance this season in the part of Charlotte Rusport: the house was of course filled in a very short time after the doors were opened, and numbers were obliged to return home much disappointed for want of room.'

Such comments prove clearly wherein lay the strength of the characters of The West Indian. Psychology or analysis of character was neither sought nor given. The success of Belcour and of the other characters of the play arose from effectiveness on the stage and from their sentimental value. For these were the days of sentimental comedy, and London audiences wept as tenderly for Hugh Kelly and Cumberland as they had before laughed lightly for Wycherley and Congreve. No plot was too inane if it had a moral tone; no dialogue too insipid if it abounded in platitudes upon virtue; and no character too unreal if he or she reformed in the last act. To these demands it may be seen that Cumberland

19 See also Scot's Magazine, February, 1771. 
was conforming-more, that he was unexcelled in the success with which he satisfied them. But it must be said that if he fulfilled the conventional requirements of sentimental drama, he also energized and invigorated the empty forms. Belcour and Major O'Flaherty are superior to the normal types of sentimental comedy character.

There were many guesses as to the origin of Major O'Flaherty, and rumour had it that he had been created upon the model of a distinguished Prussian officer. 'The character of Major O'Flaherty,' says The Gentleman's Magazine for July, I786, 'in the comedy of the West Indian, is not a fictitious one, but copied from the original in the person of Col. O'B-ne; who distinguished himself during many years service in the Austrian army, and is now retired upon a pension of about 2001 . per ann. with a brevet de colonel. The last time I saw him,' says this writer, 'was at the court of Bruxelles in the year 1774, where he then resided, and was much respected both by the noblesse and the military, who paid him all the honours due to so brave and honest a veteran. . .' The sketch grows like Major O'Flaherty: 'Disdaining every symptom of duplicity, he was often too open and sincere. These qualities, joined to his gallant bravery, were always ready to vindicate any affront offered to himself or to his friends. . . . He stood forward the arbiter of disputes, the mediator in quarrels . . he immediately espoused the cause of the injured or insulted, and made himself a second where he could not be admitted as principal. . . . He was a chearful companion, a solid friend, and of a generous spirit; but an implacable enemy to every species of meanness. . . .'

King O'Burne, as he was called, and Major O'Flaherty are very much alike, but, if Cumberland had the Prus- 
sian in mind, he said nothing of it in the Memoirs. 'For my Irishman,' he writes, 'I had a scheme. . . . I put him into the Austrian service, and exhibited him in the livery of a foreign master. . . . I gave him courage, for it belongs to his nation; I endowed him with honour, for it belongs to his profession, and I made him proud, jealous, susceptible. . . .'20 O'Flaherty is a figure stuffed with many kinds of straw. A quarrel with a proud Irishman 'helped me,' says Cumberland, 'to another feature in my sketch of Major O'Flaherty,' and at another time he wrote Garrick: 'Perhaps I shall be able to recruit the character of O'Flaherty with some natural touches from the county of Galway. ${ }^{21}$ For his phraseology,' Cumberland adds, 'I had the glossary ready at my hand; for his mistakes and trips, vulgarly called bulls, I did not know the Irishman of the stage then existing, whom I would wish to make my model; their gross absurdities, and unnatural contrarieties have not a shade of character in them. When his imagination is warmed, and his ideas rush upon him in a cluster, 'tis then the Irishman will sometimes blunder; his fancy having supplied more words than his tongue can well dispose of, it will occasionally trip.

The Major suffered severely on the score of morality: 'The Irishman can do no mischief,' says The Gentleman's Magazine for February, 'for the absurdity of supposing a man to be other than a scoundrel, who practices the

20 The August issue of The Gentleman's Magazine has additional comment upon Colonel O'Burne: '. . . I am personally acquainted with Colonel O'Burne,' says the writer, 'and have had frequent conversations with him relative to his long life and gallant actions in the service of the Empress Queen. . . . The Colonel is still at Brussels, where he is so much caressed that it was but seldom I could prevail upon him to eat his soup with me. He is called King O'Burne.'

21 Private Correspondence of David Garrick, 1.387. 
basest and the most cruel of all frauds, by which youth and innocence are robbed of peace and fortune, is too gross to be adopted by the weakest or most profligate wretch upon earth.' The Town and Country Magazine for January was shocked at the Major's coarse 'bulls'; The Lady's Magazine for the same month denounced him as 'low, trivial, and vulgar'; and he was generally written down as a violator of all sentimental propriety. To The London Magazine for January, I77 I, he was 'the Irish officer in Love A-la-mode, ${ }^{22}$ only without a fortune.' Davies likewise attacks O'Flaherty as being without originality or morality. 'O Flarty,' says he, '. . . is no invention of the author; Sir Callochan Obrallachan is the model from which he took the Irish Major; nor would Mr. Macklin have made his honest Hibernian act so absurdly and dishonourably as O Flarty, who insists upon Dudley's complying with the contents of a letter at the hazard of both their lives, though he does not know a syllable contained in that letter. The avowing his marrying five wives, whom he believes all to be alive and merry, is a shocking derogation from O Flarty's character of a man of worth: the words a la militaire were substituted by the actor, who thought, very judiciously, that the avowal of bigamy was too gross without a salvo.' ${ }^{23}$

22 Love à la Mode, a farce by Charles Macklin, was brought out at Drury Lane Theatre in 1759.

${ }^{23}$ Memoirs of the Life of David Garrick, 2.267-8. Major O'Flaherty's error referred to in Davies's last sentence was censured by Nugent Lord Clare [Memoirs, 1.306]: 'His lordship was contented with the play in general, but he could not relish the five wives of O'Flaherty: they were four too many for an honest man, and the over-abundance of them hurt his lordship's feelings; I thought I could not have a better criterion for the feelings of other people, and desired Moody to manage the matter as well as he could.' 
Perhaps the most hypercritical judgment of Major O'Flaherty was given one evening at Mrs. Montagu's by Lord Lyttleton. This gentleman objected to the the Major's hiding for the purpose of overhearing Varland's soliloquy. 'I consider listening,' said the peer, 'as a resource never to be allowed in any pure drama, or ought any good author to make use of it.' Cumberland longed to reply, but he lacked courage, and Lord Lyttleton was answered only in the Memoirs.

All this is taking the Major too seriously, and large audiences, troubled little about his dramatic or moral faults, came to see 'Dennis O'Flaherty who for this month has filled the theatre with repeated convulsions of laughter !'2t

To see clearly in the mind's eye an acting performance of The West Indian is to know much of Cumberland, and of his time. No effort, no thought, had been spared by Garrick and the dramatist to make the play act. For the part of Belcour had been selected Thomas King, actor and dramatist. The career of King, an idol of the people, had been striking. Engaged by Garrick for Drury Lane in $\mathrm{I} 748$, his first role had been the Herald in King Lear. During the half century in which he acted he played no less than one hundred and fifty characters, including all important comedy parts. Most of all he was famed as Sir Peter Teazle in The School for Scandal. Yet, from all evidence, the rolle of Belcour was the least fortunate on the opening night. King was not altogether successful in the rôle of the young freelance. Mrs. Inchbald says: 'King was the original Belcour; and, strange to say, that although the play had brilliant success, the hero was not properly represented.

${ }^{24}$ The Critical Review, February, 1771. 
King was, at that time, about fifty years of age, and looked to be so-he had other impediments to prevent his exactly personating the young, high-spirited, openhearted, inconsiderate West Indian.' ${ }^{25 .}$

Since the character of Major O'Flaherty was largely dependant upon good acting, the impersonator of the rôle was selected with care. The two actors considered were Spranger Barry and John Moody. It was a diffcult choice. Barry's greatness was unquestioned in all but heroic parts, and he was thought by many to be the peer of Garrick. 'Garrick,' says Francis Gentleman, author of The Dramatic Censor, 'commanded most applause, Barry most tears.' According to another writer Barry was possessed of a figure which one could not conceive 'more perfect,' and a voice 'the harmony and melody of whose silver tones were resistless.' On the other hand, Moody by his native comic genius seemed created for the part. Cumberland himself preferred Barry, though he did not think fit to urge his plea strongly. Proof of his inclination towards Barry may be had in a letter to Garrick. Writing him from Kildare Street on July 4, I 77I, he says: 'I am wishing that Barry could get up the part of O'Flaherty, and she [Mrs. Barry] that of Miss Rusport, and though I shall not signify my wish to them after what has passed from $\mathrm{Mr}$. Barry on the same subject ... yet I am privately told they will privately get it up ... They are very angry with Moody . . . and indeed, between us, he committed some wanton follies under the name of O'Flaherty. ${ }^{28}$ Cumberland describes Garrick's perplexity, and final decision for Moody: 'Barry was extremely anxious to play the

25 The British Theatre, 18, 'Prefatory Remarks to "The West Indian.", ${ }^{26}$ Private Correspondence of David Garrick, 1.426. 


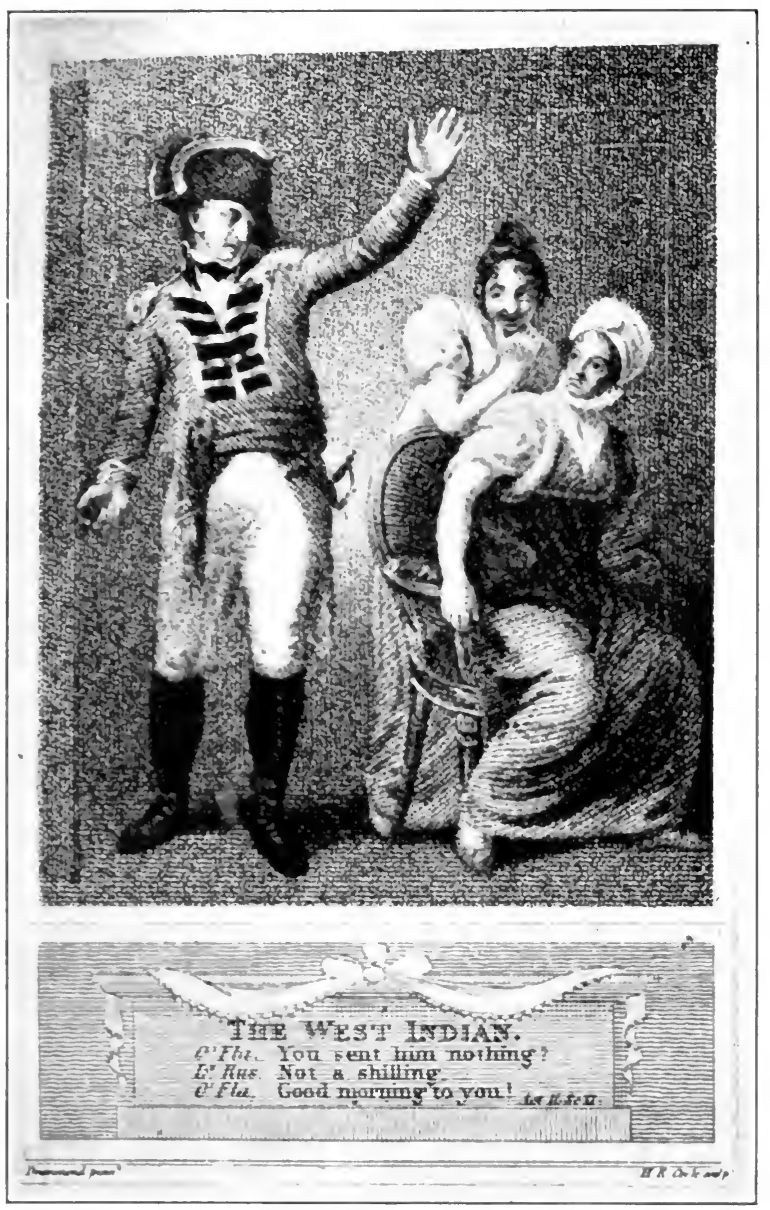



part of the Irish Major, and Garrick was very doubtful how to decide, for Moody was then an actor little known and at a low salary. . . . I remember Garrick after long deliberation gave his decree for Moody with considerable repugnance; qualifying his preference of the latter with reasons, that in no respect reflected on the merits of $\mathrm{Mr}$. Barry-but he did not quite see him in the whole part of O'Flaherty; there were certain points of humour, where he thought it likely he might fail, and in that case his failure, like his name, would be more conspicuous than Moody's.'

Moody made a success of the part. "To crown the hopes of nis rising reputation,' says an old book of dramatic annals, The Thespian Dictionary, 'he was reserved for Major O'Flaherty in the last new comedy of The West Indian; a character he has supported with such judgment, and masterly execution, as to divide applause with the author by making a subordinate character (though not the hero of the fable) the hero of the audience., ${ }^{27}$

Insipid has been applied to the drama of the eighteenth century as often as artificial to the whole literature of the period. But imagine a performance of The West Indian quickened by the genius of King and Barry. In commenting upon the brilliance of sentimental comedy on the stage, and upon the success of Mr. Douglass's American company in these plays, Seilhamer makes a strong appeal for the old drama: 'This list of productions new and old, must be acknowledged as extraordinary. It included the best of the English dramatists from Shakes-

27 The Thespian Dictionary, or Dramatic Biography of the Eighteenth Century. See also Memoirs of Tate Wilkinson, 2.97: 'Mr. Moody's O'Flaherty, and many principal comic characters have been, and are still, felt and remembered. . . .' 
peare to Kelly and Cumberland. With the single exception of Shakespeare the works of all these playwrights have been banished from the stage. . . . Neither Cibber nor Farquhar, nor Rowe, Lee nor Whitehead, Steele nor Macklin, Foote nor Garrick, Murphy nor Colman, Bickerstaff nor O'Hara, Kelly nor Cumberland has heen accorded a revival since early in the century. . . . There is no actress on the English speaking stage capable of playing these high comedy roles. No living manager, except Augustin Daly has sufficient knowledge of stagebusiness to produce one of these masterpieces of the last century. If "A Word to the Wise" or the "Fashionable Lover" was to be played by any company except his, it would be so utterly lacking in the flavour of the old school that we should think our grandfathers were satisfied with very insipid stuff. And yet were it possible to realize, even in imagination, the performances of $\mathrm{Mr}$. Douglass' company for a season, we should learn how completely the Nineteenth century has failed to realize the dramatic promise of the Eighteenth. ${ }^{28}$

Of Mrs. Abington's ${ }^{29}$ performance of the heroine many records have come down to us. The enormous success of this actress in Dublin had induced Garrick to again bring her to London, and for a number of years she had pleased the town as Beatrice, Lady Townley, Lady Betty Modish, and Millamant. She was still to Walpole 'the very person,' and to Garrick 'the worst of bad women.' Mrs. Abington's acceptance of the rôle of Charlotte Rusport was thought a condescension, since she 'would not allow it to be anything but a sketch,' but

28 Seilhamer, History of the American Theatre, 1.298-9.

29 Among Cumberland's letters in the British Museum are three written [after 1781] to Mrs. [Frances] Abington upon theatrical business. 
her triumph was immediate and lasting. A letter to The Whitehall Evening Post of February 9 gives a lively description of her Charlotte Rusport. 'Mrs. Abington,' says her admirer, 'is inimitable. I have seen this lady with much pleasure in all the humorous parts of Comedy not even surpassed by $\mathrm{Clive}^{30}$ herself. I have seen her at other times representing so naturally the sprightly levity of a young lady of fashion, as to lead me almost to conceive she had spent her whole life in the politest circles. In the play before us, though the Poet has not drawn her character in the stile of the lively comic, yet she gives it such a spirit in some passages, that one would suppose she had been cast into the part of Miss Rusport merely to shew the town that her powers in comedy are unlimited. With elegance of person and deportment, livelyness of manner, and a perfect understanding of everything she undertakes, she never fails of contenting her audience, and of impressing them with the deepest sense of her extraordinary abilities.' The success of the piece, and Mrs. Abington's fame as Charlotte Rusport were strongly augmented by her rendering of the epilogue, a clever bit of whimsicality from Garrick's pen. 'The Prologue and Epilogue, which are excellently adapted to the Play,' says The British Chronicle of January 30, 'were spoken by Mr. Reddish and Mrs. Abington, whose comic powers were finely displayed in the latter, by the recital of the Young Miss's Catechism, in which the manners of a Woman of Fashion in Queen Elizabeth's age, are humourously compared with those of our modern fine ladies.'

${ }^{30}$ The famous Kitty Clive was engaged at Drury Lane Theatre about 1728 by Colley Cibber. Her comic genius won her instant success. She enjoyed the friendship of Garrick and Walpole. 
The comparison of the unlucky subjects of Queen Elizabeth with those of George the Third ran in part:

Don't snarl and sigh for good Queen Bess's days;

For all you look so sour and bend the brow,

You all rejoice with me you're living now.

No play of Cumberland's and few of the age furnished rôles for so many distinguished actors and actresses as The West Indian. The second player of Belcour was William Thomas Lewis, famed as actor and manager and universally known as 'Gentleman Lewis.' $\mathrm{He}$ is described by Cooke, the actor, as 'the unrivalled favourite of the comic muse in all that was frolic, gay, humourous, whimsical, and at the same time elegant'; Hazlitt writes of 'gay, fluttering, hare-brained Lewis, . . . all life and fashion and volubility and whim, the greatest comic mannerist perhaps that ever lived.' As Belcour Lewis was very successful, and undoubtedly pleased Cumberland better than King. 'I am firmly of the opinion,' he wrote to Garrick in $\mathrm{I} 77 \mathrm{I}$, 'the lad has faculties to make a figure in comedy, ${ }^{31}$ a prediction verified, for the dramatic reviewer of The London Chronicle wrote a dozen years later: 'Lewis's Belcour has long been admired, but never more deservedly than last night. ${ }^{{ }^{32}}$ Major O'Flaherty was later played by 'Irish' Johnstone, renowned as Sir Lucius O'Trigger, and as Brulgruddery in The Committee, and by Edward Shuter, the stock actor for such characters as Scrub, Master Stephen, and Launcelot. Charlotte Rusport was rendered occasionally by 'the lovely and accomplished Farren,' an actress revered by Cumberland. 'Miss Farren,' says Mrs. Crouch in her Mem-

31 Private Correspondence of David Garrick, 1.43.

32 The London Chronicle, October 6, 1785. 
oirs, 'looked charmingly in the lively and elegant Charlotte Rusport.' ${ }^{33}$

The West Indian was acted throughout Europe and in America. It was translated into many languages, including the Bohemian. The play's popularity persisted during the rest of the eighteenth century, and it was frequently revived in the nineteenth. No historian of the British theatre may ignore The West Indian. In this play Cumberland achieved dramatic effects which he never afterwards equalled, and by it he gained a secure if not an eminent place in British drama.

${ }^{33}$ Memoirs of Mrs. Crouch, 1.166. 


\section{CHAPTER VI}

\section{THE FASHIONABLE LOVER}

THE unceasing popularity of The West Indian might 1 well have maintained Cumberland's reputation for a season, for his position as a successful dramatist was now unquestioned. But his ambitions were still unsatisfied. The theatrical battle was unending; Cumberland's victories, if decisive, had not been many, and there were mighty rivals in the field. It may even be believed that in these days of hope he had dreams of a time when he should brook no dramatic rival. Moreover, from his youth Cumberland had never been long idle. Even when engaged upon The West Indian he was working over other plays. Early in July, I77 I, he writes Garrick that a 'growing comedy,' The Fashionable Lover, is under way. This, he declares to his friend, 'comes out purified by your fiery trial, and less drossy than it would otherwise have been. . . This will be ready in time if it pleases God I have my health.' ${ }^{1}$

In addition, the manuscript of Timon of Athens had been retouched, and Cumberland now hoped that Garrick would accept it. 'I am looking homewards,' he writes to his manager from Clonfert, 'but if accident or illness either to self, family or friends, clogs my chariotwheels in my return to you, father, I beseech you, favour my half-begotten brat, called "Timon"; give him a good

1 Private Correspondence of David Garrick, 1.427. 
coat on his back, and send him into the world like a gentleman's son.' ${ }^{2}$ There is no reason to think that Garrick thought more highly of this adaptation than when he had rejected it three years before, but the author of The West Indian was not as easily refused as a dramatist unknown to fame. The actor must have weakened, or have made one of his efficient condensations, for three weeks later Cumberland writes to thank him for his 'approbation.' 'I flatter myself,' he says, 'Timon will open the season successfully and brilliantly.'

Timon of Athens was acted at Drury Lane Theatre on December 4, I77I. The hopes of Cumberland, and of Garrick, if he shared them, were not realized, and Doctor Hoadley was forced to comfort Garrick with his opinion that Lucius, the miserly senator in the play, was 'truly Shakespearian." Walpole saw the piece, and has a characteristic comment: "There is a new Timon of Athens, altered from Shakspeare by $\mathrm{Mr}$. Cumberland, and marvellously well done, for he has caught the manners and diction of the original so exactly, that I think it is full as bad a play as it was before he corrected it.' The remark of Doran, the dramatic historian, that in the play were 'more of Cumberland and less of Shakespeare than the public could welcome, ${ }^{16}$ has less wit but more truth. Cumberland was doubtless hindered by being forced to compete with another adaptation of the play. Thomas Shadwell's version of Timon of Athens had been acted in 1678 , and had achieved some success.

\footnotetext{
2 Private Correspondence of David Garrick, 1.434.

3 Ibid., 1.427.

4 Ibid., 1.448.

${ }^{5}$ Letters of Horace Walpole, Toynbee ed., 8.117.

${ }^{6}$ History of the Stage, 2.68.
} 
Of his drama the author is reported to have said, after a respectful tribute to Shakespeare: 'I can truly say that I have made it into a play.'

Cumberland's alterations, briefly stated, consisted in the omission of original scenes, the deletion of particular passages, and the substitution of new for old characters. The fifth act is Cumberland's. Phyrnia and Timandra do not appear in the play, and Timon is given a daughter, Evanthe, beloved by Alcibiades. Cumberland asserts that 'the entire part of Evanthe, and, with very few exceptions, the whole of Alcibiades are new.'

A 'lame and wretched alteration," says Arthur Murphy, and Davies in a long critique declares it 'a miserable alteration of one of Shakespeare's noblest productions.' 'It is almost impossible,' says this enemy of Cumberland's, 'to graft large branches upon the old stock of Shakespeare; none have succeeded in their alterations of that poet, but such as have confined themselves to the lopping off a few superfluous boughs, and adding, where necessary, some small slips of their own, and that too

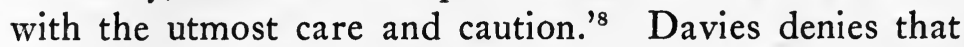
the play is equal to Shadwell's Timon of Athens. 'Mr. Cumberland has, by his management, utterly destroyed all pity for the principal character of the play. Shadwell gave Timon a mistress, who never forsook him in his distress; but Mr. Cumberland has raised him up a daughter, whose fortune the father profusely spends on flatterers and sycophants: this destroys all probability, as well as extinguishes commiseration. What generous and noble minded man, as Shakespeare has drawn his Timon, would be guilty of such baseness, as to wrong his child,

${ }^{7}$ Life of David Garrick, 2.89.

8 Memoirs of the Life of David Garrick, 2.268-70. 
by treating his visitors with the wealth that should be reserved for her portion?'9

The summer preceding the acting of Timon of Athens had also seen the completion of The Fashionable Lover. Garrick's faith in Cumberland was strong, and he hoped that The Fashionable Lover might outdo The West Indian. On May 9, I77I, he wrote Doctor Hoadley: 'There is great Merit, \& for ye faults, he shall mend 'Em in his next play, which he certainly will do, if he goes on improving as he did from ye Brothers (his first play) to his last, the West Indian.'10

In composing The West Indian Cumberland worked intensely, yet distrustfully, for his powers were untried, and Garrick's hand was everywhere upon the play. But his next play, The Fashionable Lover, written near the apex of his fame, aimed not to attain success, but to perpetuate it, and Cumberland composed with the consciousness of past achievement. 'I was aware,' he says, 'I had some little fame at stake, and bestowed my utmost care and attention upon the writing of this comedy.' In August, I77I, Cumberland had gone to Clonfert 'to catch a glimpse of unsophisticated Nature.' 'I would,' he declares to Garrick, 'fain do something for you that should live: I write with double zeal, because I think I am in some degree serving your fame as well as my own; and I proceed with confidence, because I know my production, if it can pass your scrutiny, must make its way with the public.'11

Cumberland's excessive sensibility is apparent in the

${ }^{9}$ Memoirs of the Life of David Garrick, 2.268-70.

10 Some Unpublished Correspondence of David Garrick, 45.

11 Private Correspondence of David Garrick, 1.430. 
letters to Garrick at this period. The last letter quoted has a warmly tinted signature, and in the letter of August 5 the author speaks from a rather shallow rill of emotion. He praises the time when "The West Indian" gave me your regard, and bestowed all mine upon you,' and adds with some hyperbole that 'it did more for me than the best production ever did for its author before. ${ }^{12}$

In a letter to Garrick, written on September 8, he announces the completion of The Fashionable Lover. With his usual adulation of his patron he says: 'I have looked for you amongst our bogs, and sometimes in a brighter moment I have seen you. It is then I have pleased myself; it is then my Muse has been my favourite; and at length I have completed my work. You ask, does it please me? I tell you, with sincerity that does not fear the imputation of vanity, that it does please me, and very highly. I have an internal plaudit that sanctifies my effort, and I am satisfied I shall put into your hands a work more worthy your protection than any I have yet committed to the public.' ${ }^{\text {'13 }}$

Cumberland boasts that he was famous after the production of The West Indian, and in December, I77I, a confused rumour was abroad that the dramatist was preparing a new play. 'A New Comedy,' says Lloyd's Evening Post of December 7, 'written by Mr. Cumberland, called the East Indian, the hero of which is a Scotchman, and is to be performed by Mr. Moody, is in rehearsal at Drury Lane Theatre.' Likewise, The Whitehall Evening Post of January 14 says: 'It has been given out to the Public, that the hero of the Fashionable

12 Private Correspondence of David Garrick, 1.430.

13 Ibid., 1.434. At Garrick's advice Cumberland excluded two characters from the play. 
Lover . . . was an East Indian, a surmise which probably took rise from its being the production of the same hand which wrote the West Indian; but it does appear upon rehearsal, that the fable is entirely domestic, without any allusion whatever to the East Indies throughout the piece.'

The basic idea of The Fashionable Lover had been suggested to Cumberland one evening at the British Coffee-House in a gathering of friends. At one of the meetings of this circle, perhaps in the presence of Foote, Garrick, and Goldsmith, someone declared that the success of the West Indian and the Irishman should be continued in the rôle of a 'North-Briton.' ${ }^{1 *}$ Cumberland's objection had been that opportunities such as made O'Flaherty possible were lacking. But the idea took root, and soon 'I began,' he says, 'to frame the character of Colin Macleod upon the model of a Highland servant, who with scrupulous integrity, and a great deal of nationality about him, managed all the domestic affairs of Sir Thomas Mills's ${ }^{15}$ household. . . . With no other guide for the dialect of my Macleod than what the Scotch char-

14 Cumberland records a conversation which reflects the spirit of the meetings at the British Coffee-House. In reply to Cumberland's objection to drawing a Scotch character, 'Fitzherbert observed: "How could that be, when I [Cumberland] was in the very place to find it" (alluding to the British Coffee-House and the company we were in), "however," he added, "give your Scotchman character, and take your chance for dialect. If you bring a Roman on the stage, you don't make him speak Latin —-" "No, no," cried Foote, "and if you don't make him wear breeches Garrick will be much obliged to you. When I was at Stranraer I went to the Kirk, where the Miss-John was declaiming most furiously against luxury, and, as heaven shall judge me, there was not a pair of shoes in the whole congregation."'

${ }^{15}$ Sir Thomas Mills introduced Cumberland to the circle at the British Coffee-House. 
acters of the stage supplied me with, I endowed him with a good heart, and sent him to seek his fortune.'

On January 20, I 772, it was made clear at Drury Lane Theatre that The Fashionable Lover had no connection with The West Indian. Here the audience heard Lord Abberville, 'man of the first fashion,' reveal to Doctor Druid his plan for the seduction of Augusta Aubrey. Augusta is the ward of Bridgemore, with whom she lives, together with his wife, and his daughter, Lucinda. Having forced an entrance to Miss Aubrey's room, Abberville is discovered by Lucinda in the very act of paying his unwelcome attentions to the lady. Lucinda, who is partial to Abberville, upbraids Miss Aubrey, and the latter, deeply distressed, leaves the family. While Tyrrel, Miss Aubrey's lover, searches for her, she is found by the kindly Colin Macleod, and put into the care of, as Colin supposes, a friendly Scotchwoman. This lady, however, proves to be Lord Abberville's procuress, and Miss Aubrey is again confronted by her gallant. She is opportunely rescued by Mortimer, a benevolent uncle of Tyrrel's, by Tyrrel himself, and by the ubiquitous Colin. The rest of the play deals with the exposure of Bridgemore's wrongs to Miss Aubrey, the sudden return of her father, and the repentance of Lord Abberville. 'Yours,' says he to Tyrrel, 'is the road to happiness; I have been lost in error, but I shall trace your steps and overtake you.' ${ }^{16}$

This story pleased all true lovers of sentimental comedy, and Mrs. Delany at once wrote Mr. Post that 'the play was very sentimental and pretty. ${ }^{17}$ At first blush The Fashionable Lover seemed destined to replace ${ }^{16}$ The Fashionable Lover, 5.1.

17 Autobiography, and Correspondence of Mary Granville, Mrs. Delany, 4.409. 


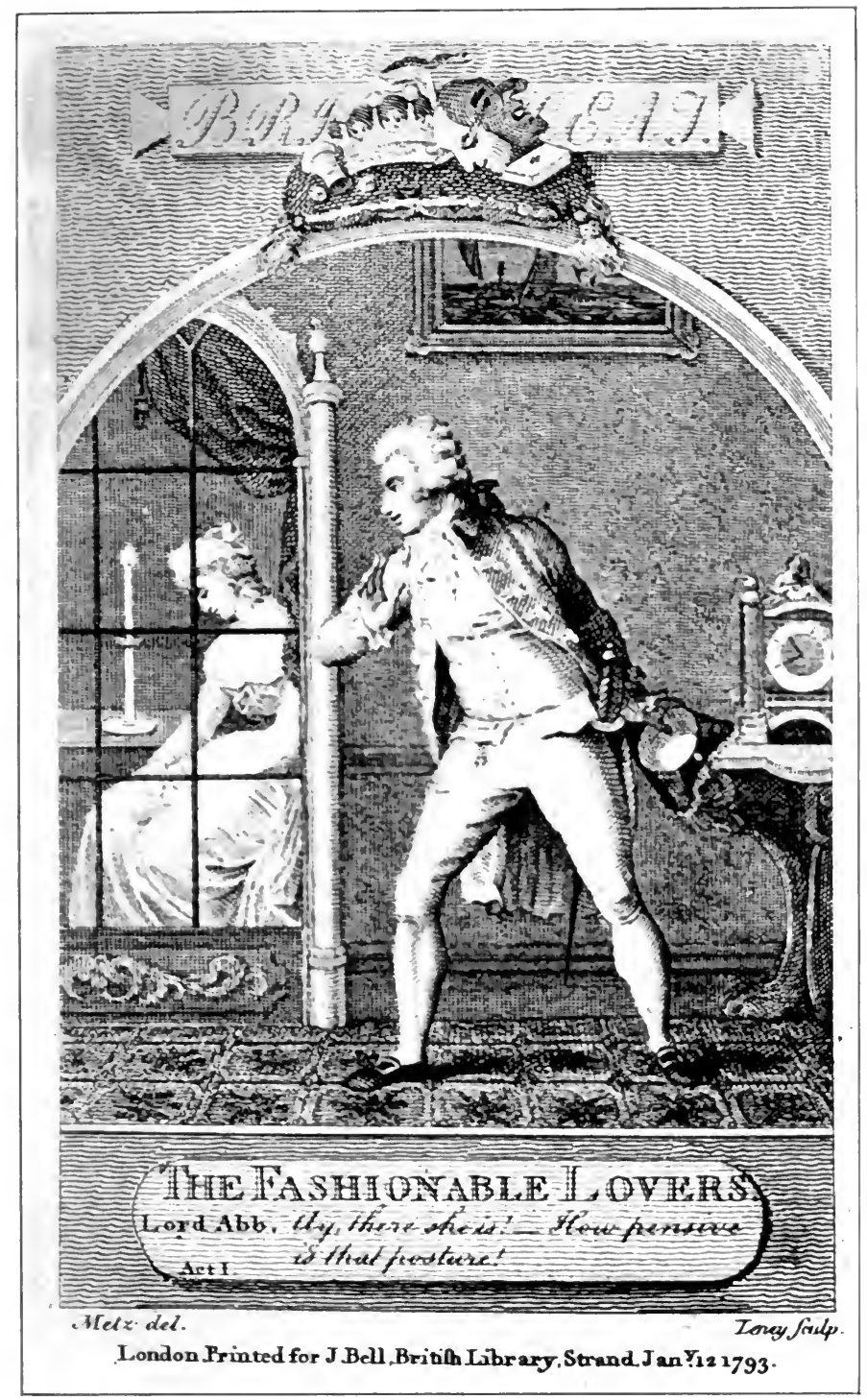



The West Indian in the popular esteem. 'On this occasion,' says The London Review for February, 'Cumberland has not fallen short of his former essays. Upon the whole, we think The Fashionable Lover no despicable effort of genius.' Similarly The St. James Chronicle of January 2 I says that The Fashionable Lover 'seems by no means likely to yield to the piece above mentioned in Merit or Success. . . .'

Other accounts, however, deny the success of the first night's performance, and attribute the final popularity of the play to shrewd changes made in the plot: 'This piece,' says Biographia Dramatica, 'followed The West Indian too soon to increase the reputation of its author. It was coldly received the first night; but undergoing some judicious alterations, improved in the public favour.' ${ }^{18}$ The Town and Country Magazine for January testifies that The Fashionable Lover failed to attain the unqualified success of The West Indian. 'Many of the critics,' the reviewer says, 'were very severe upon this piece on the first night's representation. Some were of opinion that it was destitute of the rules of comedy, and that it should with more propriety be called a dramatic tale. . . . That there was some foundation for these criticisms, we acknowledge, though they were much exaggerated by Mr. Cumberland's enemies; but by the judicious alterations made at the representations of his friends, on the second night, particularly with regard to its unpopular passages, which were entirely omitted, it is now not only a very unexceptionable piece, but there is reason to think its merit must secure it the approbation of the town, and a long run, as it contains many striking beauties.'

${ }^{18}$ Biographia Dramatica, 3.223 . 
The Whitehall Evening Post of January 22 stated that 'the unpopular passages' were political ones, and that the play met with definite opposition on the first night: 'This Piece,' the critique runs, 'some thought to have been written from some political view, as the Scotch are, in a manner, deified at the expence of the English, and several indecent reflections were occasionally thrown out against the Citizens of London, one of which, in the first Act, concerning the dignity of Tradesmen . . . created an almost general hiss, and had well nigh stopped the procedure of the Performance. The author profited from the hints next night, by judiciously pruning, or taking away, every thing that seemed to indicate a political intention, by which the piece is rendered more general, and consequently more entertaining.'

The Fashionable Lover, too, contained stolen material. Dibdin declares that the play was culled from no less than three other comedies, and a novel. It 'was,' he said, 'a most injudicious play and contained such a mixture of the "Conscious Lovers,"19 "False Delicacy," ${ }^{20}$ "Taste," and "Clarissa Harlow," that it was impossible for anything to be more heterogeneous. . . .' ${ }^{22}$ Charges of plagiarism have, however, little force when applied to The Fashionable Lover. The play belongs to the family of sentimental comedy, and a reader may, without diffculty, discover elsewhere incidents and characters similar to those of The Fashionable Lover, but Cumberland's own words, prefixed to the play, exonerate him: 'I have

10 Richard Steele's Conscious Lovers was acted at Drury Lane Theatre in 1721 .

${ }^{20}$ False Delicacy by Hugh Kelly was first performed at Drury Lane Theatre in 1768.

21 Taste by Samuel Foote was acted at Drury Lane Theatre in 1752.

22 A Complete History of the Stage, 5.287. 
on this occasion (as on the two preceding ones), wholly rested my performance upon such poor abilities, as I am master of; I am not conscious of having drawn any particular assistance, either in respect of character or design, from the productions of others; altho' I am far from presuming to say or think, that I have ever exhibited any character purely original. ${ }^{, 23}$

Whether or not the new play was realism, as the critics wished to have it, whether or not it was a huge larceny, as Dibdin maintained, was of little consequence, for its success as a stage production could not be questioned. 'The situations are well chosen,' is the comment of The Town and Country Magazine for January, 'and the attention is kept alive by the passions throughout being very sensibly affected.' The February number of The Gentleman's Magazine remarks indirectly upon the strength of the play on the stage by admitting the futility of laying the plot before the reader. To offer the skeleton of this, without the colour supplied by the acting, would 'injure the author, by exhibiting only the bran of his performance, after having sifted away the flour.' Whether dependent upon its first form or upon 'judicious alterations,' the popularity of The Fashionable Lover was assured, for as late as the end of March The London Review said that: "the representation of the Fashionable Lover still continued to bring together crowded audiences. . . .' It was not as Cumberland thought, 'the happiest effort of his pen, ${ }^{24}$ but it was, as Genest said, 'pretty good comedy. ${ }^{25}$ The play is faulty, and lacking in originality, but the reader not devoid of imagination

23 The Fashionable Lover, London, 1772, 'Advertisement,' 6.

${ }^{24}$ Mudford, Life of Richard Cumberland, 280.

25 Genest, 5.322. 
may see it in some of its old lustre. The discovery of Lord Abberville by Lucinda, and Miss Aubrey's rescue by Mortimer and Colin,- - these were not scenes to tire when acted by the Barrys or when Dodd, ${ }^{26}$ so admired by Charles Lamb, played Abberville.

The play was popular in England, and the reception in Scotland was flattering enough to please even Cumberland. A letter from 'Candidus' shows the delight of the Caledonian audiences of I802: 'Sir,' he says, 'on Wednesday, the Comedy of The Fashionable Lover or The Faithful Highlander was brought forward for the first time this season, and attracted a genteel audience. ... Every attempt to rescue the Scottish honour . . . must be highly satisfactory to the friends of their country, who are desirous to promote cordial unanimity among the inhabitants both of England and Scotland. ${ }^{27}$

Mrs. Centlivre and Charles Macklin had preceded Cumberland in creating Scotch characters for the stage. In I7 44 Mrs. Centlivre had produced The Wonder! $A$ Woman Keeps a Secret! in which appear Colonel Briton, who passes as Scotch, and his valet, Gibbey, ${ }^{28}$ who speaks a strange jargon of the Scotch dialect. In I759 was

${ }^{26}$ James William Dodd first appeared at Drury Lane Theatre on October 3, 1765, as Faddle in Moore's play, The Foundling. He was regarded as the successor of Colley Cibber in the parts of beaux or coxcombs. 'What an Aguecheek,' says Lamb, 'the stage lost in him.'

27 Candidus, The Theatre, Letter 13. An amusing sidelight is thrown on this performance of The Fashionable Lover by an angry remonstrance from 'Candidus' against disturbers of the theatre: 'MALE AND FEMALE TATTLERS again appeared in the Boxes, and carried on their attack against the audience and actors, without the smallest opposition from either. The audience and actors in Edinburgh,' concludes the writer, 'are surely most magnanimous.'

28 Gibbey, the Scotch character in an embryonic stage. In The Wonder 
acted Macklin's Love à la Mode with Sir Archy MacSarcasm, ${ }^{29}$ and in $178 \mathrm{I}$ The Man of the World with Sir Pertinax Macsycophant. The speech of both of these characters is clearer and wittier than Gibbey's, but they and he are, all three, caricatures.

Colin Macleod is different, his one link with the earlier characters being the dialect. Since Cumberland admits having taken this from Colin's predecessors on the stage, he fairly anticipates the accusation of The Whitehall Evening Post of January 25 that 'the author has repeatedly betrayed his ignorance of the Scottish manners, languages, and customs.' What Cumberland did for the Scotchman was to make him the hero of a serious drama. The original title of the play was: The Fashionable Lover, or The Faithful Highlander. And, as the paper just quoted says, 'the Scotchman is the hero, and from him the piece was to have been called The Highlander.' Colin Macleod is not the hero of a farce, like Sir Archy or Sir Pertinax, but is the first Scotchman to be the central figure of a sentimental drama. So Colin dominates all other characters in the dramatis personae, and initiates every important movement of the plot. Without him the main incidents of Bridgemore's infidelity and Miss Aubrey's trouble fall to the ground. $\mathrm{He}$ is at once the buffoon and the mainspring of the action.

But it is the moral and sentimental character of Colin Macleod that is most striking. It is not that he brings

[3.1] he says: 'Gin I be, sir, the mon that told me leed; and gin he did, the deel be my landlord, gin I dee not lick him as long as I can haud a stick in my hond, see me noo.'

${ }^{29}$ Sir Archy's dialect is nearer Colin's [Love à la Mode, 2.2]: 'Oh, Sir, ye dinna ken the law-the law is a sort of hocus pocus science, that smiles in yer face while it picks yer pocket; and the glorious uncertainty of it is of mair use to the professors than the justice of it.' 
a new era in which the virtuous Scotch are continually exhibited; it is not, as 'Candidus' hoped, 'an attempt to rescue the Scottish honour, Scottish bravery, and Scottish generosity, from the illiberal attacks of a few proud, narrow-minded Englishmen' $;^{30}$ and it is untrue that Colin represents 'a fulsome compliment to the Scotch, at the expence of the English, ${ }^{31}$ for Cumberland cared as little for Scotland and the Scotch as an Englishman could care. The significance of Colin's moral and sentimental position in the play lies in the light he throws upon Cumberland's own moral attitude, and upon his conception of the drama as a channel for its expression. Cumberland aimed to correct an English prejudice by displaying virtue in Scotch costume. So Colin is open-hearted, frank, generous, endowed with every virtue, and, in particular, with those which were generally denied his nation. 'We cannot,' says The London Review for February, 'help expressing our admiration of the author's hardiness in making a Scotchman generous. The prejudices of the time deny them that virtue, though the Highlands be perhaps the only corner of the island, where genuine hospitality still remains.' The success of Cumberland's moral character is evident from the following critique in The St. James Chronicle of January 2 I : 'The Introduction of a Scotch Character, with his national Peculiarities, and the reconciling Light in which he was put, by the artful and judicious contrivance of the Author, is an Attempt that does Honour to his Heart and to the Stage, by restoring it to its noblest Uses.'

Colin Macleod pleased Boswell. During the trip to the Hebrides he writes in his diary: 'It was a storm of

30 'Candidus,' The Theatre, Letter 13.

31 The Town and Country Magazine, January, 1772. 
wind and rain; so we could not set out. I wrote some of this Journal, and talked awhile with Dr. Johnson in his room, and passed the day, I cannot well say how, but very pleasantly. I was here amused to find $\mathrm{Mr}$. Cumberland's comedy of the Fashionable Lover, in which he has very well drawn a Highland character, Colin M'Cleod, of the same name with the family under whose roof we now were. ${ }^{32}$

The Fashionable Lover was acted about fifteen times. Cumberland's wish that each new play should surpass the last led him into the error of believing that The Fashionable Lover was superior to The West Indian. The prologue to the play openly expresses his preference:

Two you have reared; but between you and me,

This youngest is the fav'rite of the three. ${ }^{33}$

'I confess,' the author adds in the Memoirs, 'I flattered myself that I had outgone The West Indian in point of

32 Life of Johnson, Hill ed., 5.200.

${ }^{33}$ The prologue and epilogue were very popular. 'The piece,' says The Oxford Magazine for January, 'was opened with a humourous Prologue, spoken by Mr. Weston, in the character of a Printer's Devil.' In The Recollections of the Life of John O'Keeffe [1.344-5] occurs a story of an incident connected with this prologue. The Fashionable Lover was being performed in a Dublin theatre: 'Dawson was manager, and up in one of the boxes to watch the performance: his son George, a lad of fifteen, had to speak a prologue. . . The house was crowded, the actors, manager, and audience, all in full hopes. The prompter's bell rang, when in walked George Dawson . . . his face and hands blackened, and an old newspaper twisted and pinned like a cap about his head. There he stood, silent and terrified: at last he stammered out the first line of the prologue. "I'm the Devil, so please you." Not another word could he remember, so began again, bowing, "I'm the Devil, so please you." And then again to the wonder and amusement of the audience, bowed and repeated, "I'm the Devil, so please you," and fairly ran off the stage.' 
composition. . . . I have been reading it over with attention; and so many years have passed since I wrote it, that I have very little of the feeling of the author when I speak of it. I rather think I was right in giving it the preference to the West Indian, though I am far from sure $I$ was unprejudiced in my judgment at that time. . . . I verily believe if The Fashionable Lover was not my composition, and I were called upon to give my opinion of it, . . . I should be inclined to say it was a drama of a moral, grave and tender cast. . . I could not deny it a preference to the West Indian in a moral light, and . . . I might be tempted to say that in point of diction it approached very nearly to what I conceived to be the true style of comedy.'

Superior to The West Indian, The Fashionable Lover was not, but it was, indeed, 'a drama of a moral, grave and tender cast,' and proved the nature of Cumberland's talents. Didacticism was very strong in Cumberland, and this, combined with real virtue, led him to attempt nothing less than to reform public opinion. Sentimental comedy was to be the agent of correction. As in The West Indian Cumberland had aimed to change the popular conception of the stage Irishman by exhibiting the moral O'Flaherty, he now made the hero of his play, Colin Macleod, a Scotchman who is generous, unselfish, and devoted to the cause of virtue. Cumberland's longing for fame and his belief in the mission of moral drama permeate the Memoirs, and have something of the pathos of all dead hopes. First as the leader of sentimental comedy he condemns the meretricious Restoration drama: 'Congreve, Farquhar, and some others have made vice and villany so playful and amusing, that either they could not find it in their hearts to punish 
them, or not caring how wicked they were, so long as they were witty, paid no attention to what became of them: Shadwell's comedy is little better than a brothel.' That Congreve could live, Cumberland would not believe, nor had he faith in the wit of Samuel Foote and his fellows: 'A true poet,' he says in oracular fashion, 'knows that unless he can produce works, whose fame will outlive him, he will outlive both his works and his fame; therefore every comic author who takes the mere clack of the day for his subject, and abandons all his claim upon posterity, is no true poet; if he dabbles in personalities, he does considerably worse.' The purpose of the moral dramatist is then set forth: 'When I began therefore, as at this time, to write for the stage, my ambition was to aim at writing something that might be lasting and outlive me; when temporary subjects were suggested to me I declined them: I formed to myself in idea what I conceived to be the character of a legitimate comedy, and that alone was my object, and though I did not quite aspire to attain, I was not altogether in despair of approaching it. I perceived that I had fallen upon a time, when great eccentricity of character was pretty ncarly gone by, but still I fancied there was an opening for shewing at least my good will to mankind, if I introduced the characters of persons, who had been usually exhibited on the stage, as the butts for ridicule and abuse, and endeavoured to present them in such lights, as might tend to reconcile the world to them, and them to the world. I thereupon looked into society for the purpose of discovering such as were the victims of its national, professional or religious prejudices; in short for those suffering characters, which stood in need of an advocate, and out of these I 
meditated to select and form heroes for my future dramas, of which I would study to make such favourable and reconciliatory delineations, as might incline the spectators to look upon them with pity, and receive them into their good opinion and esteem.' 


\section{CHAPTER VII}

\section{DRAMATIC ACHIEVEMENT.-GOLDSMITH}

R ICHARD CUMBERLAND, the dramatist, was R now living in Queen-Anne Street West at the corner of Wimpole Street. The pleasant Fitzherbert had a house in the same street, and Edmund Burke lived almost opposite. 'A little straw,' says Cumberland, 'will serve to light a great fire, and after the acting of the West Indian, I would say, if the comparison was not too presumptuous, I was almost the Master Betty of my time.' These were the best years of Cumberland's life. Such success as he had fate could not take from him, and one of his rewards was his wide acquaintance with the great figures of the age. During the next few years he knew well Garrick, Johnson, Goldsmith, Reynolds, Sheridan, Foote, 'Ossian' Macpherson, Doctor Beattie, and others less known to fame. But the friendships were often one-sided. His unusual personality at once attracted and repelled. Fame demands a price-the knowledge of her favourites' faults, and as Cumberland became better known, his strange twists of mind were fruitful themes for jest.

The undeniable success of The Fashionable Lover could not make Cumberland forget the attacks of the critics. He writhed unceasingly under their careless stings. 'He is,' said Garrick impatiently, 'a man without a skin!' Partly from a natural desire to justify his powers, partly from industry, he wrote play after play. 
He seemed determined to stem the increasing tide of criticism by the very number and frequency of his productions. 'Mr. Cumberland,' complained Arthur Murphy, a brother dramatist, 'was resolved not to let his muse have time to rest.' ${ }^{1}$ Cumberland was recognized as the perennial producer for Drury Lane, and writer of epilogues for all plays. 'Mr. Cumberland's "Epilogue,", says Walpole wearily, 'is a very long riddle, which I guessed from the two first lines." And in an excess of boredom he writes the Countess of Ossory: 'What should I read else? I know all that can be told me of the periods I delight in. I can scarce read Grammont and Madame de Sevigné because I know them by heart. Can I pause over American disputes which I never did nor ever shall understand? Do I care for hearing how many ways Mr. Burke can make a mosaic pavement or an inlaid cabinet? Can I be diverted by Mr. Cumberland's comedies, or Garrick's nonsensical epilogues?'3

By the summer of 1773 the resentment in Garrick aroused by Cumberland's importunities had taken a definite turn. Cumberland was just now seeking to bring out a new farce, The Note of Hand. His letter to the Drury Lane manager is exceedingly brief and formal. It runs :

Queen Ann's Street, June 27, 1773.

Mr. Cumberland presents his compliments to Mr. Garrick, will take an early opportunity of reading him the piece of two acts, agreeable to his promise, as soon as he has completed the alteration which Mr. Garrick recommended. He will transmit it from

1 Life of David Garrick, 2.109.

2 Letters of Horace Walpole, Toynbee ed., 7.338.

3 Ibid., 9.127-8. 
Ireland before the season commences, in time for any purpose Mr. Garrick may have for it, though ever so early. Mr. Cumberland leaves town in a few days. ${ }^{4}$

Garrick's note, which contains exactly ten more words than Cumberland's, and which is dated the same day, promises to read the play, but says that Mr. Garrick is 'much surprised after so long a silence to receive his note of yesterday.' The letter ends with something very like a sneer: Mr. Garrick 'little thought, after he was informed of his new scheme, that he should have been honoured again with his [Cumberland's] commands.'

What the 'new scheme' was is conjectural, but it is probable that Garrick alludes to the efforts of Cumberland and some friends to establish the actor, Henderson, ${ }^{6}$ in London, a supposition rendered likely by Cumberland's later reference to it as a plan for 'the promotion of genius.'

The dramatist's reply to the innuendo is dignified and manly, and displays a defiance that seems almost to proclaim a new Cumberland. 'I perceive,' he says, 'you write to me under resentment, and it is plain you allude to the cause, when you tell me of the new scheme I have been engaged in. Weak as the foundations are on which you build your anger, I am yet well content you should have some plea for your neglect of me; and I had rather that excuse should spring from passion (though self-interest be the root of it) than be found to proceed from lassitude in friendship, and that insen-

\footnotetext{
4 Private Correspondence of David Garrick, 1.551.

${ }^{5}$ Ibid., 1.552.

' John Henderson acted in Cumberland's Battle of Hastings, The Mysterious Husband, Don Pedro, and The Arab.

${ }^{7}$ Private Correspondence of David Garrick, 1.552.
} 
sibility of nature which is more unconquerable than aversion itself. It is true, Sir,' Cumberland continues, 'I have been engaged in an undertaking, which had for its object the promotion of genius. I have been tempted to subscribe my opinion at the instigation of friends whose judgment I hold sacred, and amongst them by some which you and I enjoy in common, who, like myself, did not apprehend you would have resented an effort, founded in public spirit, and which neither aimed nor aspired to affect a fortune and a fame, which your unequalled merits have long made secure, and promise to transmit without impeachment to posterity. ${ }^{\prime 8}$

In I 773 Henderson, whose great powers were beginning to manifest themselves, had acted before Garrick at Bath, and aroused his jealousy by a fine performance of Benedick. Garrick was secretly resolved to suppress Henderson, and Cumberland, whose part in the affair seems to have been an honourable and kindly effort to bring the actor forward, says: 'When I had seen him in different characters, and became confirmed in [my] opinion of his merit I warmly recommended him to $\mathrm{Mr}$. Garrick.' The latter apparently contracted for Henderson's engagement, but Cumberland soon saw that he was 'cool in the business.' Henderson's idea of the situation is clear in a letter to a friend: 'You are to know then that I think Mr. Garrick has acted very illiberally and ungentlemanly in my regard-I will tell you how $\mathrm{Mr}$. C—d sent to me the other morning, after my playing Benedict, to compliment and applaud me. $\mathrm{He}$ told me that he was astonished at my performance, that Mr. Garrick had prepared him for a very different opinion. - Mr. C C d then shewed me a letter from him,

8 Private Correspondence of David Garrick, 1.552. 
wherein he says, "See Henderson more than once, and give me your real opinion of him"-Mr. C_- d did so, and that opinion was the most kind and favourable that could be imagined. Yet Mr. G- took no manner of notice of it, though he constantly wrote to $\mathrm{Mr}$. C-d. . . .

Cumberland persisted in behalf of Henderson, whose gratitude was overflowing. Although Garrick was temporarily successful in checkmating his rival, making 'the transfer of his property in the theatre without the name of Henderson upon the roll of his performers,' yet Cumberland ultimately secured his appearance in a play of his own. 'Truth obliges me to say,' says the dramatist, 'that the negociation in all its parts and passages was not creditable to Mr. Garrick, and left impressions on the mind of Henderson, that time did not speedily wear out. . . . When the Haymarket house opened, Henderson came from Bath with all the powers of his genius on the alert and upon the summer stage fully justified every thing that $I$ and others had said of him. . . . A great resort of men of talents now flocked around him; the town considered him as a man injuriously rejected . . . yet when Garrick found that by lending his ear to foolish opinions, and quibbling about terms, he had missed the credit of engaging the best actor of the time, himself excepted, it is not to be wondered at if the praise, bestowed on Henderson's performances, was not the most agreeable topic, that could be chosen for his entertainment.' When Drury Lane came under the management of Sheridan, Henderson was transferred there and acted Edgar in The Battle of Hastings. Garrick's resentment did not vanish immediately. A year later he wrote

' Letters and Poems by the Late Mr. John Henderson, 145, 147. 
Colman of Cumberland: 'He has behav'd so disagreeably with me, that I must have a pluck at his feathers, whether they belong to Terence, Shadwell, or are of his own growth.'

On February 9, I774, the same year in which this correspondence took place, The Note of Hand was performed at Drury Lane Theatre. The piece was acted about thirteen times. A synopsis indicates the trivial nature of this dramatic effort. Rivers, ruined at cards by Sunderland, is saved only by the generosity of Mrs. Chevely, a widow secretly in love with him. This lady sends Rivers an extraordinary 'note of hand' promising 'to surrender on demand, the heart, hand, and fortune of Maria Chevely.' ${ }^{10}$ The note travels wide of its destination, but at last reaches Rivers, and, when he is united to Mrs. Chevely, Sunderland reveals himself as a benevolent uncle. O'Connor, MacCormuck, Sapling, Dipp, Putty, and Spavin direct an amusing underplot.

The Note of Hand was the last play of Cumberland's produced by Garrick before leaving the stage, and was written at the desire of Moody for another Irish character as successful as Major O'Flaherty. While the farce was not, as Dibdin says, 'equal to the masterpieces of Murphy or Colman, ${ }^{11}$ it was fairly successful, and the critics were friendly. The London Magazine and The Town and Country Magazine for the month of February both point out the absurdity of the plot, at the same time that they notice the humour and power of observation in the piece, while The Monthly Miscellany for March, Lloyd's Evening Post of February I I, and Scot's Magazine for February, agree in thinking it excellent satire.

10 The Note of Hand, 2.2.

11 A Complete History of the Stage, 5.287. 
How pointed was this satire may be seen in the following passage taken from The London Magazine for February: 'In the course of this farce we discover, in a variety of situations, a view of the many infamous and ridiculous practices of several of the frequenters of Newmarket races, under the honourable appelation of Black Legs, particularly the character of a gaming statesman, and three broken tradesmen, whose neglect of business, and dissipations of the town, have forced on their disgraceful mode of existence.'

'The gaming statesman,' MacCormuck, was created as a caricature of Charles Fox. Cumberland's picture of the leader of the Whig party as a dissolute politician was a dangerous pleasantry, and one which was not to go unpunished. He had aroused the anger of the Whigs, and, in particular, that of Richard Brinsley Sheridan.

When, on December 19 of the same year, Cumberland brought out The Choleric Man, he was still smarting from the onslaughts of the critics, and, stirred beyond control by a particularly venomous assault, he broke silence, and prefixed to the printed copy of the comedy a Dedication to Detraction. This piece of irritable and undignified prose could do nothing but recoil upon the writer. 'If the reader,' says Arthur Murphy, 'wishes to have a true idea of a choleric man, he will find it in the Dedication to Detraction.'12

This comedy has nothing original to commend it. 'The Choleric Man,' Andrew Nightshade, a bully who lives by the very breath of quarrel, has the pleasant peculiarity of educating his son Jack as a footman. The other son has, meanwhile, been normally reared under the guardianship of Manlove, Nightshade's brother, and the

12 Life of David Garrick, 2.109. 
adventures of the eccentric Nightshades, while visiting Manlove, form the backbone of a diverting plot. Andrew is finally frightened from a long course of churlishness by rough handling from a mob, and ends his career in mild repentance. Jack, duped by Dibble, carries on a clumsy wooing of Lucy, the maidservant, thinking her Laetitia, the mistress, and his gay vulgarity makes the sport of the play. Charles, the conventional lover, wins Laetitia.

Like Timon of Athens, The Choleric Man suffered by fairly inviting comparison with a great original and a modern adaptation. Critics instantly turned to the Adelphi of Terence, Cumberland's avowed model, and Shadwell's Squire of Alsatia, ${ }^{13}$ which the author denied having read. The Universal Magazine warns Cumberland that his 'acknowledging his acquaintance with Terence, in his Prologue, will not conceal him from a detection of other connections.' 'We fancy,' the reviewer says, 'he is more indebted to Shadwell's Squire of Alsatia than to the former though he has forgotten to make his acknowledgments to the humbler Poet of the two. ${ }^{14}$ Lloyd's Evening Post of December I 9 declares that Cumberland's inability to approach his great model is due to his 'having almost totally abandoned his original, both in respect to character, and to the Fable,' and says that, left to its own resources, 'the Author's Pegasus flagged, and never got into wind again.' The St. James Chronicle of December 22 indulges in a long comparison of Terence, Molière, Shadwell, and Cumberland in respect to their various treatments of this subject, 'The different Effects of a harsh and severe, and a mild and gentle Education.' 'While admitting that Cumberland is not at

13 The Squire of Alsatia was first acted in 1688.

14 The Universal Magazine, December, 1774. This magazine reprints several scenes from Act 1. 
his best in The Choleric Man, the writer bestows high praise upon his dialogue, when he finally says: ' $\mathrm{He}$ is often as witty as Congreve, as easy as Vanbrugh, and as satirical as Wycherley.'

Not yet reduced to the status of a mere writer of plays, Cumberland had high hopes for The Choleric Man. The play was acted thirteen times, ${ }^{15}$ but, with the death of Weston, passed into oblivion. The play has none of the vigour of the earlier comedies. Cumberland's prediction of its future is unlikely to be fulfilled: 'If ever,' he writes in the Memoirs, 'there shall be found an editor of my dramatic works as an entire collection, this comedy will stand forward as one of the most prominent among them.'

Dramatic vicissitudes were suddenly forgotten in a deep sorrow. During the winter of I774-I 775, while Cumberland was at Bath for his health, he received the sad news of the death of his father. While not yet recovered from this affliction, he learned of the fatal illness of his mother. 'Those senses so acute, and that mind so richly endowed, were in an instant taken from her.' 'Thus,' says Cumberland, 'was I bereft of father and mother without the consolation of having paid them the last mournful duties of a son. One surviving sister, the best and most benevolent of human beings, attended them in their last moments, and performed those duties, which my hard fortune would not suffer me to share.'

There were to be no more peaceful summers at Clonfert. The autumn of 1775 the dramatist passed in a tour of the lakes in Cumberland. While on this journey he wrote two odes. These deserve mention here, only

15 Genest, 5.444. It also enjoyed some popularity in America. See Seilhamer, History of the American Theatre, 1774-1792, 267. 
for the light that they throw upon the authour's character. A successful dramatist, he could not yet abandon the idea that he had poetic genius. The first poem, an Ode to the Sun, was unspeakably heavy and turgid. The second, an Ode to Doctor Robert James, excited the laughter of Horace Walpole and Hannah More. The poem was a grateful tribute to the physician for having cured Cumberland's son of a critical illness.

'Mr. Cumberland,' Walpole wrote Mason, 'has published two odes in which he has been so bountiful as to secure immortality for Gray, for Dr. James's powder, and indeed for his own odes, for Father Time would fall asleep before he could read them through.' ${ }^{16}$ Hannah More was astonished at this effort of the Muse: 'I tried in vain to prevail upon $\mathrm{Mr}$. Cambridge to read them; but we could not. He has a natural aversion to an ode, as some people have to a cat; one of them is very pretty, but another contains a literal description of administering a dose of James's powders.' ${ }^{17}$

The lines which delighted Hannah More and other readers ran:

The mother aids the draught, and as she aids it, prays.

Now in each other's eyes we stare

With looks that ask if hope be there.

Meanwhile, the magic drug, at strife

With the detected foe of life,

Runs to the heart, mounts to the brain,

And visits each corrupted vein.

Where'er it comes bids tumults cease,

And hail the messenger of Peace.

16 Letters of Horace Walpole, Toynbee ed., 9.335-6.

${ }^{17}$ Memoirs of the Life and Correspondence of Mrs. Hannah More, Roberts ed., 1.53. 
The Gentleman's Magazine for April, I776, in reviewing these poems, says: 'This publication consists of two odes, I. an irregular one the sun . . . On this ode Mr. Gray's journal is the best commentary, as it refers to all the scenes here hinted at. Some of his Pindaric fire seems also caught by our bard, tho' if we are not mistaken, both Messrs. Gray and Mason are great enemies to irregularity in odes . . . Ode II is addressed to (the late) Dr. Robert James, and is a just and elegant tribute to that "victorious sage, Great tamer of the fever's rage." ...'

The odes were published in 1776 by $\mathrm{Mr}$. Robson in New Bond Street. Walpole had been still further irritated by Cumberland's dedication of the odes to George Romney, the painter. This dedication, declares Walpole, 'hisses with the pertness of a dull man.'18 But Walpole was unjust. Cumberland and Romney were close friends, and the deep kindliness of Cumberland's nature, beneath his surface irritabilities, is nowhere better shown than in this friendship.

'When I first knew Romney,' he says, 'he was poorly lodged in Newport-Street, and painted at the small price of eight guineas for a three-quarters portrait: I sate to him, and was the first, who encouraged him to advance his terms, by paying him ten guineas for his performance.' In 1776 Cumberland dedicated his two odes to the painter, and at other times celebrated him in verse. Allan Cunningham said that the poetical commendations of Romney's friends might be called an 'elegant advertisement of his merit. ${ }^{19}$ In return for these poetic praises

18 Correspondence of Horace Walpole and William Mason, Mitford ed., 9.335-6.

19 Romney was generally spoken of as having been introduced by Cumberland. 
Cumberland doubtless received a number of portraits, of himself, and of his wife and daughters. Romney also copied a portrait of Cumberland's great-grandfather, the Bishop of Peterborough, done by Murray. ${ }^{20}$

Cumberland found Romney 'shy, private, studious and contemplative. . . . of a habit naturally hypochondriac, with aspen nerves, that every breath could ruffe.' $\mathrm{He}$ was 'so eager to begin, and so slow in finishing his portraits, that he was forever disappointed of receiving payment for them by the casualties and revolutions in the families they were designed for, so many of his sitters were killed off, so many favourite ladies were dismissed, so many fond wives divorced, before he would bestow half an hour's pains upon their petticoats, that his unsaleable stock was immense.'

Cumberland tells the story of a call upon Romney, accompanied by Garrick. 'A large family piece unluckily arrested . . . [Garrick's] attention; a gentleman in a close-buckled bob wig and a scarlet waistcoat laced with gold, with his wife and children, (some sitting, some standing) had taken possession of some yards of canvass very much, as it appeared, to their own satisfaction, for they were perfectly amused in a contented abstinence from all thought or action. Upon this unfortunate group when Garrick had fixed his lynx's eyes, he began to put himself into the attitude of the gentleman, and turning to Mr. Romney- "Upon my word, Sir," said he, "this is a very regular well-ordered family, and that is a very bright well-rubbed mahogany table, at which

${ }^{20}$ Chamberlain, George Romney, 83. Romney painted at least three portraits of Cumberland. The best painting of Cumberland hangs in The National Portrait Galley, in London. Another picture of Cumberland by Romney was included in the first edition of the Memoirs. 


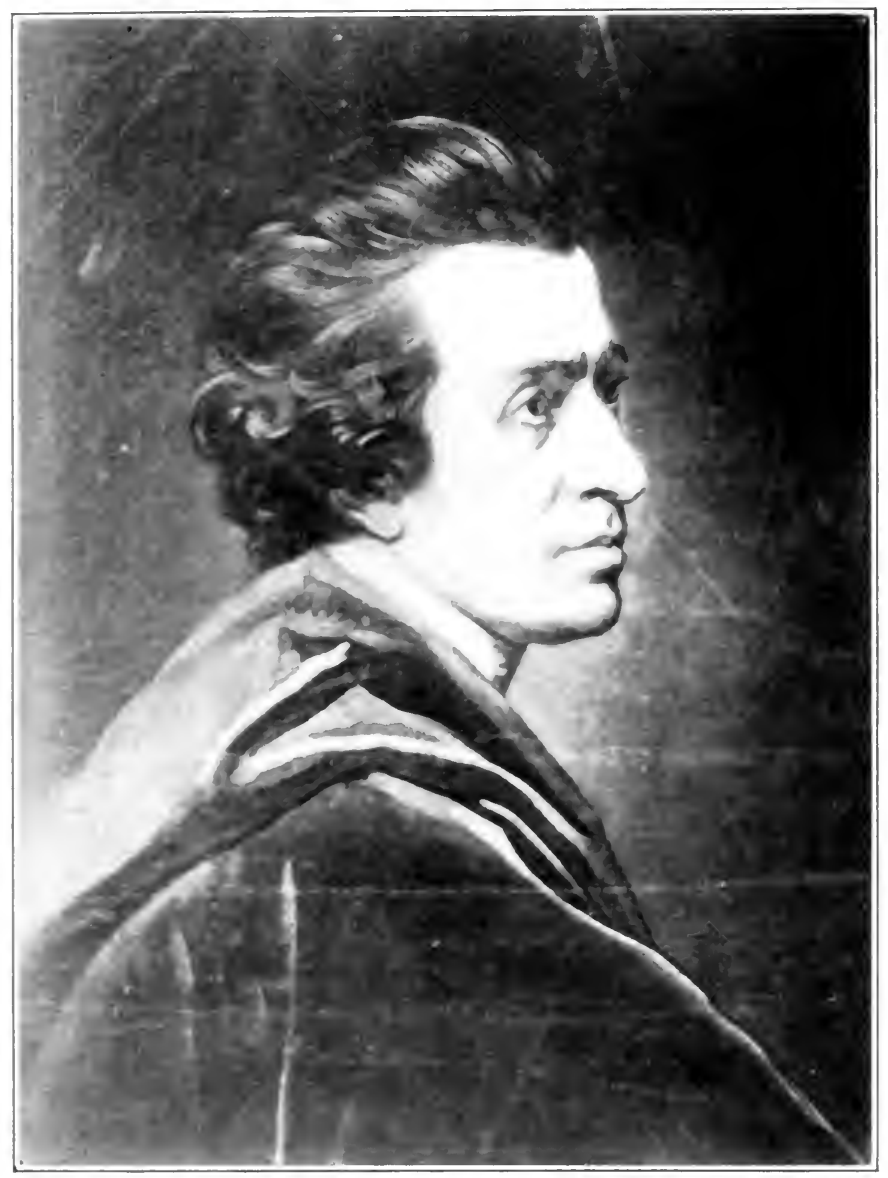

RICHARI) C(YMBERLANI)

FROM A PAINTING BY ROMNEY 

that motherly good lady is sitting, and this worthy gentleman in the scarlet waistcoat is doubtless a very excellent subject to the state I mean, (if all these are his children) but not for your art, Mr. Romney, if you mean to pursue it with that success, which I hope will attend you-.", The modest artist took the hint, as it was meant in good part, and turned his family with their faces to the wall. Of Cumberland's portrait 'Garrick observed: "That is very like my friend, and that blue coat with a red cape is very like the coat he has on, but you must give him something to do; put a pen in his hand, a paper on his table, and make him a poet; if you can once set him down well to his writing, who knows but in time he may write something in your praise." ${ }_{21}$

Others of more stable judgment than Walpole's thought Cumberland's influence of great aid to the painter. In regard to Romney's success and Cumberland's patronage of him, " "See Madam," said Dr. Johnson, laughing, "what it is to have the favour of a literary man! I think I have had no hero a great while. Dr. Goldsmith was my last; but I have had none since his time till my little Burney came." ',22

Cumberland's influence meant much to Romney in society; the dramatist was now seen everywhere. In a letter to Garrick he describes a typical evening: 'I have,' he says, 'been four hours on my legs in the Drawingroom, which was as full as loyalty could cram it; the women were charmingly dressed, and so uniform in their

21 " "Sallies such as these," says Allan Cunningham, "sank deep into the mind of Romney: he was extremely sensitive; a piece of captious criticism, a touch of smart wit, or even a little humourous raillery, damped and disconcerted him, and paralysed his hand in whatever he was engaged on."' See Chamberlain, George Romney, 53.

22 Diary and Letters of Madame D'Arblay, Dobson ed., 1.132. 
style, that you would have sworn they had all been equipped by the hands of one and the same milliner; not a feather in the Court, but as fine as could be; how amazingly has that taste advanced in my time, which has no very long retrospect. The men were in general plain and under-dressed; the richest habit at Court was Lady Warwick's: Sir George Warren had his order snatched off his ribbon, encircled with diamonds to the value of 700£. Foote was there, and lays it upon the parsons, having secured (as he says) his gold box in his waistcoatpocket upon seeing so many black gowns in the room. The dramatic literati and the American refugees made a large corps. The King and Queen both spoke particularly long to Mrs. Montagu. Mr. Colman was there, and I had an opportunity of thanking him for a copy of his dramatic works in four volumes, newly printed by Beckett; the present surprised and at the same pleased me, because I understood he is author of a very clever copy of verses entitled Bath, \&c in which I am honoured with a satirical couplet; and it pleased me,' he concludes, with a sense of his own shortcomings, 'because peace is become so valuable and so necessary to my composition, that I cannot endure a face of hostility on a human pair of shoulders; nay, I have not even nerves to quarrel with my dog. ${ }^{23}$

In the same letter Cumberland rejoices loyally in good news from America, whose rebellion intensely angered him: 'Every ship that comes from the continent of America brings tidings of comfort; we have letters which inform us of a great defection in the colony of Georgia from the banner of rebellion; three entire companies laid their arms and submitted. Bullick, the rebel governor

23 Private Correspondence of David Garrick, 2.206-7. 
of Georgia, with a number of converts to loyalty, signed a petition to the King for Mercy, and signified their submission. This is a pin out of the scaffold, and the whole edifice of revolt seems tottering to its fall.'

It is easy to imagine the gay, social Garrick and Cumberland, a popular diner-out because of his conversational powers, calling together on their friends. The story of the visit to Romney has a parallel in a call upon Foote. The mimic had entertained them at dinner, and during a walk in the garden favoured them with a reading from a rough draft of The Maid of Bath, a play for which Cumberland subsequently furnished the epilogue. ${ }^{24}$

Cumberland tells of the nearly impossible, the humbling of Foote. Sir Robert Fletcher, a fourth at dinner, having left betimes, hid behind a screen. 'Foote, supposing his guest gone, instantly began to play off his ridicule at the expense of his departed guest. I must confess it was a way that he had, and just now a very unlucky way, for Sir Robert bolting from behind the screen, cried out-"I am not gone, Foote; spare me till I am out of hearing; and now with your leave I will stay till these gentlemen depart, and then you shall amuse me at their cost, as you have amused them at mine." Garrick alone saved the situation. 'I never saw him,' says Cumberland admiringly, 'in a more amiable light; the infinite address and ingenuity, that he exhibited in softening the enraged guest, and reconciling him to pass over an affront . . . were the most comic and the most complete

${ }^{24}$ These verses have the true Cumberland moral tone:

For in these rank luxuriant times, there needs

Some strong bold hand to pluck the noxious weeds.

The rake of sixty, crippled hand and knee,

Who sins in claret and repents on tea.

See Works of Samuel Foote, Bee ed., 3.178. 
I ever witnessed. Why was not James Boswell present to have recorded the dialogue and the actions of the scene? . . . I hope Foote was very grateful, but when a man has been completely humbled, he is not very fond of recollecting it.'

Since Foote spared no one who offended him, it is unlikely that Cumberland was upon agreeable terms with him. Davies asserts ironically that Cumberland converted Foote to the Christian faith. 'Good Christians do not know,' he says, 'what obligations they owe Mr. Cumberland. By the power of his eloquence, and the strength of his arguments, he converted, some time before his death, that wicked unbeliever, Samuel Foote to the Christian faith; he assured his friends, that if he had lived a little longer, he did not doubt but he should have completed his work, and made an honest man of him. ${ }^{25}$

If Cumberland maintained friendship with Foote, it was unusual, for amity between his brother dramatists and himself was notably lacking. In particular was there unpleasantness with the opponents of sentimental comedy. Oliver Goldsmith had watched the rise of this form of drama with mingled amusement and concern, and sought earnestly to restore the more vigorous and natural forms of play-writing. Goldsmith's unaffected dislike of sentimental drama appears everywhere in his prose. In one or two passages of his celebrated essay on the subject it is not unlikely that the author is thinking of the leader of the school, and his rival, Cumberland. 'There is,' he says, 'one argument in favor of sentimental comedy, which will keep it on the stage, in spite of all that can be said against it. It is, of all others the most easily written.

${ }^{25}$ Memoirs of the Life of David Garrick, 1.189. Davies hated both Foote and Cumberland. 
. . . It is only sufficient to raise the characters a little; to deck out the hero with a ribbon, or give the heroine a title; then to put an insipid dialogue without character or humor into their mouths, give them mighty good hearts, very fine clothes, furnish a new set of scenes, make a pathetic scene or two, with a sprinkling of tender melancholy conversation throughout the whole, and there is no doubt but all the ladies will cry, and all the gentlemen applaud. ${ }^{\prime 28}$

Whether professional rivalry was increased by personal antagonism cannot be definitely known. The two dramatists first met at the British Coffee-House, and must have seen each other often among the famous group which gathered at this place of wit and literary cheer. Intercourse between two such diffident and sensitive men could not have been easy, and numerous stories have survived of unlucky contretemps. Northcote tells us that if Cumberland 'had gone in the room, Goldsmith would have flown out of it as though a dragon had been there.'27 $\mathrm{He}$ subsequently adds: 'It was not till his life was about to close that he became tolerant of the condescending attentions of the fretful Cumberland. ${ }^{28}$

To Goldsmith, Richard Cumberland must have seemed an embodiment of all that was vitiating in English drama. With the success of Hugh Kelly and Cumberland, the passion for sentimental comedy had assumed almost a religious fervour. A numerous following of sentimental writers had gathered about Cumberland, of whom he was the undisputed leader. Elizabeth Griffith was then a 'successful writer'; Charlotte Lennox, the

${ }^{26}$ The Good Natured Man and She Stoops to Conquer, Dobson ed., 125-30.

27 Hazlitt, Conversations of James Northcote, 275.

28 Forster, Life of Goldsmith, 406. 
American, was enjoying the prestige which the friendship of Doctor Johnson and her saccharine drama, The Sister, had given her; and William O'Brien, the actor, wrote sentimental adaptations from the French. But however much Goldsmith despised Cumberland's dramatic ideals, he did not underestimate his rival's powers. 'Goldsmith was now conscious,' says Forster, 'of an opponent in the author of The West Indian, who challenged his utmost exertion; and, eager again to make it in behalf of the merriment, humor, and character of the good old school of comedy (Colman so far encouraged his purpose, as to revive the Good Natured Man for a night or two during the reign of The West Indian), withdrew to the quiet of a country lodging to pursue his labors undisturbed.' ${ }^{29}$ Goldsmith returned with She Stoops to Conquer, 'designed,' said the critics, 'to run down the sentimental slip-slop, that . . . had infected the stage.' The success of the new play was immediate and almost unqualified. Sentimental comedy had received a dangerous wound. Such a shout as shook the theatre on the first night, when Tony Lumpkin and his friends were gathered at the Jolly Pigeons, might well have kindled a less inflammable jealousy than Richard Cumberland's, and accounts, by all the laws of human nature, for a certain story of She Stoops to Conquer, in the Memoirs.

Cumberland says he was present when She Stoops to Conquer was christened by Goldsmith: 'He dined with us as a visitor, introduced as I think, by Sir Joshua Reynolds, and we held a consultation upon the naming of his comedy, which some of the company had read, and which he detailed to the rest after his manner, with a great deal

29 Forster, Life of Goldsmith, 380. 
of humor. Somebody suggested-She Stoops to Conquer - and that title was agreed upon.' Here the writer of the Memoirs lapses into condescension. In the light of what posterity has meted out to each dramatist, his patronage of Goldsmith has an amusing aspect. 'When,' he says, 'I perceived an embarrassment in his manner towards me, which I could readily account for, I lost no time to put him at his ease, and I flatter myself I was successful. As my heart was ever warm towards my contemporaries, I did not counterfeit, but really felt a cordial interest in his behalf, and I had soon the pleasure to perceive that he credited me for my sincerity- "You and I," said he, "have very different motives for resorting to the stage. I write for money, and care little about fame-" I was touched by this melancholy confession, and from that moment busied myself assiduously amongst all my connexions in his cause.'

The tale told by Cumberland of the first night of the play has given all the biographers of Goldsmith a useful weapon against the veracity of the sentimental dramatist. The objections to the production of She Stoops to Conquer, Cumberland writes, were numerous, but Colman was at length overborne by Johnson, and the 'eccentric production' was given a stage. Cumberland, who pictures Goldsmith's friends as earnestly fighting for a forlorn hope, describes the dinner at the Shakespeare Tavern before the play, with Johnson as the leader of 'a phalanx of North-British predetermined applauders.' The conduct of the party at the theatre was regulated as if for a difficult campaign. 'We had amongst us,' says Cumberland, 'a very worthy and efficient member . . . Adam Drummond, of amiable memory, who was gifted by nature with the most sonorous, and at the same time 
the most contagious, laugh, that ever echoed from the human lungs. The neighing of the horse of the son of Hytaspes was a whisper to it; the whole thunder of the theatre could not drown it. This kind and ingenuous friend fairly forewarned us that he knew no more when to give his fire than the cannon did, that was planted on a battery. He desired therefore to have a flapper at his elbow, and I had the honour to be deputed to that office.' So hearty was the laughter, according to Cumberland, that She Stoops to Conquer became almost a 'secondary object.' 'But we carried our play through,' he concludes, 'and triumphed not only over Colman's judgment, but our own.'

Forster and Prior reply bitterly to this story. Forster declares that Cumberland has described a 'jumble of a party, ${ }^{30}$ that could never have been got together, a proof being the mention of Fitzherbert who was already dead; that he has 'unblushingly mis-stated the known opinions of Johnson and the rest in connection with the play'; and that 'it is Sir Fretful good-humouredly describing the success of a brother dramatist.' Forster also says that the papers of the next day report Cumberland 'to have been seen as manifestly miserable.' Prior denies, with a show of evidence, the truth of Cumberland's story, and thinks it unlikely that a rival of Goldsmith's should be of the party planning the play's success.

It was natural that stories should gather about the leaders of the sentimental school whose hopes were somewhat dampened by the success of She Stoops to Conquer. Cumberland is described as 'looking glum,' ${ }^{31}$ and a hiss

${ }^{30}$ Forster, Life of Goldsmith, 416.

31 Moore, Life of Oliver Goldsmith, 407. 
was attributed in turn to Cumberland, Kelly, and Macpherson..$^{32}$ The following travesty of the supposed fate of the writers of sentimental comedy was published in the papers of the day: 'On Monday, between the hours of six and nine in the evening, Miss Sententia HornBook, a young lady particularly known at the theatre, was suddenly taken ill and her life is despaired of. Her friends, who during the course of her short existence, have been perpetually crying about her, will probably say on this occasion like Laertes,

Too much of water hast thou had, Ophelia, And therefore I forbid my tears.

This sudden calamity is said to have been brought on by the prescription of one Dr. Goldsmith, a name which we do not recollect to have met with in the list of those who destroy either with or without a license. Mr. $\mathrm{C} \longrightarrow \mathrm{d}, \mathrm{Mr} . \mathrm{K} \longrightarrow \mathrm{y},{ }^{33} \mathrm{Mrs} . \mathrm{G}-\mathrm{hs},{ }^{34} \mathrm{Mrs}$. L— $\mathrm{x},{ }^{35}$ $\mathrm{Mr} . \mathrm{O}-\mathrm{n}$ (O'Brien), ${ }^{36}$ are sending hourly to inquire after her; because when she dies, as the proverb says, they may quake for fear. On the third night of the comedy the following appeared-

32 Forster, Life of Goldsmith, 416. A story was current that Cumberland told Charlotte Lennox to hiss a rival play. See Boswell, Life of Johnson, Hill ed., 4.10, foot-note.

${ }^{33}$ Hugh Kelly, a leader of the sentimental school of drama. False Delicacy and $A$ School for Wives are comedies typical of Kelly.

${ }^{34}$ Probably Elizabeth Griffith. She wrote seven plays, all of a sentimental character.

35 Charlotte Lennox, born in America, author of various poems, novels, and plays.

${ }^{36}$ William O'Brien, an actor of note, and author of Cross Purposes and The Rival, both adaptations from the French. 
At Dr. Goldsmith's merry play, All the spectators laugh, they say;

The assertion, Sir, I must deny,

For Cumberland and Kelly cry. Ride, si sapis. ${ }^{37}$

By all evidence it must be admitted that the balance swings away from truthfulness and generosity in Cumberland. The testimony of Prior and Northcote cannot be disregarded. Cumberland, moreover, ignores the marked success of She Stoops to Conquer; the tone of his narrative is too complacent, were Goldsmith the humblest of dramatists. The whole matter may be best understood by remembering that Goldsmith and Cumberland were rivals in the two bitterly contending forms of comedy.

No lover of the literary circle of the' eighteenth century can fail to regard Goldsmith's Retaliation with gratitude. By it personalities are illumined as nowhere else save in the Life of Johnson. A passing foot-note has often sufficed to identify the Richard Cumberland celebrated in the poem. He was, we are told, the author of The West Indian. But so delicate, so penetrating a bit of portraiture as Goldsmith has bestowed upon his rival, is worthy of more observation. Let us listen to Cumberland's own eulogium. Into it he has infused much of his nature,-his kindliness, his ambition, and his vanity:

'As the life of poor Oliver Goldsmith was now fast aproaching to its period, I conclude my account of him with gratitude for the epitaph he bestowed on me in his poem called Retaliation. It was upon a proposal started by Edmund Burke, that a party of friends, who had dined 37 Prior, Life of Goldsmith, 2.398. 
together at Sir Joshua Reynolds' and my house, should meet at the St. James Coffee-House, which accordingly took place, and was occasionally repeated with much festivity and good fellowship. Dr. Barnard, Dean of Derry, ${ }^{38}$ a very amiable and old friend of mine, Dr. Douglas, since Bishop of Salisbury, Johnson, David Garrick, Sir Joshua Reynolds, Oliver Goldsmith, Edmund and Richard ${ }^{39}$ Burke, Hickey, ${ }^{40}$ Whiteford, ${ }^{41}$ with two or three others constituted our party. At one of these meetings an idea was suggested, of extemporary epitaphs upon the parties present; pen and ink were called for, and Garrick off hand wrote an epitaph with a good deal of humour upon poor Goldsmith, who was the first in jest, as he proved to be in reality, that we committed to the grave. The dean also gave him an epitaph, and Sir Joshua illuminated the dean's verses with a sketch of his bust in pen and ink inimitably caricatured. Neither Johnson, nor Burke wrote any thing, and when I perceived Oliver was rather sore, and seemed to watch me with that kind of attention, which indicated his expectation of something in the same kind of burlesque with their's, I though it time to press the joke no further, and wrote a few couplets at a side table, which when I had finished and was called up by the company to exhibit, Goldsmith with much agitation besought me to spare him,

38 Thomas Barnard, successively Dean of Derry, 1774, Bishop of Killaloe, 1782, and Bishop of Limerick, 1794.

${ }^{39}$ A younger brother of Edmund Burke.

40 'Honest Tom Hickey,' an Irish lawyer.

41 Caleb Whitefoord, a diplomatist. He was noted for his wit. See Retaliation and Wilkie, Letter of Introduction. At the Retaliation party, Whiteford wrote two epitaphs at the expense of Goldsmith and Cumberland, with which they were both so displeased that he did not attend at the next meeting. He addressed an apology in verse to Reynolds. See Northcote's Memoirs of Sir Joshua Reynolds, Philadelphia, 1817, 106-7. 
and I was about to tear them, when Johnson wrested them out of my hand, and in a loud voice read them at the table. I have now lost all recollection of them, and in fact they were little worth remembering, but as they were serious and complimentary, the effect they had upon Goldsmith was the more pleasing for being so entirely unexpected. The concluding line, which is the only one I can call to mind, was-

All mourn the poet, I lament the man-

This I recollect, because he repeated it several times, and seemed much gratified by it. At our next meeting he produced his epitaphs as they stand in the little posthumous poem above-mentioned, and this was the last time he ever enjoyed the company of his friends.'

Such is Cumberland's account of Retaliation. $\mathrm{He}$ refers to Goldsmith slightingly; he characterizes Retaliation as 'the little posthumous poem'; and he gives no hint that he saw an ironical meaning in the lines. Was it possible that he thought Goldsmith reverenced him as 'The Terence of England, the mender of hearts'? Did he believe the poet wholly ingenuous when he heard Retaliation reach its climax in the lines:

Say was it that vainly directing his crew

To find out men's virtues, and finding them few,

Quite sick of pursuing each troublesome elf,

He grew lazy at last and drew from himself?

It would seem that this answer to the question should be an unconditional no. Yet there is reason to believe that Cumberland thought the lines unalloyed gold. He may have felt that his soft verses of the previous meeting had disarmed his rival; his own sense of superiority to Goldsmith may not have allowed him to doubt of the 
latter's attitude towards himself. His acknowledgment 'with gratitude' to Goldsmith, in the Memoirs, has been pointed out by the latter's biographers as a supreme example of Cumberland's vanity, and blindness to raillery. 'Had Cumberland seen through Retaliation,' says Moore, 'he would not have been so generous in his subsequent references to Goldsmith. During the thirty-five years that lapsed between the publication of the lines and his death the news had not reached him that they were not to be taken seriously. ${ }^{\$ 2}$ So Forster declares that Cumberland was in reality gravely grateful to Goldsmith for having laughed at him, ${ }^{43}$ and Mrs. Thrale says that Cumberland alone of all the world did not realize the import of the lines. ${ }^{44}$ That the verses are ironical, most readers will agree. The interpretation of them as the subtlest satire is too just, too satisfactory, to be imaginative. But that Cumberland, in egregious vanity, accepted the poem as an accurate portrait of himself is by no means certain. Fanny Burney believed the lines to be a good sketch of Cumberland's benevolent and kindly side. It is conceivable that Cumberland, perceiving the ironical interpretation of the poem, chose to read no malice into it, but accepted it along with the portraits of Garrick and the others, as a kindly outline sharply touched with the writer's wit, but concealing no real venom. As for Moore's statement that Cumberland's kindness to Goldsmith in the Memoirs proves his blindness to the meaning of the lines, it may be said that Goldsmith is by no means handled gently by Cumberland. His account of the first night of She Stoops to Conquer can hardly be called kindly, and his criticism ${ }^{42}$ Life of Goldsmith, 226.

43 Ibid., 380.

${ }^{44}$ Boaden, Memoirs of the Life of John Philip Kemble, 1825 ed., 1.369. 
of Goldsmith's non-dramatic work is just, but hardly fulsome.

Cumberland's 'gratitude' to Goldsmith must have persisted, for in The Gentleman's Magazine for August, I778, we find his Poetical Epistle to Dr. Goldsmith, or Supplement to his 'Retaliation.' This poem is a rather unfortunate effort. It lacks wit, and its language is in the authour's most pompous vein:

Doctor, according to our wishes, You've character'd us all in dishes,

Served up a sentimental treat,

Or various emblematic meat.

And now it's time, I trust, you'll think

Your company should have some drink.

Douglas, 'fraught with learned stock,' Johnson, 'with melting heart but look austere,' 'dear Garrick,' Burke, Barnard, and the others are all celebrated. The lines to Reynolds, which Northcote says 'certainly savour much of their author,' follow:

Pour forth to Reynolds without stint

Rich Burgundy of ruby tint;

If e'en his colors chance to fade

This brilliant hue shall come in aid,

With ruddy light refresh the faces,

And warm the bosoms of the Graces.

The poem ends with the lines to Goldsmith:

Now, Doctor, you're an honest sticker,

So take your glass, and choose your liquor.

Wilt have it steep'd in Alpine snows,

Or damask'd at Silenus' nose?

With Wakefield's Vicar sip your tea

Or to Thalia drink with me? 
Retaliation and its supplement also brought from Dean Barnard more verses addressed To Oliver Goldsmith and Richard Cumberland:

Dear Noll and dear Dick, since you've made us so merry, Accept the best thanks of the poor Dean of Derry! Though I here must confess that your meat and your wine Are not to my taste, though they're both very fine;

For Sherry's a liquor monastic, you own-

Now there's nothing I hate so as drinking alone:

It may do for your Monks, or your Curates and Vicars, But for my part, I'm fond of more sociable liquors.

Your Ven'son's delicious, though too sweet your sauce is Sed non ego maculis offendar paucis

So soon as you please you may serve me a dish up,

But instead of your Sherry, pray make me a-Bishop.

Verbiage as all this was, it brought Cumberland into closer touch with Goldsmith. He could not fail to recognize, to some degree, the poet's genius, and when the latter did not encroach upon the drama, Cumberland was mildly appreciative. 'There is,' Cumberland says, 'something in Goldsmith's prose, that to my ear is uncommonly sweet and harmonious; it is clear, simple, easy to be understood; we never want to read his period twice over except for the pleasure it bestows; obscurity never calls us back to a repetition of it.' Cumberland denied, however, that Goldsmith was a real poet on the ground that he had written no poem which might be called a magnificent whole.' 'The Deserted Village, Traveller and Hermit,' he writes, are 'all specimens beautiful as such, but they are only birds' eggs on a string, and eggs of small birds too.' 'I remember him,' says Cumberland, 'when in his chamber in the Temple, he shewed me 
the beginning of his Animated Nature; ${ }^{45}$ it was with a sigh, such as genius draws, when hard necessity diverts it from its bent to drudge for bread.' In his story of the Vicar of Wakefield, as he had it from Johnson, Cumberland pictured Goldsmith in danger of being compelled to marry his landlady to square a debt of a few pounds, until Johnson luckily examined the manuscript of the novel. This Prior declares apocryphal, and says that Cumberland misrepresents 'the sum received for it, and even what every one of common knowledge on literary matters knew the name of the bookseller to whom sold.' ${ }^{46}$

Cumberland closes his account of Goldsmith in the same vein of kindly tolerance: 'Goldsmith had the joy of finding his ingenious work succeed beyond his hopes, and from that time began to place a confidence in the resources of his talents, which thenceforward enabled him to keep his station in society, and cultivate the friendship of many eminent persons, who, whilst they smiled at his eccentricities, esteemed him for his genius and good qualities.' It is difficult to endure this tone of Cumberland's, but it should be remembered that posterity had not yet decreed immortality for Goldsmith. Cumberland erred with the rest of the age in not realizing fully the quality of Goldsmith's genius.

45 See Gibbs, Works of Goldsmith, 1.31, foot-note.

${ }^{46}$ Prior, Life of Goldsmith, 2.396. See also Wyndham, Annals of Covent Garden, 1.187, 193. 


\section{CHAPTER VIII}

\section{DRAMATIC ACHIEVEMENT (Continued).- SHERIDAN.-DEATH OF \\ GARRICK}

IN I775 George Sackville Germain, first Viscount 1 Sackvilie, had been declared Secretary of State for the colonies. Soon afterwards, Cumberland was appointed Secretary of the Board of Trade by Sackville, and 'was . . . introduced to the commencement of a friendship, which day by day improved, and which no word or action of his life to come ever for an instant interrupted or diminished.' While with Sackville, Cumberland met Rodney, and believed himself the indirect cause of the admiral's rise. He saw Rodney plan the ruin of the French fleet in manoeuvres with 'a parcel of cherry stones,' and heard him swear vehemently that he would lay the French admiral's flag at his sovereign's feet.

The dramatist was now the head of a large family, and his home life was all that could be wished. If he was 'gey ill to live with' abroad, he was at least a devoted husband and a loyal father. Richard, the eldest son, after a satisfactory career at Westminster, had entered Trinity College, Cambridge, but had later enrolled himself in the first regiment of foot-guards. The second and fourth sons, George and William, had sailed for America. Charles, the third son, was a member of the tenth regiment. Cumberland was proud of his daughters. 'The two young ladies,' wrote their cousin, George 
Cumberland, to his brother, 'are amazingly grown, but Mrs. Cumberland younger and handsomer than either of them.'1

Meanwhile Cumberland wrote for the stage, and passed many hours of the day with the great to whose society he had now ready access. Yet in all the scattered records of these days how difficult it is to find a friendship unmarred by the strange irritability by which we come to recognize Cumberland! Garrick, his first and most valued friend, is now impatient with him; Goldsmith, as has been seen, cannot endure him; and his old school-fellow, George Colman, now hates him with unswerving cordiality. In the few years immediately following the début of The West Indian he had gained the ill will of one who had hitherto only regarded him with amusement. On some unlucky occasion he had ventured to inform Horace Walpole of his dislike for Thomas Gray. This aversion Cumberland did not see fit to conceal, even from the elegist's nearest friend, and it appears throughout his writings. He has completed scarce a score of pages of the Memoirs before he smiles at a 'meagre collection of odes by Gray, the most costive of poets.' Even flattery bestowed by the poet upon his uncle Bentley's drama, Philodamus, was 'outrageously pedantic,' and the dignity of Retrospection, a genuine poem, is blurred by an ill-timed and weak criticism of Gray's verse. Cumberland's tactlessness had won him an implacable enemy.

'Mr. Cumberland, the maker of plays,' sneers Walpole, in a letter to Mason, 'told me lately, it was pity, Gray's letters were printed; they had disappointed him so much.' Cumberland had now ceased to be, with the rest

1 The Cumberland Letters, 160. 
of the world, a passive offender. 'No doubt,' Walpole adds, 'he likes Sterne's, and Shenstone's, and Lady Luxborough's.' Mason's reply fanned the flame: 'I admire Mr. Cumberland's rudeness to you exceedingly, for to condemn Gray's letters to you who had contributed so much to the collection was worse than if he had condemned them to the editor. The editor might be excused in printing bad letters out of defence and respect to those who furnished him with them. The contributors to such a collection could have no such plea, but more than enough of this poor man, let him go on with his sentimental comedies, this anecdote shews he is qualified for the task, because it shews he can have no feeling. Taste in all cases is out of the question.'

A month after the unlucky talk Walpole's rancour was still active. 'I felt,' he writes again to Mason, 'Mr. Cumberland's folly so much, that his impertinence was lost on me. He has written an ode, as he modestly calls it in praise of Gray's odes-charitably no doubt to make the latter taken notice of. Garrick read it tother night at Mr. Beauclerc's, who comprehended so little what it was about, that he desired Garrick to read it backwards, and try if it would not be equally good; he did and it was.' ${ }^{4}$

Careless words secured enmity for Cumberland, but theatrical enterprises plunged him into an abyss of diff-

${ }^{2}$ Letters of Horace $W$ alpole, Toynbee ed., 9.288.

3 Correspondence of Horace Walpole and William Mason, Mitford ed., 1.219 .

${ }^{4}$ Ibid., 9.306. It was to this reading backwards that Dean Barnard alluded in his verses-

The art of pleasing, teach me, Garrick;

Thou who reversest odes Pindaric

A second time read o'er. 
culties. He had long planned to write a tragedy, a species of dramatic composition in which he did not excel, upon an English subject. By the fall of 1776 was completed The Battle of Hastings. In September the play was offered to the Covent Garden management, but was refused. Cumberland's disappointment was keen, and he remained unsatisfied with the verdict. $\mathrm{He}$ appealed to Colman for a reading of the tragedy. 'I ask you,' he writes, 'as a scholar and author of genius, to read and judge my piece. . . . I have not presumption enough on my own behalf,' he adds in his most humble tone, 'to say that they are not warranted in what they have done, neither am I attempting to traverse any right which is in them, and which they may properly exercise.' Nevertheless, Cumberland protests that he 'was denied an appeal by the very gentleman, who not a week before had exhibited "The Man of Reason." 'My tragedy,' he says, 'cost me great pains and much attention; hath been many years in hand; is entirely original in plan, popular in its subject, and free of all imitation.' Having praised his own play, Cumberland attacks his enemies: 'The opinion of men exceedingly high in the republic of letters,' he boasts, 'have been unanimous, and more than warmly, in its favour. You will not wonder, if such authority makes me hesitate about acquiescing under the veto of a junta of proprietors, whose education has not started with the Muses, and whose habits have been little calculated to make them critics in literature. I should add that my piece was accepted by Mr. Garrick, and had a place, for this season, but was withdrawn by me for reasons not worth troubling you with. ${ }^{6}$

5 Kelly's Man of Reason was acted at Covent Garden in 1776.

6 Peake, Memoirs of the Colman Family, 1.417-8. 
This was a weak letter, and gained nothing but evasion from the tactful Colman. Behind the screen of a past quarrel with the Covent Garden management he declined to read the play, and urged Cumberland to rest satisfied with the good opinions which he had already had. $\mathrm{He}$ refused to read the play on the rather slight ground that he, too, was at odds with Covent Garden. 'My suffrage,' so ran his reply, 'in favour of your tragedy would rather be ascribed to motives of ill will to them, than a love of justice, and a laudable zeal for the honour of literature. There is not another man so peculiarly situated. I flatter myself, therefore, that you will, on these considerations, excuse my declining to read and judge of your tragedy, whose merits may be rested so much more confidently on the testimony of those respectable opinions which you have already collected.'

Although Garrick had already retired from the stage, he was evidently persuaded by Cumberland to interest himself in The Battle of Hastings. Universal menderof-plays as he was, he corrected, revised, and amended until Cumberland mustered courage to present the play to Sheridan, then the newly made manager of Drury Lane Theatre. It is said that the leader of sentimental comedy was introduced to Sheridan by a letter from Garrick. Soon we learn of Cumberland's begging the new manager to stage his tragedy.

Sheridan's facile genius was not yet at its height, but youth, consciousness of great powers, and a capricious temperament, made him rule Drury Lane without mercy. His treatment of Cumberland exhibits the arrogance of a dictator. A number of letters exist,

7 Peake, Memoirs of the Colman Family, 1.419.

${ }^{8}$ Posthumous Letters to Francis Colman, and George Colman, the Eldier, 223. 
showing the lengths to which Cumberland went to obtain a hearing for his new play. The first of these is an humble one, asking Sheridan to give the tragedy his consideration. 'I ought and should have despaired of its merits,' writes Cumberland, 'if I had not had a pretty long and intimate acquaintance with the stage, and what produces stage effect; if I had not given infinite pains and attention to this composition for many years; and, above all, if I had not been supported by the unanimous suffrages of every person to whose judgment I have committed it.' After this account of the tragedy, Cumberland says, with abjectness enough to satisfy the most tyrannical manager, and with an offer to dispense with the honorarium: 'I beseech you, therefore, Sir, to read it with as much malice as you are capable of, considering that an author is an ill judge in his own cause.'

To this epistle Sheridan did not apparently reply. The evasive Colman had asked about the fate of the tragedy, and Cumberland says: 'I was forced to add, that having written a letter on Friday se'nnight to Mr. Sheridan in the most candid and fair terms I could devise, he had not to this moment acknowledged the receipt of it. ${ }^{10}$ At this treatment Cumberland's irritation showed through his customary veneer of politeness. 'We both agreed,' he says referring to Sheridan, 'that such a conduct must be altered, or it would operate to his ruin. . . . My experience with the world assures me that there is no man who can keep his place in the good will and esteem of those he has to deal with, if he so totally throws off the forms of politeness. ${ }^{11}$ Cumberland was assuredly in the right, and Fitzgerald, in his Lives of the Sheridans, con-

${ }^{9}$ Fitzgerald, Lives of the Sheridans, 1.156, foot-note.

10 Ibid., 1.155, foot-note.

11 Ibid., 1.156, foot-note. 
victs Sheridan of unpardonable rudeness in his treatment of the playwright. ${ }^{12}$

In the end Sheridan accepted the play. Then followed a tumultuous season of rehearsal and preparation. Sheridan loathed the heavy tragedy; the performers had no confidence in it; and Garrick regretted his intercession. Under the actor's pen, revision and deletion continued. We have Cumberland's piqued thanks for Garrick's candid opinion of an epilogue. The author encloses another, fortified with a host of apologies. It was written, he swears, 'post-haste directly upon reading Garrick's letter.' For other suggestions from his friend the dramatist is eternally grateful. Meanwhile Sheridan's cool insolence tortures Cumberland, and the entire correspondence reflects the perturbed nerves of all connected with the unfortunate play. Although he boasts of its submission, the dramatist's temper hangs by a thread: 'We have,' he writes Garrick, 'as yet had no rehearsal, nor can I tell when we shall. . . . Without some prudence and patience I should never have got the ladies cordially into their business, nor should I not only have avoided a jar with Mr. Smith, but so far have impressed him in my favour as to draw an offer from him (though too late) of taking the part of Edwin.' A petulant postscript adds: 'No news whatever. Pray burn the copy of my epilogue. ${ }^{13}$

Sheridan's indifference to Cumberland and to his tragedies is clear in a letter from the latter to Garrick: 'I read,' writes Cumberland, 'the tragedy in the ears of the performers on Friday morning; I was highly flattered by my audience, but your successor in management is not a representative of your polite attention to authors on

12 Fitzgerald, Lives of the Sheridans, 1.156.

${ }^{13}$ Private Correspondence of David Garrick, 2.283. 
such occasions, for he came in yawning at the fifth act, with no other apology than having sate up two nights running. ${ }^{14}$ Garrick has evidently cautioned Cumberland against offending Sheridan, for Cumberland writes with some complacence: 'Thank you for your advice; I persuade myself I have anticipated it, and shall certainly not lose the battle for want of temper. ${ }^{15}$ On another day he has "called . . . on Mr. Sheridan and quickened him, but all in good humor and perfect harmony.' ${ }^{16}$ A letter, written presumably the next evening, is still more hopeful: 'I have this morning, my dear friend, rehearsed the "Battle," and a brave battle we made. Madam Yates rehearsed without book her whole part; all was harmony, zeal, and good will: nothing lagged or hobbled in the whole; and the new corrections (especially the finale to the fourth act) were applauded. The fifth act, which was long, is now very brilliant, and I am well contented to take my trial. ${ }^{17}$

Since Garrick had formed The Battle of Hastings, this turn for the better must have pleased him. It is certain that he was interested in The Battle of Hastings, but whether from real belief in its worth, or from a desire to befriend Cumberland, is uncertain. 'It has been said,' remarks Davies, 'that Mr. Garrick, after he had left the stage, recommended the Battle of Hastings to $\mathrm{Mr}$. Sheridan with great warmth, from an earnest desire to oblige the author, who, on this occasion did not seem to have a proper sense of Mr. Garrick's friendship. . . .' The patron was noncommittal in expressing an opinion of the play: 'Mr. Garrick was asked by several persons

14 Private Correspondence of David Garrick, 2.285.

15 Ibid., 2.283.

16 Ibid., 2.284 .

17 Ibid., 2.286 . 
his judgment of that tragedy; his constant answer was, Sir, what all the world says, must be true. No explanation of his meaning could be drawn from him. ${ }^{18}$ It is, in all events, clear that Garrick was disgusted with the correspondence relative to The Battle of Hastings, for we find at the end of this a bit of damning evidence: 'Endorsed, Mr. Cumberland's letters to me when at Althorp, in Dec. I 777, about "The Battle of Hastings;" -a true picture of the man. ${ }^{19}$

So the weeks passed, and, more than two years after it was written, on January 24, I778, at Drury Lane Theatre, The Battle of Hastings was acted. It had been ushered into the world only by the persistence of Cumberland; Sheridan and Garrick stood by, disgusted sponsors, disliking more than ever both the play and Cumberland himself. The play was acted twelve times, but real success was despaired of from the first. Friendly comments were few, though George Cumberland wrote his brother, Richard Denison Cumberland, that even if 'no friend to slaughter and destruction,' he thought it 'a pleasing tragedy.' ${ }^{20}$ The critique of The Town and Country Magazine for January was, perhaps, the most tolerant: 'The Battle of Hastings is very far from being a contemptible production; and, with the aid of a pruning knife . . . we hope to see it in far greater perfection.' Such tributes seem rare in the storm of universal vituperation. 'Why,' says Scot's Magazine for February, 'Mr. Cumberland has chosen to call this play The battle of Hastings, we do not see. To be sure we hear something of such a battle in the last act, but almost the whole of the tragedy consists of love-scenes between a disguised

${ }^{18}$ Memoirs of the Life of David Garrick, 2.274.

19 Ibid., 2.275.

${ }^{20}$ The Cumberland Letters, 176. 
prince, and a couple of fond maidens. The Rival Beauties would have been a more proper name for it. The French are blamed for filling their tragedies with love; Mr. Cumberland appears inclined to keep them in countenance.'

When, some thirty years before, Cumberland had given to Doctor Nicolls of Westminster a set of plagiarized verses, his school-fellows had smiled. Later the critics of The Brothers and The West Indian had discovered in these plays scenes and lines of a strongly allusive character. But in The Battle of Hastings all previous faults of this nature were transcended. The plot has echoes from all sentimental comedy, and the language is steeped in the diction of Shakespeare. Here was an opportunity for the critics to annihilate their enemy. The reviewer of The St. James Chronicle of January 20 allows himself to be satirical: 'The story is wonderful; the Incidents all calculated to startle, and the language all Daisies and Lilies and Pinks and Roses. The Slips and Roots of most of them have been stolen; but from a Garden where they will not be missed, and Author and Connoisseurs may be guilty of Stealing and not of Felony.' The London Review has many malicious references to 'Squire Cumberland.' Later commentators have been equally severe.

'The coat of Joseph,' says Biographia Dramatica, 'and the dress of Harlequin, were never composed of patchwork more general than is the style of this performance. An injudicious application of Shakespeare's phraseology throughout all parts of it, continually provokes a comparison unfavourable to our present author. Add to this, that he has grossly violated the truth of history, in his representations of Edgar Atheling and Harold. 
Under his hand they may be said to have exchanged characters. . . . It was coolly received.' 'A 'A strange incongruous business, ${ }^{122}$ says the unfriendly Dibdin, and Davies declares that 'The Battle of Hastings is what we call a Pasticio, a work made up of centos from various authors, and more particularly from Shakespeare. ${ }^{23}$

The Battle of Hastings has all the faults of bad tragedy, and is, as Doran says, 'as near Shakespeare as Ireland's Vortigern, ${ }^{24}$ a play hissed from the stage on the first night. The play fails today, as in 1778 , by any dramatic test, yet has, rising from its worst vice, one virtue. Out of long periods of stiff, impossible diction occasionally sounds the beat of sonorous and melodious verse. 'The language,' says Scott, 'often uncommonly striking, has more merit than the characters or the plot. ${ }^{25}$

The failure of The Battle of Hastings justified Sheridan's ridicule of the tragedy, and confirmed his impression of the play and of its author. His feelings towards Cumberland now verged upon hearty contempt; nor was he without resentment and anger. It is improbable that Sheridan had forgotten the sharp reflections upon his friends in Cumberland's farce, The Note of Hand; moreover, other events had increased his irritation against the dramatist to the breaking point. In his Memoirs of Sheridan Watkins says:

21 Biographia Dramatica, 3.51.

22 A Complete History of the Stage, 5.275.

23 Memoirs of the Life of David Garrick, 2.275.

${ }^{24}$ W. H. Ireland's Vortigern was an historical tragedy, appearing at Drury Lane in 1799. It was an imposition, professing to be an original tragedy of Shakespeare found in an old trunk.

${ }^{25}$ Novels of Swift, Bage and Cumberland, 'Prefatory Memoir to Richard Cumberland,' 41.

See Genest, 6.6, for a comparison of The Battle of Hastings with Boyce's Harold. 
What was the cause of the quarrel between Mr. Sheridan and Mr. Cumberland has never been clearly stated; but the generally accepted story at the time was that the former, in his capacity of manager, rejected every piece Cumberland offered at Drury Lane, which occasioned some sharp language on both sides; and as other literary persons had similar complaints against the conduct of the manager, a common concern was made of the injury, and the newspapers daily exhibited some severe criticisms upon theatrical subjects and the direction of Drury Lane. ${ }^{26}$

Sheridan's disgust with Cumberland was doubtless increased by stories of Cumberland's depreciation of The School for Scandal, when it appeared in I777. The miscellanies called Sheridaniana give the best narration of this popular, but probably apocryphal, tale of the time: "When the "School for Scandal" came out, Cumberland's children prevailed upon their father to take them to see it;-they had the stage-box-their father was seated behind them; and as the story was told by a gentleman, a friend of Sheridan's, who was close by, every time the children laughed at what was going on on the stage, he pinched them, and said, "What are you laughing at, my dear little folks? You should not laugh, my angels; there is nothing to laugh at;" and then, in an undertone, "keep still, you little dunces." Sheridan having been told of this long afterwards, said, "It was very ungrateful in Cumberland to have been displeased with his poor children for laughing at my comedy; for I went the other night to see his tragedy, and laughed at it from beginning to end." ${ }_{27}$

${ }^{26}$ Memoirs of Sheridan, 1.239.

${ }^{27}$ Sheridaniana; 67. Compare Blackwood's Magazine for February, 1826, and Oxberry, 2.32. The tragedy at which Sheridan laughed was generally supposed to be The Battle of Hastings. Mudford points out that this, Cumberland's first tragedy, was not acted until 1778. Unless 
There were many other stories of Cumberland's unhappiness at the success of The School for Scandal. A rumour reached Sheridan's ear that Cumberland had sneered at the play in the lobby of the theatre, on its first night. 'I gave my accuser proof positive,' Cumberland says, in a tone of rather loud protest, 'that I was at Bath during the time of its first run, never saw it during its first season, and exhibited my pocket-journal in confirmation of my alibi: the gentleman was convinced of my innocence, but as he had no opportunity of correcting his libel, every body that read it remains convinced of my guilt.'

Whether or not Sheridan had heard of Cumberland's 'd-d disinheriting countenance' at The School for Scandal it is evident that he was irritated at Cumberland some time before the acting of The Critic, for both dramatists were supersensitive, and it is likely that the jarring relations fomented a busy malice in Sheridan's mind, which reached its climax in the immortal Sir Fretful. ${ }^{28}$ Sheridan's desire for revenge because of real or fancied affronts admits of no doubt. 'To defend himself,' says The Westminster Magazine for November, I779, 'and to be revenged on his enemies, he has brought forth The Critick, in which he has preached, and caricatured his old Friends most outrageously.' The Critical Review for December, I779, thinks that Sheridan is 'exceedingly angry with the ministry of our theatrical world, and endeavours, though with no great dexterity, to hold them forth to the ridicule and indignation of the public.' The

Sheridan spoke of Timon, acted in 1774, or referred to a later performance of The School for Scandal, the story is factitious. The editor of Sheridaniana thinks the tragedy in question The Carmelite, acted in 1784. Michael Kelly says that Sheridan told him this story.

28 See Watkins, Memoirs of Sheridan, 1.237. 
St. James Chronicle of March 3, I779, after a review of Sheridan's dispute with certain 'play writers,' says that the author of The Critic has forgotten their flattery, and now attacks them. 'The first Act . . . is seemingly and tenderly directed at News-Papers and Criticks, but most pointedly against Dramatic Writers, who are the Authours very good friends.'

That Cumberland was the model from whom Sir Fretful Plagiary was drawn, has been the belief since the first performance of The Critic. 'Sir Fretful Plagiary,' says The Town and Country Magazine for November, I779, 'is drawn with a bold pencil, and the original may easily be traced by the striking features of the copy,' and Lloyd's Evening Post of November I, I779, calls him 'a character whose outline is so . . . drawn "that he who runs may read him!"' The Lady's Magazine for November of the same year, says: 'Sir Fretful Plagiary is soon after announced, and exhibits one of the most harsh and severe caricatures that has been attempted since the days of Aristophanes, of which a celebrated sentimental writer is evidently the object; a great part of what is said by his representative being literally taken from his usual conversation, but with very pointed and keen additions.' Watkins in his Memoirs of Sheridan declares 'that Cumberland was the principal object at whom the shaft of ridicule was directed, could not be doubted by any who were acquainted with that gentleman and his writings; and Mr. Sheridan, so far from disguising his intention in the application, took every opportunity, in public and private, of expressing his satisfaction at the mortification which it produced. ${ }^{29}$

Later critics echoed this opinion. Sir Fretful, says 29 Watkins, Memoirs of Sheridan, 1.238. 
Adolphus, '. . . was a personal representation of a wellknown living dramatist, ${ }^{30}$ and William Earle adds that 'the character of Sir Fretful Plagiary was intended as a broad satire and faithful hit upon the strange peculiarities of Richard Cumberland. ${ }^{31}$

That Sheridan was, in one or two places, thinking of his experience of The Battle of Hastings in his sketch of Sir Fretful Plagiary, can hardly be doubted. The Critic was produced but a year after the tragedy, with the history of its unhappy juggling between the two theatres, and its miserable failure, fresh in Sheridan's mind. 'I sent it to the manager of Covent Garden Theatre this morning,' says Sir Fretful of his play. If the story of Sheridan's laughter at The Battle of Hastings is true, the author of The Critic was doubtless thinking of this tragedy when he makes Sir Fretful say: 'Why, sir, for aught I know, he might take out some of the best things in my tragedy, and put them into his own comedy.' References to plagiarisms from Shakespeare would never be so likely as after familiarity with this particular tragedy. 'Your imitations of Shakespeare,' says Sneer to Sir Fretful, 'resemble the mimicry of Falstaff's page, and are about as near the standard of the original. ${ }^{32}$

It is not, however, certain that Sheridan had Cumberland exclusively in mind when he created the character.

30 Life of Bannister, 1.47. Adolphus says that the ridicule of Cumberland is not comparable to that of Dryden as Bayes, since Cumberland, 'known only by his personal virtues, his moral writings, and a few dull lines in a series of successful dramatic productions would have palled the general audience, and probably excited some indignation.' But The Public Advertiser says that if Sir Fretful is drawn from nature 'this Original certainly bids as fair for as enduring ridicule as Dryden in Bayes.'

31 Sheridan and His Times, 1.95.

32 Sheridan, The Critic, 1.1. 
In his capacity as manager, it is probable that many a tiresome playwright ruffled his nerves. At this very time he was at swords' points with Colman, and it is quite possible that the first act of The Critic satirizes types rather than individuals. The conclusion follows naturally that the sketch of Sir Fretful Plagiary may be eclectic, and that Cumberland, Colman, and their brother dramatists all contributed features for the portrait. That Cumberland was the man, says one critic, 'Sheridan has almost given his assent. ${ }^{\prime 33}$ Such a criticism virtually says to the world, 'You may call this figure Cumberland, if you wish,' and has rather the air of naming a composite photograph after its completion, than of having reproduced a definite man. 'Whether Sir Fretful Plagiary is drawn from Nature, or is only the Coinage of Fancy, we will not determine,' says The Public Advertiser of November I, I 779, and in a collection of dramatic data called The Eccentricities of John Edwin, published in I79I, occurs a passage which may approximate truth in the matter: 'The common idea that Sir FRETFUL PLAGIARY was intended as a satire on Mr. CUMBERLAND is fallacious, as no particular person was alluded to-Some of the performers imagining it was a satire on the elder COLMAN, Mr. SHERIDAN expressed a wish that it should rather be considered as a likeness of CUMBERLAND, both characters having openly affected to treat the news-paper Editors with contempt, while they secretly trembled at their power. ${ }^{134}$

Whether or not he was the original of Sir Fretful, Cumberland paid a bitter penalty for a temperament which allied him instantly to the caricature. It is said that

33 Cumberland, British Theatre, 18.

${ }^{34}$ The Eccentricities of John Edwin, 2.307. 
one of his sons was the first to recognize him, and his name is inseparably linked with a rôle which has appeared on almost every stage. His incarnation for theatre-goers by a skilful actor is best described by Boaden: 'It was perhaps reserved for Sheridan to show the utmost that Parsons could achieve, in Sir Fretful Plagiary in the Critic. I have repeatedly enjoyed this rich treat, and became sensible how painful laughter might be, when such a man as Parsons chose to throw his whole force into a character. When he stood under the castigation of Sneer, affecting to enjoy criticisms, which made him writhe in agony; when the tears were in his eyes, and he suddenly checked his unnatural laugh, to enable him to stare aghast upon his tormentors; a picture was exhibited of mental anguish and frantic rage, or mortified vanity and affected contempt which would almost deter an author from the pen, unless he could be sure of his firmness under every possible provocation. ${ }^{35}$

Sir Fretful was also a popular part of Charles Mathews's. ${ }^{36}$ Walter Scott describes the acting of Sir Fretful Plagiary by Mathews. On January 9, I 826, the novelist wrote: 'Mathews last night gave us a very perfect imitation of old Cumberland, who carried the poetic jealousy and irritability further than any man I ever saw. ${ }^{37}$ But Scott says also: 'It is not from a caricature that a just picture can be drawn, and in the little pettish sub-acidity of temper which Cumberland sometimes exhibited, there was more of humourous sadness than of ill-

${ }^{35}$ Boaden, Memoirs of the Life of John Philip Kemble, 36. (Melly describes Parsons as Sir Fretful. See Reminiscences, 237.

${ }^{36}$ Leigh Hunt regarded Mathews's Sir Fretful as perfect. The actor was painted in the rôle by DeWilde.

${ }^{37}$ The Journal of Walter Scott, 1.79. 
will. ${ }^{38}$ Cumberland does not mention Sir Fretful Plagiary in the Memoirs, and we can only imagine the pain it gave his sensitive nature.

Cumberland, on his side, seems to have felt a respect for Sheridan not discernible in his attitude towards Goldsmith or his other contemporaries. 'I could,' he says, 'name one living, who has made such happy use of his screen in a comedy of the first merit, that if Aristotle himself had written a whole chapter professedly against screens, and Jerry Collier had edited it with notes and illustrations, I would not have placed Lady Teazle out of ear-shot to have saved their ears from the pillory.'

Neither failure nor caricature could stop the steady flow of Cumberland's dramatic productions. He was, perhaps, alarmed by his sudden descent into mediocrity; and he seemed determined, at any price, to sustain his prestige. Plays and operas sped as swiftly from his pen as arrows from an archer's bow; the stage lay cluttered with his shafts, but the target, success, remained unscathed. The year of The Battle of Hastings saw two other productions come to light. There are rumours of private theatricals in the fall at Mr. Hanbury's theatre at Kelmarsh in Northamptonshire. Here was acted a tragedy, The Princess of Parma, with Cumberland in the dramatis personae of his own play. In the same month, on October 19, I778, appeared at Drury Lane 'the production of a hasty hour,' The Election. Cumberland's adherence to the conventional forms of his beloved sentimental comedy is attested by an outline of this piece

38 The Novels of Swift, Bage and Cumberland, 'Prefatory Memoir to Cumberland.' Sichel in his Life of Sheridan thinks Sir Fretful an exact portrait of Cumberland. He notes the erasure in the first draft of the scene, showing that Cumberland was originally treated even more severely. 
printed in The Town and Country Magazine for October. 'John, an honest Baker . . . though strongly importuned by his wife to vote for Sir Courtley, perseveres in his resolution. Even the temptation of the marriage of his daughter with Sir Courtley's particular friend cannot make him swerve from his resolution.' The Election was acted but a few times, yet the many lyrics achieved some popularity, and were widely printed. 'Considered as a literary composition,' says Lloyd's Evening Post of October 2 I, 'this interlude is the most execrable we ever met with.' But the reviewer adds: 'As all Election matter depends rather on being well timed than well written, we doubt not it will be a favourite with the audience when it is more perfect in the performance, as it really has a very good stage effect.'

On March 20, I779, at Covent Garden Theatre was acted the first of the three efforts of the year. Like Atalanta, Cumberland could not pursue his race steadily to its conclusion, but must stop for the golden apples. $\mathrm{He}$ had not yet learned the lesson that he was not equipped by nature to write opera. Calypso, as Cumberland named the new piece, was a sentimental masque, telling with a great show of insipid morality the story of Telemachus's resistance of Calypso. The masque was performed only three times, and would hardly have survived so long had it not been for some effective eighteenth century stage craft. The Public Advertiser of March 22 describes this at length. In conclusion the paper says: 'Upon the Sinking of Calypso and her Island, a very brilliant scene arises from the sea representing the Temple of Proteus, who, under the influence of Minerva, espouses the principal nymph Antiope, whose Character is rescued from the general Depravity of her Associates.' 
Cumberland's temporary desertion of his mistress 'legitimate comedy' was disastrous. The critics relentlessly condemned the masque, and, in particular, resented the author's dedication to the Duchess of Manchester, ${ }^{39}$ and 'a prelude in which he treated the printers of newspapers as a set of infamous fellows. ${ }^{40}$ Within the week the entire army of reviewers was upon Cumberland. George Cumberland wrote his brother: 'Mr. Cumberland's Comedy or Masque of Calypso was pretty well received on Saturday. I could not go to support it, being quite tired that day with hurry-however to-day the scribblers are at him in swarms-they have settled on it like a legion of Ants-every criticism different-and all the Same-viz. abusive.' ${ }^{41}$

'What may have induced Mr. Cumberland,' says The Westminster Magazine for March, 'to quit his April Muse (who certainly loved him) for other and more ungrateful Mistresses, perhaps the secret history of our theatric Powers can also inform us. In his Comedies, Mr. Cumberland is a chaste, elegant, and affecting Writer. In his tragedy, he is forced and flowery. In his Masque, he is often puerile.'

In the autumn of I 779 Cumberland brought out, within five weeks of each other, two adaptations of Elizabethan plays. The first of these (the year's second play) was

39 'If,' says Cumberland in his Dedication, 'when I am in search of the most virtuous character of the age, I should hesitate to resort to the Duchess of Manchester, I must be guilty of a very obstinate singularity.' The awkward superlative was taken by the critics to be an insult to the lady. The London Review for March says: 'That her Grace may be as virtuous as any woman in the realm is readily admitted; but a well-bred man, no loyalist or courtier, would not have paid a compliment to one woman at the expence of her whole sex.'

40 The Town and Country Magazine, March, 1779.

41 Cumberland Letters, 227. 
The Bondman, acted at Covent Garden on October I3. This piece was an adaptation of Philip Massinger's tragicomedy, The Bondman, first produced in 1638 at the Cockpit in Drury Lane by the Queen's Servants, and revived under Betterton's direction in I719. Cumberland's alterations consisted in deleting obsolete passages, and, in general, preparing it, as a critic remarked, "for the refined taste of modern times. ${ }^{42}$ Since no printed copy of Cumberland's play exists, the exact nature of the alterations cannot be known, but Genest affirms that they dealt in the main with the comic scenes.

Whatever the changes, the modern version of the Elizabethan play was moderately successful, although The Town and Country Magazine for October, disagreeing with The Universal Magazine, thought the piece 'strongly tinged with the improprieties of character and dialogue that prevailed at the time of its being written.' Yet 'there are,' the critic thinks, 'many judicious observations upon life and manners, which afford some scenic situations that produce a very happy effect.'

The second adaptation and the dramatist's third production of the year was The Duke of Milan, performed at Covent Garden on November Io.

Although this adaptation was more ambitious than that of The Bondman, being based upon Massinger's Duke of Milan, ${ }^{43}$ and Fenton's Marianne, ${ }^{44}$ it was acted only three times, and experienced as harsh treatment from the critics as had the earlier play. 'Last Night,' says The Dublin Advertiser on the morning after the play, 'was presented at the Theatre Royal in Covent Garden, a

42 The Universal Magazine, October, 1774.

43 Philip Massinger's Duke of Milan was acted at Blackfriars in 1638.

44 Marianne by Elijah Fenton was performed at Lincoln's Inn Fields on April 13, 1733. 
Tragedy taken from Massinger and Fenton, called the Duke of Milan, which is a very dull Alteration of Fenton's Marianne, and neither excited Applause nor Disapprobation, but was received with a Degree of Languor which marked the Indifference of the Audience as to the Fate of the Piece. . . .'

The newspapers of the day express their surprise at Cumberland's zeal in altering Elizabethan plays: ' $\mathrm{Mr}$. Cumberland's success was so great,' says The Westminster Magazine for November, 'as a Writer of sentimental Comedies, that we cannot help wondering at his deserting a path to Fame which he trod with ease and security, for another, with which he seems to be totally unacquainted.' Cumberland is advised to reserve himself for good comedy. 'He certainly will not,' the critic concludes with just conviction, 'add to his reputation, either by writing or compiling tragedies.'

Once more the author of The Brothers and of The West Indian endeavoured to re-establish his sinking fortunes. This time he essayed nothing less than a classical opera. The Widow of Delphi or The Descent of the Deities appeared at Covent Garden Theatre on February I, I 780 .

'This drama,' says Cumberland, 'will be considered as one of my most classical and creditable productions.' From the surviving fragments of The Widow of Delphi emerges a weak structure. The piece was apparently an opera based upon the model of Grecian comedy. It displays throughout a vast deal of scholarly lore.

Commenting upon the author's fear that the opera might miscarry for want of understanding upon the part of the audience, Lloyd's Evening Post of February 2 says: 'The fact is, it was too well understood, and the only 
difficulty we are under, is to pronounce which part of the house it was, that appeared most sensible of the defects with which it abounds.' The author of this review, after christening the opera 'a dramatic hodge-podge,' hazards a shrewd guess as to Cumberland's motives in writing so strange a drama. 'Indeed,' he says, 'if the author himself could have had any view in making it up, it must have been merely to let the world know that he is prodigiously read in ancient mythology, or that there are some men in the world who can induce the manager of a theatre to obtrude any kind of nonsense on the public, however egregious, and that at a very considerable expense to themselves, for to do justice to the manager's credulity, the piece was richly dressed, the scenery grand, and the characters as strongly cast as the company would admit.'

Cumberland's humiliations delighted at least one of his enemies. An animosity which had only lacked a definite target found it in the series of ill-fated plays. After remarking upon the death of Home's Alfred, Horace Walpole had prophesied a similar end for The Battle of Hastings, 'the child of as feeble a parent'; later he censures Calypso, 'a prodigy of dulness,' for its erotic lines.

But the satirist's anger rose to fever heat at another mention of Gray by Cumberland. This time the hapless dramatist had spoken of a scholarly work by Gray upon Philodamus $^{45}$ as 'a laboured and elegant commentary.' After tearing up all Cumberland's ideas and rhetoric upon the subject, Walpole twists the phrase over bitterly in his mind,- the pedantic and Bentleian epithets of laboured and elegant, terms far below any thing of

45 Bentley's Philodamus was acted at Covent Garden Theatre on December 14, 1782.

46 Correspondence of Horace Walpole and William Mason, Mitford ed., 11.117. 
Gray's writing, and only worthy of prefaces written by witlings, who are jealous of, and yet compliment one another; but laboured I dare swear it was not,' cries Walpole angrily, ' and for the wit of it, though probably true, Cumberland of all men living, is the worst judge, who told me it was pity Gray's letters were printed as they had disgraced him. I should be glad to see,' is Walpole's peroration, 'what this Jackadandy calls a commentary, and which I suppose was a familiar letter, and perhaps a short one, for Gray could express in ten lines, what the fry of Scholiasts would make twenty times as long as the text.' Walpole next attacks Cumberland's honesty in the use of his grandfather's notes. He ends with a thrust at Cumberland's opera.

'Mr. Cumberland,' he says, 'has written a laboured and elegant drama, which by the title I concluded was to be very comical, and more likely to endanger the celebrity of Aristophanes, than of any living wight: it is called The Widow of Delphi, or the Descent of the Deities, and I am told is to demolish the reputation of Caractacus. A précis of the subject was published two days ago in the Public Advertiser for the benefit of the illiterati, who are informed that poor Shakespeare was mistaken in calling the spot of the scene Delphos, instead of Delphi. I hope there will be a dance of Cyclopses (I don't know whether commentators will allow that termination) hammering, by the order of Venus, armour to keep the author invulnerable, who has hitherto been terribly bruised in all his combats with mortals. $\mathrm{He}$ is as sore as a tetter, yet always blundering into new scrapes. ${ }^{147}$

Such was the dramatic career of Cumberland between the time of the production of The Fashionable Lover in

${ }^{47}$ Letters of Horace Walpole, Toynbee ed., 11.117-8. 
I 772 and 1780 , a record of disappointments and failures, yet a record also of perseverance and hope, and as such not to be utterly condemned. In I 780 the world had taken leave of its greatest actor, David Garrick. Cumberland was not among the least bereaved; in spite of the dictator's occasional disregard of him, Cumberland mourned the loss of a friend. A letter written by him to Garrick, on the latter's retirement from the stage, is suggestive: 'The moment . . .' writes Cumberland, 'which puts my sincerity beyond the reach of misconstruction conveys to you the grateful acknowledgments of a man, who fairly owes to your judgment a share of the little fame he has gathered from the drama, and to your friendship many kind and obliging offices, which subsequent misunderstandings cannot obliterate. ${ }^{148}$

In general, the nature of the friendship between Cumberland and Garrick is clear. It was, in the main, onesided. While Cumberland's intense admiration for Garrick is almost always visible, it is equally evident that Garrick's feeling for Cumberland was a friendliness broken by occasional periods of hearty contempt. 'His plays,' the actor burst out to Northcote, 'would never do if I did not cook them up and make epilogues and prologues too for him. ${ }^{49}$ At another time he wrote Colman: 'It was impossible for you to satisfy Cumberland, had ye rack forc'd from you as much falsehood, as he had vanity-I am very glad you have prepar'd him for me; had you been as mischevious as you were sincere with him, you might have sent him so high season'd \& stuff'd so full $w^{\text {th }}$ conceit, that I should have had much ado to

48 Private Correspondence of David Garrick, 2.126-7.

49 Hazlitt, Conversations of James Northcote, 275. 
lower him . . . ${ }^{50}$ It is, nevertheless, within the bounds of belief, that much of this sprang from the petulance of Garrick. It is certain that he sought Cumberland's society, that he was with him at Foote's, at Romney's, and in Queen-Anne Street. 'Garrick,' says Cumberland of the actor's power over the small Cumberlands, 'could charm a circle of them about him whilst he acted the turkey-cocks, and peacocks and water-wagtails to their infinite and undescribable amusement.'

At Garrick's funeral, which Walpole declared had more than double the number of coaches at Lord Chatham's, Cumberland paid his last tribute among the group of 'intimate friends, occupying the twenty-sixth coach in the procession. ${ }^{51} \mathrm{He}$ has left a picture of that occasion which appeals deeply to the imagination. 'I saw,' he says, 'old Samuel Johnson standing beside his grave, at the foot of Shakespeare's monument, and bathed in tears.'

50 Posthumous Letters to Francis Colman, and George Colman, the Elder, 302.

51 The Gentleman's Magazine, October, 1780. 


\section{CHAPTER IX \\ JOHNSON AND HIS CIRCLE}

CUMBERLAND, 'the gentleman dramatist,' had social demesnes unknown to Hugh Kelly, or to Thomas Holcroft. During the first few years after The West Indian, he was 'running through his popularity,' as he himself described it, and was living with the great; he dined with them, and listened to tongues of flame hardly less nimble than those of The Mermaid Tavern. He had not access everywhere; his envious detraction had few admirers. But a benevolent turn of mind and learned conversation, spiced with many an anecdote, as well as unexceptionable birth and breeding, gained him entrance into most places of importance. He might have been found at the coffee-houses of note or at Mrs. Thrale's. The house in Queen-Anne Street welcomed many distinguished visitors to have tea with 'Cumbey.' Cumberland had strong powers for observing externals, and he has left several cameo-like portraits of the great Londoners of his time.

His picture of Soame Jenyns, ${ }^{1}$ whom Boswell credits with 'lively talents,' follows: 'He was the man,' Cumberland says with admiration, 'who bore his part in all societies with the most even temper and undisturbed hilarity of all the good companions, whom I ever knew. He came into your house at the very moment you had put

${ }^{1}$ In 1725 was published anonymously his poem, The Art of Dancing, and in 1757 appeared his Free Inquiry into the Nature and Origin of Evil. 
upon your card; he dressed himself to do your party honour in all the colours of the jay. . . . His eyes were protruded like the eyes of the lobster, who wears them at the end of his feelers, and yet there was room between one of these and his nose for another wen that added nothing to his beauty; yet I heard this good man very innocently remark, when Gibbon published his history, that he wondered any body so ugly could write a book.'

Cumberland, a judge of conversation as of acting, found that Soame Jenyns 'told you no long stories, engrossed not much of your attention, and was not angry with those that did; his thoughts were original, and were apt to have a very whimsical affinity to the paradox in them; he wrote verses upon dancing, and prose upon the origin of evil, yet he was a very indifferent metaphysician and a worse dancer; ill nature and personality, with the single exception of his lines upon Johnson, I never heard fall from his lips.'

It is inconceivable that so sensitive a mind as Cumberland's would not be stirred by the greatest one of the age. He has told us in the Memoirs of Samuel Johnson with affection and reverence. 'Mr. Cumberland assures me,' says Boswell, 'that he was always treated with great courtesy by Dr. Johnson.' 3 Samuel Johnson is linked in a far less definite way than Garrick to Cumberland. Bound by no professional ties of the drama, the relations of the two were social. They met in Mrs. Thrale's drawing-room, at Cumberland's home in Queen-Anne Street, and at the various taverns, notably Mrs. Ander-

2 This epitaph was printed in the magazines shortly after Johnson's death. The offensive lines were:

Boswell and Thrale, retailers of his wit,

Will tell you how he wrote, and talk'd, and cough'd, and spit.

${ }^{3}$ Boswell, Life of Johnson, Hill ed., 4.444, foot-note 1. 
son's British Coffee-House. On these fields Cumberland heard the artillery of the great logician, and his series of impressions form a remarkable picture of Johnson some ten years before his death. Cumberland saw him ready for society in the "brown coat with metal buttons, black waistcoat and worsted stockings,' and the 'flowing bob wig,' letting 'his next neighbor squeeze the china oranges into his wine glass after dinner.' 'It was never my chance,' Cumberland adds, 'to see him in those moments of moroseness and ill-humour, which are imputed to him,' but rather when he 'lent himself to every invitation with cordiality, and brought good humour with him, that gave life to the circle he was in.'

Another glimpse of Johnson is at Cumberland's own tea-table. 'I remember,' wrote the host, 'when Sir Joshua Reynolds at my house reminded him that he had drunk eleven cups, he replied-"Sir, I shall have released the lady from any further trouble, if it had not been for your remark; but you have reminded me that I want one of a dozen, and I must request Mrs. Cumberland to round up my number."

Cumberland relates several anecdotes of Johnson, one of which is included in The Observer, a periodical later published by Cumberland. Here Doctor Johnson is described as one who 'spoke with great energy, and in the most chosen language; nobody yet attempted to interrupt him, and his words rolled not with the shallow impetuosity of a torrent, but deeply and fluently, like the copious current of the Nile: He took up the topic of religion in his course, and, though palsy shook his head, he looked so terrible in Christian armour, and dealt his stroke with so much force and judgment, that Infidelity in the persons of several petty skirmishers, sneaked 
away from him, and kept baying at him whilst he was speaking, perpetually crying out-"Give me leave to observe-not to interrupt you, Sir . . ." The philosopher looked about for the insect that annoyed him, and having at last eyed him, as it were askaunce, demanded what it was provoked him to impatience"Have I said anything, good Sir, that you do not comprehend?" "No, no," replied he, "I perfectly well comprehend every word you have been saying." - "Do you so, Sir," said the philosopher, "then I heartily ask pardon of the company for misemploying their time so egregiously," and stalked away without waiting for an answer.'

The Observer itself Johnson might have directly influenced, for Cumberland consulted him in making his collections for the Greek dramatists, but the philosopher admitted that his studies had not lain in that direction. 'When Mr. Cumberland,' says Boswell, 'talked to him of the Greek fragments which are so well illustrated in The Observer, and of the Greek dramatists in general, he candidly acknowledged his insufficiency in that brand of Greek literature.' Cumberland's verses in Retrospection are à propos:

Johnson, if right I judge, in classic lore,

Was more diffuse than deep, he did not dig

So many fathoms down as Bently dug

In Grecian soil, but far enough to find

Truth ever at the bottom of the shaft. . . .

In the midst of all Cumberland's comment one thought stands out, a ray of insight: 'Who will say,' he asks, 'that Johnson himself would have been such a champion

4 The Observer, No. 17.

5 Boswell, Life of Johnson, Hill ed., 4.444. 
in literature, such a front-rank soldier in the fields of fame, if he had not been pressed into the service, and driven on to glory with the bayonet of sharp necessity pointed at his back?'

Northcote says that Johnson and his friends 'never admitted C_— as one of the set, ${ }^{\prime}$ and Cumberland was never elected to The Literary Club. We may believe that Cumberland's talents shone more brightly in smaller groups, and that it was after an evening at Mrs. Thrale's that Johnson paid Cumberland his remarkable tribute. 'The want of company,' he said, 'is an inconvenience: but Mr. Cumberland is a million.' Johnson also passed judgment upon Cumberland's odes. It was during an evening at the Crown and Anchor that Sir Joshua Reynolds mentioned them. "WWhy, Sir," said Johnson, "they would have been thought as good as Odes commonly are, if Cumberland had not put his name to them; but a name immediately draws censure, unless it be a name that bears down everything before it. Nay, Cumberland has made his Odes subsidiary to the fame of another man. They might have run well enough by themselves; but he has not only loaded them with a name, but he has made them carry double." 's

It is, at all events, certain that Cumberland was often in the circle at Streatham of which Johnson was the centre. Johnson writes Mrs. Thrale: 'This day I thought myself sure of a letter, but so I am constantly served. Mr. Cumberland . . . and Mrs. Byron, and anybody else, puts me out of your head; and I know no more of you than if you were on the other side of the

6 Hazlitt, Conversations of James Northcote, 275.

${ }^{7}$ Letters of Doctor Samuel Johnson, Hill ed., 2.111.

8 For Walpole's comment upon Cumberland's odes see pages 114 and 134. 
Caspian.' ${ }^{\prime}$ There is also a letter from Johnson to Mrs. Thrale seeming to deplore the failure of The Walloons, ${ }^{10}$ one of Cumberland's hastily written dramatic pieces. Boswell, strangely enough, followed suit in his liking for Cumberland. He admired The Fashionable Lover, ${ }^{11}$ and he speaks of Cumberland's 'keen, yet just and delicate pen. ${ }^{12}$ Cumberland, on his side, professed to read the Life of Johnson once a year. By a study of his life with Johnson's friends, Cumberland's foibles, particularly his jealousy, are brought into broad daylight. 'What,' was Johnson's puzzled question, 'makes $\mathrm{C} \longrightarrow$ hate $\mathrm{B} \longrightarrow$ ? ${ }^{13}$ $\mathrm{D} \longrightarrow,{ }^{14}$ he adds, 'is indeed a rival, and can upon occasion provoke a bugle. But what has $\mathrm{B}$ - done? Does he not like her book ?'15

The most ardent defender of Cumberland could find nothing that Fanny Burney had done, except the writing of an unacted play. ${ }^{16}$ She drew from Cumberland his jealousy in all its warmth, and whether by deliberation, or in sheer unconsciousness, he made her life steadily unpleasant whenever he was near. It was during an evening with Mrs. Thrale that Doctor Johnson heard the Cumberland family discussed. 'Mrs. Thrale said that $\mathrm{Mr}$. Cumberland was a very amiable man in his own house; but as a father mighty simple. . . . ${ }^{17}$ This

${ }^{9}$ Letters of Doctor Samuel Johnson, Hill ed., 2.117.

10 Ibid., 2.252.

11 Life of Johnson, Hill ed., 5.200.

12 Ibid., 4.75.

13 Fanny Burney.

${ }^{14}$ John Delap, poet and the author of numerous unsuccessful plays.

15 Letters of Doctor Samuel Johnson, Hill ed., 2.112.

${ }^{16} \mathrm{Mrs}$. Thrale had begged Miss Burney to write a comedy, and Sheridan had promised to accept anything of hers unseen. She wrote The Willings, but suppressed it.

${ }^{17}$ Diary and Letters of Madame D'Arblay, Dobson ed., 1.69-70. 
accounted, Mrs. Thrale thought, for the rude conduct of his daughters, and she told Miss Burney that 'about two years ago, they were actually hissed out of the playhouse, on account of the extreme height of their feathers! Dr. Johnson instantly composed an extempore dialogue between himself and Mr. Cumberland upon this subject, in which he was to act the part of a provoking condoler.' While Cumberland, by his discourtesy to Miss Burney, had offended Mrs. Thrale, Murphy ${ }^{18}$ was well established in her good graces. 'She told me, therefore,' says Miss Burney, 'in a merry way, that though she wished me to excel Cumberland, and all other dramatic writers, yet she would not wish me better than her old friend Murphy.' ${ }^{19}$ Miss Burney heard one more unpleasant echo of the dramatist before her meeting with him. She tells the story of his name being discussed at Mrs. Cholmondeley's. ${ }^{20}$ There was a talk of the marriage of the Duke of Dorset and Miss Cumberland, ${ }^{21}$ and the conversation naturally fell upon $\mathrm{Mr}$. Cumberland who was 'finely cut up.' 22

'What a man is that!' said Mrs. Cholmondeley: 'I cannot bear him-so querulous, so dissatisfied, so determined to like nobody and nothing but himself!'

'What, Mr. Cumberland?' I exclaimed.

'Yes,' answered she; 'I hope you don't like him?'

18 Author of the Gray's Inn Journal, and the plays, The Upholsterer, All in the Wrong, Know Your Own Mind, and Three Weeks after Marriage. Murphy was Cumberland's ardent enemy. See Murphy, Life of David Garrick, 86-91, 108-9.

19 Ibid., 1.91.

20 Mary Cholmondeley, sister of 'Peg' Woffington, the actress.

21 John Frederick Sackville, third Duke of Dorset. He married in 1745 Arabella, daughter of Sir Charles Cope, of Brewerne, Oxfordshire.

22 Diary and Letters of Madame D'Arblay, Dobson ed., 187-8. 
'I don't know him, ma'am. I have only seen him once, at Mrs. Ord's.'

'Oh, don't like him for your life! I charge you not! I hope you did not like his looks?'

'Why,' quoth I, laughing, 'I went prepared and determined to like him; but, perhaps when I see him next, I may go prepared for the contrary. ${ }^{23}$

From this time Miss Burney endured the ill will of the entire Cumberland family. The daughters surveyed her constantly with.curious eyes. ${ }^{24}$ Mrs. Cumberland looked at her 'as at a person she had no reason or business to know, ${ }^{25}$ while Cumberland himself zealously avoided the authoress.

23 Diary and Letters of Madame D'Arblay, Dobson ed., 187-8.

24 Miss Burney had seen Elizabeth and Sophia Cumberland and 'one of her sons' 'a handsome soft-looking youth' at Brighthelmstone in 1779. 'Mrs. Thrale,' she writes in her Diary, 'spoke to them, but I believe they did not recollect me. They are reckoned the flashers of the place, yet everybody laughs at them for their airs, affectations, and tonish graces and impertinences.' Later Miss Burney describes the girls at another gathering: 'There was a great deal of company, and among them the Cumberlands. The oldest of the girls . . . quite turned round her whole person every time we passed each other, to keep me in sight, and stare at me as long as possible; so did her brother. I never saw anything so ill-bred and impertinent; I protest I was ready to quit the rooms to avoid them; till at last Miss Thrale, catching Miss Cumberland's eye, gave her so full, determined, and downing a stare, that whether awed by shame or resentment, she forebore from that time to look at either of us. Miss Thrale, with a sort of good-natured dryness, said, "Whenever you are disturbed with any of these stares, apply to me,-I'll warrant I'll cure them. I daresay the girl hates me for it; but what shall I be the worse for that? I would have served Master Dickey so too, only I could not catch his eye." Diary and Letters of Madame D'Arblay, Dobson ed., $1.282,285,287-8$.

25 Ibid., 1.286. Evidence of the happiness of Cumberland's marriage venture may, perhaps, be had in Mrs. Cumberland's entire sympathy with his incivilities: 'By the way,' writes Miss Burney, 'Mrs. Cumberland has never once waited on Mrs. Thrale since our arrival, though till now, she always seemed proud enough of the acquaintance.' 
Miss Burney's sensibilities were as outraged as her own Evelina's, and her reflections upon Cumberland, as found in the Diary, are alive with natural, if feminine, resentment. That 'she can make use of pen and ink' she considers 'an insufficient cause for his illiberal . . . disposition,' and she quotes the opinions of her friends 'who impute the whole of this conduct to its having transpired that [she is] to bring out a play this season. ${ }^{26}$

Cumberland's uncontrollable weakness seems to have mastered him whenever he approached Miss Burney, and her judgment of him is even fairer than might be expected. 'Mr. Cumberland,' she declares, 'though in all other respects an agreeable and a good man, is so notorious for hating and envying and spiting all authors in the dramatic line, that he is hardly decent in his behavior towards them.' Doctor Johnson, Mrs. Cholmondeley, and the Thrales had all warned her against Cumberland's jealousy, Doctor Johnson telling her that he doubtless hated her, but Miss Burney had failed to take them seriously. Cumberland's envy of Miss Burney seemed to burn with an unholy light. "II would have sent for you," said Mrs. Thrale,' after a call from Cumberland, " "but 'hang it,' thought I, 'if I only name her, this man will snatch his hat and make off!'" ${ }_{27}$ 'Otherwise good, humane, and generous, ${ }^{\prime 28}$ as Miss Burney conceded, Cumberland's anxiety for his own fame left him peevish as a child.

At another time, Mrs. Thrale, who tortured Cumberland exquisitely with her raillery, suggested the expedient of having Doctor Delap and Miss Burney strut on either side of him, armed, respectively, with a dagger and a

26 Diary and Letters of Madame D'Arblay, Dobson ed., 1.286.

27 Ibid., 1.289.

28 Ibid., 1.290. 
mask to represent tragedy and comedy to the suffering Cumberland. Doctor Delap, in his turn, proposed that Miss Burney and he each burn a play apiece to placate the green-eyed monster.

Cumberland's rudeness and avoidance lasted throughout the winter of I779, and the success of Evelina seemed to throw him into a deep depression. This reacted curiously upon Miss Burney who writes with some touch of fear: 'I am concerned to have ever encountered this sore man, who, if already he thus burns with envy at the success of my book, will, should he find his narrowness of mind resented by me, or related by my friends, not only wish me ill, but do me every ill office hereafter in his power. Indeed, I am quite shocked to find how he avoids and determines to dislike me . . . I shall still, however, hope, if I can but keep Mrs. Thrale's indignant friendship within bounds, to somewhat conciliate matters, and prevent any open enmity, which authorizes all ill deeds, from taking place. ${ }^{29}$

Of the many anecdotes concerning Cumberland and Fanny Burney a story connected with Evelina most deserves a full narration. The authoress herself tells the story. Having observed Miss Burney with Mrs. Thrale, Cumberland said to the latter:

'Oh, that young lady is an author, I hear!'

'Yes,' answered Mrs. Thrale, 'author of Evelina!'

'Humph,-I am told it has some humour!'

'Ay, indeed! Johnson says nothing like it has appeared for years!'

'So,' cried he, biting his lips, and waving uneasily in his chair, 'so, so!'

${ }^{29}$ Diary and Letters of Madame D'Arblay, Dobson ed., 1.292. 
'Yes,' continued she, 'and Sir Joshua Reynolds told Mr. Thrale he would give fifty pounds to know the author!'

'So, so-oh, vastly well!' cried he, putting his hand on his forehead.

'Nay,' added she, 'Burke himself sat up all night to finish it!'

This seemed quite too much for him; he put both his hands to his face, and moving backwards and forwards, said,

'Oh, vastly well! - this will do for anything!' with a tone as much as to say, Pray no more! Then Mrs. Thrale bid him good-night, longing, she said to call Miss Thrale first, and say, 'So you won't speak to my daughter?-why she is no author!'30 'For my part,' said Mrs. Thrale another time, 'I'd have a starling taught to halloo Evelina!'31

There are few bonds between Cumberland and the other members of Johnson's circle. With Bennet Langton or with Beauclerc he had no intercourse, if, indeed, he knew them. Cumberland had opportunities to meet Sir Joshua Reynolds not only at the British Coffee-House, but also, in all probability, at his own home in Queen-Anne Street. $^{32}$ Reynolds is mentioned infrequently in the Memoirs. He is contrasted to Johnson and Soame Jenyns in conversation, ${ }^{33}$ is named as one of the claquers at She Stoops to Conquer, ${ }^{3+}$ and is paid a tribute by Cumberland in execrable verse:

Late, very late on this sequester'd isle,

The heav'n descended art was seen to smile;

${ }^{30}$ Diary and Letters of Madame D'Arblay, Dobson ed., 1.291-2. Dobson says that these passages descriptive of Cumberland read like a scene in The Critic. Dobson, Life of Fanny Burney, 106.

31 Diary and Letters of Madame D'Arblay, Dobson ed., 1.298.

32 Memoirs, 1.357.

33 Ibid., 1.335-6.

${ }^{34}$ Ibid., 1.367. 
Seldom she came to this storm-beaten coast, And short her stay, just seen, admir'd and lost. Reynolds at length, her favorite suitor, bore The blushing stranger to his native shore. ${ }^{35}$

But Cumberland's partiality for Romney made him less appreciative of Reynolds. In a letter dated August I4, I774, describing some pictures at the annual exhibition, he writes: 'Our friend Sir Joshua, though very voluminous, had nothing supremely capital, coarse and flaring in his style and colours, he seems tired with nature and is bringing in vagaries to hide his want of improvement. ${ }^{36}$

Moreover, Northcote tells of Cumberland's dislike for Reynolds. One day Garrick said: "He hates you, Sir Joshua, because you do not admire his Correggio." "What Correggio?" answered Sir Joshua. "Why, his Correggio," replied Garrick, "is Romney, the painter." ',

Cumberland has also celebrated Edmund Burke in verse. Cumberland's admiration for him was strong, and in curious juggling lines he has contrasted his mental powers with those of Johnson.

Both had a taste

For contradiction, but in mode unlike;

Johnson at once would doggedly pronounce

Opinions false, and after prove them such:

Burke, not less critical, but more polite

With ceaseless volubility of tongue

Play'd round and round his subject, till at length,

Content to find you willing to admire,

He ceas'd to urge or win you to assent. ${ }^{38}$

35 Memoirs, 2.216-7.

36 Chamberlain, George Romney, 72.

37 Ibid., 248. 


\section{Cumberland says that}

The pen which Burke encourag'd, Johnson spurn'd ;38

and that

Burke, by his senatorial power obtained, Ten times as much as Johnson by his pen.

In style,
Burke display'd
A copious period, that with curious skill
And ornamental epithet drawn out,
Was, like the singer's cadence, sometimes apt,
Although melodious, to fatigue the ear. . . . ${ }^{38}$

Cumberland's pleasure in the pamphlet on the French Revolution led him to write Burke a letter of thanks which brought the following amenity: 'You may be assured, that nothing could be more flattering to me than the approbation of a gentleman so distinguished in literature as you are, and in so great a variety of its branches. ${ }^{30}$

38 Retrospection. See Mudford, Life of Richard Cumberland, 247-9.

39 Ibid., 2.271-3. 


\section{CHAPTER X}

\section{AMBASSADORSHIP TO SPAIN}

I $N$ the year I 780 Cumberland's dramatic and social 1 careers were interrupted. $\mathrm{He}$ suddenly believed that he saw the way clear to political preferment. The Spanish fleet shattered by Rodney, 'the greatest of all seamen save Nelson and Drake,' had slunk away to Cadiz, but Spain and France still plotted, and Cumberland believed he had discovered important business of the secret agents of these countries. 'Of these communications,' he says mysteriously, 'I made that use, which my duty dictated, and to my judgment seemed advisable.' The circumstances of his appointment as ambassador are unknown; he was soon embarked upon the most unfortunate venture of his life, which had for its immediate end 'a secret negociation with the Minister Florida Blanca' of Spain.

On April 28, I780, with his wife and two daughters, Elizabeth and Sophia, Cumberland set sail on His Majesty's frigate, Milford, for Lisbon. He was accompanied by the Abbé Hussey, 'Chaplain to his Catholic Majesty.' After a storm which tested the leaky frigate, a French man-of-war appeared. An engagement followed in which the Frenchman suffered heavy losses in killed and wounded, and was finally captured. 'When I

1 A disproportionate space in the Memoirs is taken up by what The Edinburgh Review for April, 1806, calls a 'long and languishing account' of the trip to Spain. 
witnessed,' says Cumberland, 'the dispatch, with which a ship is cleared for action, the silence and the good order so strictly observed, and the commands so distinctly given upon going into action, I was impressed with the greatest respect for the discipline and precision observed on board our ships of war.' One sailor 'had his arm shattered by the first fire of the enemy, which he received with the most stoical indifference, and would not be persuaded to leave the quarter-deck till the action was over, when going down to be dressed as my eldest daughter (now Lady Edward Bentinck) was coming up from below, he gallantly presented that very arm to assist her, and when, observing him shrink upon her touching it, she said to him- "Serjeant, I am afraid you are wounded-" he calmly replied- "To be sure I am, Madam, else I should not have been so bold to have crossed you on the stairs.", Cumberland wrote a sea-song in celebration of the victory. 'We frequently,' he says, 'sung it at Lisbon in lusty chorus, but [the sailors'] delicacy would not allow them to let it be once heard till their prisoners were removed.' On May 17 the Milford anchored at Lisbon.

The plan was that Hussey should proceed to Aranjuez, and sound the mind of the Spanish government in respect to certain negotiations with England. In the event of an unfavourable reply, Cumberland was to return home immediately, otherwise he was to pursue his journey into Spain, ostensibly en route for Italy. One strict order bound Cumberland, as representative of the English government. No parlance was to be admitted involving the cession of Gibraltar.

A reading of Hussey's note from Aranjuez left Cumberland at a puzzling cross-roads: 'I arrived here three 
days ago,' he wrote, 'conversed with the minister of state upon the subject of your journey, and do find that the delays, which this business met with, and the different turn, which matters have taken, render this negociation every day exceedingly arduous and difficult. However as the minister is so very desirous of finding some means to bring it to a happy conclusion, and as you are already so far advanced on your journey, I think it by all means advisable that you come . . . and so give the negociation a fair trial.'

Of Gibraltar, the token for advance or retreat, Hussey had said not a word! Cumberland had now the unpleasant task of balancing his chances for success against the humiliation of an immediate return to England. An advance meant unquestioning reliance upon a loyalty and sagacity not over-clear in the Abbé Hussey's ambiguous note, and something very like disgrace if this reliance were ill-founded. A retreat, on the other hand, meant dull failure. The timid, ambitious Cumberland wrote the Earl of Hillsborough, then Secretary of State, two letters. In the first he outlined the situation, and gave his decision to proceed. The second, written the next day, began: 'I am sensible I have taken a step, which exposes me to censure upon failure or success, unless the reasons, on which I have acted, shall be weighed with candour and even with indulgence. In the decision, I have taken for entering Spain, I have had no other object but to keep alive a negociation, to which any backwardness or evasion on my part in the present crisis would I am persuaded be immediate extinction. I know where my danger lies, but as my endeavours for the public service and the honour of your administration are sincere, I have no doubt but I shall obtain your protection.' 
Such a letter indicates that Cumberland took a deep personal responsibility in his decision to go to Madrid. It is fairly evident that his ambition overcame his judgment, and that he played recklessly for a high stake. In judging the treatment Cumberland received from the government at the end of his mission, it should be remembered that, at the outset, he had little guarantee of success, and that it was largely a personal venture. In addition, Cumberland had been warned against the journey by the English minister at Lisbon. His own uncertainty of mind is shown by a letter written to Hussey while en route: 'I have entered on an arduous service without any conditions, and I fear without securing to myself that sure support, which they, by whom and for whom I am employed, ought to hold forth to me. . . .' 'If,' he adds, with some acumen, as later events proved, 'success does not bear me through in this step, which I have taken, my good intentions will not stand me in much stead.'

Cumberland had left Lisbon on June 8, i780. After a ten days' journey, which reads like a romance, with tales of inns and Castilian highwaymen, he joined Hussey at Aranjuez, and on the next day met the Count Florida Blanca.

All things, Cumberland thought, seemed favourable: 'Spain had received a recent check from Admiral Rodney, Gibraltar had been relieved with a high hand, she was also upon very delicate and dubious terms with France. The crisis was decidedly in my favour; my reception flattering in the extreme; the Spanish nation was anxious for peace, and both court, ecclesiastics and military professedly anti-gallican.' Yet at this propitious time the ambassador was undone by the unluckiest of 
accidents. With spirits somewhat dashed by stories of the Gordon riots, yet hopeful, Cumberland came to his interview with the Count Florida Blanca: 'I had prepared myself to the best of my capacity for a meeting and discussion, which it behoved me to manage with discretion and address, and which according to my view of it promised to crown my mission with success. We were to unite, and Campo was to be present, so that when I entered the minister's inner chamber, and saw only a small table with a single candle, no Campo present and no materials for writing, I own my mind misgave me: I did not wait more than two minutes before Florida Blanca came out of his closet, and in a lamentable tone sung out the downfall of London; king, ministers and government whelmed in ruin, the rebellion of America transplanted to England, and heartily as he condoled with me, how could he under such circumstances commit his court to treat with me?'

The mischief was wrought. No word from Cumberland could allay the apprehensions of the Spanish court, nor was the situation altered when definite news arrived that the Gordon riots were finally quelled. Spanish confidence was gone, and the rest of Cumberland's efforts were piecework. He persisted in efforts to bring about a negotiation in which the forbidden word, Gibraltar, had no part, but what was foremost in Spanish minds easily found an outlet in their speech. As Cumberland said: 'they wanted only to talk about Gibraltar, and I was not permitted to hear it named.'

2 'It is reported,' says The Gentleman's Magazine for June, 1782, 'that [Mr. Cumberland's] embassy would have been successful, but for the capture of the East and West India fleets which inspired the Spaniards with more confidence than they had before possessed.' 
The story of Cumberland's life in the Madrid of 1780 has interest. In August of this year, Richard Denison Cumberland, ${ }^{3}$ cousin to our dramatist, wrote his brother George: 'I was told to-day $\mathrm{Mr}$. Cumberland has been taken great notice of abroad-pray tell me what you have heard of his Business there-wish he had taken you for he is good in a public Capacity, 'tis a good Road to Preferment.'*

Cumberland had received flattering evidences of esteem. The King gave him, for his royal master in England, two of his finest horses, and celebrated with him the birthday of George the Third. 'I have hinted at the surprise,' says Cumberland, 'which my friend Count Kaunitz expressed upon the present of the royal horses, it was again his chance to experience something of a like nature, when he did me the honour to dine with me upon the $4^{\text {th }}$ of June, when with a few cordial friends I was celebrating my beloved sovereign's birth-day in the best manner my obscurity and humble means allowed of. On this occasion I confess my surprise was as great as his, when the music of every regiment in garrison at Madrid, not excepting the Spanish guards, filed into my court-yard, and afforded me the exquisite delight of hearing those, who were in arms against my country, unite in celebrating the return of that day, which gave its monarch birth.'

Cumberland passed his many leisure hours among the paintings in the palace, or with a group of friends, all

${ }^{3}$ There survives a letter from Cumberland, written from Queen-Anne Street on February 16 [1772?] to his cousin, Mr. Richard [D.?] Cumberland of Magdalene College, Cambridge. The letter offers encouragement and advice on the young man's entering upon his university career. The British Museum, Add. MS. 36491 f. 12.

* Cumberland Letters, 267. 
of the Spanish aristocracy. Among these he names the Count Pallavicini, the Nuncio Colonna, at that time cardinal elect, and others of distinction. In walking through the Escurial on one occasion, Cumberland surprised the King in his bed-chamber. 'The good man,' says Cumberland, 'had been on his knees before his private altar, and upon the opening of the door, rose; when seeing me in the act of retiring, he bade me stay, and condescended to show me some very curious South American deer, extremely small and elegantly formed, which he kept under a netting; and amongst others a little green monkey, the most diminutive and most beautiful of its species I had ever seen.' The monarch was 'humbly lodged,' having but 'a small camp bed, miserably equipped with curtains of faded old damask, that had once been crimson,' but beside it was the Mater Dolorosa of Titian. ${ }^{5}$

Madrid boasted but a single theatre, 'small, dark, illfurnished, and ill-attended.' Yet from this unworthy home of the drama, Cumberland carried away an enriching experience. 'When,' he says, 'the celebrated tragic actress, known by the title of the Tiranna played, it was a treat, which I should suppose no other stage then in Europe could compare with. That extraordinary woman, whose real name I do not remember, and whose real origin cannot be traced, . . . was not less formed to strike beholders with the beauty and commanding majesty of her person, than to astonish all that heard her by the powers, that nature and art had combined to give her.' A friend having told the actress that Cumberland

${ }^{5}$ In the Escurial Cumberland examined 'a curious manuscript, purporting to be letters of Brutus. . . . These letters are written in Greek, and are referred to by Doctor Bentley in his controversy with Boyle as notoriously spurious, fabricated by the sophists, of which there can be no doubt.' See Nichols, Literary Anecdotes of the Eighteenth Century, 2.168. 
was a writer for the stage, it was agreed that he should attend the theatre only when she sent for him, that he might see her at the height of her art. Cumberland's account of her acting and his meeting with her follows: 'I had not then enough of the language to understand much more than the incidents and actions of the play, which was of the deepest cast of tragedy, for in the course of the plot she murdered her infant children, and exhibited them dead on the stage lying on each side of her, whilst she, sitting on the bare floor between them (her attitude, action, features, tones, defying all description) presented such a high-wrought picture of hysteric phrensy, laughing wild amidst severest woe, as placed her in my judgment at the very summit of her art; in fact I have no conception that the powers of acting can be carried higher, and such was the effect upon the audience, that whilst the spectators in the pit, having caught a kind of sympathetic phrensy from the scene, were rising up in a tumultuous manner, the word was given out by authority for letting fall the curtain, and a catastrophe, probably too strong for exhibition, was not allowed to be completed.

'A few minutes had passed, when this wonderful creature, led in by Pietra Santa, ${ }^{b}$ entered my box; the artificial paleness of her cheeks, her eyes, which she had dyed of a bright vermilion round the edges of the lids, her fine arms bare to the shoulders, the wild magnificence of her attire, and the profusion of her dishevelled locks, glossy black as the plumage of the raven, gave her the appearance of something so more than human, such a Sybil; such an imaginary being, so awful, so impressive,

6 'Count Pietra Santa, lieutenant of the Italian band of bodyguards was my most dear and intimate friend.' Memoirs, 2.103. 
that my blood chilled as she approached me not to ask but to claim my applause, demanding of me if I had ever seen any actress, that could be compared with her in my own, or any other, country.'

Cumberland's family found much favour in the capital. His wife and daughters were entertained by the Princess of Asturias, and the young ladies who so dismayed Fanny Burney $^{7}$ wakened Madrid. 'When,' says Cumberland with pride, 'these young Englishwomen, habited in their Spanish dresses, (and attractive, as I may presume to say they were by the bloom and beauty of their persons) passed the streets of Madrid, their coach was brought to frequent stops, and hardly found its passage through the crowd.' Count Kaunitz, ${ }^{8}$ the imperial ambassador, wooed without success Elizabeth Cumberland, dying soon after her departure from Spain. The Count Pallavicini paid his attentions, in turn, to both the daughters.

In the meantime, the negotiations for a separate treaty dragged, and then stopped. The French ambassador, Count D'Estaing, blocked Cumberland successfully and repeatedly, and Hussey's selfishness and effrontery became so intolerable that Cumberland was glad to see him off, at last, for England. A letter from Lord Hillsborough written on December 9, I 780, showed that there was little hope at the English court of the accomplishment of Cumberland's purpose. One sentence was significant: 'I do not, . . ' wrote the Secretary of State, 'as yet signify to you the king's command for your return, though I see little utility in your remaining at Madrid.' Cumberland was now prepared for a recall; the futility of his mission was daily becoming more apparent, Florida

7 See Diary and Letters of Madame D'Arblay, 1.286-8.

8 Count Kaunitz was one of the four sons of the famous Austrian statesman, Wenzel Anton Kaunitz-Rierburg. 
Blanca talking of nothing save Gibraltar. Soon afterwards, the sword fell, and Cumberland's Spanish mission was added to the list of fruitless and forgotten political ventures.

After a farewell to his friends Cumberland began the return. Two Spanish coaches carried his family, now including the infant daughter, Frances Marianne, and a troop of servants and outriders accompanied him. At a place on the journey between Valladolid and Burgos Cumberland offered his snuff box 'to a grave elderly man, who seemed of the better sort of Castilians, and who appeared to have thrown himself in [his] way. . . .' The stranger taking Cumberland's snuff, looked earnestly at him, and said: "I am not afraid, sir, of trusting myself to you, whom I know to be an Englishman, and a person, in whose honour I may perfectly repose. But there is death concealed in many a man's snuff box, and I would seriously advise you on no account to take a single pinch from the box of any stranger, who may offer it to you." , This conversation recurred to Cumberland, when, a few days later, he was seized with terrible pains in his head. On the seventeenth day he reached Bayonne, where he sank down in a delirious fever which granted him a merciful oblivion of his utter financial ruin. Unwearying care saved his life, but he arrived in England disappointed, broken in health, and virtually a bankrupt. 'Mr. Cumberland,' says The Gentleman's Magazine for July, I $78 \mathrm{r}$, 'who lately arrived from Spain, was at Court, and was closeted a considerable time with his Majesty.' A long account of financial relations between Cumberland and the government in respect to the Spanish mission is given in the Memoirs. It is, however, enough tó say 
that Cumberland was refused any reimbursement for expenditures hardly to be endured by any private fortune. ${ }^{9}$ Cumberland says: 'I solemnly aver that I had the positive pledge of the Treasury through Mr. Robinson for replacing every draft I should make upon my banker.' 'I wearied the door of Lord North,' he says, 'till his very servants drove me from it.' A long memorial, detailing his sufferings and the promises of the government, availed him nothing. The government evidently considered that Cumberland's mission was undertaken, in all respects, at his own risk, and that, in denying him remuneration for fourteen costly months in Spain, they followed the letter, if not the spirit, of justice. It is unlikely that Cumberland received any stipend, since he states flatly in the Memoirs that he did not, and since he died poor. On the other hand, it has been noted that letters exist proving that he received from the Crown a patent making him a Provost Marshal, and Mudford ${ }^{10}$ speaks of the air of mystery which pervades his narrative. The conclusion can only be that, while the exact facts are unknown, Cumberland received no adequate reward for the sacrifice of his fortune.

Walpole has two characteristic comments upon the expedition. In August of 1780 he writes Mason that other events are 'a little obscured already by the entire capture of our East and West Indian Fleets by the Spanish squadron, under the nose of the sentimental Dr. Cumberland. I suppose he will be recalled now like the illustrious Storemont and Eden as he has executed his

${ }^{9}$ Cumberland affirms that the King of Spain, through Florida Blanca, offered to reimburse him for his expenses, but that he refused.

10 See Mudford, Life of Richard Cumberland, 352-89, for his account of the journey to Spain. 
Mission; for we contrive to send Proxies to receive affronts. ${ }^{\prime 11}$

A few months after Cumberland's return Walpole writes with, it must be confessed, a rather keen sense of the ridiculous side of Cumberland's mission: 'I should as soon admire Mr. Cumberland's successful negotiations in Spain, where he stayed begging peace till Gibraltar was battered to the ground. I hope he will write an ode himself on the treaty he did not make, and like Pindar fill it with the genealogy of the mule on which he ambled from the Prado to the Escurial, and when I am a mule I will read it.'12

${ }^{11}$ Letters of Horace Walpole, Toynbee ed, 11.261-2.

12 Ibid., 12.13-4. In the British Museum may be found The Diplomatic Papers of Richard Cumberland, mostly concerning the negotiations with Spain, 1780, 1781, including an autograph draft of a memorial of Cumberland to Lord North, for payment for his services. Add. MS. 28851. This book was read by the King, also by Lord Walsingham, when nominated as ambassador to Spain. 


\section{CHAPTER XI}

\section{AT TUNBRIDGE WELLS AS MAN OF LETTERS. -THE WALLOONS.-THE MYSTERIOUS HUSBAND}

THE Spanish fiasco would seem enough, but ill for1 tune had not done with Cumberland. At the end of Lord North's administration he was dismissed from his position as secretary of the Board of Trade and given a compensation. 'By the operation of this reform,' says Cumberland, 'after I had sacrificed the patrimony I was born to, a very considerable reduction was made even of the remnant, that was left me.' Necessity demanded economy, and in $178 \mathrm{I}$ Cumberland moved his family to Tunbridge Wells. The house at Tunbridge was destined to be a hive of literary industry for thirty years. During this time were written plays, averaging one a year, and three long novels, besides numerous essays and fragments of verse. Either from a desire to forget a bitter experience of public life, or from sheer busyness, Cumberland at once devoted himself wholly to reading and writing. His eminence as a dramatic writer and his great conversational powers had earlier gained him entrance into literary circles; his name seemed linked with nearly every great one of the century. A slight figure in Johnson's circle, he became a powerful one in later years because he was its only survivor. Between $178 \mathrm{I}$ and $\mathrm{I} 800$ he saw the last of Johnson, Reynolds, Gibbon, Boswell, Burke, and Walpole; so that by the beginning of the 
century he had attained the outlook of the man who has outlived his generation.

Cumberland's social life during the first score of years of his living at Tunbridge is closely bound up in his dramatic friends. He is on good terms with Holcroft; Michael Kelly and Bannister run down to Tunbridge Wells; and there is many a literary dinner at Dilly's. At Tunbridge Wells is his real domain. Here is his library, the grist for innumerable plays and books, here his garden, and here are his dependants who regarded him with genuine reverence. For broken health, and for a spirit depressed by misfortunes, Tunbridge Wells must have seemed a welcome refuge.

A result of the leisure hours in Madrid appeared in I 782, in two volumes of Anecdotes of eminent Painters in Spain. 'Mr. Cumberland,' says The Gentleman's Magazine for April, I782, 'in his late excursion to the continent succeeded much better as a cognoscenti than a politician,' and adds that 'on the whole Mr. Cumberland's "Anecdotes" both in matter and manner, are a very proper appendage to Mr. Walpole's." Although this book is a fairly trustworthy history of the Spanish school of painting, and comprises, in addition, a catalogue of the paintings in the royal palace at Madrid, Cumberland's belief 'in its future was ill founded: 'If,' he says, 'it were not a ridiculous thing for an author to give his own works a good word, I should be tempted to risque it in the instance of these two volumes of anecdotes; forasmuch as I bear them in grateful remembrance, as having cheered some of my heaviest hours, and as being the first

${ }^{1}$ Walpole's Anecdotes of Painting in England appeared from 1762 to 1771. 
productions sent by me into the world after my return out of Spain.'

Walpole's jealousy bubbled over again: 'Cumberland's book,' he wrote Mason, 'is called Anecdotes of Spanish Painters. To show he has been in Spain (of which he boasts though with little reason) he spells every name (that is not Spanish) as they do; the Fleming Rubens he calls (to Englishmen) Pedro Pablo Rubens and Vitruvius Viturbio. Two pages are singularly delectable; one of them was luckily criticized this morning in the Public Advertiser, and saves me the trouble of transcribing. Speaking of Subjection of Spain to the Carthaginians, he says "When Carthage was her mistress it is not easy to conceive a situation more degrading for a noble people than to bear the yoke of mercantile republicans, and do homage at the shop-boards of upstart demagogues;" would not one think,' continues Walpole, and his irritable wit was never more pointless, 'it was a Vere or a Percy that wrote this impertinent condolence, and not a little commis-[Cumberland] goes on- "Surely it is in human nature to prefer the tyranny of the most absolute despot that ever wore a crown to the mercenary and imposing insults of a trader. Who would not rather appeal to a court than a compting house," most worthy ejaculation. This in a free commercial country, and from a petty scribe in office!

Walpole had not forgotten Cumberland during the residence in Spain; he eagerly scanned the dramatic reviews for his enemy's unfortunate plays. To the satirist Cumberland had become a kind of nether touchstone for comedy. The Anecdotes he considered merely 'cox-

2 Letters of Horace Walpole, Toynbee ed., 12.233-4. The Anecdotes was unfortunate in many ways; Sir Joshua Reynolds was offended by a slighting reference. 
combical,' but he assailed the plays mercilessly. When in 178 I Clergyman Pratt offered to the unappreciative world his tragedy of The Fair Circassian, Walpole exclaimed sympathetically; 'Bad enough to be Cumberland's!'s

The dramatist was, indeed, writing with suicidal zeal. The pilgrimage to Spain had failed to dampen his ardour for play-writing; while there he had apparently collected material for a new comedy, which was finished and christened The Walloons before he settled at Tunbridge Wells. The play was acted at Covent Garden Theatre on April 20, I782. A hint of the character of its reception may be had in a letter from Doctor Johnson. He wrote Mrs. Thrale that Cumberland had made $£_{5}$ by the play and 'lost his plume.' The Walloons was evidently a product of the months in Spain. The plot is intricate and thin.

Father Sullivan and Lady Dangle buy silence of each other, he wishing concealment of his political schemes, and she Sir Solomon Dangle's ignorance that her first husband lives. This comedy has the old figures of the missing character, the adventuress, the henpecked husband, and the stage villain, while a coterie consisting of Pat Corey, Tipple, and Kitty lend a dubious vein of humour to the piece. The arrival of Lady Dangle's first husband effects a dénouement which involves the imprisoning of Lady Dangle in a convent, the release of Sir Solomon, and the arrest of Father Sullivan.

In reviewing the play, The Westminster Magazine for April asserts that 'Mr. Cumberland's late residence in Spain was expected to produce more advantage to the

3 Letters of Horace Walpole, Toynbee ed., 12.258.

4 Letters of Doctor Samuel Johnson, Hill ed., 2.252. 
dramatic, than to the political world,' and regrets that Cumberland's unavoidable acquaintance with Lopez de la Vega, 'the father . . . of pantomimical plays' should have 'diverted the simple and elegant pathos, by which he acquired so much deserved reputation in The West Indian, to tread the thorny and intricate mazes of modern farces, called comedies, in which he will never succeed.'

In spite of this supposed lapse of Cumberland from the higher moral tone, the critic pays him the tribute of thinking that the play "has a kind of merit which no dramatic writer has laid claim to in the last ten or fifteen years, except the author himself, in The West Indian; and Mr. Colman in "The Suicide" ity!' 'Two or three of the characters of this play,' the reviewer observes, 'are marked with new and genuine colours. All our writers of late have served up "hachées," very decently cooked, and very tolerably seasoned; but an Englishman wishes now and then to sit down to a fresh joint of meat. The present is a little "smutted" in taking up, but it will be better than any "hachée.",

Out of this intricate comedy, having 'a redundance of business which, indeed, would have sufficed for two or three plays in the hands of some dramatist, ${ }^{6}$ emerges the character of Father Sullivan, the conspirer for the Walloons. Henderson, the actor, was responsible for the creation of this forceful stage figure. He suggested to Cumberland that he construct a character "in the cast of Congreve's "Double Dealer." "Make me," he said, "a fine bold-faced villain, the direst and the deepest in

5 Colman's play, The Suicide, was acted with little success at Drury Lane Theatre on July 11, 1778.

- Biographia Dramatica, 4.389 . 
nature I care not, so you do but give me motives, strong enough to bear me out, and such a prominency of natural character, as shall secure me from contempt of my audience; whatever other passions I can inspire them with will never sink me in their esteem." ${ }_{r}$ Beneath his fearful stage-dye Father Sullivan's malevolence is convincing. Henderson was excellent in the part, and during The Walloons' short run of six or eight nights, ${ }^{8}$ he exhibited a most inimitable specimen of his powers in Father Sullivan.

Perhaps Cumberland found a solace for this and other failures in the quiet of Tunbridge Wells. One reason for his selection of the village as a place of abode was its proximity to Stonelands. Here lived, during part of the year, Lord George Germain, Viscount Sackville. An hour's ride brought Cumberland to his patron and friend. Wraxall describes Sackville's patronage of authors, following the custom of his house, and observes that many of Cumberland's plays were written at Stonelands or at Drayton, Wraxall himself having several times assisted at the reading of tragedies or comedies. Sackville describes in a letter to Wraxall the composition of The Mysterious Husband, a play soon to appear, and expresses his forebodings as to the outcome. 'Cumberland,' he says, "is writing a new sort of tragedy in familiar dialogue, instead of blank verse; for which I conclude he will be abused till he has a severe fit of bile.' There follows a hint of Cumberland with his admirers: 'Four acts are finished. The ladies have attended the reading of them,

7 Cumberland denied that Father Sullivan was an adumbration of the Abbé Hussey.

${ }^{8}$ Genest, 6.227. Genest gives six performances to The Walloons, but The Theatrical Register of The Gentleman's Magazine credits the play with eight. 
and say they are very moving. . . . I declined the pleasure,' says Sackville, 'because I fear I never can commend any performance equal to the expectation of the author.'

At times, however, Sackville lent a hand in the revisions, and even dared to criticize the plays of his friend. He writes Wraxall: 'Cumberland . . . has finished a new comedy; and I have seen it, and the dialogue is remarkably well. There was something in the characters, in the moral part of them, that I disliked and I was in doubt whether I might venture to declare it. But, as I cannot forbear speaking truth, out it came; and instead of being offended, he adopted the idea; and it is all to be altered according to my plan. Was I not a bold man to attack an author?'10 This comedy, which Sackville watched develop, was The Natural Son. The character of Dumps, which he disliked, was finally removed from the cast.

Cumberland has commemorated his friendship for Sackville in various ways. He published in The Gentleman's Magazine, in I 782, a poem, On the Marriage of Miss Sackville to Mr. Herbert, awkward verses in honour of his patron's daughter, Eliza. He also celebrated his friend in The Observer. The Diary of a Lady-In-Waiting, a quaint memoir of the time, describes the charm of this essay, with its account of Cumberland's visit to Sackville's home after his death. 'What hours of placid delight,' says the Observer, 'have I passed within these walls! Have I ever heard a word here fall from his lips, that I have wished him to recall? . . .'11

Cumberland pictures Sackville at the close of his life,

9 Wraxall, Posthumous Memoirs, 1.423-4.

10 Ibid., 1.423-4.

11 The Observer, No. 48. 
an aged soldier riding slowly about his estate, followed by his groom, and giving sixpences to the children of the poor who opened the gates for him. At church, Cumberland says, "he had a way of standing up in sermon-time for the purpose of reviewing the congregation, and awing the idlers into decorum, that never failed to remind me of Sir Roger de Coverley . . . but when,' says Cumberland, 'to the total overthrow of all gravity, in his zeal to encourage the efforts of a very young declaimer in the pulpit, I heard him cry out to the Reverend Mr. Henry Eatoff in the middle of his sermon-"Well done, Harry!" it was irresistible.' At another time 'when his ear . . . had been tortured by a tone most glaringly discordant, he set his mark upon the culprit by calling out to him by name, and loudly saying, "Out of tune, Tom Baker-!"'

An account of Sackville by Cumberland, entitled the Character of the late Lord Viscount Sackville, a pamphlet published shortly after Sackville's death, led The Gentleman's Magazine for January, I 786, to say: 'His surviving friend Cumberland has here, with great precision, delineated the features of [Lord Sackville's] mind, and is highly commendable for giving his testimony in favour of one whom he "not without reason, thought well," but "whom too many conspired to traduce." 'I have,' said a correspondent in the March issue of the same year, "too much regard to truth, and love of justice, not to agree with Mr. Cumberland, that Lord George Germain was an injured man.' For Cumberland himself disbelieved fully in the story of Sackville at Minden. ${ }^{12}$ 'He would says he, 'talk plainly, temperately and briefly to me, as

12 Lord Sackville was accused of cowardice at the battle of Minden, in 1759 , and was dismissed from the service. 
his manner was, provided I would promise him to deal sincerely, and not spare to press him on such points, as stuck with me for want of explanation. . . . When I compare what he said to me in his last moments (not two hours before he expired) with what he stated at this conference, if I did not from my heart, and upon the most entire conviction of my reason and understanding, solemnly acquit that injured man, (now gone to his account) of the opprobrious and false imputations, deposed against him at his trial, I must be either brutally ignorant, or wilfully obstinate against the truth.'

Almost the last words of Sackville were addressed to Cumberland: "You see me now in those moments," he said on his deathbed, "when no disguise will serve, and when the spirit of a man must be proved. I have a mind perfectly resigned, and at peace within itself. I have done with this world, and what I have done in it, I have done for the best; I hope and trust I am prepared for the next. Tell not me of all that passes in health and pride of heart; these are the moments, in which a man must be searched, and remember that I die, as you see me, with a tranquil conscience and content_-" '13

Cumberland's memorial to his friend was discussed in an interview which Fanny Burney had with His Majesty in 1785 : 'The King,' runs the Diary, 'said he had just been looking over a new pamphlet, of Mr. Cumberland's, upon the character of Lord Sackville.

" "I have been asking Sir George Baker," said he, "if he had read it, and he told me yes; but that he could not find out why Cumberland had written it. However, that,

${ }^{13}$ See The Memoirs of Stockdale, 1.429: 'I hope', says the author of this work, 'that lord SACKviLLE's old confidential friend; [sic] the learned, and ingenious Mr. Cumberland, is still living, and well. He can never forget the last scene of his patron's mortal state.' 
I think, I found out in the second page. For there he takes an opportunity to give a high character of himself."

'He then enlarged more upon the subject, very frankly declaring in what points he differed from Mr. Cumberland about Lord Sackville; but,' concludes Miss Burney, 'as I neither knew him, nor had read the pamphlet, I could not at all enter into the subject. ${ }^{14}$

The Mysterious Husband, which Sackville had watched take form, appeared at Covent Garden on January 28, I783.

The tragedy, which is in prose, deals with the unpleasant theme, not unfamiliar in literature, of the secret marriages of a father and son to the same woman. The action of the tragedy rises to a climax by a series of discoveries. Lady Davenant, living wholly estranged from her husband, learns that Marianne, the sister of Dormer, her lover, is privately married to the younger Davenant; Marianne finds, in turn, that a former husband is not dead as supposed, but alive in London; and Lady Davenant's terrible discovery is that Lord Davenant is this husband. Release for all comes in the death of Lord Davenant by suicide.

The Mysterious Husband was Cumberland's first trial of the popular field of domestic tragedy. The plot of the play was suggested by Walpole's Mysterious Mother ${ }^{15}$ which deals with similar events veiled in the decent obscurity of an earlier age. Notwithstanding the intrusion of such a subject upon a moral theatregoing public, and notwithstanding the faults of a play which caused Walpole to growl that it was no more in prose than any of Cumberland's plays, ${ }^{16}$ the tragedy was

14 Diary and Letters of Madame D'Arblay, Dobson ed., 2.341.

15 Horace Walpole's Mysterious Mother appeared in 1768.

${ }^{16}$ Letters of Horace $W$ alpole, Toynbee ed., 12.395. 
moderately successful, and again brought hope to the author's friends.

Cumberland's belief in the drama as an instrument of moral reform was growing with the years. The February number of The Town and Country Magazine acknowledges the 'several affecting situations, in which the dialogue is animated and characteristic,' but observes especially that aspect of the play so completely hidden from the modern reader: 'Mr. Cumberland's design in this tragedy is certainly to lash, expose, and punish, with poetic justice, fashionable vice.' Likewise The Universal Magazine of this month says: 'Being written in a stile of elegant and pathetic prose, it seems to have that great end in contemplation, of attacking by melancholy consequences the fatal effects of fashionable vice. ${ }^{\prime 17}$

The interest of the play centered largely in Lord and Lady Davenant. Lord Davenant seems to us a very uncertain, mawkish villain, but The British Magazine declares that 'the variety of passions exhibited by Lord Davenant, as they alternately spring from the effect of his treachery, his tyranny, his remorse, and the struggles of native honour, compound a character of the strongest and most tragic complexion.' Cumberland succeeds in enveloping the leading characters of The Mysterious Husband in a strange sentimental gloom, and something of this was felt by the critics of the time. 'Lord Davenant,' says the reviewer, 'is highly wrought, but the tints are too uniformly dark and gloomy. The scene of his exit, in the fifth act, is shocking, and rather terrifies than affects.' ${ }^{18}$ 'Lady Davenant,' says Cumberland, '. . . I

17 Genest, 7.265.

18 The British Magazine, February, 1783. 
am inclined to consider as the best female part I have ever tendered to the stage.' The sentimental interest in virtue in uneasy station might well have been inspired by Lady Davenant. 'The conduct of Lady Davenant,' says The British Magazine, 'towards her lord, her lover Dormer, her rival Marianne, Charles Davenant, Sir Henry Harlowe, and Sir Edmund Travers, rises by a progression of novel and affecting incidents, to a perfection of character beyond which convention never carried any fabulous heroine, and gives employment to many very affecting scenes and situations. ${ }^{19}$ 'The epilogue,' says The Universal Magazine, 'was rather too satirical on our modern fair sex, in asserting that there was not such an amiable wife now to be found as Lady Davenant. We hope for the honour of the sex, that, even in this age of dissipation, there are many Lady Davenants to be found in this country. ${ }^{20}$ Lady Davenant has the indescribable, faint grace of personality which Cumberland attains in a few feminine characters, and she has, in addition, force, making her a vital figure in the drama.

While the excellence of a few characters makes The Mysterious Husband worth the reading today, it has also its place in dramatic history. The student of drama will find the play an outgrowth of the tendency to write plays of natural English life. The Mysterious Husband is akin to the plays of George Lillo, and has its lineage in those of Thomas Heywood. Professor Thorndyke considers it an excellent specimen of 'domestic tragedy.'

This play contained in its prologue two lines which Genest declares have reference to the ancient quarrel with Sheridan:

19 The British Magazine, February, 1783.

20 The Universal Magazine, February, 1783.

21 Tragedy, 319. 
Now parody has vented all its spite, Let tragedy resume her ancient right.

Whether or not Sir Fretful's hurt was yet healed, we cannot know, but there are rumours of the continued malice of Sheridan, though this is less active and less bitter. Richardson, the author of The Fugitive, tells a story that in its day had great vogue: 'Mr. Cumberland came one night to Mr. Sheridan's box in the theatre somewhat late, and stumbled at the entrance. Mr. Sheridan sprang forward and assisted him. "Ah! Sir," said Cumberland, "you are the only man to assist a falling author." Mr. Sheridan, in waggery or forgetfulness, said, "Rising, you mean," the very words which Mr. Sheridan has assigned to Sir Fretful Plagiary in "The Critic.", 22

Perhaps of all Cumberland's tormentors Horace Walpole relaxed least. He had had his sneer at The Mysterious Husband, and the years immediately following are filled with his derisive laughter. The dislike was cordial on both sides, and, in his perpetual irritation at the eccentric dramatist, Walpole seems to have had somewhat the worst of the affair. Nobody could accuse Cumberland of playing the hypocrite with those whom he disliked. He doubtless avoided Walpole as he did Fanny Burney. Either Walpole's friend, Cole, or himself, had suffered at the hands of Cumberland, for Walpole writes Cole: 'Mr. Cumberland's brusquerie. is not worth notice,

22 Cumberland was still famed as a plagiarist. A writer to The Gentleman's Magazine for July, 1783, in commenting upon the dulness of the news, suggests a number of 'secrets,' all to be delivered in 'whispers.' Among the bits of gossip occurs the following: 'I heard Mr. Cumberland whisper Mr. Andrews between you and I-there is a deal of damned stuff and plagiarism brought upon the stage.' See Taylor, Records of $M y$ Life, 2.163-4. 
nor did I remember it. ${ }^{23}$ The letters to the Countess of Ossory have a good share of Walpole's ridicule of Cumberland. The gift of a laurel crown from Lady Ossory again brought Cumberland to Walpole's mind. 'I give,' he writes, 'your ladyship a thousand thanks for the crown of laurel you sent me: I tried it on immediately; but it certainly was never made for me; it was a vast deal too big, and did not fit me at all. . . . I will not be such a bear as to send back your ladyship's favour; but if you would give me leave to present it to poor $\mathrm{Mr}$. Hayley, or Mr. Cumberland, who ruin themselves in new laurels every day, it would make them as happy as princes; and I dare answer that either of them would write an ode upon you, not quite so good perhaps, yet within a hundred thousand degrees as excellent as Major Scott's ${ }^{24}$ and at least better than Mr. Warton's. ${ }^{23,}{ }^{26}$

In ${ }_{78} 3$ Mason had attempted a literary coalition with Dr. Johnson, his object being the administration of the Blue Stocking Club without the direction of Mrs. Montagu. But he writes Walpole: 'Cumberland will not come into our plan unless I give him my word and honour that I will write prologues to all the plays he has now on the stocks, or shall have on the stocks. Hard terms as these are, I believe I shall have public spirit enough to accede to them. ${ }^{\prime 27}$ This last may be jest, but the incident shows that Cumberland's literary influence was not negligible.

Cumberland's attitude towards Walpole was one of consistent dislike, untempered, as far as we know, by

23 Letters of Horace Walpole, Toynbee ed., 12.269.

24 Major John Scott, agent for Warren Hastings. During the latter's trial he produced numerous useless letters, speeches, and pamphlets.

25 Joseph Warton published Odes in 1744 and 1746.

26 Letters of Horace $W$ alpole, Toynbee ed., 13.271.

27 Correspondence of Horace Walpole and the Reverend William Mason, Mitford ed., 2.332-3. 
flattery. He considered that his uncle Bentley's 'connexion with Mr. Horace Walpole, the late Lord Orford, had too much of the bitter of dependance in it to be gratifying to the taste of a man of his spirit and sensibility; the one,' he says, 'could not be abject, and the other, I suspect, was not by nature very liberal and large-minded.' Cumberland excuses Walpole's 'querulential' nature on the score of gout, but declares him an author 'who seemed to play at hide-and-seek with the public.'

Cumberland's social set included, of course, Mrs. Montagu. It is unlikely that the Blue Stockings would make the dramatist eternally of them. The Memoirs tells at length of a dinner at Mrs. Montagu's; there are, however, no other mentions of her. In an essay, later included in Cumberland's paper, The Observer, occurs his his opinion of Lady Mary. Here, under a thin veil of fictitious names, the writer satirizes well-known figures of the age. Vanessa can be no other than Mrs. Montagu. 'The celebrated Vanessa has been either a beauty or a wit all her life long; and of course has a better plea for vanity than falls to most women's share. . . . Vanessa in the centre of her own circle sits like the statue of the Athenian Minerva, incensed with the breath of philosophers, poets, painters, orators, and every votarist of art, science, or fine speaking. It is in her academy, young noviciates try their wit and practise panegyric; no one. like Vanessa can break in a young lady to the poetics, and teach her Pegasus to carry a side-saddle. ${ }^{28}$ It is not too much to believe that the socially ambitious Cumberland was jealous of Mrs. Montagu's following. The obvious ill temper of the passage angered Fanny Burney, who says in her Diary: 'How infinitely severe a criticism is

${ }^{28}$ The Observer, No. 17. 
this Vanessa upon Mrs. Montagu! Do you remember hearing Mr. Cambridge read it at Twickenham? I think it a very injurious attack in Mr. Cumberland; for whatever may be Mrs. Montagu's foibles, she is free, I believe, from all vice, and as a member of society is magnificently useful. This, and much more to the purpose, I instantly said to her Majesty, defending her, as well as I was able, from this illiberal assault. The Queen was very ready to hear me, and to concur in thinking such usage very cruel. ${ }^{29}$

So many are the petty quarrels in Cumberland's life that we turn again with relief to a friendship at once genuine and lasting. His devotion to George Romney had persisted, and had now developed into intimacy. It is certain that Cumberland was in the habit of naming subjects for the painter; these the latter accepted, and we find him listening to his friend's criticisms with respectful attention. Cumberland on one occasion saved Romney's life by prompt attention during a serious illness. Romney, on his part, relieved the dramatist's distressful condition, after his return from Spain, by a timely loan. There survive letters from Cumberland to Romney, written while the artist was in Italy, all of which manifest the warmest friendliness. As he had not hesitated to dispraise Mrs. Montagu and others in The Observer, he was not slow to eulogize his friend. Under Greek names he discusses the great painters. Reynolds is drawn as Parrhasius; West as Apelles; and Romney as Timanthes. 'This modest painter, though residing in the capital of Attica, lived in such retirement from society that even his person was scarce known to his competitors. Envy never drew a word from his lips to the disparagement of

${ }^{29}$ Diary and Letters of Madame D'Arblay, Dobson ed., 3.71-2. 
a contemporary, and emulation could hardly provoke his diffidence into a contest for fame which so many bolder rivals were prepared to dispute. ${ }^{, 30}$

Romney died in 1802 . The task of writing his life was Hayley's, but before this work appeared, Cumberland published in The European Magazine for June, I 803 , a short essay upon him. An insinuation against Hayley himself, in addition to certain temperate criticisms of Romney by Cumberland, provoked the biographer, and explain the many allusions to Cumberland in Hayley's Life of George Romney. ${ }^{31}$

The success of The Observer, and the fame of The Mysterious Husband and The Carmelite attest the wide scope of his literary activities, and his position as a man of letters.

30 The Observer, No. 99.

31 See Hayley, Life of George Romney, 8, Mudford, Life of Richard Cumberland, 462, and Chamberlain, George Romney. 


\section{CHAPTER XII}

\section{AT TUNBRIDGE WELLS (Continued).-THE CARMELITE.-THE OBSERVER}

THE success of The Mysterious Husband again led Cumberland into the paths of tragedy, paths always fraught with danger for the writer of sentimental comedy. On December 2, I784, The Carmelite was acted at Drury Lane Theatre. The plot deserves notice as typical of Cumberland's sentimental tragedy style.

St. Valori, disguised as a Carmelite, is wrecked upon a desolate coast, and finds his wife, Matilda, mourning him in loneliness and despair. He observes secretly her intimacy with Montgomeri, unaware that the youth is really their son. Hildebrand, who has been the Carmelite's comrade in many perils, but who does not know the latter's real name, is tortured by repentance for having long ago killed, as he thinks, St. Valori. $\mathrm{He}$ confesses to St. Valori and dies forgiven. In a 'shrine decorated with funeral trophies, ${ }^{1}$ St. Valori, removing his cowl, reveals himself to Matilda. Husband, wife, and son are reunited and we have 'a tragedy that terminates merrily.'2

The Carmelite enjoyed a success far disproportionate to its merit. This was attained in a large measure by skilful use of scenic devices. 'The managers,' says The Lady's Magazine, 'brought forth this Tragedy with

1 The Carmelite, 5.1.

${ }^{2}$ Doran, Annals of the Stage, 2.145 . 
great splendor. The scenes are admirably painted and do credit . . . to the actors particularly the illuminated scene of the Chapel.' To The English Review, also, The Carmelite 'seems much better calculated for theatrical representation than the closet. Stage effect appears everywhere to be studied with much care and considerable success. There are situations, of which it is impossible, that in the hands of a skilful performer, they should not command the loudest bursts of applause. The interest is regularly accumulated; and the dénouement is rapid, well prepared and natural. ${ }^{3}$

The London Magazine for December praises the possibilities for acting in The Carmelite: 'The situations are productive of the highest dramatic effect, and are beautiful throughout. Under this description may be considered the Carmelite's first interview with the lady; the revealing of Montgomery's birth; the discovery Hildebrand makes of his being the murderer of Lord St. Valori; the comfort Hildebrand receives, in finding St. Valori still lives; and many others equally productive of effect.'

Unusual praise for The Carmelite occurs in The London Chronicle of December 3: 'Few plays,' this paper says, 'were ever perhaps better received throughout, and scarcely any which ended amidst such thundering peals of applause.' Miss Seward, a regular theatre-goer of the time, writes: "Cumberland's "Carmelite," written for Mrs. Siddons, and supported by her through many nights with éclat, pleases me exceedingly. It is not without faults, but the beauties greatly overbalance."

3 The English Review, January, 1785. The resemblance of The Carmelite to Home's Douglas was widely observed.

4 Journals and Correspondence of Thomas Sedgewick Whalley, 1.418. 
On account of the prominence of Mrs. Siddons ${ }^{5}$ as Matilda, the characters of The Carmelite themselves receive little attention. The critic of The European Magazine for December condemns Hildebrand, played by Palmer, ${ }^{6}$ denouncing his 'remorses' as 'feeble and uncharacteristic.' His indecision and dawdling repentance mark him as the villain of sentimental comedy, and he differs from Penruddock, Lord Sensitive, and Belfield Senior only in his costume of the armoured knight.

The interest in The Carmelite lies, first and last, in the acting of Mrs. Siddons in the part of Matilda. On March 15, I785, the actress wrote Dr. and Mrs. Whalley: 'I am now going to act in "The Carmelite," a tragedy of Cumberland's." A simple prelude to an evening of triumph! 'The performance of Mrs. Siddons,' says The London Magazine, 'was above panegyric; the tears which fell at her call are the noblest tributes of praise.' In 'dress . . . well calculated to express dignity and sorrow,' 'the inimitable Siddons' ${ }^{\circ}$ ruled her audience. 'In many parts,' says The Lady's Magazine, 'of Mrs. Sid-

5 Mrs. Siddons was, at this time, at the very height of her career. 'She was probably,' says Joseph Knight, 'the greatest actress this country has known.' Cumberland admired Mrs. Siddons intensely. This play is dedicated to her, she is praised in The Observer [No. 17], and Rogers relates Cumberland's tribute to her. See The London Chronicle of October 11, 1782, for an account of her powers of acting, and, also, Campbell, Life of Mrs. Siddons, 1.290.

${ }^{6}$ John Palmer was one of the most popular and versatile actors of Drury Lane. Genest credits him with acting over three hundred parts.

7 Journals and Correspondence of Thomas Sedgewick Whalley, 1.430.

8 The London Magazine, December, 1784.

9 The phrase, 'the inimitable Siddons,' has been much quoted as Cumberland's. Cumberland actually says: 'She played inimitably, and in those days, when only men and women trode the stage, the public were contented with what was perfect in nature, and of course admired and applauded Mrs. Siddons.' See Memoirs, 2.219. For Cumberland's picture of her in society see The Observer, No. 17. 
dons' very powerful passion, the house was dissolved with her sorrows. ${ }^{10}$ By the very greatness of the actress it was felt that the value of the rôle was less dramatic than theatrical. So The Lady's Magazine says that: 'It seemed to be the prevalent idea, that the poet had too often sacrificed to the lady the probabilities which are essential to illusion. To exhibit the varieties of her talent, he has introduced too many fits of madness and fainting, and too much of the jeu de theatre which diffuses modern tragedy.'

The Carmelite is by far the best of Cumberland's tragedies in verse, yet, after all, it is a bad tragedy. No blindness can condone its tottering structure, its wooden plot, or doleful sentimentalism. Notwithstanding, it has stateliness of language, and, above all, a curious quality of cathedral-like dimness and gloom. The entire play is so overcast with strange monastic lights and shadows, that the effect is that of a weird Gothic drama. The Carmelite is the comedy of Cumberland in darkness, or sentimental drama in a minor key.

A scant three weeks later, on December 22, The Natural Son, a sentimental comedy by Cumberland, was acted at Drury Lane Theatre. The play tells in diverting fashion of the adventures of Blushenly, an attractive young renegade without name or fortune, and strongly reminiscent of Tom Jones. The Natural Son was much condemned by the critics for the slenderness of its plot, and it was ultimately compressed into four acts. 'It has of late,' says The Universal Magazine for December, 'been remarkably the lot of the theatres to produce plays which begin well, and sink both in interest and effect as they proceed. The Natural Son is a piece which comes

${ }^{10}$ The Lady's Magazine, December, 1784. 
within this description. The first and second acts are good ones, and though there are many happy incidents, excellent sentiments, and pointed witticisms and remarks in the third, fourth, and fifth, yet considered as acts, they are by no means equal to those that precede them. It were to be wished that Mr. Cumberland had compressed his plot, and written the comedy in three acts only; all would then have been alive and interesting.' The characters are not without interest, for among them rings again the jovial laughter of Major O'Flaherty. His genial wit, however, has suffered a change since we saw him last with Belcour, and the sympathetic reader notes that his fortunes have not risen. 'Major O'Flaherty,' says the reviewer of The Westminster Magazine, 'throws sad disgrace on young Dudley,' for the votaries of the earlier play knew the promise that 'Dudley made at the conclusion of the West Indian,' and now the Major is 'totally unprovided for.' ${ }^{11}$ Cumberland's reversion to novelists and to his own earlier plays indicates far from a wealth of invention.

Yet The Natural Son is one of the most entertaining of his comedies. The easy dialogue often rises into wit, and the 'just sentiment strongly expressed,' ${ }^{12}$ as Biographia Dramatica has it, is tinged with 'genuine humour.' Thus, while its rambling structure denied it success on the stage, its dialogue and its story, though 'not so finely and naturally blended as that of Fielding's wonderful Foundling, ${ }^{13}$ assure its power 'in the closet.' 'It is,'

11 The 'promise' made Major O'Flaherty occurs in the last act of The West Indian. Dudley to O'Flaherty: 'We have stood many a tough gale, and abundance of hard blows, but Charles shall lay us up in a little private, but safe, harbour, where we'll rest from our labours, and peacefully wind up the remainder of our days.'

12 Biographia Dramatica, 4.74.

13 The London Magazine, December, 1784. 
says Dunham, 'a miniature novel, its best scenes possessing the peculiar kind of interest which is independent of the aid of acting. ${ }^{14}$ Soon after was acted, on March 8, I 785, at Covent Garden, The Arab, with Henderson and Mrs. Pope. The play was not acted twice.

We have seen that after the return from Spain Cumberland's mode of life had greatly altered. At Tunbridge Wells there was no affluence; there was, however, ease and quiet, and in the calm of these years we seem to find again the student of the Cambridge days. But a mind so naturally creative as Cumberland's could not rest in literary inaction. In this time when poverty and disappointment must have been often in his thoughts, the deep seriousness of his nature is apparent. 'My mind,' he admits, 'had been harassed in a variety of ways, but, the spirit, that from resources within itself can find a never-failing fund of occupation, will not be easily broken by events, that do not touch the conscience.' Thus the ceaseless play-writing may be traced in some measure to weariness of spirit, and our wonder at Cumberland's promiscuous creation of poem, novel, and essay may soften into some pity for a disappointed man. We cannot regret the essays. Shortly after his establishment at Tunbridge Wells he had begun the series of papers which were to be known to the world as The Observer; these were an expression of long study and thought which could find an outlet through no other channel. 'I took,' he says, 'a larger and more various range of study than I had ever done before, and collaterally with other compositions began to collect materials for those essays, which I afterwards compleated and made public under the title of The Observer.' It was a fortunate experiment

${ }^{14}$ Eminent Literary and Scientific Men of Great Britain and Ireland, 3.361 . 
for Cumberland. The Observer is neglected; but those who like to reblaze old literary trails will find it interesting. The lover of old books will wish that Cumberland had written more essays.

Though published in large groups, in quarto form, The Observer was modelled upon the popular periodical essay of the early part of the century. Cumberland explains: 'My first wish was to have followed the steps of those essayists, who have so successfully set the fashion of publishing their lucubrations from day to day in separate papers. This mode of marching into the world by detachments has been happily taken up by men of great generalship in literature, of whom some are yet among us. ${ }^{15}$

The essays may be divided into three general classes. In the first division fall all papers pertaining to the observation of human life. Here are the diminuitive novels, such as the Story of Melissa ${ }^{18}$ or Nicolas Pedrosa, ${ }^{17}$ and here the essays with various comments on men and manners, such as the essay on Dampers, ${ }^{18}$ or the one on The Love of Praise. ${ }^{19}$ Forming a second group are the essays upon literary subjects, such as the Review of the Samson Agonistes, ${ }^{20}$ and, more particularly, the scholarly and learned essays concerning Greece and her literature. A third division may be made of the philosophical, moral, and religious essays. Examples of these are: Notion that Death may be Avoided at Will, ${ }^{21} \mathrm{On}_{n}$

15 The Observer, No. 1.

16 Ibid., No. 23.

${ }_{17}$ Ibid., Nos. 88, 89, 90. Cumberland denies that he took this essay from a Spanish source.

18 Ibid., No. 2.

19 Ibid., No. 3.

20 Ibid., No. 76.

21 Ibid., No. 59. 
Gaming, ${ }^{22}$ Defence of Christ's Miracles Against Modern Cavils. . . . ${ }^{23}$ The line of demarcation between these divisions is often indistinct. There is in all the papers a constant intrusion of Cumberland's knowledge of the ancients, and a deep undercurrent of moral sentiment. Thus the Dangers of Sudden Elevation ${ }^{24}$ are illustrated by the letters of Pisistratus, and the story of Leontine ends in a moral disquisition on duelling. ${ }^{25}$

The miscellaneous essays upon life make together onehalf the bulk of The Observer. These essays have mild interest today, but concern us primarily as they reveal Cumberland's personality. In the essay on Dampers are suggestions of the man. Here Cumberland unloads the irritation of his sensitive nature towards uncongenial spirits.

Dampers are to be known in society by a sudden damp, which they are sure to cast upon all companies, where they enter. Moreover, if one of the company risques a sally for the sake of goodfellowship, which is a little on the wrong side of truth, or not strictly reducible to proof, a Damper may with great propriety set him right in the matter of fact, and demonstrate, as clear as two and two make four, that what he has said may be mathematically confuted, and that the merry gentleman is mistaken. A Damper is to keep strict watch over the morals of the company, and not to suffer the least indiscretion to escape in the warmth of conviviality. . . . If any glance is made at private characters, however notorious, a Damper steps in with a recommendation of candour, and inveighs most pathetically against the sin of evil-speaking. He is never merry in company, except when any one in it is apparently out of spirits, and with such an one he is always exceedingly pleasant.

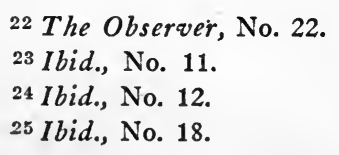


It is in discussing, with an angry comment from Pliny, the effect of Dampers on sensitive men that the real Cumberland, perhaps, speaks out: 'I think it is a remark with as few exceptions to it as most general remarks have, that brilliant talents are attended with extreme sensibility, and the effects of sensibility bear such resemblance to the effects of vanity, that the undiscerning multitude are too apt to confound them. These are the men, who, in their progress through life, are most frequently misunderstood, and generally less pitied than they ought to be. ${ }^{26}$ In another essay Cumberland discusses sensibility with insight: 'There is a certain delicacy in some men's nature, which though not absolutely to be termed a moral attribute, is nevertheless so grateful to society at large, and so recommendatory of those who possess it, that even the best and worthiest characters cannot be truly pleasing without it: I know not how to describe it better than by saying it consists of a happy discernment of "times and seasons." ${ }_{27}$

Besides references to Dampers, throughout The Observer, there are many paragraphs on envy, dissimulation, and jealousy. Cumberland's dispraise of Puffing culminates in an account of the practice in the theatres: 'I cannot dismiss the subject without hinting to the proprietors of our Royal Theatres, that this expedient of puffing is pardonable only in a troup of strollers, or the master of a puppet-shew. Whilst the muses keep possession of our theatres, and genius treads the stage, every friend to the national drama will condemn the practice, and hold them inexcusable, who are responsible for it, if they do not discontinue it. . . . I have no doubt but the

28 The Observer, No. 2.

27 Ibid., No. 55. 
good sense of the proprietors will determine on a reform; for I am persuaded they cannot be profited by houses of their own filling, nor any author flattered by applauses of his own bestowing. ${ }^{28}$ Similarly, he condemns Ventidius, 'the modestest of all men; he blushes when he sees himself applauded in the public papers; he has a better reason for blushing than the world is aware of; he knows himself to be the author of what he reads. ${ }^{29}$ In another number of The Observer is described at length a libeller's melancholy remorse, as displayed in a letter to the editor. This gentleman, whom Cumberland christens Walter Wormwood, pictures, after his failure as an author, his own gradual disintegration of character. 'Disgusted with the world, I now began to dip my pen in gall, and as soon as I had singled out a proper object for my spleen, I looked round him for his weak side, where I could place a blow to best effect, and wound him undiscovered: the author above mentioned had a full share of my attention; he was an irritable man, and I have seen him agonized with the pain, which my very shafts had given him.

Wormwood now tells of his shame in his base occupation: 'The solitude I resorted to, made me every day more morose, and supplied me with reflections that rendered me intolerable to myself, and unfit for society.' The libeller is at length exposed and thus laments his fate: 'Alas! can words express my feelings? Is there a being more wretched than myself? to be friendless, an exile from society, and at enmity with myself, is a situation deplorable in the extreme: let what I have now written be made public; if I could believe my shame could be turned to others' profit, it might perhaps become less

28 The Observer, No. 20.

29 Ibid., No. 30. 
painful to myself. ${ }^{30}$ Cumberland concludes the essay with his verses on Envy.

Such expressions from 'the man without a skin' prove only too conclusively how long the stings of the critics kept him uncomfortable. The ludicrous picture of Wormwood, the repentant critic, indicates Cumberland's moral and sentimental attitude towards his defamers, and also the lasting pain which he suffered at their hands.

Cumberland's attack upon critics in The Observer brought forth one of his best essays, namely, an imagined criticism of the first night of Othello. Although the idea is an absurd one, that adverse criticism is likely to be in proportion to a play's merit, and that the great writers of the past would suffer equally with the moderns from the malicious press, yet the essay itself is striking, and may be the first of its kind. ${ }^{31}$

Anything which Cumberland has to say in regard to the stage warrants consideration. In spite of her enmity toward him, Fanny Burney wished him to stage her play. ${ }^{32}$ Rogers speaks of him as a good judge of acting, ${ }^{33}$ and it was Cumberland who found Henderson, perhaps the second actor of the age. ${ }^{34}$

'There is ample evidence,' Boaden says, 'in his Observer, that Mr. Cumberland was one of the ablest dramatic critics of our country. He analyses a comedy, ancient or modern, with the happiest skill and feels every resource of interest developed in the progress of the fable. ${ }^{35}$ On the other hand, The British Review for

${ }^{30}$ The Observer, No. 94.

31 See The Observer, No. 50.

32 Compare pages 1, 129, 251-2.

33 See pages $283-4$.

${ }^{34}$ See pages $107-9$.

${ }^{35}$ Memoirs of the Life of John Philip Kemble, 132-3. 
October, I 817, remarks: 'It is easy to see that Cumberland knew nothing of Shakspeare. In the lack of analytical criticism he flies to declamation and metaphor.' Cumberland's zeal for learning extends to the point of wishing that actors might possess a classical education. $\mathrm{He}$ declares that the actor should live and have his being in Shakespeare. Cumberland's conception of an actor's mental attitude is an elaboration of his old theme. Actors, he says, should steel themselves against praise or blame. 'That proper sense of himself, which holds a middle place between diffidence and arrogance, is what he must oppose to these attacks of extravagant applause or illiberal defamation. ${ }^{36}$ All that Cumberland says of the calumny against this profession he clearly thinks applicable to his own: 'It is an act of aggravated cruelty to attack a man, whose profession lays him so continually at mercy, and who has fewer defences than other men to resort to. An actor has a claim upon the public for their protection, whose servant he is; and he ought to be dear to every man in particular, whose heart he has dilated with benevolence, or lightened with festivity. ${ }^{38}$

Cumberland has followed the device of his model, Addison, in carrying a story through several essays. The first of these narratives is concerned with a curious attack upon pedantry in woman,-an attack which seems difficult to understand in view of the fact that Cumberland's mother was Joanna Bentley. The Observer visits Lady Thimble, 'one of those female pedants, who with quick animal spirits, a pert imagination, great self-conceit, and a homely person, sets herself up for a woman of talents. ${ }^{37}$ After being brought into a freezing room containing little but a bust of Apollo, he is forced to listen

36 The Observer, No. 29.

37 Ibid., No. 4. 
to the reading of an epic poem written by a boardingschool girl of seventeen. The Observer saw in this pretty girl, named Calliope, one whom 'nature meant . . . to be most amiable and modest, if flattery and false education would have suffered her good designs to have taken place. ${ }^{38}$ Finally, the kindly Observer rescues Calliope from the sea of infidelity into which her youthful mind has plunged her, and soon afterwards learns her unhappy story. For Calliope's lover has been estranged by her very excess of learning. The effect upon Calliope of the news of her lover's return and the unhappy sequel she thus describes to the Observer: 'The joy this letter gave me set my spirits in such a flow, that in the habit I was of writing verses, I could not bring my thoughts to run in humble prose, but giving the reins to my fancy filled at least six sides with rhapsodies in verse: and not content with this . . I I enclosed a fair copy and sent it to him in a packet by the stage coach.' Henry Constant's surprising reply was, in part: 'Though there cannot be in this world a task so painful to me, as what I am now about to perform, yet I think it an indispensible [sic] point of honour to inform my late most lovely and beloved Nancy, that if I am to suppose her the author of that enormous bundle of verses I have received from her hand, it is the last favour that hand must bestow upon her unhappy Henry. ${ }^{\prime 39}$ We may believe Cumberland's attitude to have been not unlike that of Henry's: 'For God's sake,' writes he, 'what have women to do with learning ?' ${ }^{\circ}$ In the next paper Calliope and Henry are united in a flood of sentiment, but the evil results of educating women too highly were shown, the Observer

${ }^{38}$ The Observer, No. 5.

39 Ibid., No. 6.

40 Ibid., No. 6. 
seems to think, by an incident after the marriage. Calliope writes her new friend: 'I had almost forgot to mention to you a circumstance, that passed as we were sitting at table after dinner, and by which our good friend the Vicar undesignedly threw me into a confusion that was exceedingly distressing, by repeating some verses from Pope's Essay on Man, in which he applied to me to help him out in his quotation: I certainly remembered the passage, and could have supplied his memory with the words; but Henry being present, and the recollection of what had passed on the subject of poetry rushing on my mind, at the same time that I thought I saw him glance a significant look at me, threw me into such embarrassment on the sudden, that in vain endeavoring to evade the subject, and being pressed a little unreasonably by the Vicar, . . . I could no longer command myself, but burst into tears.

In the Tragic story of a Portuguese gentleman, who died by the rack is to be seen the author's taste for the melodramatic which found expression in such plays as The Carmelite. Cumberland's sentimental prose style is at its height in the papers on Melissa. ${ }^{42}$ It is the style of his novels in parvo: 'As he was uttering these words,' so runs the dénouement of the tale, 'he threw himself on his knees, snatched the hand of Melissa, pressed it eagerly to his lips, and smothered it with ardent kisses; then applying his handkerchief to his eyes, dropped his head upon Melissa's knee, and in a trembling voice cried out"Speak, loveliest of thy sex, pronounce my fate, determine me for life or death; for, by the power that made me, I will not survive the sentence of despair." ", 43

41 The Observer, No. 7.

42 Ibid., Nos. 23, 24.

43 Ibid., No. 24. 
Cumberland's benevolent, or, from the modern point of view, sentimental regard for the Jews is made apparent in nine papers of The Observer. After a general discussion of inhumanity towards the Jews, a letter is printed from Abraham Abrahams, doubtless the prototype of Sheva. 'I observe with much concern,' says this imaginary person, 'that your great writers of plays take delight in hanging us up to public ridicule and contempt on all occasions: if ever they are in search of a rogue, an usurer, or a buffoon, they are sure to make a Jew serve the turn: I verily believe the odious character of Shylock has brought little less persecution upon us poor scattered sons of Abraham, than the Inquisition itself., ${ }^{44}$ Another paper determines the relation of Shylock to Nashe's Unfortunate Traveller. In the next seven papers, under the history of Ned Drowsy, is a further account of Abrahams and his benefactions. Throughout these essays are touches characteristic of Cumberland. Ned is the typical good-humoured hero of sentimental comedy. He is one whose father "had too tender a concern for his health and morals to admit him of a public school, and the same objections held against an university. ${ }^{, 45}$ In addition, he has all the sentiment needful for a lover of Constantia. The story of the couple united by a benevolent patron has the distinguishing mark of sentimental comedy.

In our second division of The Observer papers, we have Cumberland in the rôle of critic. He discusses Clarissa, whose moral tone he ardently commends. ${ }^{46}$ When not led astray by personal feeling or lack of perspective, as in the cases of Gray and Goldsmith, Cumberland is a

44 The Observer, No. 38.

45 Ibid., No. 40.

46 Ibid., No. 27. 
suggestive critic. His critical faculties are, however, attracted almost exclusively by classic productions, or plays modelled upon the classics. The papers on Shakespeare with the comparisons of Macbeth and Richard and of Shakespeare himself with Aeschylus are effective bits of popularized scholarship. In regard to the two English tragedies, Cumberland says: 'It is manifest therefore that there is an essential difference in the development of these characters, and that in favour of Macbeth: In his soul cruelty seems to dawn, it breaks out with faint glimmerings, like a winter-morning: In Richard it flames forth at once, mounting like the sun between the tropics, and enters boldly on its career without a herald. ${ }^{{ }_{47}}$ Falstaff he calls a 'character, which neither ancient nor modern comedy has ever equalled, which was so much the favorite of its author as to be introduced in three several plays, and which is likely to be the idol of the English stage, as long as it shall speak the language of Shakespeare. ${ }^{48}$ It was natural for Cumberland to discover Ben Jonson's indebtedness to Philostratus, ${ }^{49}$ and to praise his speed in the composition of The Fox about which he is enthusiastic as a 'work, that bears the stamp of elaborate design, a strong and frequently a sublime vein of poetry, much sterling wit, comic humour, happy character, moral satire, and unrivalled erudition. . . .50 Samson Agonistes Cumberland thought 'as compleat an imitation of the antient tragedy, as the distance of times and the differences of languages will admit of,' ${ }^{51}$ and considered that Samson himself possessed 'all the

${ }^{47}$ The Observer, No. 69.

48 Ibid., No. 73. .

49 Ibid., No. 74.

50 Ibid., No. 75.

51 Ibid., No. 76. 
terrific majesty of Prometheus chained, the mysterious distress of Oedipus, and the pitiable wretchedness of Philoctetes.' $^{52}$

Cumberland had had his first great dramatic experience in seeing Quin, Cibber, and Garrick in Rowe's Fair Penitent. Perhaps his best piece of criticism is the comparison of this play with The Fatal Dowry of Massinger and Field, an essay written some forty years after the boyhood experience, and included in The Observer. ${ }^{53}$ A detailed comparison leaves the verdict with the Elizabethan play. John Taylor says: 'His observations on "The Fatal Dowry" of Massinger, compared with "The Fair Penitent" of Rowe, which my friend Gifford has introduced in his admirable edition of Massinger's Plays, are ingenious and profound; but it is by no means improbable, that if Rowe had been as distant from him in point of time, and Massinger as near to his period as Rowe, he would have found good reasons for preferring "The Fair Penitent," and his arguments have been as strong in favour of the latter. ${ }^{54}$

The thirty essays upon Greek literature are, perhaps, the most enduring part of The Observer. Here is the material supplied by Bentley, and Cumberland's handling of it has produced a unified and scholarly treatise. 'That series of papers,' Cumberland says, 'will I hope remain as a monument of my industry in collecting materials, and of my correctness in disposing them.' Cumberland's wish has been, in a measure, granted. In the second edition of The Observer, printed in I798, was included

52 The Observer, No. 76.

53 Ibid., No. 77. Cumberland exposes Rowe's pilferings from the Elizabethan play. See The Gentleman's Magazine for July, 1817.

54 Records of My Life, 2.161. 
a translation of The Clouds of Aristophanes. The translation of the comic dramatists appeared in Walpole's Comicorum Graecorum Fragmenta, 1805 , and in Bailey's edition of this work in 1840 .

The third division of essays upon morals, philosophy, and religion reveals Cumberland's personality in a familiar light. To attack gaming, the essayist gives up an entire paper, although he says: 'What avails my hurling a feeble essay at the heads of this hydra, when the immortal drama of The Gamester lies trodden under his feet?' After a long analysis of the evil Cumberland concludes: 'My proper concern in this short essay is to shew, that gaming is the chief obstructing cause, that affects the state of society in this nation, and I am sensible I need not have employed so many words to convince my reader that gamesters are very dull and very dangerous companions. When block-heads rattle the dice-box, when fellows of vulgar and base minds set up whole nights contemplating the turn of a card, their stupid occupation is in character; but whenever a cultivated understanding stoops to the tyranny of so vile a passion, the friend to mankind sees the injury to society with that sort of aggravation, as would attend the taking of his purse on the highway, if, upon seizure of the felon, he was unexpectedly to discover the person of a judge. ${ }^{155}$

Duelling is also strongly censured. After the story of the mortification of the braggart, Leontine, the Observer meditates sadly upon the vice: 'I would seriously recommend to my readers of all descriptions, to keep a careful watch upon their tempers when they

55 The Observer, No. 22. 
enter into argumentation and dispute. ${ }^{58}$ The absurd seriousness of Cumberland's attitude is clear from his appending to his advice fourteen rules to be observed by potential duellists. Some of these are:

Every man who gives a controverted opinion, ought to lay it down with as much conciseness, temper, and precision, as he can.

No two disputants should speak at the same time, nor any man overpower another by superiority of lungs, or loudness of a laugh, or the sudden burst of an exclamation.

If any disputant slaps his hand upon the table, let him be informed that such an action does not clinch his argument, and is only pardonable in a blacksmith or a butcher. ${ }^{58}$

The religious papers in The Observer have to do largely with a defence of the Christian faith, with particular reference to the heathen philosophies and modern scepticism. Later essays treat of the miracles and other aspects of religion.

Notice of the publication of The Observer may be found in The Gentleman's Magazine for May, I785. In the same magazine for November, 1785, appeared a review of the paper with long excerpts: 'Till the publication of the work now before us, the town has not been gratified with any production of this sort since the appearance of the witty and agreeable "Connoisseur." . . To him who devotes his learning and abilities to promote virtue, to strengthen fidelity, and to repress licentiousness, the gratitude of mankind is eminently due. Such is the object of the Observer. . . . As it was remarked of the Spectator, that "he brought philosophy from the dark retreats of science into the verge of society," so to have allured learning from the college ${ }^{56}$ The Observer, No. 18. 
and the cloister to the habitations of common life, is the praise of the Observer. . . .'

The Monthly Review for May, I79I, says of a later volume: 'It would be sufficient to say that the fifth volume of the Observer is like those which preceded it; frequently instructive, though never very deep; always easy, though not always accurate; constantly endeavouring, with the best intentions and the best humour, to promote happiness; and generally endeavoring with success.' This paper disapproves of the essays on the Greek Comic Poets: 'To general readers, these last essays form the least entertaining part of the volume; and to others, who, from their acquirements in literature, may be supposed to relish them, they may appear to be misplaced. To open the hidden stores of Grecian poetry to the inspection of the unlearned, may be pleasing and even useful: but to pass judgment on the merits of ancient writers, from the translation of a few mutilated fragments, is neither judicious nor beneficial.' The highest praise came from Nathan Drake, who declared that The Observer, 'though the sole labour of an individual, is yet rich in variety, both of subject and manner; in this respect, indeed, as well as in literary interests, and in fertility of invention, it may be classed with the "Spectator" and "Adventurer"; if inferior to the latter in grandeur of fiction, or to the former in delicate irony and dramatic unity of design, it is wealthier in its literary fund than either, equally moral in its views, and as abundant in the creation of incident. I consider it, therefore, with the exception of the papers just mentioned, as superior, in its powers of attraction, to every other periodical composition. ${ }^{{ }^{5} 7}$

57 Drake, Essays, Illustrative of the Rambler, Adventurer, and Tatler, 2.393-4. See also Correspondence of William Cowper, Wright ed., 3.336. 
On the other hand, Fanny Burney, who was exceedingly angry at Cumberland for his satire upon Mrs. Montagu in the essay entitled The Feast of Reason, found in The Observer little to admire: 'I am heartily averse,' she says, unforgetful, perhaps, of the Evelina incident, 'to any work of any species, that contains such hard personalities; and I think the Observer, besides little more than a compilation from some classic scholar's commonplace book: for all that is not personal is criticism on Greek authors and customs. ${ }^{58}$

At the completion of the series, the entire collection of essays, embodying the Comic Fragments, was printed in a five-volume edition. In 1798 Cumberland added his translation of The Clouds, and issued a new edition in six volumes which was added to The British Essayists. 'I consider,' Cumberland says, 'the Observer as fairly enrolled amongst the standard classics of our native language.' The Observer contains some of Cumberland's best non-dramatic work, and was perhaps his most successful attempt outside the field of sentimental comedy.

Had you lived in London in 1785 you would have eaten, perhaps more than once, if you had been an intellectual bon vivant, at the table of Mr. Samuel Dilly. This gentleman, to quote Cumberland, 'kept a table ever open to the patrons and pursuers of literature, which was so administered as to draw the best circles together, and put them most completely at their ease. . . Under this roof the biographer of Johnson . . passed many jovial joyous hours; here he has located some of the liveliest scenes and most brilliant

${ }^{58}$ Diary and Letters of Madame D'Arblay, Dobson ed., 3.71-2. Austin Dobson says: 'Sir Fretful would have winced at this.' Ibid., 3.72, footnote 1. 
passages in his entertaining anecdotes of his friend Samuel Johnson, who yet lives and speaks in him.' Here on an evening of this year you might have found Cumberland in earnest conversation with Samuel Parr, pedagogue and distinguished scholar. The colloquy was characteristic on both sides; the two parted as enemies. Parr later sent word to Cumberland that he was convinced that 'his ignorance was only excelled by his impudence, and his impudence was only excelled by his malice. ${ }^{59}$ The basis of Cumberland's grievance may be found in his declaration that Parr had attacked a friend. $\mathrm{He}$ 'conceived that Doctor Parr had hit an unoffending gentleman too hard, by launching a huge fragment of Greek at his defenceless head.' ${ }^{60}$ Cumberland's views were finally presented in an anonymous tract, published in 1783 , called Curtius Rescued from the Gulph. Mudford, the biographer of Cumberland, says that Parr deigned no response. Not long after this encounter, Cumberland's love of debate, long nourished in university classrooms, found expression in an assault on the Bishop of Llandaff, who had sought to equalize the revenues of the hierarchy and dignitaries of the church. The argument was declined by the churchman, and Cumber-

59 See Barker, Literary Anecdotes, 1.63.

60 Mudford declares that Cumberland heartily enjoyed controversy. His first bout had been with Bishop Lowth. In 1765 Lowth and Warburton had engaged each other till, as Cumberland said, 'their very hands blushed and their lawn sleeves were bloody.' One of Lowth's pamphlets had a sneer at Bentley, who was styled aut caprimulgus aut fossor. Upon his uncle's refusal to break a lance, Cumberland entered the lists, armed with a monstrously titled pamphlet to which was affixed the legend: Jam parce Sepulto. The Bishop, however, did not deign a reply, and the pamphlet's only result-a rather ludicrous one-was the bestowal of a gift and letter of gratitude upon Cumberland's uncle, who was deemed the author. See The Gentleman's Magazine for April, 1806, and The Edinburgh Review for June, 1818. 
land believed himself to have come off the better. But The Gentleman's Magazine refers to a 'letter from Richard Cumberland, Esq. containing some wit, but not much argument or candour; and which was ably answered by another ingenious writer.' Alas for dialectic! Bad plays were better than ventures of this kind.

In 1787 the dramatist had offered a new play, The Country Attorney, to George Colman. While Colman had promised blithely to produce the play, he doubtless had misgivings; he had laughed more than once with Garrick over Cumberland's idiosyncrasies. In particular, he detested the sentimental tone into which the dramatist was likely to lapse. 'Whatever favours are bestowed upon it,' Cumberland wrote Colman in regard to the play, 'must be derived from your friendly attention and judicious support of it. ${ }^{11}$ This phrasing does very well, but, when Cumberland goes on, we can imagine Colman's shaking his head and thinking he would show this letter to Garrick: 'As for your part, my dear Sir,' writes the dramatist, 'from beginning to end, it has been such as leaves the most kindly impressions on my heart towards you. I wish the production had been more deserving of you, but the zeal of its author will, in your estimation, make up all deficiencies in the work itself.'

In rehearsing The Country Attorney, difficulties a rose. Miss Farren, Cumberland's favourite actress, would have none of her part. 'Miss Farren,' Cumberland wrote his manager petulantly, 'is a spoiled child, and has done us more mischief by her hesitation than she could have done by a more peremptory refusal. ${ }^{62} \mathrm{Mrs}$.

61 Peake, Memoirs of the Colman Family, 2.209.

62 Ibid., 2.206. This letter is quoted as a memorial of Cumberland's character. See The Gentleman's Magazine for February, 1834. 
Brooks $^{63}$ was established in the rôle, but Colman still thought that Miss Farren might be recaptured, if a trump card were played, and Cumberland, accordingly, wrote, with effective tact, a letter which placated the coquettish actress. 'I am convinced,' he wrote his idol, 'that it is not in my power either to write the rôle up or to write it down; that having tried hard for the former attempt in the character of Lady Paragon, I now put your excellence to proof, by desiring you to convince the town that Lady Rustic cannot diminish your reputation with the public, and will greatly add to your private merits by protecting the weak and feeble, who cannot stand without your support.' The success of the actress in The Natural Son had brought Cumberland to her feet; yet he was not prepared to write a letter of this sort without demanding from Colman a compensation. 'For heaven's sake,' he says, 'write her an Epilogue.'

The Country Attorney was acted at The Haymarket Theatre on July 7,1787 ; it barely deserved its run of a half-dozen nights.

Boaden gives a faint idea of the plot of The Country Attorney. It is based upon the 'stale incident of introducing the unknown wife of a son to his father, to captivate him with her accomplishments, and producing a reconciliation, by showing the old gentleman, that his boy had done the very thing which alone could satisfy the father. ${ }^{\prime}{ }^{64}$

The General Magazine for July, however, contains a kindly account of Cumberland's moral attitude in The Country Attorney. 'In most of his comic productions,' the reviewer says, "it has been the laudable aim of this

${ }^{63}$ Mrs. Brooks first appeared at the Haymarket in 1786 as Lady Townley in The Provoked Husband.

${ }^{64}$ Memoirs of the Life of John Philip Kemble, 209. 
author to discountenance and to explode, as much as possible, some popular and vulgar prejudice, and to shew the illiberality and absurdity of national reflections and general censure on particular professions. In this comedy Mr. Cumberland honours the profession of the law with a defence and a lesson, by exhibiting as his principal character, an attorney of inflexible integrity, who, by not only refusing to make a will in his own favour, but inducing the testator to bequeath the chief part of his property to a destitute, but worthy relation, gives a happy termination to the plot . . . It contains nothing particularly striking. . . The dialogue is such as not to disgrace the pen of $\mathrm{Mr}$. C. and though it does not abound in wit or humour, and is, perhaps, the least happy of his comic efforts, yet it is so far respectable as to do no injury to a preestablished and eminent character, and the previous exertions of higher excellence.'

The European Magazine for July, in noting the failure of the play, says: 'It had no novelty, and but little to commend either in character, humour, or wit; though it possessed some merit in the easy, and in a few places appropriate dialogue. It was represented with great excellence by the actors but was so coldly received by the audience as to be laid aside after four performances. A Prologue by the author was spoken by Mr. Bensley, ${ }^{65}$ and an Epilogue by Mr. Colman, by Miss Farren.'

Not less surprising than the number of Cumberland's plays is his zeal for all other forms of literature. Per-

65 Robert Bensley's first appearance on a London stage was at Drury Lane Theatre on October 2, 1765, as Pierre in Venice Preserved. Bensley was at Covent Garden from 1767 to 1775 , and from 1775 to 1796 he alternated between Drury Lane and the Haymarket. Charles Lamb says of him that of all actors 'Bensley had most of the swell of soul. . . . He had the true poetical enthusiasm, the rarest faculty among players.' 
haps the most audacious attempt of these years was that of novel-writing. The plays of twenty years attest by allusion and even by discussion his deep interest in the masterpieces of eighteenth century novelists. During a summer at Brighthelmstone in 1788 he hastily threw together the novel of Arundel. The work was quickly cast aside, and made no impression on a world surfeited with moral imitations of Richardson and Fielding. Arun$d e l$ has, nevertheless, interest for the light which it throws upon the new novelist.

Francis Arundel, a young scholar, enters the household of the Earl of G. as his private secretary. Unhappy family relations between the Earl and the Countess make Arundel the object of the Countess's affections, and he is also beloved by her daughter, Lady Louisa. Other personages are Sir George Revel, a dissipated suitor of Lady Louisa, Sir Joseph Arundel, an unnatural father, a benevolent uncle, Admiral John Arundel, and the respective correspondents of Arundel and Louisa, namely, Charles Mortlake and the Lady Jane S. The plot's mid-point is a duel between Arundel and Revel. Normal readjustments take place by the means best known to sentimental comedy. The Earl and the Countess are reunited, Revel is checkmated, and two pairs of lovers join hands.

The story is told, to the utter exclusion of real action, in a long succession of letters, and the tone and language of the novel are sentimental beyond pardon. Scott's words are the most charitable: 'The style . . . was easy and clear, and the characters boldly and firmly sketched.' The novel has one other virtue: 'It shews,' says Scott, 'at the first glance what is seldom to be found in novels, the certainty that the author had been well acquainted with 
schools, with courts, and with fashionable life, and knew the topics on which he was employing his pen. ${ }^{66}$

The situation of Arundel in the family of his patron is too like Cumberland's with Lord Halifax not to be autobiographical. Arundel writes Mortlake: 'The scene I am now entering upon strikes my senses with its novelty, but it does not satisfy my mind. . . How it may be, when I am more familiarized to the modes and manners of the great world, I cannot pretend to say. . . . My slender stock of acquirements has been purely of the literary sort; and having known no other training than in the fellowship of the muses, inter Sylvas academi, I shall be an awkward novice in the circle of the courtly graces. $^{{ }^{67}}$ Otherwise, the story has little reference to Cumberland's life, unless the Earl of G. be meant for Lord Halifax, in which case the character is considerably darkened.

Duelling, censured already in play and essay, does not escape in the novel. Mortlake's letters to Arundel, respecting the approaching duel with Sir George Revel, are, in reality, sermons: 'I know you too well,' he writes, 'to believe he has any interest to divert your mind from the most rigid adherence to those sanguinary laws, which honor, (that Moloch of the world's idolatry,) has imposed upon its votaries. . . I have hitherto supposed that the laws of our country gave us redress against assaults; but when men of principle, lovers of justice . . . do not apply to these laws, how can I suppose any such are in existence? Duelling it seems then is the only bond of society, the safeguard of our personal rights,

${ }^{66}$ Novels of Swift, Bage and Cumberland, 'Prefatory Memoir to Cumberland,' 54.

${ }^{67}$ Arundel, Letter 1. 
our sole preservation against violence; strange paradox this.'

The reader has seen that Cumberland's ambition had attempted poetry. The playwright, essayist, and novelist longed to be known as a poet. Yet it is to be feared that he never advanced beyond the mere maker of rhymes. Besides the long epic poem which was to appear in a few years, and the early attempt at blank verse, the elegiac $V$ erses on the death of the Prince of $W$ ales, the verse translation of the Georgics, the Elegy on St. Mark's Eve, and the Lines on the Discovery of India were all experimental and youthful poetry. In addition there are accessible in the Memoirs fragmentary poetic effusions such as the dedication to Romney, the lines to Lord Mansfield, and to Richard Sharpe. There are, likewise, the verses to the Storm, and the verse translation of the Bible. Cumberland prints in the Memoirs a series of 'fugitive poems' with the following titles: Wit, Affectation, Vanity, Avarice, Prudery, Envy, Pride, and Humility.

Very few of these poems were published, nor was any attempt made to collect them all. The lines $O n$ the Marriage of Miss Sackville to Mr. Herbert appeared in The Gentleman's Magazine for May, I782, and the verses on Envy were printed in the same magazine for August, I 79I.

We must finish the few remaining years of this period of Cumberland's life with a chronicle of still more unsuccessful plays, bearing witness not only to failing powers but to an industry untempered by judgment or restraint. Another West. Indian the public would have welcomed, but Cumberland had none to give. His energies were spent in revisions, operas, and occasional pieces. The troubled ghost of The Country Attorney was not suffered 
to rest, but appeared two years later, on May 8, I789, at Covent Garden Theatre, as The School for Widows. The play was acted only three times, but pleased the sentimental clientèle. A poem which it inspired found its way into one or two of the dramatic memoirs of the time. Some of the more normal lines ran :

This drama was by Cumberland design'd

To form the manners, and improve the mind;

His muse her characters from nature draws,

Writes to the heart, and seeks from that applause.

But the opinion of The General Magazine held sway. 'The productions of this master, indeed,' says the reviewer, 'succeed each other so rapidly that it is not to be wondered at if a muse, thus jaded, should become "dull and unpleasing." The Impostors, performed at Drury Lane on January 26, I 789, failed, but was distinguished by a vivacious plot. The adventures of the two free-lances, Harry Singleton and his friend, Polycarp, recall Cumberland's lighter and happier style. The European Magazine for January expresses the feeling of the reader of today when it says that the comedy, 'like everything written by $\mathrm{Mr}$. Cumberland, is not excellent in itself, but has merit sufficient to show it to be the production of a person who would be able to do better, were he to exert the full force of his genius.' The Occasional Prelude, which appeared at Covent Garden on September I7, I 792, may be disregarded, as well as the comic opera of The Armourer, produced on April 4 of the next year. The latter was trimmed by the censor, though, as Genest says, 'certainly no one but a dog in office could suspect Cumberland of writing anything with 
a bad political tendency. ${ }^{188}$ The Box Lobby Challenge, a comedy not without wit and cheerfulness, was acted at The Haymarket Theatre on February 22, 1794. It enjoyed a run of twelve nights, and may be grouped with The Impostors as reminiscent of Cumberland's earlier triumphs in sentimental comedy. These two plays were pledges of the return of the old power.

68 See Aicken, About the Theatre, 119. 


\section{CHAPTER XIII}

\section{RENEWED SUCCESS.-THE JEW.-THE WHEEL OF FORTUNE}

CUMBERLAND'S renaissance of power came in two plays, The Jew, acted at Drury Lane Theatre on May 8, I794, and The Wheel of Fortune, which appeared at the same playhouse on February 28, I795. The dramatist's fame rose with mercurial speed. 'The Jew,' says Boaden, 'became popular all over these islands.' ${ }^{1}$ The play was acted many times in America; the mighty actor Theodore Döring made it famous in Germany; and it was imitated on the Parisian stage. Many dramatic vicissitudes had failed to staunch Cumberland's flow of sentimentalism. The Jew dissolved its audiences in tears; it leaves its readers today in wondering amusement.

Frederick, son of Sir Stephen Bertram, a worldlyminded merchant, has secretly wedded Eliza Ratcliffe. This marriage antagonizes Sir Stephen, who objects to the fortuneless Eliza; it angers also the proud-spirited brother, Charles Ratcliffe, who sees in the union an aspersion upon the family honour. The overshadowing theme is the benevolence of Sheva, the Jew. Sheva bestows a dowry upon Eliza, thus rendering her acceptable to Sir Stephen, and as Charles and Frederick are about to fight, he separates and reconciles them. Thus the Jew is, in the words of Charles, nothing less than 'the widow's

1 Memoirs of the Life of John Philip Kemble, 329. 
friend, the orphan's father, the poor man's protector, the universal philanthropist.' ${ }^{\prime 2}$

Cumberland's moral attitude stirred all the critics to approval. 'The benevolent design of the author in this play appears to have been,' says The Analytical Review for December, 'to rescue an injured and persecuted race of men from the general reproach which has fallen upon them, by exhibiting one of that body as uniting with the peculiarities of his sect eminent virtues.' 'To conquer the illiberal prejudices of mankind,' says the May Universal Magazine, 'and level the repulsive and uncharitable distinctions of sect and of country, have been objects, which [Cumberland] has nobly aimed at, and in which we have pleasure in admitting he has not been without success. Of this amiable nature is his motive in making a Jew the hero of a modern comedy.'

The tender sensibilities of the eighteenth century were deeply moved, for the same paper declares that a 'rude outline of the fable . . can convey no idea of the merit and beauties of a drama in which human nature is represented in the most amiable colors, and in which the most forcible appeals are momentarily made to the heart. Tears are involuntarily forced in many places, by the finest touches of philanthropy; while the mind is very artfully relieved by occasional scenes of humour. . . .'

The Jew, like so many of Cumberland's plays, is a single-character comedy. Criticism of the play narrows itself to criticism of the character Sheva. The benevolent Jew was a unique feature in dramatic literature. The Monthly Review for February describes clearly the conventional stage Jew. 'Whenever,' it says, 'the character of a Jew has been exhibited for the entertainment

2 The Jerw, 5.2. 
of the public, it has not been thought sufficient to expose his national peculiarities to ridicule, but he must be also holden up to infamy as a bloodthirsty villain, a hardhearted usurer, or a sly and pitiful knave. The practise has so successfully rooted illiberal and vulgar antipathy to the unfortunate descendants of Abraham, that few people perhaps now hear a Jew mentioned, without thinking of the cruel Shylock, or of cunning little Isaac.' 'Several years ago,' continues The Monthly Review, 'in the 6th number of "The Observer," Mr. Cumberland remarked the absurdity and inhumanity of this practice, and, with his usual elegance, illustrated the subject by introducing a letter of complaint from a Jew. In the postscript, Ab. Abrahams adds, "I hope I shall not give offense if I say, that if you could persuade one of the gentlemen or ladies who write plays to give us poor Jews a kind lift in a new Comedy, I am bold to promise we should not prove ungrateful on a third night." This kind lift Mr. Cumberland himself has given them. He has written a comedy, the principal design of which is to exhibit on the stage the character of an honest and charitable Jew; and the task is executed with the same soundness of judgment and elegance of taste which have distinguished Mr. C's former productions.' Thus, 'it was;' as the critic of The Universal Magazine declares, 'reserved for the mild and masterly pencil of $\mathrm{Mr}$. Cumberland to give him [The Jew] those fine tints of nature which clothe him in the dignity of a man.'s

The boldness of Cumberland's venture must be admitted. His conception was of a Jew who is apparently a usurer and a miser, of one who 'appears to be the general benefactor, and has the felicity of seeing the

3 The Universal Magazine, May, 1794. 
whole party made happy by his bounty.' Cumberland consciously designed to show 'under the cloak of extreme avarice, Sheva, a jew broker,' who 'conceals a heart susceptible of the tenderest pity, and endued with the warmest charity.'

Admirable as may have been Cumberland's altruism in so depicting Sheva, it is difficult to comprehend Boaden when he says that he is 'at least as natural a character as Shylock, ${ }^{15}$ or to credit the magazine critiques which call him a portrait from life. Cooke, the actor, enjoys a better perspective: 'Cumberland's muse,' he says in his Journal, 'is a philanthropic one, and painted men as they should be, rather than as what they are. . . Sheva is highly overcoloured. A man of immense wealth, starving himself to do good to others, is improbable. ${ }^{\prime}$ The British Critic, also, sees more clearly that the character is a fiction: 'That a Jew should possess,' it says, 'the feelings of a man and the virtues of a Christian; that such a Jew, if opulent and wealthy, should be secretly charitable, and make an indigent Christian his heir, are surely probable things, in defiance of vulgar prejudice; but that with qualities like these should be connected avarice abroad and parsimony at home, usury in his contracts and cruelty to his domestics; that his good deeds should take so perfectly the resemblance of bad ones; and that his humanity, alive to strangers, should be dead to those of his own household, are circumstances which appear to pass the line of probable events. Admitting them credible, they would offer such an unnatural alliance of the best, with the worst qualities, as would effectually violate the properties of comedy; whose

4 The Analytical Review, December, 1794.

5 Memoirs of the Life of John Philip Kemble, 328.

6 Dunlap, Life of George Frederick Cooke, 1.366. 
office is to reflect the features of human life in its more usual and general forms.'

To the modern reader Sheva can seem only ludicrous. A mixture of sentimentality and bad humour, he is merely laughable. Yet it must be remembered that Sheva is an example of Cumberland's moral idealism. Sheva's curtain speech is suggestive of the prejudice Cumberland hoped to shatter. Of his 'mine of wealth' Sheva says: 'I do not bury it in a synagogue, or any other pile; I do not waste it upon vanity, or public works: I leave it to a charitable heir, and build ma [sic] hospital in the human heart!'s

The róle of Sheva brought out the genius of numerous actors. John Bannister watched the part grow 'act by act.' 'Never,' says Adolphus, his biographer, 'was the confidence of an author more amply repaid, or his hopes more abundantly gratified or even exceeded. In every passage the feelings of the audience were at his entire command. They tranquilly approved, they laughed, they wept, they yielded to every emotion which the actor sought to impart; and their applause, like their sensibility and their delight, was unbounded.' Another actor of Sheva was Robert Elliston, called by Charles Lamb 'the second tragedian on the stage,' and 'the best lover on the stage both in tragedy and comedy." A characteristic anecdote is told of Cumberland at the time that Elliston had the part of Sheva. 'The Jabel of the night entering the room, dressed for the afterpiece was by $\mathrm{Mr}$. Cumberland's desire presented to him. He delighted the young comedian, by assuring him that the part had never been better played; and that in figure, dress, and

7 The British Critic, July, 1795.

8 The Jew, 5.2.

${ }^{9}$ Memoirs of John Bannister, 1.338. 
acting, he was the very thing he (the author) had intended. "I wrote the part, and ought to know-it was perfect. I assure you, sir, I never was more gratified; but" (with irrepressible irritation) "you spoke so low, I couldn't hear a word you said." '10 Sheva was also acted by William Dowton, the versatile comedian of Drury Lane, renowned for his performance of Malvolio.

Other dramatists and Cumberland himself watched with interest the effect of this play upon the Jews. It is, however, almost certain that they made no attempt to express gratitude if, indeed, they felt any such emotion. 'When Charles Surface was ill (says Sheridan) the Jews put up prayers for him in the synagogue-and some such tributary unexpensive acknowledgments might now have been made by the Goldsmids and the Solomons to Mr. Cumberland. ${ }^{11}$ Certain magazines implied that Cumberland would not be insensible to such praise: 'The author has made the Jew act like a Christian, in opposition to Shakespeare's Shylock. Though the author cannot claim the applause of the critics for this piece, he will doubtless have the thanks of all the Israelites. ${ }^{12}$ Cumberland admits in the Memoirs that he wished tokens of Jewish pleasure: 'I will speak plainly on this point; I do most heartily wish they had flattered me with some token; however small, of which I might have said this is a tribute to my philanthropy, and delivered it down to my children. . . .' That recognition of his 'appeal to the charity of mankind' by the portrayal of Sheva was lacking, is evident from the Memoirs: 'The public prints gave the Jews credit for their sensibility in acknowledging my well-intended ser-

10 Mrs. Mathews, Memoirs of Charles Mathews, 1.243-4.

11 Boaden, Life of Mrs. Jordan, 1.264.

12 The Lady's Magazine, May, 1794. 
vices: my friends gave me joy of honorary presents, and some even accused me of ingratitude for not making public my thanks for their munificence . . . but not a word from the lips, not a line did I receive from the pen of any Jew, though I have found myself in company with many of their nation.' Oxberry tells the following anecdote of Cumberland's later feelings towards the Jews: 'It was reported that $\mathrm{Mr}$. Cumberland had received a handsome present from the Israelites, in consequence of the white-washing, or rather gilding, he had given them in his Jew. This report induced a gentleman to ask him the question. "No," said Mr. Cumberland, "They gave me nothing; and to tell you the truth, I am glad of it; for if they had, in all probability I should have been indicted for receiving stolen goods." '13 Cumberland's final gibe for the Jews was: 'If I have said for them only what they deserve, why should I be thanked for it? But if I have said more, much more, than they deserve, can they do a wiser thing than hold their tongues?'

Boaden's view of the ingratitude of the Jews was like Cumberland's: 'Mr. Cumberland deplores the "ridicule and contempt" with which they have been treated on the stage, till Sheva, as I presume he thought, did them justice. Their character is retrievable when Sheva is not extraordinary among them. . . . ${ }^{14}$ The reader of today

\section{Dramatic Biographies, 5.214.}

${ }^{14}$ Life of Mrs. Jordan, 1.265. See also Mrs. Inchbald, The British Theatre, 18, Dunlap, Memoirs of the Life of George Frederick Cooke, 2.59, and Genest, 7.150-1. The Jew probably influenced Dibdin's play, The Jew and The Doctor. Cumberland read the play for Dibdin. See Oulton, History of the London Theatre, 2.43. Colman alludes to The Jew in his Sylvester Daggerwood, 3. The prologue and epilogue of The Jew were published in The European Magazine for May, 1795, and The Lady's Magazine for June, 1795. See also Notes and Queries, 9.5.416, 479 . 
immediately finds an explanation for the silence of the Jews in regard to the play, namely, that Sheva is too ridiculous to merit thanks. The Jew may amuse, may even please, but can hardly inspire a people's gratitude.

The Wheel of Fortune has often been praised as Cumberland's second-best play. At the opening of the play Roderick Penruddock is shown far from the haunts of men, in loneliness and despair. Cheated of his betrothed by his enemy, Woodville, he has lived for twenty years sunk in sadness and misanthropy. $\mathrm{He}$ learns with exultation of a strange trick of fortune; an inheritance long destined for Woodville has suddenly become his; with all the passion of a Borgia he consecrates himself to revenge. But while searching in London for his ancient enemy he meets young Henry Woodville; hatred for the boy's father is softened in a thousand tender recollections of the mother, Penruddock's lost Arabella. He hears with understanding of young Woodville's love for Emily Tempest, and begins to shrink from a revenge which shall involve in its ruin so many innocent lives. Stung beyond measure by the reproaches of his conscience and stirred by the appeals of Sydenham, the friend of Woodville, Penruddock repents, forgives Woodville, and bestows a fortune upon the lovers.

A few dissentient voices among the critics were lost in a general outburst of praise. The March number of The Lady's Magazine, the regular decrier of Cumberland, declared that the success of The Wheel of Fortune was more decided than that of any comedy since The School for Scandal and was likely to be nearly as permanent.

If this praise was not undeserved it was due to the 


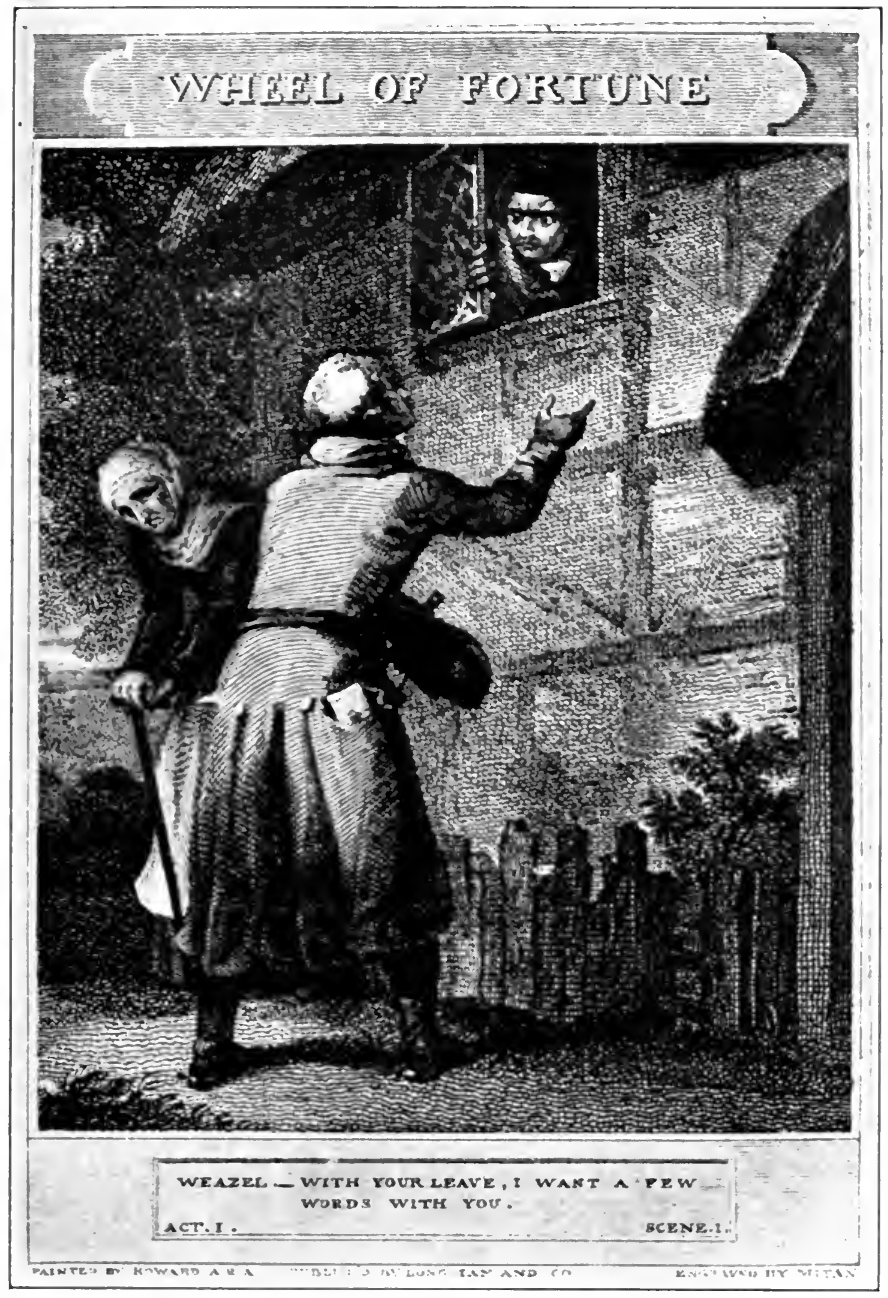



power of 'the pale, unhappy' Penruddock,' who 'seems to take possession of the attention and of the heart,' and who 'weakens the interest of everything in which he is not immediately concerned.' 'Penruddock,' says The Monthly Review for April, 'so entirely swallows up the lean kine by which he is surrounded, that we scarcely know that such beings have existence.'

Penruddock was successful on the stage because he combined keen interest "with the strength of the desired moral appeal. It should be noticed that the design of revenge upon Woodville is but a superficial thing. At every point the villain pauses, and indulges in sentimental reflections; his final repentance is a foregone conclusion. When he has 'the despoiler of [his] peace'15 at the pistol's point, he is disconcerted by a note, and though described by Henry Woodville as 'a gloomy misanthrope shunning and shunned by all mankind, ${ }^{18}$ his only revenge is to tell young Woodville the story of his father's guilt. As early as the second act Penruddock speaks of the 'mercy in his bosom, ${ }^{17}$ and when Sydenham reproaches him at the end of the third, we know that his plan is laid aside. This is very far from sweeping to a revenge, or issuing, 'like a hungry lion from his den, to ravage and devour. ${ }^{18}$ Penruddock lacks spine. His repentance springs not from self-conquest, but from irresolution. The misanthrope's first thoughts on his return to London are the natural ones for a man bent on revenge: 'Within me anarchy and tumult! Thoughts uncollected, jarring resolutions, avarice, revenge, ambi-

15 The Wheel of Fortune, 3.3.

16 Ibid., 2.3.

${ }_{17}$ Ibid., 2.3.

18 Ibid., 2.3. 
tion. . . . ${ }^{19}$ But at the home of his 'once-beloved Arabella' ${ }^{\prime 20}$ he wavers: 'Here . . . she wrote that melancholy appeal, which wrung the weapon from my hand, when raised against her husband's life. I'll read it once again; the scene conspires, a sympathetic gloom comes over me. ${ }^{\prime 20}$ Such speeches do not move the modern reader. $\mathrm{He}$ prefers a more relentless vengeance, and a more natural repentance.

But Penruddock is more than the ordinary sentimental comedy hero. Difficult as it is to analyze, there is, in the character, an unusual depth and power. Cumberland was, for a time, at least, gifted with insight to depict an affectionate nature deeply wronged. Some of Penruddock's speeches sound the deep notes of pathos. In 1838 Dunham wrote that the character still kept possession of the stage, and that he believed it would live $;^{21}$ Mudford thinks it Cumberland's best character ${ }^{22}$ and Scott thought so highly of it as to place it in a novel. ${ }^{23}$

The acting of The Wheel of Fortune centres in the part of Penruddock. Innumerable tributes to Kemble's acting in this rôle exist. One of the best is Boaden's: 'I was now very frequently with Kemble, and know the great pains he took with the character of Penruddock in the Wheel of Fortune. It came at length upon the stage, on the 28th of February, one of the most perfect impersonations that had ever excited human sympathy. $\mathrm{He}$

19 The Wheel of Fortune, 2.3 .

20 Ibid., 2.3.

21 Eminent Literary and Scientific Men of Great Britain and Ireland, 3.362 .

22 Life of Richard Cumberland, 556-7.

${ }^{23}$ Dunham says: 'Sir Walter Scott, in transferring the character of Penruddock to his tale of The Black Dwarf, gave it to the public in a coarse disguise, and made what was in the original dignified and just, romantic and unnatural.' Eminent Literary and Scientific Men of Great Britain and Ireland, 3.362 . 
had fishioned every sentence of the part to his own organs, so that it seemed a decided reality; and his personal manner was so little disturbed, that the spectator, by an easy delusion, almost fancied that $\mathrm{Mr}$. Kemble was relating some striking misfortunes that had happened, in early life, to himself. I most seriously affirm, that, for identity, Penruddock would hardly admit of competition. Here from the great intimacy between us, he advised with me as to the plain and almost quaker attire he wore; and I saw in his walk, and occasionally in his countenance, the image of that noble wreck of treachery and love, which was shortly to command the tears of a whole people. ${ }^{, 24}$

Comments upon Kemble's acting in the rôle of Penruddock differ only in degree. 'Nothing,' says one critic, 'in dramatic representation can excel the judgment, feeling, and discrimination, with which $\mathrm{Mr}$. Kemble plays this amiable, generous-hearted misanthrope. ${ }^{25}$ 'He acted with spirit, ${ }^{, 28}$ he 'shared . . . the

24 Memoirs of the Life of John Philip Kemble, 338. Michael Kelly, in his Reminiscences [256], tells a story of Kemble: 'About three weeks previous to the bringing out of this play, I went into the prompter's room, and found Kemble, who was going to dine with me, sealing up a parcel. He said, "My dear Mic, desist a moment until I send off this to Cumberland; it is a comedy of his which I write to tell him is accepted; and, if I am not greatly mistaken, there is a character in it that will do something for $m e$; at least I feel that I can do something with it. Mind, you and Nancy (meaning Mrs. Crouch) must promise to see me act it the first night." We according did,' continues Kelly, 'and were delighted; and ever after, considered Kemble, Penruddock; and, Penruddock, Kemble. . . .' 'I remember,' says Kelly, 'after poor Suett's death, Kemble, lamenting the event, and saying to me,- "My dear Mic, Penruddock has lost a powerful ally in Suett; Sir, I have acted the part with many Weazles, and good ones, too, but none of them could work up my passion to the pitch that Suett did.",

25 Biographia Dramatica, 4.400.

26 The Lady's Magazine, March, 1795. 
applause with the author, ${ }^{\prime 27}$ are casual selections from long accounts, and particular scenes are abundantly praised. So Genest commends Penruddock's interview with Emily, ${ }^{28}$ and The Universal Magazine for March declares that the "chair scene with the son of his once loved Arabella is, perhaps, at the full height of the mimic art.'

Biographia Dramatica gives a graphic description of Penruddock's indecision in taking his revenge upon Woodville: 'In determining how he shall behave toward the Woodvilles, he keeps up most admirably indeed, the struggle between a desire for revenge for the wrongs he has suffered from his rival, and tenderness for his former mistress. Nor can anything be finer than his exultation when virtue prevails. Serenity seems restored to that mind which has been the scene of the most dreadful conflicts; and he appears truly to feel the glow of complacency which attends the exercise of benevolence. ${ }^{, 29}$ In I 808 Kemble's eminence in the part was still undisturbed: 'Last night,' says Genest, 'Mr. Kemble performed his favourite character of Penruddock, in The Wheel of Fortune. This is one of the parts in which he appears to the highest advantage, and the performance is a complete and masterly one. ${ }^{30}$ On March I3, I 807, Kemble gave the first of twelve performances which were announced as his farewell appearance on the Edinburgh stage, prior to his final retirement. Among the rôles chosen were Cato, Macbeth, Wolsey, Coriolanus, Brutus, Hamlet-and Penruddock.

27 The European Magazine, March, 1795.

28 Genest, 7.187.

29 Biographia Dramatica, 4.400. See also Mudford, Life of Richard Cumberland, 553, Mitford, Recollections of a Literary Life, 171-2, and Cumberland, British Theatre, 18.

30 Genest, 7.187. 
The Wheel of Fortune is, in theme and tone, not unlike one of Kotzebue's plays. Mrs. Inchbald justly estimated the relations of the two in her prefatory remarks to The Wheel of Fortune: 'Never was there one play taken from another with such ingenuity, such nice art, and so little injury to either, as this play has been taken from the German "Misanthropy and Repentance;" leaving still the German to be translated into English by the title of "The Stranger."

'It is said Mr. Cumberland merely saw a critique on Kotzebue's drama in a review, some years before it was brought upon the London stage; and from thence collected substance for this most interesting play . . . It is certain he is no farther indebted to the foreign author, than for a faint glimmering of plot, incident, and character, to which he has added his own original sunshine. $A$ reader may peruse the two plays in one evening, and yet be highly delighted with both;-they are performed on succeeding nights, yet auditors go successively to the theatre; and certain spectators do not even find a resemblance between them.' ${ }^{31}$

Cumberland's response is amusing and characteristic: 'I had been better pleased if Mrs. Inchbald . . . would not have taken from me (what she does not want for herself) the credit of originality as the author of The Wheel of Fortune. I must think it was not a very ladylike action in her . . . ${ }^{32}$ It is certain that Cumberland cried out before he was struck. Mrs. Inchbald merely denied the seriousness of a resemblance which all could see. Whether Cumberland was familiar with Kotze-

31 Mrs. Inchbald, The British Theatre, 18. 'Remarks Prefatory to "The Wheel of Fortune.",

32 The London Review, conducted by Richard Cumberland, 1, 'Introductory Address,' 3. 
bue's drama or not, the plays are sufficiently dissimilar to discount the charge of plagiarism.

Cumberland was singularly fallible in judging his own plays. Mudford tells the anecdote of 'a gentleman who seized an opportunity of thanking [the author] for the delight he had experienced in reading The Wheel of Fortune' and says that Cumberland replied, with some chagrin, " "Sir, that is not the best thing I ever wrote." 's3 Many critics thought The Wheel of Fortune the dramatist's best play, and Mrs. Inchbald, though she mentioned Cumberland's debt to Kotzebue, gave the play high praise. Leslie Stephen considers The Wheel of Fortune and The Jew Cumberland's two most popular dramas. ${ }^{34}$

The success of The Wheel of Fortune was due to a simultaneous exercise of Cumberland's talents. We find many plays of his containing graceful dialogue, many with a forceful moral appeal, and a few with a single powerful character like Sheva or Don Pedro. But in The Wheel of Fortune there is a happy combination of almost all these essentials. The restrained, thoughtful diction, the exaltation of Penruddock's moral victory, and the simplicity and strength of his character, unite to create a drama of interest, and some permanent value.

33 Mudford, Life of Richard Cumberland, 556.

34 Dictionary of National Biography, 'Richard Cumberland.' 


\section{CHAPTER XIV}

\section{CUMBERLAND'S NOVELS.-BROTHER DRAMATISTS}

HE success of The Wheel of Fortune might have led
Cumberland into the final belief that what talents fate had given him were destined to be employed in the writing of sentimental comedy. Yet zeal for reputation again brought him from the paths of righteousness. The same year which gave Penruddock to the world brought forth his second novel, Henry. While The West Indian and The Wheel of Fortune were acted in England and America well into the nineteenth century, Henry sank at once into a repose which has never been disturbed; its characters, as stiff as Cumberland's theory of novel-writing, have been mercifully forgotten. The mild welcome previously accorded Arundel was the cause of this new essay. 'This,' says the author, 'determined me to write a second, on which I was resolved to bestow my utmost care and diligence.' Cumberland's model was Tom Jones, and Fielding's influence invigorates, almost creates, the novel. Most obviously imitative are the chapters prefatory to the twelve books, all written in the manner of Fielding. The reader will call these excellent mechanical imitations of the greater novelist. By negation Cumberland shows the power of Fielding; his pleading and entreating tone contrasts ill with the kindly assurance of Fielding. The chords are struck, but the master's touch is lacking. A student of the comparative influences of the eighteenth century novelists will find interest in Cumber- 
land's account of his own apostleship. The following portraits are taken from Henry. The originals are not difficult to recognize.

An eminent author [Cumberland begins] whose talent for novel-writing was unequalled and whose authority ought greatly to weigh with all who succeed him in the same line, furnished his baiting-places with such ingenious hospitality, as not only to supply his guests with the necessary remissions from fatigue, but also to recruit them with viands of a very nutritive, as well as palatable quality. According to his figure of speech, (which cannot be mistaken, as alluding to his prefatory chapters, ) he has been not only a pleasant, facetious companion by the way, but acted the part of an admirable host at every one of the inns. Alas! it was famous travelling in his days. I remember him full well, and despair of ever meeting his like again, upon that road at least.

Others there have been, and one there was, of the same day, who was a well-meaning, civil soul, and had a soft simpering kind of address, that took mightily with the ladies, whom he contrived to usher through a long, long journey, with their handkerchiefs at their eyes, weeping and wailing by the way, till he conducted them, at the close of it, either to a ravishment, or a funeral, or perhaps to a mad-house, where he left them to get off as they could. $\mathrm{He}$ was a charming man, and had a deal of custom; but the other's was the house that I frequented.

There was a third, somewhat posterior in time, not in talents, who was indeed a rough driver, and rather too severe to his cattle; but in faith, he carried us on at a merry pace over land or sea; nothing came amiss to him, for he was up to both elements, and a match for nature in every shape, character, and degree: he was not very courteous, it must be owned, for he had a capacity for higher things, and was above his business; he only wanted a little more suavity and discretion to have figured with the best. ${ }^{1}$

But 'the famous travelling' of Fielding was not for Cumberland. Henry gives no remission from fatigue.

1 Henry, Book 2. 
Henry is an infinitely correct and dull young man who, having all the experiences of a Joseph Andrews, takes them with entire seriousness. The progress of his virtue through seduction, calumny, and murder does not differ materially from many a play or novel, nor can the achieving of a father and a bride in the last of the twelve books cause an overwhelming shock of surprise. The character of Ezekiel Daw, the Methodist preacher, is touched with happy strokes, and received hearty praise from Scott, who says: "We are of opinion that the character of Ezekiel Daw, which shews the Methodist preacher in his strength and in his weakness, bold and fervent when in discharge of his mission, simple, well-meaning, and even absurd, in the ordinary affairs of life, is not only an exquisite, but a just portrait.' ${ }^{2}$ The other characters, Zachary and Jemima Cawdle, Susan May, and Fanny Claypole may be set down as vulgar caricatures. Lacking the refinement in which Cumberland often clothes his characters, they fall to the other extreme of commonness, without the redeeming graces of heartiness and health. The charges of coarseness laid upon Henry are well substantiated by a reading of the novel.

The hopelessness of Cumberland's style as a novelist is more striking than weakness of either his plot or his characters. Interminable speeches dry up our patience, and the singsong balance of pedantic sentences from the lips of heiress and maid creates a constant air of unreality. No one except Cumberland himself may call it 'a simple, clear, harmonious style.'

While writing Henry, Cumberland evolved an elaborate theory for the composition of novels, a short outline of which is given in the Memoirs. The tone of com-

2 Novels of Srift, Bage and Cumberland, 'Prefatory Memoir to Cumberland,' 55 . 
placency is singularly incommensurate with the success of the novels. 'If,' he says, 'the readers of Henry have agreed with me in the principles laid down ... I flatter myself they found a novel conducted throughout upon those very principles, and which in no one instance does a violence to nature, or resorts to forced and improbable expedients to excite surprise. . . .'

In all the prose writings of Cumberland we may discover the dramatic point of view. The Observer contains a sentimental comedy; the characters of Arundel would form an admirable dramatis personae; in Henry is an illumining statement of the dramatic theory applied to the novel. 'A novel,' he says, 'may be considered as a dilated comedy; its plot, therefore, should be uniform, and its narrative unbroken: episode and digression are sparingly, if at all, admitted; the early practice of weaving story within story should be avoided; the adventures of the Man of the Hill, in The Foundling, is an excrescence that offends against the grace and symmetry of the plot: whatever makes a pause in the main business, and keeps the chief characters too long out of sight, must be a defect. In all histories, whether true or fictitious, the author cannot too carefully refrain from speaking in his own person; and this is yet another reason to be added to those already given, why political discussions should never be admitted in a novel. . . .'s

It is the strict adherence of Cumberland to this plan and the lack of inspiration which make Henry excellent as an instance of theoretical writing, but worthless as a readable novel. 'To us,' says The Edinburgh Review for November, I8.14, 'it appears that a story may possess novelty, probability, and variety in its incidents; that the

3 Henry, Book 6. 
incidents may be arranged by the narrator, so as to keep us ignorant of the final issue till the last; that it may possess all the ornaments which our author has enumerated-a good style, characters well defined and interesting in themselves, sentiments as sublime as any in Epictetus, and descriptions as fine as in the Romance of the Forest, or as correct as in Bell's Travels; nay, to crown all, we can even conceive that the story shall be written in prose;-and yet, that with all these merits, which are all that our author requires, it shall be a string of events so unimportant or unimpassioned, that a second perusal would be quite insufferable. Have we not seen $\mathrm{Mr}$. Cumberland's novels?'

Cumberland has some uneasy defences of the dubious passages in Henry: 'What I have written,' he says, 'I have written in the hope of recommending virtue by the fiction of a virtuous character, which, to render amiable, I made natural, and to render natural, I made subject to temptations, though resolute in withstanding them.' ${ }^{*}$ The Memoirs contains a similar passage: "If in my zeal to exhibit virtue triumphant over the most tempting allurements, I have painted those allurements in too vivid colours, I am sorry, and ask pardon of all those, who thought the moral did not heal the mischief.' ${ }^{5}$ It cannot but be surprising that the writer who sought to elevate the stage and who stood for morality and benevolence should have indulged in certain scenes found in Arundel and Henry. Mr. Hitchman frankly calls them indecent, and says it is a plain evidence of failing powers. ' $\mathrm{Mr}$. Cumberland,' says a reviewer, '. . . has, in his story of Arundel, already made a very successful display of his inventive talents. But we are now to announce a work,

4 Henry, Book 10.

${ }^{5}$ Memoirs, 261-2. 
acknowledged to be the production of his pen, which, if we mistake not, will raise his literary reputation higher than any of his former pieces. . . . Within a small circuit of rural scenery, Mr. C. has brought together a group of characters, diversified by rank and profession, and contrasted in habits and manners, and relates concerning them a tale equally remote from insipidity and improbability. . . Henry, the hero of the tale, possesses a delicacy of honour, a firmness of virtue, and a generosity of sentiment, above the ordinary standard. . . . In short, as a lively picture of manners, and an interesting representation of familiar life, which is written in an easy flowing style, without any affected novelty in phrase or arrangement, and in which, though natural passions are described without a squeamish regard to false delicacy, the general tendency and effect is strongly to impress the mind of the reader with the love of virtue, this novel may be pronounced a master-piece. ${ }^{\prime 6}$

Cumberland was sixty-three years old when he wrote The Wheel of Fortune. His position in literature and the world was now clearly established. The dreams of boyhood were not fulfilled; nor could they ever be. Neither were the aspirations awakened by The West Indian as near realization as a quarter of a century before. But The Jew and The Wheel of Fortune emphasized more vigorously than ever where lay his one talent. $\mathrm{He}$ was a successful writer of sentimental comedy-nothing more. The prints of the time record his status, not illustrious, but honourable. We find him generally recognized as 'dramatic writer-in-ordinary to the theatre.' A jealous rival complains because 'he seems to have got possession of the town' and Mrs. Thrale, in a letter to

${ }^{6}$ The Analytical Revierw, May, 1795. 
the Reverend Daniel Lysius, links him with the inevitable Jephson as a regular provider for the stage. On June 9, I795, Doctor Burney confesses his admiration for Cumberland's 'three successful plays in one season." influence at the theatres is not to be despised, and there are stories of his friendliness to dramatic writers less fortunate than himself. If his jealousy of Fanny Burney had been real, it did not check his willingness to render her a generous service. Sixteen years later he offered to help her with a play. On March 2I, I795, at Drury Lane Theatre was performed a tragedy by Miss Burney, Edwy and Elvina. Despite the acting of Mrs. Siddons and Kemble, the play failed, and was at once withdrawn. 'Mr. Cumberland,' Doctor Burney writes his daughter, '. . . was extremely courteous, and seemingly friendly about you and your piece ... He expressed his sorrow at what had happened at Drury Lane, and said that, if he had had the honour of knowing you sufficiently, he would have told you d'avance what would happen, by what he had heard behind the scenes. The players seem to have given the play an ill name. But, he says, if you would go to work again, by reforming this, or work with your best powers at a new plan, and would submit it to his inspection, he would, from the experience he has had, risk his life on its success. This conversation I thought too curious not to be mentioned.'s Fanny wrote in reply: 'Your conversation with $\mathrm{Mr}$. Cumberland astonished me. I certainly think his experience of stage effect, and his

'Diary and Letters of Madame D'Arblay, Dobson ed., 5.260. Cumberland as a successful playwright was satirized in a pasquinade, The Rutland Volunteers Influez'd [sic], which appeared in 1783; likewise in the couplet:

Let Cumberland produce a play,

And Keate to Andrews yield the day.

s Ibid., 5.252-3. 
interest with players, so important, as almost instantly to wish putting his sincerity to the proof.'

In the meantime Cumberland produces plays overnight with a speed which his contemporaries could endure with difficulty. A criticism by Arthur Murphy, long a rival of Cumberland's, is typical of the malicious nonsense that the dramatist had to bear:

Richard Cumberland, Esq. (is) a gentleman, who had been for some years hovering about the skirts of Parnassus, without entering far enough to taste the Pierian spring, and without gaining a sprig of laurel. At length, it seems, he penetrated the green retreats, exclaiming with fervent zeal and ardour, as he approached the laurel-grove, that he should be happy if he could grasp the golden branch. . . . Thalia lent a favourable ear, and directed him on his way. He seized the prize with avidity; sensations unfelt before raised him above himself, and new ideas crowded on his imagination. He surveyed the mass of life, and having selected his dramatis personae, arranged the plan of a comedy. . . .

$\mathrm{He}$ should, however, have remembered, that, when he had plucked one golden branch, another grows in the room of it. . . . This, though told by Virgil, he seems to have forgot. Flushed with success, prolific, eager, and too rapid, he hurried on without the smallest regard for fame. Festina Lente ought to have been the rule of a man who had given proof of real genius. But to bridle-in his struggling muse would to him be too much restraint. ${ }^{10}$

'The struggling Muse' produced nine more pieces between 1795 and I 800 , all totally lacking in originality or distinction. It was, indeed, said that Thomas Davies had in mind our author when he spoke of the well-known dramatic writer who "lived upon potted stories, and said that he made his way as Hannibal did, by vinegar; having begun by attacking people; particularly the players.' ${ }^{11}$

${ }^{9}$ Diary and Letters of Madame D'Arblay, Dobson ed., 5.257.

${ }^{10}$ Life of David Garrick, 2.87-9.

11 Boswell, Life of Johnson, Hill ed., 3.40. 
First Love, a light comedy of sentimental intrigue, was acted at Drury Lane Theatre on May 12, I 795. 'The general moral is clear,' says The European Magazine for June, that 'parents should never cross the dictates of a first love, as it is the genuine effusion of innocence and simplicity, and promises more than any other circumstance to secure conjugal felicity-' The Dependant, performed at the same theatre on October 20, I 795, lasted one evening. It was then the custom on the first night to try the temper of the audience in respect to other performances. When Bannister Junior stepped forward, at the conclusion of The Dependant, to announce the play for a second representation, his intention, says The London Chronicle of October 2I, 'was frustrated by the clamour of disapprobation.' 'Mr. Cumberland,' says Boaden in satiric vein, 'had done recently so much, that I suppose five weeks were as long a period as he allowed to the composition of a comedy-On the 29th of this month he occupied Drury Lane stage with a thing called The Dependant. It was not suffered to linger in its uneasy station, but was brushed away on the first night. ${ }^{12}$

A reader of the plays of this period of Cumberland's career cannot but sympathize with James Macpherson, who, in lamenting his lack of leisure, says: 'As Diogenes said, when he was reading one of C . . b . r . . . d's Plays to a yawning Audience, and had come to the $5^{\text {th }}$ Act-"Courage! My friends, I see land!"-I am now so far in the $5^{\text {th }}$ Act, that, I believe, to-morrow or the next day, I may step on shore. ${ }^{, 13}$ The Days of Yore, put on at Covent Garden on January 13, I796, and Don Pedro, which appeared at The Haymarket, ${ }^{14}$ on July 23

12 Life of Mrs. Jordan, 1.290.

13 The Whitefoord Papers, Hewins ed.

14 Genest, 1.266. 
of this year failed. The former, to use Genest's phrase, 'wants incident'; the latter, according to The London Chronicle of July 27, 'was given out for a second representation with a mixture of applause and disapprobation.' Don Pedro manifests one of Cumberland's dramatic virtues, the depicting of a single powerful character. 'Don Pedro,' to quote Genest, 'is one of those hardened villains, who are not often to be met with, but the character is not pushed beyond the bounds of nature. ${ }^{15}$ His attraction is the attraction of Don Juan; he conquers by his very excess of wickedness.

On May 7, I 797, Drury Lane offered The Last of the Family. This comedy Oulton, the dramatic historian, describes as 'a discarded foundling.' ${ }^{16}$ 'The idea,' he concedes, 'afforded room for interest; but the parent who gave the unfortunate bantling birth, left him without support and his existence on the stage was consequently rendered short.' On the twenty-third of the following November False Impressions was acted at Covent Garden Theatre. 'The characters and the best of the plot of this piece,' says The European Magazine for December, 'are evidently taken from . . . HENRY,' and adds that 'the play has most of the faults of this Author's performances, and some of his merits. It is not calculated (though it has been very successful) to increase the reputation of the author of the West Indian.' False Impressions is easily the most readable of the later plays. Emily is a character of verve and charm, and Scud, who suggests a Jonsonian buffoon, energizes the entire play by his alert, brittle speeches. Eleven days after the first performance of The Last of the Family, was acted The Village Fête,

15 Genest, 7.277.

${ }^{16}$ History of the London Theatre, 1.24. 
a musical piece generally ascribed to Cumberland. The piece was performed in honour of the royal nuptials, and, was probably given but twice. During this same year Cumberland translated The Clouds. From musical comedy to Aristophanes! This play is ranked by Genest as a composition deserving of production. It may be found in The Observer, verifying the judgment of The Edinburgh Review that it is 'Aristophanes imprisoned in brocade and mounted upon stilts into the bargain. ${ }^{{ }_{17}}$ Two comedies close the necrology of this period. The Eccentric Lover appeared on April 30, I798, at Drury Lane Theatre, and was never acted again. December 5 of this year saw the production of $A W$ ord for Nature, or The Passive Husband. 'It was,' says Boaden, 'but a word. It had the slightest of all Cumberland's plots, nothing whatever of character, and the interest was never the subject of the smallest doubt through the whole five acts. ${ }^{18}$

Besides his regular dramatic productions during these years, Cumberland wrote several prologues and occasional pieces. ${ }^{19}$ When Miss Betterton first appeared at Covent Garden as Edwina in Percy, it was Cumberland who wrote the introductory address. ${ }^{20}$ On September I6,

17 The Edinburgh Review, November, 1820.

18 Memoirs of the Life of John Philip Kemble, 386.

19 The Gentleman's and Lady's Weekly Magazine for Friday, March 18,1774 , says that the prologue to Sethona, Alexander Dow's tragedy, was written by Cumberland. In Prince Hoare's comedy, Sighs, or the Daughter, 'a beautiful ballad was introduced . . . written by Mr. Cumberland.' See also The Cabinet, 1.293 and 1.355.

20 The address began:

FRIENDS of the Moral Stage, whose Smiles bestow

Those joys that cause the throbbing heart to glow;

You, whose device can panic fears controul,

And light the lamp of genius in the soul. . . .

See The European Magazine, November, 1797, and Memoirs of Mrs. Crouch, 2.300 . 
I 799, "before the comedy of "Laugh when you can," an occasional address, written by $\mathrm{Mr}$. Cumberland, was spoken by Mr. Pope; the chief subjects of which were the death of Tippoo and the decorations of the theatre. ${ }^{21}$ On October 25, I 798, Thomas Dibdin had produced The Mouth of the Nile, or The Glorious First of August. 'Previous to its representation, Mr. Dibdin having had an interview with Mr. Cumberland, . . . was advised, by this gentleman, to write the present temporary trifle. ...'22 The Dibdins and Cumberland were closely allied, professionally at least. T. Dibdin's London Theatre contains three of Cumberland's comedies. ${ }^{23}$ On November 23, I798, T. Dibdin's farce, The Jew and the Doctor, was acted. 'As there was a benevolent Jew in the piece, it was sent to Mr. Cumberland, author of the comedy of the "Jew" for any alteration he might deem proper."24 In some way C. Dibdin offended Cumberland. 'Mr. Cumberland,' says he, 'had brought out an opera at CoventGarden, which had no great success, and he afterwards cut it down to an after-piece, which was brought out at Drury-Lane. I was applied to, by the author, to compose the piece anew; but apprehensive that the transaction would savour of the article, I premised that it must be a separate charge. To this he agreed, desiring me to send him my terms, which I did in a letter. Each article was valued reasonably by his own confession; and, after the piece came out which had but little success, for it was

21 Oulton, History of the Theatres of London, 2.54.

22 Ibid., 2.41. 'Cumberland, catching at something between Cowley and Dryden, supplied a prologue, spoken with great animation by H. Johnstone.' Boaden, Memoirs of the Life of John Philip Kemble, 385.

23 These are The Brothers, The West Indian, and The Fashionable Lover.

24 Oulton, History of the Theatres of London, 2.43. 
merely an episode cut out of a first piece, I sent in my bill, which I think amounted to sixty-three pounds. I received no answer from $\mathrm{Mr}$. Cumberland; but from Garrick I got a severe reprimand, glancing at ingratitude for benefits conferred, and a peremptory notice that the piece was considered as composed under my article, consequently I got no recompense at all. These three items, as the reader will see, amount to something more than two hundred pounds; to which, if I were to ransack my memory, I might add others equal, at least, to any interest, usurious enough to have been demanded by the most rapacious Jew. ${ }^{25}$

It seems reasonably certain that Cumberland made little attempt to satisfy Dibdin, and thus secured one more enemy. That Dibdin was hostile, is clear. 'I shall not,' he says, 'notice the unhappy mode in which Mr. Cumberland's Widow of Delphi was triumphantly advertised over my head, though it was afterwards damned.' ${ }^{26}$

The clash with Dibdin was but one of many with brother dramatists. Boaden says that Cumberland 'was hurt . . on the I 8 th of the same month, of April, [ I793] by the brilliant success of Reynolds ${ }^{27}$ in his third comedy, . . . How to grow Rich. . . . The "Terence of England," forsooth! the "mender of hearts" was excessively illiberal through life; and affected to think my ingenious and pleasant friend a mere idler of the garden;

${ }^{25}$ The Professional Life of Mr. Dibdin, Written by Himself, 1.132, foot-note.

26 Ibid., 2.55. Cumberland helped to interlineate Dibdin's Touchstone.

27 From 1818 to 1822 Reynolds was 'thinker' for Covent Garden Theatre. Byron, in English Bards and Scotch Reviewers, characterizes him well:

While Reynolds vents his 'dammes, poohs, and zounds' And commonplace and common sense confounds. 
who under the awful roof of Drury, would be hooted ignominiously from the stage. ${ }^{, 28}$

Cumberland's jealousy took definite form four years later. The story, also told by Boaden, ${ }^{29}$ is best related by Reynolds himself. It was his first meeting with Cumberland, and the occasion was the performance of The Will on April I9, I 797. 'The first act received considerable applause; but, in the opening scene of the second, two or three sentences spoken by $R$. Palmer, being violently hissed, I had thereby the pleasure of being introduced to another new acquaintance, Cumberland, at that time, the established Drury Lane author. During the opposition, he rushed from the orchestra, where he was seated, to the green room, and requesting Wroughton, (then the acting manager,) to introduce him to me, the moment the ceremony was concluded, he exclaimed, with considerable irritation,

" "Let this, [sic] be a lesson to you, young gentleman!" Then taking snuff, he hastened back to the orchestra, evidently expecting that I should be benefited by further correction . . . it moved me not; as poacher on Cumberland's premises, he certainly might be excused firing one shot at me. ${ }^{30}$

'Mr. Cumberland's extraordinary behaviour to Reynolds,' says Boaden, 'was soon accounted for; he had a new comedy himself in preparation, called the Last of the Family. ${ }^{31}$

Thomas Holcroft, ${ }^{32}$ actor and dramatist, had in his 28 Life of Mrs. Jordan, 1.231.

29 Ibid., 1.323.

${ }^{30}$ Life of Frederick Reynolds, 2.141.

31 Life of Mrs. Jordan, 1.329.

32 Duplicity, the first of Holcroft's many comedies, appeared at Covent Garden in October, 1781. The Road to Ruin was acted on February 18, 1792. Holcroft won great, though not lasting, dramatic success. 
repertoire a number of Cumberland's rôles, having played with some success Colin Macleod and Mortimer in The Fashionable Lover, and in addition to these, Major O'Flaherty, Fulmer, and Varland in The West Indian. Cumberland, on the other hand, was the author of the prologue to Holcroft's most successful play, The Road to Ruin. Holcroft's diary shows us Cumberland when almost seventy years old, and tells an adventure of $T i$ berius, ${ }^{33}$ one of the dramatist's unacted plays. On October 4,1798 , he writes that Cumberland has sent this tragedy, "which had been repeatedly refused, as a new play to the theatre. It was cheerfully received till the title was read, and then immediately returned. ${ }^{{ }_{34}}$ Holcroft then describes a characteristic letter from Cumberland to Aikin, the actor, saying 'it was a mistake to suppose it the same Tiberius; it was no longer a tragedy; and if magic, music, scenery, and dialogue, could interest an audience, he had greater expectations from this than from any piece he had ever produced. It was the most laboured, the oftenest revised, and the best written of all his works. The letter concluded with an appeal to posterity. ${ }^{35}$

There are various hints that Cumberland had in him a parsimonious strain. ${ }^{38}$ George Cumberland had discovered it long ago. Writing his brother in 1777 he says : 'What if I was to ask $\mathrm{M}^{\mathrm{r}}$ Rich. Cumberland for £2O? He would never forgive me as long as I live-God bless

${ }^{33}$ This play was rejected frequently by the managers. It was finally printed after Cumberland's death. See The Posthumous Works of Richard Cumberland, 2.131.

34 Memoirs of the Late Thomas Holcroft, Written by Himself, 2.49.

35 Ibid., 2.49.

${ }^{36}$ Doctor Johnson speaks of the debts of a Mr. C- who may possibly be Cumberland. 
you both, I hope we have none of his blood in our veins. ${ }^{37}$ Likewise, Rogers suggests that he had given Cumberland financial help..$^{38}$ Perhaps, then, it is a convincing proof of Cumberland's triendship for Holcroft that he wished to lend the actor money. 'Mr. C_-, writes Holcroft, 'surprised me very much by a very liberal and friendly offer of the loan of two or three hundred pounds. ${ }^{39}$ Michael Kelly tells a story of a visit to Cumberland's home. ${ }^{40}$

In the year 1797 Cumberland invited Bannister and Kelly ${ }^{41}$ to visit him at Tunbridge Wells. His guests, having accepted, had previously arranged with Mrs. Crouch $^{42}$ to write for them, if the stay became irksome-a pleasant commentary upon their host!

Kelly's account of the first evening is diverting: 'The party consisted of myself, Bannister, Mrs. Cumberland, an agreeable well-informed old lady, and our host who, by-the-bye, during dinner, called his wife, mamma. We passed a pleasant evening enough, but wine was scarce; however what we had was excellent, and what was want-

37 Cumberland Letters, 146.

38 Clayden, Early Life of Samuel Rogers, 246.

${ }^{39}$ Memoirs of the Late Thomas Holcroft, Written by Himself, 3.107-17. 40 Ibid., 2.50-1.

41 Michael Kelly, actor, singer, and composer, after study in Italy, became musical director of Drury Lane and joint manager of King's Theatre. Kelly helped produce Cumberland's comedy, The Last of the Family, and the operetta, The Jew of Mogadore. In spite of his fondness for ridiculing the dramatist, he speaks of 'his staunch friend, Cumberland.' 'He was,' says Kelly, 'a perfect gentleman in his manners, and a good classical scholar.'

42 Miss Phillips, later Mrs. Crouch, made her first appearance at Drury Lane Theatre, in 1781, in the opera, Artaxerxes. 'She was much admired for her vocal abilities.' Her Memoirs is an amusing collection of old dramatic records, all touched with the author's sentimental point of view. Mrs. Crouch, at one time, played the rôle of Louisa Dudley in The West Indian. 
ing in beverage, was amply supplied in converse sweet, and the delights of hearing the reading a [sic] five-act comedy.' The play was too much for Kelly. 'Long before the end of the second act,' he says, 'I was fast as a church-a slight tendency to snoring, rendered this misfortune more appalling than it otherwise would have been; and the numberless kicks which I received under the table from Bannister, served only to vary, by fits and starts, the melody with which nature chose to accompany my slumbers.

'When it is recollected, that our host and reader had served Sheridan as a model for Sir Fretful, it may be supposed that he was somewhat irritated by my inexcusable surrender of myself: but no; he closed his proceedings and his manuscript at the end of the second act, and we adjourned to a rational supper upon a cold mutton bone, and dissipated in two tumblers of weak red wine and water.'

Cumberland in showing Kelly to his room remarked that the bookcase at the side of the bed 'was filled with his own writings.' The irrepressible Irishman bowed, and 'said, "I dare say, Sir, I shall sleep very soundly."

" "Ah! very good," said he; "I understand you,-a hit, Sir, a palpable hit; you mean being so close to my writings, they will act as a soporific. You are a good soul, Mr. Kelly, but a very drowsy one-God bless youyou are a kind creature, to come into the country to listen to my nonsense-buonas noches! as we say in Spaingood night! . . ." ,

Kelly admitted that 'the old gentleman was not overpleased,' but said he 'really had no intention of giving him offence. He was allowed, however, to be one of the most 
sensitive of men, when his own writings were spoken of; and moreover, reckoned envious in the highest degree.'

Kelly tells another story, well known in its day, which probably has more wit than truth. A rescuing letter having arrived from their confederate, Bannister and Kelly informed the host of their impending departure. " "My children," said he, "I regret that you must leave your old bard, but business must be attended to, and as this is the last day I am to have the pleasure of your company, when you return from your evening's rambles on the pantiles, I will give you what I call a treat."

"After dinner, Bannister and myself went to the library. "What," said I to Bannister, "can be the treat Cumberland has promised us to-night? I suppose he took notice of your saying at dinner, that your favourite meal was supper, and he intends, as we are going away to-morrow morning, to give us some little delicacies." . . . On our return from our walk, we found Cumberland in his parlour, waiting for us. As I had anticipated, the cloth was laid for supper, and in the middle of the table was a large dish with a cover on it.

'When we were seated, with appetites keen, and eyes fixed upon the mysterious dainty, our host, after some preparation, desired a servant to remove the cover, and on the dish lay another manuscript play. "There, my boys," said he, "there is the treat which I have promised you; that, Sirs, is my Tiberius, in five acts; and after we have had our sandwich and wine and water, I will read you every word of it. I am not vain, but I do think it by far the best play I ever wrote, and I think you'll say so."

'The threat itself was horrible; the Reading sauce was ill suited to the light supper, and neither poppy nor Mandragora, nor even the play of the preceding evening, 
would have been half so bad as his Tiberius; but will the reader believe that it was no joke, but all in earnest, and that he actually fulfilled his horrid promise, and read the first three acts? but seeing violent symptoms of our old complaint coming over us, he proposed that we should go to bed, and in the morning that he should treat us, before we started, by reading the fourth and fifth acts; but we saved him the trouble, for we were off before he was out of his bed. . . . ${ }^{{ }^{4} 3}$

43 Reminiscences of Michael Kelly, 280-5. 


\section{CHAPTER XV}

\section{THE VETERAN CUMBERLAND}

A BOUT r 800 Cumberland assumes the retrospective A rôle which makes his life unique. $\mathrm{He}$ is no longer living in the age of Johnson and Goldsmith; the new order is established. His are now the sorrows and also the compensations of the man who has outlived his generation. It is a melancholy picture that the Memoirs and records of the time give us, but it has pronounced interest. Goldsmith had now been dead twenty-six years, Johnson sixteen, Reynolds eight, Gibbon six, and Boswell five. New constellations had begun to shine in the literary heavens. Samuel Rogers was now thirty-seven, and William Wordsworth thirty years old. Among the great figures of the new generation which Cumberland could know, but to which he could not properly belong, were many still in the bloom of youthful genius, Scott, Coleridge, Southey, Lamb, Landor, Moore, and Jane Austen. Boyhood yet claimed Hazlitt, Byron, Shelley, Keats, and Carlyle. Many of these Cumberland was privileged to know; on some he exercised a distinct influence. We shall look at him through their eyes as we have looked at him through those of men of the eighteenth century.

The events of the last years were few and without great significance. The first eleven of the century are substantially the last of Cumberland's life. During their passage he wrote unceasingly plays, novels, and poems. Nine plays of his had first nights after 1800 . If we trust 


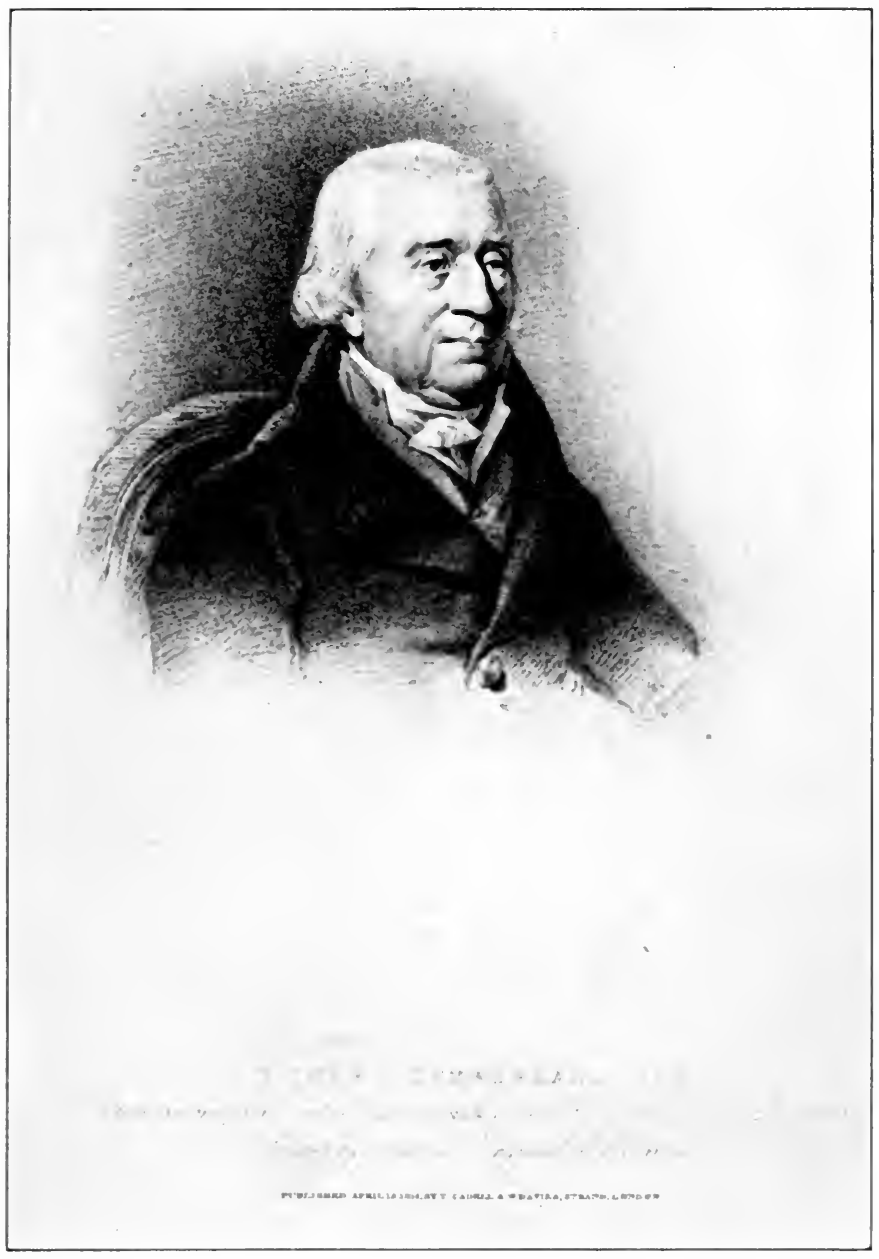



rumours, and if we number his posthumous plays, we may believe that his shelves were virtually littered with drama in manuscript. He was at work upon a tragedy when he was taken ill for the last time. Upon all these plays lie heavily the marks of weakness and anxiety. On January I6, I 80o, appeared at Covent Garden a new evidence of Cumberland's versatility in dramatic composition, Joanna of Montefaucon, 'a vehicle,' says the February Lady's Magazine, 'for the charms of music, scenery, decoration, and stage-effect.' The next three pieces were all acted at Drury Lane Theatre, Lovers' Resolutions on March 2, I 802, The Sailor's Daughter on April I 7, I 804, and 'a temporary trifle' called The Victory and Death of Lord Nelson, on November I I, I 805. Six performances of a comedy named $A$ Hint to Husbands are recorded by The Theatrical Register of The Gentleman's Magazine between March 8 and March 17 at Covent Garden Theatre. In the same season Cumberland reverted to musical comedy. On May 3, I 808 , was acted at Drury Lane Theatre The Jew of Mogadore, exploiting the adventures of 'a second Sheva,' Rooney, a stage Irishman, a British sea-captain, a Negro, and some Oudalin Arabs. The remaining plays of Cumberland written during this period may be briefly catalogued: The Robber, acted at Tunbridge Wells; The Widow's Only Son, performed at Covent Garden Theatre on June 7, 18 ro; The False Demetrius, never acted; The Sybil [sic], or The Elder Brutus, revised and acted after Cumberland's death, on December 3, 18 8 ; and three unacted dramas, Tiberius in Capreae, Torrendal, and The Confession.

Yet through letters and old diaries we have cheerful glimpses of the veteran Cumberland. He was now honoured by Sheridan's regard. Michael Kelly tells a 
story of the latter's changed attitude. After Kelly had written the music for the first act of The Jew of Mogadore the board of management at Drury Lane still hesitated to accept the piece. Meeting Sheridan one day Kelly told him of his trouble. 'He desired me,' says the composer, "to go on with it by all means; "for," said he, "if the opera should fail, you will fall with a fine classical scholar, and elegant writer, as well as a sound dramatist," (such was his impression of Cumberland's abilities). "Go, instantly," continued he, "to those discerning critics, who call themselves the 'Board of Management,' and tell them, from me, if you please, that they are all asses, to presume to sit in judgment on the writings of such a man as Cumberland; and say, farther, that I order the opera to be accepted, and put into rehearsal." ',

An excellent picture of Cumberland in these years may be had in the last pages of the Memoirs. His patriotism, so plain in the letters written to Pinckney at the time of the American Revolution, is again visible. At the beginning of the Napoleonic wars he had raised a corps for home defence. 'When,' he says, 'the volunteer infantry were dismissed at the peace of Amiens, my men requested leave to hold their arms and serve without pay. At the same time they were pleased to honour me with the present of a sword by the hands of their Serjeant Major, to the purchase of which every private had contributed, and which they rendered infinitely dear and valuable to me by engraving on the hilt of it- "That it was a tribute of their esteem for their beloved commander." ' In a letter to an unknown correspondent, written in January, I805, his pride in this company and in Britain shows forth. 'It is

1 Kelly, Reminiscences, 350. Yet Cumberland's last dramatic quarrel was with Sheridan in connection with The False Demetrius. 
true,' he says, 'that I am in the decline of life, and more deeply sunk into it than you, yet as age has not so chill'd my zeal as to prevent me from standing forward in my country's cause as Commandant of one of ye most respectable corps in West Kent, it is plain that you \& I think differently about the character of our Native Island, and that I regard her Conduct to all Nations by no means deserving of the terms you affix to it-anti-christian and unjust.' ${ }^{2}$ The martial activities at Tunbridge Wells alternated with literary patronage of ambitious litterateurs. Sheridan's conception of him as an honoured literary landmark was a popular one; age and proven ability entitled him to veneration. 'You,' he writes his friend, Sir James Bland Burges, 'have got a poet, who compliments you with his printed works, alas! I have got two unknown correspondents, who desire my judgment of their manuscript ones-the first a youth who writes Epistles in Prose; the latter a girl of seventeen who writes tragedy, as I guess, and probably neither in prose nor verse.'s

The latter part of Cumberland's life involved new literary enterprises. The year $\mathrm{I} 802$ was distinguished by a tract called $A$ few plain Reasons Why We Should Believe in Christ. 'Bred in the bosom of the church,' Cumberland had never been diverted from the paths of orthodoxy. 'I have,' he says in the Memoirs, 'rendered into English metre fifty of the psalms of David . . . upon which I flatter myself I have not in vain bestowed my best attention. I have,' he adds, 'for some years been in the

2 In the British Museum. Add. MS. 36500, f. 99. Written at 'Ramsgate, 23d Janry 1805.' Addressed to 'No. 3 Sion Hill, Clifton, near Bristol.'

${ }^{3}$ Letter (probably written to Sir James Bland Burges) in the possession of Mr. Robert Gould Shaw of Boston, Mass. Another letter in Mr. Shaw's collection, written about this time, has much to say concerning 'Killigrew's patent' and 'the popular rage agst Kemble.' 
habit of composing an appropriate prayer of thanksgiving for the last day in the year, and of supplication for the first day in the succeeding year.'

In regard to a report that he had seen Cumberland, 'the perfect man of his day,' Cardinal Newman writes: 'Lord Blashford is substantially right about Cumberland. I think he came to an evening party at our house. My Father's partial love for me led to my reciting something or other in the presence of a literary man. I wish I could think it was "Here Cumberland lies," from Goldsmith's "Retaliation," which I knew really well as a boy. The interview ended by his putting his hand on my head and saying, "Young gentleman, when you are old you can say that you have had on your head the hand of Richard Cumberland." ',

In a contemporary magazine Cumberland was described as no less than 'the able defender of Christianity, and the practical moralist of the present age,' and in The Gentleman's Magazine for December, 1815, is praised his devotion to the Bible. The new tract, since it was deemed capable of refuting all heterodox beliefs, was sent to the Bishop of London and to the Archbishop of Canterbury. No acknowledgments were received from the divines, although The Gentleman's Magazine for July, in reviewing it at length, said that Mr. Cumberland's cause was 'good and his support of it judicious.'

There is reason to believe that Cumberland was not insensible of his sound position in letters as 'the elegant Cumberland,' for forty years a contributor to the English stage, renowned for his moral influence upon literature. With perhaps a just belief in the value of a long and wellspent life, he had resolved to give the world an account

4 See Letters and Correspondence of John Henry Nequman, Mozley ed., 1.15 . 
of it. A letter written to his cousin, George Cumberland, on February 6, I 799, had told of the preparation of memoirs 'to be given to ye world, when I have left it.' ${ }^{5} \mathrm{He}$ further states his purpose in no uncertain terms: 'As no dramatic writer of this nation ever wrote so much, and few of any description so variously, I thought it justice to myself and posterity to leave this account behind me faithfully executed.' Little reflection is needed to perceive the exaggeration of the first statement, but its insertion in a personal communication indicates the writer's own conception of his prestige. Another epistle, addressed to George Lackington, the publisher, is replete with directions, and evinces the careful preparation of the author. 'At the close of the year I 804,' he begins in the Memoirs, with some inaccuracy, as the dates of the above-mentioned letters show, 'whilst I am still in possession of my faculties, though full of years, I sit down to give a history of my life and writings. I do not undertake the task lightly and without deliberation, for I have weighed the difficulties and am prepared to meet them.' So began the book which more than any other work of Cumberland's has withstood the passage of the years.

His efforts for immortality through play, novel, and epic poem were in vain. The West Indian and The Fashionable Lover are read only by students of the drama. Henry and Calvary are as nearly forgotten as inspirationless books may be, and The Observer is but a plunder chest for scholars. By a curious trick of fate Cumberland's strongest hold upon fame is by a book which he wrote to cheat poverty. 'The copy-right of these Memoirs,' wrote Cumberland, 'produced to me the sum of five hundred pounds. . . .' It produced also the far-off

${ }^{5}$ In the British Museum. Add. MS. 36498, f. 278. 
interest of perpetuating his name. Cumberland's $\mathrm{Mem}$ oirs has been a valuable source for reconstruction of the past, and, besides, a book for the quiet evening.

It was intended that the book be published after the author's death. It was finally given to the world early in 1806 . On February 19 of the same year was added a copious Supplement, as a result, doubtless, of the attacks of the Edinburgh reviewers. Francis Jeffrey in The Edinburgh Review for April, I806, had been severe: 'We will pronounce no general judgment on the literary merits of Mr. Cumberland; but our opinion of them has not been raised by the perusal of these "Memoirs." There is no depth of thought, nor dignity of sentiment about him, he is too frisky for an old man, and too gossiping for an historian. His style is too negligent even for the most familiar composition; and though he has proved himself, upon other occasions, to be a great master of good English, he has admitted a number of phrases into this work, which, we are inclined to think, would scarcely pass current even in conversation. . . . Upon the whole, this volume is not the work of an ordinary writer; and we should probably have been more indulgent to its faults, if the excellence of some of the author's former productions had not sent us to its perusal with expectations perhaps somewhat extravagant.'

The other reviewers were more charitable: 'He who can read it without interest,' said The British Critic, 'must be cast in the same mould with Sterne's morose traveller, who goes from Dan to Beersheba, and exclaims that all is barren. Allow him his partialities, allow him even a share of vanity, yet, after all deductions to be made on these scores, there will remain a narrative, which none but a man of genius could have written, and none but an illib- 
eral reader will decry. ${ }^{6}$ The review ends with a wish for Cumberland's prosperity.

Similarly, The Anti-Jacobin Review finds the book 'a modest and manly performance, replete with original and important information, ingenious disquisition, and interesting anecdote. Such indeed as we were led to expect from the character of this celebrated writer, whose qualifications and connections were peculiarly favourable to such an undertaking.

' $F$ ew men of equal genius, taste and literary assiduity, have moved in a sphere so eminent as the author of these Memoirs; he has, during a long and laborious life, cultivated and preserved an intimacy with characters the most illustrious, both for talent and station; and his early advantages were peculiarly auspicious. ${ }^{\top}$

The faults of the Memoirs are innumerable. The book violates every known canon of unity, sequence, and accuracy. Its tone is often a compound of anxious modesty and open vanity, and, in addition, the Memoirs is frequently untruthful. But its weakness is its strength. We hear the old man talking of the past-one who has spanned almost a century. The charm of the Memoirs lies in the fact that it is personal. ${ }^{8}$ What if the writer be Sir Fretful Plagiary ?

A more hallowed, perhaps, but a less fortunate venture was undertaken shortly afterwards with Sir James Bland Burges, the faithful friend of Cumberland in these years. Burges, distinguished as a lawyer and member of parlia-

- The British Critic, May, 1806.

7 The Anti-Jacobin Review, March, 1806.

${ }^{8}$ See Birrell, Men, Women, and Books, 'Richard Cumberland,'Aikin's Annual Review for 1805, Mudford, Life of Cumberland, 181, Smith, Comic Miscellanies, 2.4, and Letters of Anne Seward, 6.309.

9 Mudford's Life of Richard Cumberland, based upon the Memoirs, appeared in 1812. See Bibliography. 
ment, had been a pupil of Sir Walter Scott's, and was the author of an epic poem, Richard Coeur de Lion. He had written the prologue to $A$ Hint to Husbands, and was later associated with Cumberland in the publication of the magazine, Pic-Nic. It was he who unhappily suggested to Cumberland the writing, in collaboration, of an epical history of the Israelites' release from bondage. In $1807-$ I 808 was published The Exodiad, which, Horace Smith said, not even the unction of religion could embalm. John Murray's comment in a letter to Constable is conclusive: he sends his friend "two new epic poems by Southey and Cumberland, "Saul" and "The Exodiad," both taken from scripture, (may the Lord defend you and me from such things!).'10

In 1809 Cumberland engaged in perhaps his only untried literary project, the establishment of a magazine. This was named The London Review, and was edited by Cumberland himself, although he was then seventy-seven years old. Henry Crabbe Robinson's first meeting with Cumberland was in this connection: 'Tipper, ${ }^{11}$ he says, 'who estimated my talents as a writer by my reputation as a speaker, solicited me to become a collaborateur, under Cumberland, the well-known dramatist, in getting up a new Review, called the London Review, of which the distinguishing feature was to be that each writer should put his name to the article. ${ }^{12}$ It was this last terrifying clause which hindered and finally put an end to the new magazine. A letter from one of those concerned says: 'The project is tolerably mechanical, . . . each critique to be signed by its author, and the whole phalanx to be headed by that notorious veteran Richard Cumberland,

${ }^{10}$ Constable and his Literary Correspondence, 367.

$11 \mathrm{~A}$ bookseller in Fenchurch Street.

12 Diary of Henry Crabbe Robinson, 1.295. 
Esq. . . . ${ }^{\prime 13}$ So far in advance of the time was this idea of Cumberland's, and so deep an impression did it make upon literary men, that we find a letter from Walter Scott to Sharpe in regard to another venture, hinting at its folly: 'Observe carefully,' writes Scott, 'that this plan is altogether distinct from one which has been proposed by the veteran Cumberland, to which is annexed the extraordinary proposal that each contributor shall place his name before his article, a stipulation which must prove fatal to the undertaking. ${ }^{14}$

Cumberland's real object in founding The London Review was the correction of an abuse. Booksellers of all degrees had purchased the magazines, and behind the bulwark of anonymity dealt terrific blows at their opponents' publications, while they lavished praises upon their own. Cumberland purposed cleansing the literary world of this pest, and incidently defending his own head from the buffets of criticism. In his Introductory Address he says: 'It is by no means my disposition to censure indiscriminately a whole body of gentlemen, concerned in the like labours with my own, merely because they carry on their operations under casemates or by ambuscade, whilst I work in the open field; yet I am free to own I should like to see their faces, that I might have a better chance for understanding their manoeuvres: when the enemy veiled himself in a cloud, honest Ajax prayed for light. . . Every one must confess, that there is a dangerous temptation, an unmanly security, an unfair advantage in concealment: Why then should any man, who seeks not

13 Memoir and Correspondence of John Murray, 1.98.

${ }^{14}$ Letters from and to Charles Kirkpatrick Sharpe, Allerdyce ed., 1.351. 'Old Cumberland,' wrote a friend to Sharpe, 'volunteered to introduce my "Burletta" upon the stage; but he is a crafty Judas I count.' Ibid., 1.429 . 
to injure but to benefit his contemporaries resort to it? . . A piece of crape may be a convenient mask for a highwayman; but a man, that goes upon an honest errand, does not want it and will disdain to wear it. ${ }^{15}$

The conclusion of the Address has a dash of righteous defiance: 'Approved of by my associates as the conductor of a work, that professes the defence of genius, I trust that I possess a spirit, which neither public wrongs nor private sufferings have been able to subdue; and, though with one foot in the grave, I will do my duty and maintain my post to the last.' ${ }^{16}$

However noble Cumberland's purpose, the ambuscaders won, for The London Review was published but twice. Its death was probably due, as Moore said, to 'original dulness. ${ }^{17}$ The two Smiths, ${ }^{18}$ Horace Twiss, G. W. Crowe, or even Mr. Pye were not names to chide the genius of The Quarterly or The Edinburgh Review into silence.

The sixth essay of The London Review's first issue was an account by Cumberland of the Plan of an Epic Poem, in Twelve Books, to be entitled, Armageddon, by Mr. George Townsend. ${ }^{19}$ For Townsend, Cumberland was as enthusiastic as for all his protégés. Townsend's ambitious flight moved Byron to write: 'If Mr. Townsend succeeds in his undertaking, as there is reason to hope, how much will the world be indebted to Mr. Cum-

15 The London Review, 1, 'Introductory Address,' 2.

16 Ibid., 1, 'Introductory Address,' 6.

17 Works of Lord Byron, Moore ed., 9.62, foot-note.

18 The table of contents included $A$ new System of Domestic Cookery, formed upon principles of Economy. . . . Mr. J. Smith. Cumberland polished this essay with several quotations from the Greek.

19 George Townsend, author of various religious and polemical works. Help given him by Cumberland enabled him to enter Trinity College, Cambridge. 
berland for bringing him before the public! But, till that eventful day arrives, it may be doubted whether the premature display of his plan .. . rather incurred the hazard of injuring Mr. Townsend's future prospects. Mr. Cumberland (whose talents I shall not depreciate by the humble tribute of my praise) and Townsend must not suppose me actuated by unworthy motives in this suggestion. ${ }^{20}$ Moore says that all of Byron's anticipations were realized. In I8 5 Townsend himself said: "In the benevolence of his heart, Mr. Cumberland, bestowed praise on me, certainly too abundantly and prematurely. ...." ${ }_{21}$

In I 809 was written and published Cumberland's third and last novel, John De Lancaster. This was plainly created at the demand of poverty. The story is interrupted frequently by pathetic digressions upon the sufferings of its author, and by appeals to the reader for tolerance. The first volume ends mournfully in the following fashion: 'I have been too long acquainted with you, dear candid readers, to trouble you with any compliments, or solicit you for any favours. I have only to say, that I am doing my utmost to amuse you, and if you lay down this volume with any appetite for the second, I hope you will not find that my exertions ilag. ${ }^{22}$

The novel tells a peaceful tale of the unexceptionable families of the De Lancasters of Kray Castle, the Morgans of Glen-Morgan, and the Ap-Owens. Three generations of the first family are shown us, the eccentric

${ }^{20}$ Works of Lord Byron, Moore ed., 9.62-3, foot-note. Cumberland receives mention in English Bards and Scotch Reviewers:

Awake, GEORGE COLMAN! CUMBERLAND, awake!

Ring the alarum bell! let folly quake!

21 Ibid., 9.63, foot-note.

22 John De Lancaster, Vol. I, Chapter 7. 
iniscences of Cumberland: 'He had a vast memory, and a great facility of feeble verbiage; but his vanity, his self conceit, and his supercilious airs offended everybody. ${ }^{28}$

John Taylor, ${ }^{29}$ likewise, found Cumberland 'both disagreeable and pleasing. When he was not touched with jealousy of other writers, his manners were highly gratifying. He was full of anecdotes, but sometimes his memory failed, and little reliance could be placed on the accuracy of his narrations. He had a great command of language, and has left full evidence of his having been a good scholar, as well as a sagacious critic. ${ }^{130}$

When Hannah More's novel, Coelebs, ${ }^{31}$ was published, The London Review commented upon it, and after an unpropitious allusion to the 'hell-broth' of Macbeth, ended in the following strain: 'It indicates a wish, on the part of the author, to arrogate for the Methodists every virtue, at the expence of the rest of the community. Until it be thought necessary, however, to reform the present establishment, and until all our bishops shall be sufficiently enlightened and conversant with the doctrines of Methodism to be fit to become its apostles, it will be a duty incumbent on all those, who have the welfare and happiness of their country at heart, to watch such attempts as the present, and endeavour to repel them. The attack is more dangerous as being of so insidious a nature; it works by mine and sap. . . . COELEBS is in my hands: my duty is to say-Caveat emptor. ${ }^{32}$

Hannah More's rage was intense and forceful. She

29 John Taylor knew, at the Turk's Head Coffee-House, all the literary men of his day. He was the author of numerous prologues, epilogues, and addresses for the stage.

${ }^{30}$ Records of My Life, 2.161.

31 Coelebs in Search of a Wife appeared in December, 1809. Eleven editions were sold in England and thirty in America.

32 The London Review, 1.444. 
wrote to William Gray of York: 'I have never written, and by the grace of God, I never will write a line in my own vindication, though $\mathrm{Mr}$. Cumberland in his last Review talks of my "suckling babes of grace," and "making hell-broth;" advises the Bishop against a book which is intended to overturn the Church; that the deepest mischiefs lurk in every page of "Coelebs;" and as the book is in every body's hands, he feels it his duty to say, "Caveat Emptor." My dear Sir, shall I not pity the poor man on the borders of fourscore, who could write such a criticism after having written a poem called "Calvary"? Alas! for poor human nature, that he has not forgiven, at the end of thirty years, that in my gay and youthful days a tragedy ${ }^{33}$ of mine was preferred to one of his which perhaps better deserved success. ${ }^{34}$

Still angry two months later, Mrs. More wrote Sir William Pepys: : ${ }^{35}$ My early foe — has kept alive all that rancour which he exerted against me thirty years ago, because "Percy," with perhaps less merit, had more success than the "Battle of Hastings." Though I am not blind to the faults of my own book, and have always received just criticism thankfully, and adopted it uniformly, yet when "Coelebs" is accused of a design to overturn the Church, I cannot but smile; and I own I felt the sale of ten large impressions in the first six months (twelve are now gone) as a full consolation for the barbed arrows of $\mathrm{Mr}$. S- and $\mathrm{Mr}$. C- ${ }^{36}$

It is quite possible that Cumberland, with his stiff

33 Percy was acted at the Haymarket on July 6, 1780.

34 Mrs. Hannah More to William Gray, August 14, 1809. See Prior, Life of Goldsmith, 1.399, foot-note.

35 Cumberland held Sir William Pepys in high esteem. Pepys revised part of the Memoirs.

36 Memoirs of the Life and Correspondence of Mrs. Hannah More, 2.168 . 
orthodoxy, sincerely thought Coelebs immoral, rather than that he remembered the incident of Percy. ${ }^{37}$

But between Cumberland and other nineteenth century poets we find the kindliest regard. 'I am going,' Thomas Moore writes his mother, 'to dine third to Rogers and Cumberland: a good poetical step-ladder we make-the former is past forty and the latter past seventy. ${ }^{38}$ It is a natural touch to hear Cumberland say: 'It must be confessed the Muse of Mr. Moore is by no means pure, and he is a writer of love-songs much too highly coloured.' But this, Cumberland says indulgently, is not 'purposed mischief,' and adds: 'That he can write gravely, solidly and sublimely no critic, who has read his volume, ${ }^{39}$ will deny.' Moore's pleasure at this praise is apparent in a number of letters: 'Old Cumberland,' he again writes his mother, 'has devoted a page of his Memoirs in the second edition to $m e$, which pleases me more than I can tell you. What he says is so cordial, considerate, and respectful, and he holds such a high and veteran rank in literature. ${ }^{{ }^{\prime 40}}$ Moore wished a personal acknowledgment to be made to Cumberland, and wrote to Miss Godfrey: 'Have you met with old Cumberland's second edition? $\mathrm{He}$ has spoken of me in a way that I feel very grateful for, and if you ever see him I wish you would tell him so. ${ }^{, 1}$ A letter from this lady written three months later has a 37 The biographers of Hannah More think differently: 'One of two dramatists who were so tormented with envy at Hannah's success was Richard Cumberland.' Meakin, Hannah More, 106.

${ }^{38}$ Memoirs, Journal, and Correspondence of Thomas Moore, Russell ed., 1.186 .

39 A metrical translation of Anacreon done by Moore while at college and published in London in 1799.

${ }^{40}$ Memoirs, Journal, and Correspondence of Thomas Moore, Russell ed., 1.220 .

41 Ibid., 1.221. 
vivid picture of Cumberland: 'I forgot to tell you in my last that I saw Cumberland at Tunbridge, and I took an opportunity of mentioning to him how much you were obliged by the manner in which he had spoken of you in his book. So he smiled and panted, put his head on one side, and said how happy he was-that you were quite charming: "He has more talents than any of them; I was obliged to admit his faults to obtain credit for what I said of his excellences, otherwise praise would have been injudicious and useless." I asked him if Rogers had not told him, as I begged he would, how flattered you felt upon the occasion; and his answer was, "He be hanged; he never told me one word about it." ',42 Cumberland's esteem for Moore was lasting; and in I 809 Rogers wrote the poet: 'Cumberland dined with me yesterday. . . . He took up a volume of your Anacreon that was lying on the table, and spoke of you, as he always does, in the warmest terms. ${ }^{143}$

Cumberland and Rogers became devoted friends. A biographer of the latter, testifying to the friendship between them, says reminiscently: 'Yet another and still older friend, a frequent visitor at Rogers's house, was Richard Cumberland. . . . In his earlier days Rogers had seen much of Cumberland, and learned much from him. ${ }^{{ }^{\prime 3}}$ Cumberland's conversation, always unusual, was now enriched by the experience of a long life; in spite of its occasional 'sub-acidity' it was everywhere welcomed. Mr. Hewson Clarke, a partner of Cumberland's in The London Review, has left his impressions of the dramatist's powers of speech. 'He was not peculiarly distinguished for the profundity of his detailed observations or

42 Memoirs, Journal, and Correspondence of Thomas Moore, Russell ed., 8.66 .

${ }^{43}$ Clayden, Rogers and his Contemporaries, 1.75. 
the brilliancy of his occasional repartees; to warm or extended argument he had an invincible aversion, and nature had denied him the polished fluency of his friend Sir James Bland Burges. He never led the conversation of his social circle, or sustained its vigour by the animation of his influence. Yet, his casual remarks, when they were not distinguished by acuteness or brilliance, were characterized by that terse felicity of expression which constitutes the chief excellence of his Memoirs. ${ }^{44}$

It was Cumberland's habit to dine at Dilly's with Rogers and other literary friends. Here he entertained the company with stories of Johnson, Goldsmith, and their age, but especially loved to tell the anecdotes of Bentley, of his tenderness towards children, and of his regret that his own work was not creative. ${ }^{45}$

An extract from Rogers's Diary describes at length one of these dinners. Tweddell ${ }^{46}$ among other things had said if he had a new comedy he should choose to sit in the pit. " "No," said Cumberland, "sit in the green-room, and now and then take a peep between the scenes to feel the pulse of the house. If it is in a good humour, well; if not-why, take a walk!" ' 47

Cumberland still had the power of piquing his acquaintances, and this particular dinner was unfortunate. 'Parr,' says Rogers, 'was afterwards in a rage with Cumberland. "Why did Dilly ask me to meet such a scoundrel? $\mathrm{He}$ should tell me whom I am to meet next time. To tell Priestley $^{48}$ that to attack him was to attack philosophy, and when his back was turned to abuse him as a fire brand,

${ }^{44}$ Mudford, Life of Richard Cumberland, 596.

45 These stories are told in the Memoirs, 1.19-20.

${ }^{46}$ John Tweddell, the classical scholar.

47 Clayden, Early Life of Samuel Rogers, 213.

48 Joseph Priestley, the theologian, of whom Huxley said: 'He charmed away the bitterest prejudices in personal intercourse.' 
an innovator, and a disturber! Did the fellow think I should forget his words? And then to bring up his Epic poem. How could I tell it was his? I might have found fault with every line of it." " 49

These sound like genuine echoes of 'the choleric man.' Parr's wrath was still blazing when, a few days later, he met William Maltby. ${ }^{50}$ 'Only to think,' he cried, 'of $\mathrm{Mr}$. Cumberland, that he should have presumed to talk before $m e$, before me, sir, in such terms of my friend Dr. Priestley. ${ }^{51}$

Few wished more than Cumberland to be of the great, and few suffered more at their hands. His experiences with Lord Halifax and Lord North have a faint echo in an incident involving Lord Lansdowne and Lord Holland. Rogers says that these two 'having expressed a wish to be introduced to Cumberland,' the banker-poet invited all three to dine with him. 'It happened, however, that the two lords paid little or no attention to Cumberland (though he said several very good things), - scarcely speaking to him the whole time: something had occurred in the House which occupied all their thoughts and they retired to a window and discussed it. ${ }^{152}$

In spite of his foibles, Rogers found Cumberland 'a most agreeable companion, and a very entertaining converser.' It was apparently his wont to let Cumberland parade the glories of the past: 'His theatrical anecdotes,' says Rogers, 'were related with infinite spirit and humour; his description of Mrs. Siddons coming off the stage in the full flush of triumph, and walking up to the mirror to

49 Clayden, Early Life of Samuel Rogers, 213.

50 The bibliographer. In 1809 Maltby succeeded Porson as principal librarian of The London Institution.

51 Dyce, Porsoniana, 337. See Barker, Literary Anecdotes, 1.63.

52 Recollections of the Table Talk of Samuel Rogers, Dyce ed., 139. 
survey herself was admirable.' Rogers loved the outworn gossip of the stage. He records that Cumberland 'said the three finest pieces of acting he had ever witnessed were Garrick's Lear, Henderson's Falstaff, and Cooke's Iago.' ${ }^{153}$

Cumberland's patronage of Rogers and Moore was extended to James and Horace Smith. The latter in his essay, A Graybeard's Gossip about his Literary Acquaintance, ${ }^{54}$ has given an account of Cumberland's influence upon him. At the time of his meeting with the dramatist in $1805,{ }^{55}$ Smith was a clerk in a counting-house, but with thoughts flying disobediently to light literature and the drama. An admirer of Cumberland, Smith was disgusted with the worthlessness of the plays of other writers then occupying the stage. 'I sat down,' he says, 'one night, indignation being my muse, and composed a short poem, lamenting the decay of public taste, and the encouragement given to dumb shows, to the neglect of such sterling productions as the "West Indian," "The Jew," "First Love," "The Wheel of Fortune," \&c., to the author of which comedies I respectfully dedicated my effusion, and after having subscribed my name and address, forwarded it to him by the post. ${ }^{158}$

Smith on his high stool in the old counting-house had forgotten the incident, when the sequel came: 'All were busily occupied; not a sound was heard except the incessant scratching of quill pens upon coarse paper, when the door opened, and a person entered, whose appearance

${ }^{53}$ Recollections of the Table Talk of Samuel Rogers, Dyce ed., 138.

${ }^{54}$ The New.Monthly Magazine, 1847, 1.303, 515; 2.38, 137, 290, 461. These essays were printed anonymously, but were probably written by Horace Smith.

55 Beavan, James and Horace Smith, 98.

56 The New Monthly Magazine, 1847, 1.364-5. 
gave instant assurance that he belonged not to the shippers, brokers, and agents, or even to any of the higher commercial classes of the city. It was an old gentleman of distinguished appearance, whose somewhat large and profusely powdered head was flanked with cannon curls, and endorsed with a substantial pig-tail; his corbeau-coloured suit was of antique cut, and he bore a gold-headed cane. The grey brows gave a dullish expression to his eyes, the nose prominent and well-shaped, was more than usually distant from the somewhat compressed mouth, which relaxed into a smile of the blandest courtesy as he peered round the room, and said, in a voice of winning suavity- ${ }^{37}$

“"Mr. — at home?"

" "We have two of that name," replied the nearest clerk, "which of them do you want?"

"With a strange deficiency of tact which, as I afterwards discovered, formed one of his characteristics, the visitant answered-

" "I want Mr. - the poet." "5s Shame and confusion reigned in the counting-house.

When Smith had dragged Cumberland aside the latter regarded his admirer. " What!" he exclaimed, with a look of astonishment which, if not really felt, was exceedingly well feigned, "so young, and yet the writer of those beautiful verses!"

'On my owning the soft impeachment, he overwhelmed me with a profusion of embraces, compliments, and thanks, concluding with a glowing eulogism. . . . ${ }^{39}$

With this christening the friendship continued firm till

57 Sir Egerton Brydges's description of Cumberland's personal appearance is very like Smith's.

58 The New Monthly Magazine, 1847, 1.304-5.

s9 Ibid., 1.304-5. 
Cumberland's death. Smith has many reminiscences of Cumberland. The two were associated in the production of the weekly newspaper, Pic-Nic, founded in 1802 by Colonel Greville to vindicate certain theatrical entertainments, and to check slander of the aristocracy. The contributors numbered Cumberland, Sir James Bland Burges, Monsieur Peltier, Mr. Croker, ${ }^{60}$ James and Horace Smith, ${ }^{61}$ and Mr. Combe, the editor of the paper.

The board was soon torn by schisms. Colonel Greville's papers were too frivolous, Burges's were too dull, and Cumberland thought badly of both. At one of the Thursday meetings in Piccadilly, Greville discharged the corps of contributors, and announced the election of no less a person than John Wilson Croker. 'Cumberland, buttoning up his coat, preserved a sullen silence, until he had left the room, when Greville said to him,

" "Well, what think you of my new friend? He talks a good deal, I must confess, but he talks well."

" "Half of that is true," replied the dramatist, laying a malicious emphasis on the first word; after which he finished the fastening of his coat, with vehement twitches that threatened to tear off the buttons, twisted a comforter hastily round his throat, put on his broad-brimmed hat, pulled it over his eyes, and departed in dudgeon. ${ }^{62}$

Pic-Nic, though newly named The Cabinet, ceased to be in the fall of 1803 .

Another story told by Smith of Cumberland's petulance is that of his call upon the accounting firm of Boddington

${ }^{60}$ John Wilson Croker, later Secretary of the Admiralty and a distinguished writer. He says that he knew Cumberland well during the last years of the latter's life.

61 See Beavan, James and Horace Smith. See Smith, Comic Miscellanies, the poem, 'In Private Theatricals.'

62 The New Monthly Magazine, 1847, 1.516. 
and Sharpe. ${ }^{63}$ 'As his object,' Smith relates, 'was to borrow money upon a Bill of Exchange, I did not accompany him into the house, but awaited his return in Fenchurch-street, where he presently joined me, evidently in high dudgeon, buttoning up his coat with nervous irritation, and muttering between his clenched teeth, "Shabby Sharpe!"- "Stingy Sharpe!"- "Close-fisted Sharpe!" winding up his abusive epithets with the loud and vehement expectoration of the words, "Hatter Sharpe!" , 6 After Cumberland's ire had abated, Smith discovered that Sharpe, who had dared to refuse the loan, had once been a hatter!

This Cumberland considered a bitter gibe, for family pride and some attention from the great had stiffened overmuch his sense of decorum and place. Smith found that he was not 'insensible of his dignity as major-commandant of the volunteer infantry at Tunbridge Wells, of whose attachment to his person, and of the handsome sword they presented him, he loved to discourse with a sensibility that sometimes bordered upon the mawkish. ${ }^{105}$ An example of the burden of propriety which he carried occurs in a grave story connected with the duel between Captain Macnamara and Colonel Montgomery. ${ }^{66}$ "When Cumberland was told that the catastrophe had for several days alienated the senses of a Mrs. Biggin, who was understood to be attached to the colonel, he replied, "Ha! very sad, very sad! but this public association of her name with his, will not, I fear, add much to her reputation; and, besides, the world cannot be expected to sympathise too deeply with a lady who has given her name to a coffee-

\footnotetext{
${ }^{63}$ Richard Sharpe, well known as 'Conversation Sharpe.'

${ }^{64}$ The New Monthly Magazine, 1847, 1.516.

${ }^{65}$ See Memoirs, 2.334.

${ }^{68} \mathrm{~A}$ famous incident of the time.
} 
strainer." ${ }_{67}$ This last seems a bit of excellent irony, but was intended by Cumberland as a serious comment upon the sympathies of society.

Of the many hobbies of these years one was Cumberland's rage against the defrauding of authors by the booksellers. Upon this subject Cumberland, usually coolly sarcastic, always spoke vehemently. Smith depicts Cumberland's rage at a wealthy bookseller, one of the 'ruthless fellows' who 'drink out of the skulls of their best friends.'

" "But they cannot rob you of your laurels," I [Smith] remarked.

،"Oh, no!" replied my companion, bitterly ; "they allow their victim to wear a chaplet when they sacrifice him." ", 8 Cumberland went so far as to try to form an association to defeat the booksellers. Circulars were sent to leading writers, a meeting was called, but it all availed nothing.

Smith noted also Cumberland's hatred of the French which had been accumulating for three-quarters of a century. At a dinner where French cookery was served, "we were all too John Bullish,' says Smith, 'to find any thing palatable upon the table, but our most patriotic abhorrence was reserved for an unfortunate fricandeau, which, as one of the party declared, was only fit to be given to a dog. "A dog, sir," exclaimed Cumberland,

67 The New Monthly Magazine, 1847, 1.518. Cumberland's pleasure at the marriage of his daughter to Edward Bentinck was well known. A story existed of 'another whose son or daughter had also entered a noble family meeting [Cumberland] at a dinner-party, and mutually entertaining one another with inquiries about my lord and my lady and anecdotes of the same until the patience of everybody was exhausted.'-Temple Bar for June, 1879. 'Dr. Bentley's grandson,' says The Gentleman's Magazine for November, 1779 , 'is a scholar but still more desirious of being reckoned a person of fashion.'

68 Ibid., 1.520-21. 
pushing away his plate with a look of infinite disgust, "not even fit for that, unless it were a French dog!" ",

What Scott calls Cumberland's 'sub-acidity' of temper appears in an anecdote of his residence at Ramsgate. ' $\mathrm{He}$ had two sister neighbors, whose censorious tongues had rendered them rather unpopular. At some public meeting, Cumberland happened to be seated next to one of them, and, on her rising to depart, offered to put on her shawl, observing at the same time, for he rarely lost an opportunity of paying a compliment, that it was almost a sin to hide such shoulders.

" "Oh!" said the lady, with a smirk; "my sister and I, you know, are famous for the beauty of our backs."

" "Ha! that is the reason, I suppose, why your friends are always so glad to see them," sneered the dramatist, as soon as the party was out of ear-shot. ${ }^{170}$

Smith speaks of Cumberland's fondness for anecdote, ${ }^{71}$ and describes his enthusiasms for gifted young men. At one time he was begging everyone to go to the Haymarket to see $\mathrm{Rae}^{72}$ as Mortimer in The Iron Chest, ${ }^{73}$ and at another his zeal centered in Smith himself. In a gathering where Love for Love was mentioned, someone said, 'When will the days of Congreve return?' 'Cumberland,' Smith says, 'pointed to me, and exclaimed with an air of perfect conviction,-_"When that boy writes a

69 The New Monthly Magazine, 1847, 1.519.

70 Ibid., 2.42.

${ }^{71}$ Cumberland delighted particularly to tell the story of an Irishman who threw himself out of a tree for joy at beholding the Bishop of Clonfert. See Memoirs, 1.286, and, also, pages 3-4 of this book.

${ }^{72}$ Alexander Rae made his first appearance on the stage on January 28,1806 , at Bath in the rôle of Hamlet. Oxberry says he was the best Romeo he had ever seen. See Memoirs, 2.383.

${ }^{73}$ A play by George Colman, the younger, acted at Drury Lane on March 12, 1796. 
play." On that hint I wrote; what boy would have disbelieved the prophecy? My comedy met a cold reception, lingered for a few nights, was then withdrawn, and is now utterly forgotten. Humbled but not quite discouraged, I attempted a farce, which was condemned on the first night. So much for the new Congreve! '74

Cumberland's friendliness for Smith, however, was steady and of practical benefit. James and Horace were permitted to help him in his new edition of Bell's British Dramatists, and the patron cast a critical eye upon James's work upon the Latin poet, Horace. Smith tells this story of his tutelage: 'At an early period of my acquaintance with Cumberland, I had written a romance, which, in accordance with the prevalent taste, abounded in monks, monsters, horrors, thunderings, ghosts, and trap-doors. This farrago I requested him to peruse, and give me his opinion as to the propriety of its publication. He took the manuscript to Ramsgate, where he told me that his daughter, Lady Edward Bentinck, should read it to him, and in a few days it was returned to me with an unfavourable verdict, softened by compliments and many encouragements to new and better efforts. On my telling him, at our next interview, that I had immediately burnt it, he paid me the equivocal talent of saying; "You showed talent, my dear boy, in writing that work, but you have. evinced much more in committing it to the flames." ${ }_{75}$

74 The New Monthly Magazine, 1847, 2.41. One object of Cumberland's enthusiasms seems to have been Joseph Blacket, the author of a blank verse poem, remarkably titled The Dying Horse. See Blacket, in Dictionary of National Biography, and The Gentleman's Magazine, October, 1811.

75 The New Monthly Magazine, 1847, 2.42. Smith says that he retaliated for Cumberland's criticism of 'diffuseness' by quoting Cumberland's poem Pride to a friend. In this Cumberland has expanded the phrase, expende Hannibalem, into twelve lines on man's mortality. 
Smith thought the sketch of the Abbe Hussey in the Memoirs ${ }^{78}$ a better portrait of Cumberland than Sir Fretful Plagiary. Smith's final word for the dramatist has a note of sincere affection: 'Of his occasional sarcasms, proof has been afforded . . . but as his blandness and adulation were rather the result of courtly and diplomatic habits than of any intentional hypocrisy, so do I firmly believe that his bitterness-I would rather call it his malicious pleasantry-was indulged rather to point a jest than to vent any splenetic feeling; an offence only amounting to the old charge against men of wit, that they are apt to love their joke better than their friend. ${ }^{\prime} 7$

From the time of Cumberland's return from Spain his life had been clouded by poverty. In $\mathrm{I} 78 \mathrm{I}$ he had borrowed heavily from George Romney, and later from Rogers. Clayden, the biographer of Rogers, tells of Cumberland's joy at their kindness: 'Rogers had given him some pecuniary assistance, and the old dramatist, in writing his thanks, finds it difficult to moderate his gratitude. "Your bounty surprised me," he says; "I hurried back on discovering its amount, resolved for the moment to entreat you to moderate your benefaction." On second thoughts, however, he kept the money, lest his motive in returning it should be misunderstood; and he declares his uniform and unalterable esteem and love for his generous friend. ${ }^{178}$

The steady outpouring of plays between 1780 and I 8 I I was possible only to a literary mill like Cumber-

${ }^{76}$ Memoirs, 2.60. This runs in part: 'He wore upon his countenance a smile sufficiently seductive for common purposes and cursory acquaintance; his address was smooth, obsequious, studiously obliging, and at times glowingly heightened into an impassioned show of friendship and affection.'

77 The New Monthly Magazine, 1847, 2.43.

is Early Life of Samuel Rogers, 246. 
land's, but the impelling force was largely necessity. There are frequent references in the Memoirs to economy, and we may believe the cause of his activity to have been a slender exchequer. This pressure continued unrelieved until the dramatist's death.

Mrs. Cumberland had died soon after I80o. The exact date of his wife's death Cumberland does not mention, contenting himself with saying that it occurred 'some time after the death of his eldest son, who died in Tobago.' Her demise was preceded by a long and heart-rending illness. In the Memoirs there are surprisingly few references to Mrs. Cumberland; these, however, are in terms of warmest affection. There is no support for Mudford's somewhat malicious story: 'They lived happily together for many years, though I have been told, by a friend who was likely to be well informed, that his wife's love for him was sometimes displayed with too little attention to his liberty, and that her desire of having him always in her presence, especially during her last illness, amounted to a virtual prohibition of his seeing any person who did not come home to him. ${ }^{79}$

Patient under affliction as he actually was, there developed in Cumberland an undercurrent of sorrow and bitterness against the cause of his trouble. At one time he likens himself to 'the traveller who, wearied by the tediousness of the way, puts four horses to his chaise for the concluding stage. ${ }^{\prime 80}$ At another he composes for the eye of the inexorable Pitt 'a short and modest recital of [his] services and sufferings,' and prays to be recom-

79 Mudford, Life of Richard Cumberland, 130-1.

80 Memoirs, 2.304.

What on the part of candour shall be said,

But that his heart was stronger than his head?

But that advancing to a fresh attack,

He dropt, and 'died with harness on his back.' Genest, 7.191. 
mended 'for some small bounty from the crown in alleviation of [his] case.' Lastly, he quiets his distress with philosophy: 'Though I have not been at ease in my circumstances since I came from Spain, and probably never shall, I do not regret my going thither, being proudly conscious of having done my duty, and that I can look back upon no period of my past life with a clearer selfacquittal than I can on that. I am past all hope of receiving any recompense for my sacrifices, and I have accommodated myself of those privations, which the circumscription of my means prescribes. Though in my seventy-fifth year I am even now in the act of levying contributions on my brains, and thanks be to Providence, age has not quite exhausted the resource, which nature and acquirement have endowed me with.'

But there is a wearing force in prolonged sorrow or injustice, and Cumberland in extreme old age is a pathetic figure. The writing of the Memoirs-a sacrifice of pride -was another effort to ward off poverty. Biographia Dramatica recognizes his situation when it tells 'of his intention in I 809 to publish a 4 to volume of his dramas, which, we are sorry to say, because it implies a want of encouragement, has not yet appeared,' and adds: 'That a man of such learning, of such versatility of literary talent, such unquestionable genius, and such sound morality, should in the vale of years, feel the want of what he has lost by his exertions for the public good, must to every feeling mind, be a subject of keen regret.

Cumberland's necessity was common talk during the

${ }^{81}$ Biographia Dramatica, 1.158. The edition referred to, although advertised in The Gentleman's Magazine for July, 1809, did not appear during Cumberland's lifetime. In her 'Advertisement to the Reader' in the Posthumous Dramatick Works, Cumberland's daughter, Mrs. Jansen, 
last years of his life. In reviewing the Memoirs, The British Critic for May, I806, says: 'Far be from us the invidious task of endeavouring to spy out the defects, and ridicule the foibles of an author, who at seventy-two declares himself obliged to undertake the task of describing himself, for the sake of an emolument offered by a bookseller.' Two years later, in August, I8II, in a critique of Retrospection the same paper says: 'The most melancholy part of this consideration is, that these effusions [Retrospection and the Memoirs] were not, in either case voluntary. They were forced from [Cumberland] by the pressure of necessity, and a necessity, the severest part of which appears to have been brought with cruelty upon him.' A mysterious 'note' follows, suggesting the secrets of Cumberland's connections with the government which 'delicacy' forbade the reviewer to reveal: 'We dare not tell the tale, lest we should be mistaken in any of the circumstances; but, if it was as we heard it from an intimate friend of the sufferer, there must have been, somewhere, great want of feeling.'

The London Examiner of May 8, I 808, after censuring The Jerw of Mogadore, says: 'Upon the whole, the lovers of literature will always remember with respect the earlier classical taste of Mr. CUMBERLAND, but they cannot help lamenting that his pen still outlives his genius. If this tenaciousness of quill proceeds from old age, they would remind him of the continued respect but diminished pleasure of the public, and would hope that his gratitude and his good sense might at length show him the propriety

writes: 'These Dramas, which are now presented to the public, were originally intended by my late beloved Father, as a bequest to me, together with his other posthumous works; but the unfortunate circumstances, which clouded the latter years of his life, induced him to yield to the opinion of many of his friends, who had frequently urged him, to resort to the publication of them by subscription.' 
of closing his inkstand. If it proceeds from necessity, as I am much inclined to fear, it surely becomes the British Government to rescue from degradation a learned and liberal gentleman, one who has suffered in their employment, and thrown a grace upon the literature of his country.

A review of The Widow's Only Son indicates plainly Cumberland's humiliating position. Speaking of him as a writer The London Examiner of June I0, I8 Io, says: 'The more apparent, however, this truth, the more lamentable is it, that a man of genius and virtue should be reduced in his old age to expedients so mortifying,for, from what is reported in the town, and indeed from a bitter passage or two in the present drama on the miseries of writing for bread, this would actually appear to be the case. The present Administration exhibits nothing that is not altogether despicable in point of feeling as well as policy; but it is a disgrace to all the Administrations for the last twenty years, that the Author of the Observer, the West Indian, and other estimable productions, should have been thus neglected. He has contributed to adorn our literature, and we should be grateful for the honour: he has helped to encourage us in the love of virtue, and we should be grateful for the service: - he is old, and what further claim can he want upon our respect-upon our feelings - upon our very shame.'

'He is greatly changed . . . ${ }^{92}$ Rogers wrote Moore, toward the end of Cumberland's life. No one can fail to observe the difference in tone of Cumberland's last writings. His grief is plain enough in John De Lancaster, in which novel Cumberland shows us his despondency without disguise. 'I am,' he says wearily, 'ill at these

82 Memoirs, Journal, and Correspondence of Thomas Moore, Russell ed., 8.80 . 
descriptions; I confess it. Seventy years and seven, with clouds that hang upon my setting sun, will chill the brain that should devise scenes and descriptions warm with youthful love. . . . ${ }^{83}$

One cause of grief Cumberland dilates upon at some length in the Memoirs. 'Whilst I write this, my Grandson, a brave youth, of six years service in the Royal Navy, born, as I vainly hoped, to grace my name, and recompense the cares that I bestowed upon his education, lies (as 'twere before me) dead, and as yet unburied; whilst I not only mourn his loss, but feel his wrongs, of which the World must hear, if the appeal that he had made to Justice is cut short by his untimely death.' 'Where then,' he exclaims, 'can a heart-wounded man, like me, find comfort but with that beloved Daughter to whom I gave the Memoirs of my Life?' The complaint continues, and ends in a pitiable strain of weakness. After declaring that he writes these pages for the third time with his own hand, and assuring the reader of their virtue, he once more defies and implores his old enemies: 'The Criticks are most cordially welcome to every thing they can find about me as an Author. However, as I know some of them to be fair and honourable gentlemen, I hope they will recollect how often I have been useful to them in the sale of their publications, and assist me now with their good word in the circulation of De Lancaster. ${ }^{\text {' }}{ }^{8}$ Horace Smith last saw Cumberland 'altered and attenuated, his white hair hanging over his ears in thin flakes, his figure stooping, his countenance haggard. ${ }^{85}$.

83 John De Lancaster, 3.105-7.

84 Ibid., 3.105-7.

85 Poetical Works of Horace Smith and James Smith, Sargent ed., 'Biographical Memoir,' 11. See The Gentleman's Magazine for April, 1809. 
Cumberland's life was not lacking in dramatic quality, and his last days were dignified by an impressive farewell to the world in which he had lived for so many years. A very short time before his death he wrote Retrospection, a poem which 'may literally be called the last words of Cumberland,' and which glows with deep and sincere emotion:

\section{LINES}

Written by the late Mr. CUMBERLAND a short time before his Death.

World, I have known thee long, and now the hour

When I must part from thee is near at hand;

I bore thee much good will, and many a time

In thy fair promises reposed more trust

Than wiser heads and colder hearts would risque.

Some tokens of a life, not wholly pass'd

In selfish strivings or ignoble sloth,

Haply there shall be found when I am gone,

Which may dispose thy candour to discern

Some merit in my zeal, and let my works

Outlive the maker, who bequeaths them to thee;

For well I know where our perception ends

Thy praise begins, and few there be who weave

Wreaths for the Poet's brow, till he is laid

Low in his narrow dwelling with the worm.

On May 7, I 8 II, at the home of Henry Fry, to whom he had been warmly attached since his removal to Tunbridge Wells, Cumberland died. Sir James Bland Burges received the following letter:

Dear Sir,

I trust you will not deem it a liberty I take in informing you of the death of our poor friend Mr. Cumberland, who died at my 
house this morning a quarter before nine o'clock. He was taken ill last Thursday week. The day before I never knew him more cheerful or well. He was perfectly resigned and died without a groan. He was sensible, but for the last four or five hours deprived of speech.

I am, dear Sir,

Your very obedient, humble servant,

HENRY FRY. ${ }^{86}$

On May I 4 a long procession ${ }^{87}$ took its way from the home of Cumberland to the Collegiate Church of St. Peter, Westminster. Cumberland was laid in the Poets' Corner in Westminster Abbey not far from the grave of Garrick. The funeral oration was spoken by the Dean of Westminster, the school-fellow ${ }^{88}$ and life-long friend of Cumberland. 'I saw,' says Boaden, 'the venerable and tasteful Dr. Vincent . . . pronounce his affecting tribute over the grave of Cumberland. ${ }^{189}$

Good People: the person you see now deposited, is Richard Cumberland, an author of no small merit; his writings were chiefly for the stage, but of strict moral tendency; they were not without faults, but they were not gross, abounding with oaths and libidinous expressions, as I am shocked to observe is the case of many of the present day. He wrote as much as any one; few wrote better; and his work will be held in the highest estimation as long as the English language will be understood. He considered the theatre a school for moral improvement, and his remains are truly worthy of mingling with the illustrious dead which surround us. Read his prose subjects on divinity! there you will find the true Chris-

86 Letters and Correspondence of Sir James Bland Burges, 321.

87 The London Chronicle, May 16, 1811.

88 See Memoirs, 1.68-9.

89 Memoirs of the Life of John Philip Kemble, 368. 
tian Spirit of the man who trusted in our Lord and Saviour Jesus Christ: May God forgive him his sins, and at the resurrection of the just receive him into everlasting glory $!^{90}$

Cumberland had four sons. The eldest, Richard, ${ }^{91}$ married the third Earl of Buckinghamshire's daughter, Albinia, Lady of the Bedchamber to the Princess. ${ }^{92}$ Richard Cumberland died at Tobago where he had gone for employment. George Cumberland ${ }^{93}$ was killed at the siege of Charleston, on the first day that he was appointed to the command of an armed vessel. The two other sons, Charles $^{94}$ and William, ${ }^{95}$ in the navy and army, respectively, survived Cumberland.

An excellent picture of Cumberland's three daughters may be found in Fanny Burney's Diary. ${ }^{96}$ Elizabeth Cumberland, the eldest, also achieved a marriage of rank.

90 Mudford, Life of Richard Cumberland, 589-90, The European Magazine for May, 1811. As Hitchman says, this oration touched unluckily on the most vulnerable point in Cumberland's position as a moral writer. He was often attacked for a number of immoral passages in his novels, and for occasional ones in the plays. Hitchman's explanation that Dean Vincent had not read Cumberland is plausible. Hitchman, Eighteenth Century Studies, 230-1.

${ }^{91}$ See Diary and Letters of Madame D'Arblay, Dobson ed., 1.286.

92 Cumberland was proud of this marriage. He has written some fourteen stanzas upon Lady Cumberland. Memoirs, 2.96-8. Fanny Burney met the lady in 1798. 'Here I was received by Lady Rothes, who presented me to Lady Albinia Cumberland, widow of Cumberland the author's only son, and one of the ladies of the Princesses. I found her a peculiarly pleasing woman, in voice, manner, look, and behavior-' Diary and Letters of Madame D'Arblay, Dobson ed., 5.427. According to one source the marriage was disapproved of by the lady's family. Letters of Lady Louisa Stuart to Miss Louisa Clinton, Letter 121, foot-note.

93 Memoirs, $1.400,422$.

94 Ibid., 1.400, 2.294.

95 Ibid., 1.400, 2.295, 306.

${ }^{96}$ Diary and Letters of Madame D'Arblay, Dobson ed., 1.286, 287-8, 297. 
Her husband was Lord Edward Bentinck, brother to the Duke of Portland. 'The Duchess of Portland was much distressed by this marriage, but with her usual kindness and good sense sent afterwards a trunk of plain household linen to assist the commencement of Lady Edward Bentinck's housekeeping. ${ }^{97}$ The Observer was dedicated to Elizabeth Bentinck.

Sophia, the second daughter, receives scant notice in the Memoirs, as does her husband, William Badcock. ${ }^{98}$

Cumberland's youngest daughter, Frances Marianne, was born in Spain. Cumberland dedicated the Memoirs to her, and enjoined her to publish his posthumous works. His fortune, which amounted to less than $£ 450$, was left to her.

Of Cumberland's nineteen grandchildren, Richard Francis Cumberland attained the greatest distinction, becoming aide-de-camp to the Duke of Wellington.

Cumberland's death made little noise in the world. 'May 7. At Mr. Henry Fry's in Bedford-place, Russellsquare in 8oth year, Richard Cumberland, esq. a character of long and very distinguished celebrity in the republick of letters,' so runs the record of The Gentleman's Magazine for June, I $8 \mathrm{II}$, and The London Chronicle of May 9 regrets the loss of 'a profound scholar as well as an able writer in various departments of literature and a poet of no inferior class. . . . He might altogether be considered as a distinguished ornament of British literature. . . .99 This was not fame, nor have the years

${ }^{97}$ Life and Correspondence of Mrs. Delaney, Llanover ed., 6.124, foot-note. One of Romney's best-known paintings is of Elizabeth Cumberland. Chamberlain, George Romney, 304.

98 Memoirs, 2.339. Mudford, Life of Richard Cumberland, 596.

${ }^{99}$ Other accounts of Cumberland written early in the nineteenth century may be found in The Literary Panorama, 9.1070, 10.1249, 11.517, The Anti-Jacobin Review for January, 1815, The Gentleman's Magazine 
brought it. Verse, novels, essays, and plays,-all have perished, and Richard Cumberland lives only in the few master strokes of a malicious pen. What the talent and industry of Cumberland could not effect in fifty years of effort, the careless genius of Sheridan won for him in a few hours. Sir Fretful Plagiary! Who that has seen, can forget him? And the portrait is, superficially at least, just. Cumberland's enemies were right. His was a nature tortured by the smaller passions of mankind, and worry, egotism, and envy had taken strong root in his soul. But Sir Fretful is, at best, a half-truth, and, in ending, the friends of Cumberland should be heard. 'That,' says James Smith, 'he was capable of a sincere, firm and disinterested friendship I can testify; and for my own part, whether I contemplate Richard Cumberland as a scholar and an eminent man of letters, as a gentleman, and as a friend whose good offices were unremitted from the time of our first acquaintance until the day of his death, I can never recall his name without a feeling of almost filial regard and reverence. ${ }^{100}$

for June, 1811, and October, 1811, Blackwood's Magazine for February, 1826, William Beloc, The Sexagenarian, 222.

100 The New Monthly Magazine, 1847, 2.43. 


\section{CHAPTER XVI}

\section{CUMBERLAND'S DRAMAS}

I $\mathrm{T}$ is not enough to depict Cumberland's personality. 1 His worth, both for his own time and for posterity, must rest upon his dramatic achievement. His plays were constantly acted during the last quarter of the eighteenth century, and many found a place on the stage well into the nineteenth century.

Cumberland in his Memoirs [1807] indexes no less than thirty-eight dramatic pieces written by himself. To this list must obviously be added his subsequent productions, from $1806^{1}$ to $18 \mathrm{II}$. Genest says that Cumberland wrote 'about 35 regular Plays, 4 Operas, and I Farce $^{2}$ besides the alterations, making a total of fortythree dramatic productions. Biographia Dramatica credits Cumberland with dramatic compositions of various kinds to the number of fifty-four. No one of these catalogues is complete or exact, and later historians of the drama, owing to the unknown number of unacted plays, have been content to quote or approximate these lists. ${ }^{3}$

1 The first, and unindexed, edition of the Memoirs appeared in 1806.

2 Genest, 8.397.

${ }^{3}$ Ward, in The Encyclopedia Britannica, in numbering the plays relies apparently upon Biographia Dramatica, for he says that Cumberland's plays 'have been computed to amount to fifty-four.' Leslie Stephen, in The Dictionary of National Biography, quotes figures from the same work, though accusing it of inaccuracies. An excellent analysis of sentimental comedy may be found in two essays by Mr. Osborn Waterhouse, published in Anglia, Vol. 30. 
Several plays listed separately in Biographia Dramatica may be more justly regarded as revisions of earlier works. Thus The Summer's Tale, and the two plays called Amelia form one dramatic piece; The Arab is essentially the Alcanor of the posthumous works; The School for Widows is but a revived form of The Country Attorney; and $A$ Word for Nature appears fourteen years later as The Passive Husband. Thus the list in Biographia Dramatica may be reduced to forty-nine distinctly different plays. To these may be added certainly one posthumous play omitted in Biographia Dramatica, The Confession, which is included in the edition of Cumberland's plays.

It is possible to give, then, the stage history of fifty plays written by Richard Cumberland, with indications of alterations or changed titles. Of these plays, twelve were printed in a volume called the Posthumous Dramatick Works of Richard Cumberland, viz., The Sybil, or the Elder Brutus, The Walloons, The Confession, The Passive Husband, Torrendal, Lovers' Resolutions, Alcanor, The Eccentric Lover, Tiberius in Capreae, The Last of the Family, Don Pedro, and The False Demetrius."

Thirteen plays, among the weakest written by Cumberland, were, in all likelihood, never printed, ${ }^{5}$ namely, The Princess of Parma, The Election, The Bondman, The Duke of Milan, The Widow of Delphi, The Country Attorney, The Occasional Prelude, The Armourer, The Dependant, The Village Fête, The Victory and Death of Lord Nelson, The Robber, and The Widow's Only Son. The following plays were never acted: The

4 This play is mentioned by Ward in The Encyclopedia Britannica.

5 Only the songs of The Widow of Delphi were printed. 
Banishment of Cicero, The Clouds, The False Demetrius, ${ }^{6}$ Tiberius in Capreae, Torrendal, and The Confession.

Besides these fifty plays, there may be attributed to Cumberland, upon more or less certain authority, three other dramatic pieces. ${ }^{7}$ These three plays are: I. The Elders, ${ }^{8}$ which was acted during October, I 778, at Kelmarsh, Northamptonshire. The Elders was a farce performed in private theatricals. It is doubtfully assigned to Cumberland by The Thespian Dictionary. 2. The Days of Geri. This play is included in a list of Cumberland's dramatic pieces by Walter Scott. ${ }^{9}$ It is seemingly not mentioned either by Genest, by Ward in The Encyclopedia Britannica, or by Biographia Dramatica. 3. Palamon and Arcite. A manuscript copy of this play, said to be in the handwriting of Cumberland, is in the British Museum. ${ }^{10}$ No mention of the play is apparently made by Genest, by Ward in The Encyclopedia Britannica, or by Biographia Dramatica.

If we consider fifty plays as certainly Cumberland's, twenty-six may be regarded as comedies of the sentimental type, nine as tragedies, seven as operas or musical enter-

${ }^{6}$ The acting of this piece was prevented by an altercation between Cumberland and Sheridan.

7 The addition of the separately titled plays, with the three others tentatively assigned, brings Cumberland's total number of dramatic pieces to fifty-eight.

8 The Elders, of uncertain authorship, was performed at Covent Garden Theatre on April 21, 1780, and acted four times. See Genest, 6.149-50. Biographia Dramatica attributes, with some doubt, the farce to Henry Man. Whether or not this is Cumberland's piece is uncertain.

${ }^{9}$ Novels of Swift, Bage and Cumberland, 'Prefatory Memoir to Richard Cumberland,' 59-60.

10 This play was presented to the British Museum in 1864, by Mr. Coventry Patmore. Add. MS. 25990. 
tainments, five as alterations or adaptations, and three as occasional pieces. ${ }^{11}$

Cumberland boasts in his Memoirs that he was the writer of a 'list of dramas, such as I presume no English author has yet equalled in point of number.' This presumption, which neglects, for example, so prolific a dramatist as Thomas Heywood, is, in point of fact, unsound, yet it is suggestive. Cumberland's plays succeeded each other with amazing swiftness. Hardly a year between I 765 and I 8 I I passed without some new dramatic effort. He essayed all forms of drama-comedy, tragedy, opera, and interlude-indiscriminately.

Though no definite periods can be assigned in which Cumberland adopted particular dramatic forms, for convenience his dramatic activity may be divided into five periods of weakness or strength.

Cumberland's first play was written in 1761 , a classical tragedy. After a period of dramatic weakness in the field of musical comedy, he passed directly into what may be called a first period of power. Between I 769-I 77 I he wrote The Brothers, The West Indian, and The Fashionable Lover, plays whose marked success immediately established him as a leader in sentimental drama. At the end of a decade Cumberland had achieved a success which he was unable to equal in the remaining forty years of his life.

The Note of Hand was the last play of Cumberland's staged by Garrick. The dramatist turned again to tragedy and musical comedy, beginning a second period of dramatic weakness. Before the departure for Spain in 1780 , appeared, besides several adaptations, The Battle of Hastings, Calypso, and The Widow of Delphi.

${ }^{11}$ Cumberland's boyish production in 1744 of Shakespear in the Shades has not been deemed worthy of discussion. See Memoirs, 1.56-64. 
Of the half-dozen pieces between I78I and I794 should be mentioned only The Walloons and The Mysterious Husband.

The years 1794 and I795, however, form Cumberland's second period of power, and find him dramatic writer-in-ordinary to the London theatres. Besides The Box Lobby Challenge, were performed The Jew, The Wheel of Fortune, and First Love. The Jew was widely known in Germany and Austria, Goethe himself acting Belcour at Weimar. ${ }^{12}$ This period was the brief lightning before the night of the later years.

With genius gone Cumberland seemed to write with renewed industry, evidently composing under the pressure of necessity, for The Widow's Only Son gives advice to an author 'not to write for bread till he has learnt to live without it. ${ }^{13}$ This is the third period of dramatic weakness. Of the score of plays written in these years, none has escaped oblivion.

Cumberland's position, in spite of many bad plays, as the most successful writer of sentimental comedy was due, in some measure, to his distinction of birth, education, and social position. As the grandson of Bentley and the descendant of many distinguished churchmen, 'the elegant Cumberland,' as he was frequently called, lent dignity to the writing of plays. After the acting of The Fashionable Lover, Doctor Hoadley wrote Garrick: 'I hope the nonsense of the reviewers will not make Mr. C. be silent; we want writers who think and act like gentlemen for the stage. ${ }^{14}$ It was understood that Cumberland stood for

12 In 1777, at the new Weimar-Tiefurt Court Theatre, Eckhoff, the actor, played Stockwell, and Goethe, Belcour. See Lewes, Life of Goethe, 238.

13 The London Times, June 8, 1810.

14 Private Correspondence of David Garrick, 1.465-6. 
higher dramatic ideals. 'Mr. Cumberland,' says The Analytical Review for May, I795, 'has long held a place of considerable distinction among our writers for the stage; and his correct and classical dramas have contributed in no small degree towards checking the taste for low buffoonery, which has of late years met with too much encouragement.' Cumberland was, in Scott's phrase, 'in the first rank of literature, and . . . in the first rank of society.' ${ }^{15}$ So The European Magazine for March, I 802, says that 'Cumberland has been for many years the ornament of the British Drama.' But it must be remembered that in matters of social position Cumberland was something of a poseur. The Saturday Review of November 29, I 862 , has a pertinent comment: 'When Cumberland intimated that he wanted to be treated, not as a writer of plays, but as a gentleman, the world of his day did not know what he was at, and thought he gave himself airs; but every successful author would say so now, and every one would take the feeling for granted.' It is more likely that 'the world of his day' was right, for Cumberland's pretensions in society were well known.

Cumberland deals hard blows at the dramatist who writes of a society he does not know. 'If,' he says, 'the author conceives himself at liberty to send his characters on and off the stage exactly as he pleases, and thrust them into gentlemen's houses and private chambers, as if they could walk into them as easily as they can walk through the side scenes, he does not know his business: If he gives you the interior of a man of fashion's family, and does not speak the language, or reflect the manners, of a well-bred person, he undertakes to describe company he

${ }^{15}$ Novels of Swift, Bage and Cumberland, 'Prefatory Memoir to Cumberland,' 43. 
has never been admitted to, and is an imposter.' Likewise in a letter to Prince Hoare he adds: 'In common life there is nothing so out of character as an under-bred man, when he grows familiar, and puts himself at his ease with you. This remark ought to be everlastingly kept in sight by writers for the stage. If they have not obtained a knowledge of the style and manners of people in high and elegant life, by consorting with them before they set about to represent them on the stage, they had better never think of making the attempt.' ${ }^{16}$

Cumberland's belief in social position was another phase of the personality most suited to express itself in sentimental comedy. For in Richard Cumberland were

- fused all the elements of that strange state of mind of the age, best named 'sensibility.' In thinking of Cumberland, one is reminded of his character, Lord Sensitive, in First Love. 'Am I not right,' says Lady Ruby, '. . . is he not very, very-Sensitive?' ${ }^{17}$ Cumberland's was the temperament to interpret rightly the delicate nuances of sentimental emotion. With feelings rather quick than deep, he tended to create for himself a world of sentiment as unreal as that of his own comedies; there occur in his letters and in the Memoirs, passages filled with the vapid emotion of a dialogue from The Brothers or the story of Le Fevre. Much of his correspondence has the courtly phrasing of the old school. 'As,' he writes Miss Farren, 'you are born to have all mankind at your feet, you will not refuse the addresses of an old poet, who is as much devoted to your fame as any man can be. ${ }^{18}$ The theme is

${ }^{16}$ The Cabinet of Polite Literature, May, 1807. 'Letter to Prince Hoare.'

17 First Love, 4.1.

18 Posthumous Letters to Francis Colman, and George Colman, the Elder, 227. 
different but the tone the same as that of Miss Aubrey's letter in The Fashionable Lover, and the reminiscent softness of the Memoirs is very like Bridgemore's in the same play, or that of other aged gentlemen whose wont it was to return in the fifth act to sentimentalize.

Cumberland, moreover, was fitted to write sentimental comedy by his genuine, but punctilious, virtue. The proper ending could not fail to come from the pen of 'the moral Cumberland.' The field of sentimental comedy, which offered rewards to anyone with industry and persistence, was easily conquered by Cumberland, who possessed these qualities in a high degree, and more than average ability. Though Cumberland was worsted by Goldsmith and men of the rival school, he easily vanquished such playwrights as Mrs. Lennox, Mrs. Griffith, and Kelly.

One reason for Cumberland's superiority over his rivals in sentimental comedy is clear. Sunk in sentiment as he seems, he is less under the sway of the tearful muse than Kelly or Holcroft. 'You are as dull as a sentimental comedy,' says one of his characters; Cumberland prided himself upon his freedom from false as opposed to true sentiment, which was supposed to 'flow naturally from [the] situation and circumstances; and not seem to be imposed upon the character by the author.' In his preface to Nanine, Voltaire says: 'Comedy, I repeat, may have its moods of passion, anger, and melting pity, provided that it afterwards makes well-bred people laugh. If it were to lack the comic element and be only tearful [larmoyante], it is then that it would be a very faulty and very disagreeable species.' So sentimental comedy in England seemed to separate in two indefinitely merging classes, the serious, tearful type, similar to the French 
comédie larmoyante, and the lighter drama, less oppressed by sentiment, and relieved by comic scenes, like the comédie bourgeoisie, and still more like the English domestic drama, which developed through Steele, Cibber, and Lillo. It may, then, broadly speaking, be said that Kelly and Holcroft incline towards the more tearful French school, while Cumberland, with an occasional exception, continues the English tradition. In support of this statement, it is noticeable that Kelly is openly connected with the French school, for False Delicacy enjoyed a fame in France which none of Cumberland's plays ever attained there. But Cumberland repudiates French influence. His models are Fielding, Smollett, and English dramatists; his plays are filled with English scenes and characters; and his attitude is set forth in the prologue to The Brothers: 'You shall receive and judge an English play.' Likewise, in the prologue to The Fashionable Lover Cumberland declares the play to be:

Home-bred and born, no strangers he displays,

Nor tortures free-born limits in French stays.

The use of English scenes and English characters in Cumberland's plays brought more natural dialogue and less sentiment. Thus the moral speeches in his comedies tend to be shorter, less frequent, and less tragically sentimental than in the plays of Kelly, Holcroft, and the other dramatists. We have many moral epigrams like Belcour's: 'I am the offspring of distress, and every child of sorrow is my brother, ${ }^{, 19}$ or Fanny's in The Brothers: 'Ay, ay, brother, a good conscience in a coarse drugget is better than an aching heart in a silken gown, ${ }^{, 20}$ or even

19 The West Indian, 1.1.

20 The Brothers, 1.1. 
Blushenly's affected lines to Lady Paragon: 'The playfulness of your spirit shews the purity of your nature; a heart like your's wou'd make an angel's face superfluous; I think with too much reverence of your virtue to recollect that you are beautiful.'21 But these are more temperate than typical lines of Holcroft: 'My heart,' says Lady Mortimer to Sir Frederick, 'sighs for an acquaintance, a mate, that like itself is subject to all the sweet emotions of sensibility!-Yes, it was the first wish of my soul to find this correspondent heart! a heart beating with the same ardour, vibrating to the same sensations, . . . shrinking from the same pangs; pliant, yet firm; gentle, yet aspiring; passionate, yet pure!'22

Moreover, Cumberland's dialogue, commended by critics in the worst of his plays, attains occasional eminences of wit not equally apparent in his rivals' drama. The following example is taken from The Natural Son:

Penelope: A lady write poems! I wonder any Lady will do such a thing, 'tis sure destruction to the complexion.-Doctor Calomel says, a lady, to preserve her beauty shou'd not even think; he has wrote a book purposely to dissuade people from reading.

Phoebe: Every book he writes will do that. ${ }^{23}$

In addition to wit, the dialogue of Cumberland's comedies constantly displays evidences of an excellent education, and a knowledge of good society. Scott says that Cumberland knew the great world, and it is not strange that his dialogue reflects more polish than that of Kelly, a tavern-keeper's son, or Holcroft, son of a shoemaker. 'Cumberland's forte,' says Genest, 'lay in the

21 The Natural Son, 1.1.

22 Holcroft, Seduction, 5.4.

${ }^{23}$ The Natural Son, 1.1. 
writing of dialogue. ${ }^{\prime 24}$ What Mr. Millar calls Cumberland's 'natural taste' forms a large element in an estimate of the dramatist.

In a letter to Prince Hoare 'On Dramatic Style,' in The Cabinet of Polite Literature for May, I807, Cumberland gives interesting hints as to his method of composition. After praising Congreve's style as 'terse, compressed, and pointed,' he analyses a conversation between Fainlove and Mirabel in The Way of the World, and points out that 'Congreve builds one speech upon another, and works his climax point by point.' 'He warns his readers, however, against Congreve's inelegance: 'If they [writers] resort to his table for clean and wholesome fare, they will only be entertained with tainted fragments, disguised by high-seasoned sauces and stimulating spices.'

The many sentimental comedies of Cumberland, like those of Kelly, delight in showing virtue or innocence in distress. Thus The Brothers opens with a picture of Old Goodwin's family, ruined by a 'merciless landlord,' forced to 'plough the ocean' ${ }^{26}$ for subsistence, yet bearing all with fortitude, and saving the lives of others more unfortunate than themselves. In The Fashionable Lover, Augusta Aubrey, a girl of refinement, is suddenly left alone in a brothel; in First Love, Sabina Rosny is deserted by her husband, Lord Sensitive; in The Impostors, Elinor is ill treated by her lover, Sir Charles Freemantle; and in A Hint to Husbands, Lady Transit, the patient wife, is compelled to endure all manner of neglect and even insult from her husband. Situations like these pleased the dramatist and his audience, and inspired, in

24 Genest, 8.398. See also Millar, The Mid-Eighteenth Century, for a general background for Cumberland's drama.

25 The Brothers, 1.1.

26 Ibid., 1.5. 
turn, scenes in which the tender sympathies of the other characters of the play are aroused to rescue the suffering ones from their dilemmas. Thus, in The Wheel of Fortune, Emily's penniless lot evokes Penruddock's compassion, and provides a scene in which his misanthropy changes to enthusiastic benevolence, and ends in bestowing upon the lady and her lover a fortune. Similarly, Sheva befriends the unfortunate Eliza in The Jew, and Lady Paragon in The Natural Son offers her heart and hand to Blushenly. For such scenes the sentimental dramatist strove, and for them he was likely to sacrifice natural action and sound psychology. Such situations are generally pervaded by a languid atmosphere of gloom and pity, either for self or for another; for vigour of thought is substituted a tenderness of sentiment which a more masculine dramatic ideal despises. They are all covered, as Leslie Stephen says, with the 'mildew' of sentiment. One bit of dialogue is illustrative. In The Jew Eliza and her mother converse:

Mrs. R.: Heaven bless him to the extent of his deservings! On him rests all our hope; to him we cling, as to the last dear relic of our wrecked nobility. But he's a man, Eliza, and endowed with strength and fortitude to struggle in the storm; and we are weak helpless women, and can do no more than suffer and submit.

Eliza: True, but there is a part allotted to the weakest, even to me; an humble one indeed, and easily performed, since nothing is required but to obey, to love you, and to honour you. ${ }^{27}$

'Mr. Cumberland's comic muse,' says Davies rightly, 'seems to be always in mourning, ${ }^{28}$ and Doctor Hoadley writes Garrick: 'I have shed tears more than once over

27 The Jew, 2.1 .

${ }^{28}$ Memoirs of the Life of David Garrick, 2.270. 
writing of dialogue. ${ }^{24}$ What Mr. Millar calls Cumberland's 'natural taste' forms a large element in an estimate of the dramatist.

In a letter to Prince Hoare 'On Dramatic Style,' in The Cabinet of Polite Literature for May, I807, Cumberland gives interesting hints as to his method of composition. After praising Congreve's style as 'terse, compressed, and pointed,' he analyses a conversation between Fainlove and Mirabel in The Way of the World, and points out that 'Congreve builds one speech upon another, and works his climax point by point.' 'He warns his readers, however, against Congreve's inelegance: 'If they [writers] resort to his table for clean and wholesome fare, they will only be entertained with tainted fragments, disguised by high-seasoned sauces and stimulating spices.'

The many sentimental comedies of Cumberland, like those of Kelly, delight in showing virtue or innocence in distress. Thus The Brothers opens with a picture of Old Goodwin's family, ruined by a 'merciless landlord,' ${ }^{25}$ forced to 'plough the ocean' ${ }^{26}$ for subsistence, yet bearing all with fortitude, and saving the lives of others more unfortunate than themselves. In The Fashionable Lover, Augusta Aubrey, a girl of refinement, is suddenly left alone in a brothel; in First Love, Sabina Rosny is deserted by her husband, Lord Sensitive; in The Impostors, Elinor is ill treated by her lover, Sir Charles Freemantle; and in A Hint to Husbands, Lady Transit, the patient wife, is compelled to endure all manner of neglect and even insult from her husband. Situations like these pleased the dramatist and his audience, and inspired, in

${ }^{24}$ Genest, 8.398. See also Millar, The Mid-Eighteenth Century, for a general background for Cumberland's drama.

25 The Brothers, 1.1.

26 Ibid., 1.5. 
turn, scenes in which the tender sympathies of the other characters of the play are aroused to rescue the suffering ones from their dilemmas. Thus, in The Wheel of Fortune, Emily's penniless lot evokes Penruddock's compassion, and provides a scene in which his misanthropy changes to enthusiastic benevolence, and ends in bestowing upon the lady and her lover a fortune. Similarly, Sheva befriends the unfortunate Eliza in The Jew, and Lady Paragon in The Natural Son offers her heart and hand to Blushenly. For such scenes the sentimental dramatist strove, and for them he was likely to sacrifice natural action and sound psychology. Such situations are generally pervaded by a languid atmosphere of gloom and pity, either for self or for another; for vigour of thought is substituted a tenderness of sentiment which a more masculine dramatic ideal despises. They are all covered, as Leslie Stephen says, with the 'mildew' of sentiment. One bit of dialogue is illustrative. In The Jew Eliza and her mother converse:

Mrs. R.: Heaven bless him to the extent of his deservings! On him rests all our hope; to him we cling, as to the last dear relic of our wrecked nobility. But he's a man, Eliza, and endowed with strength and fortitude to struggle in the storm; and we are weak helpless women, and can do no more than suffer and submit.

Eliza: True, but there is a part allotted to the weakest, even to me; an humble one indeed, and easily performed, since nothing is required but to obey, to love you, and to honour you. ${ }^{27}$

'Mr. Cumberland's comic muse,' says Davies rightly, 'seems to be always in mourning, ${ }^{, 28}$ and Doctor Hoadley writes Garrick: 'I have shed tears more than once over

27 The Jew, 2.1.

${ }^{28}$ Memoirs of the Life of David Garrick, 2.270. 
Mr. Cumberland's comedy. ${ }^{29}$ This characteristic excerpt of dialogue is from The Natural Son:

Lady Paragon [to Blushenly]: The delicacy of your principle has determin'd you to meet my affection with indifference.

Blushenly: O cruel, cruel honour.

* * * *

Lady Paragon: Oh Harry! if you are still so blind as not to see the openest heart in nature, legible by every eye but your's, I'll sooner do a violence to my sex's delicacy, by an avowal of my love, than to leave it in your power to make a plea of ignorance.

Blushenly: You shall not do your dignity that wrong; I see and know your heart. ${ }^{30}$

It may be observed, as a general statement, that Cumberland, as in the example quoted above, is more direct, more personal, than Kelly in his moral sentiment. There seem absent in Cumberland's plays speeches of the impersonal quality found in False Delicacy. Thus Lady Betty says: 'The woman that wants candour where she is address'd by a man of merit, wants a very essential virtue; and she who can delight in the anxiety of a worthy mind, is little to be pitied when she feels the sharpest stings of anxiety in her own.' ${ }^{31}$ And says Sidney: 'There is something shocking in a union with a woman whose affections we know to be alienated; and 'tis difficult to say which is most entitled to contempt, he that stoops to accept of a pre-engaged mind, or he that puts up with a prostituted person. ${ }^{32}$

The mournfulness of sentimental drama presents a striking contrast to the gaiety of Restoration comedy. It

29 Private Correspondence of David Garrick, 1.465.

30 The Natural Son, 4.1.

${ }^{31}$ Kelly, False Delicacy, 2.2.

32 Ibid., 5.1. 
arose from an excess of those emotions of humanity which the Restoration playwrights steadily derided. As their comedy had excluded all pity and sympathy, so now the sentimental school adopted the opposite extreme, and opened wide 'the sluices of benevolence.' Since their moral purpose precluded a favourable representation of fashionable life, the sentimental writers, and, in particular, Cumberland, turned to the more familiar scenes of English domesticity. A thread, at least, of humble story runs through almost every comedy of Cumberland's, and some, like The Box Lobby Challenge and The Jew, link their entire plot with the people of the English middle, or even lower, classes. So Belcour, the hero of The West Indian, is the son of a merchant, and weds the daughter of a British officer, after dealings with the Fulmers, dishonest booksellers; The Brothers is concerned with the poorer class of country gentry, and, in a lesser degree, with the fortunes of a fisherman's family; while the scenes of The Jew are laid alternately in the houses of a London merchant and of a Hebrew money-lender. Cumberland proposed showing on the stage the moral lives of the people of his own audiences. He frankly neglected the joys and sorrows of the nobility, and thus continued the tradition of the domestic drama of Rowe, Cibber, and Steele. So his heroes are young men of sound morals, of humble family, but in disgrace with fortune, like Belfield Junior in The Brothers, or Tyrrel in The Fashionable Lover, or Frederick in First Love. His villains, on the other hand, are apt to be of dissipated life, of noble birth, and, for the time being, prosperous, like Lord Abberville or Lord Transit of The Fashionable Lover and A Hint to Husbands. At other times, Cumberland shows us lords and ladies in ridiculous lights that we may compare 
them with the more natural men and women of the middle classes. Such are Lady Rusport, Sir Benjamin Dove in The Brothers, or Lord Sensitive in contrast to Stockwell, Belfield Junior, and David Mowbray in First Love.

In scenes of humbler life we are permitted to watch the uneasy actions of Weazle or Earling, unscrupulous lawyers in The Wheel of Fortune and False Impressions; we are taken to the house of Billy Bustler in First Love, to see the carving of a goose; or in The $W$ alloons we are present at a grog party in which Pat Corey, Bumboat, and Tipple become very drunk. It is not the existence of such scenes and characters-there are similar ones in Kelly - but their frequency which is significant. 'The constant intrusion of low comedy figures, sometimes to the subordination of the regular characters of sentimental comedy, indicates only one fact-that Cumberland was aware of the opposition to sentimental comedy, as exemplified in Goldsmith's plays, and was influenced, perhaps unconsciously. In comparison with the plays of Kelly and Holcroft there is, at times, in the drama of Cumberland a comparatively natural and wholesome atmosphere. This is perceptible in characters like Belcour or Major O'Flaherty in The West Indian; in The Brothers, the scene of which is on the coast of Cornwall, the reader feels throughout the breath of the sea. The Brothers has the materials for healthy, natural comedy.

But if Cumberland was willing, in an occasional scene or character, to yield to more natural influences, he never deserted the moral aims of sentimental comedy. Thus characters from humble life are chosen not merely to divert, as is Goldsmith's purpose, but to instruct. Cumberland wishes us not merely to be amused at Billy Bustler, but also to see the good in a righteous, though 
humble, life. Several characters in Cumberland's plays remind us of Tony Lumpkin, and are, perhaps, somewhat influenced by him, but all have a tiresome moral strain that dampens any mirth we may feel. There is no sound laughter in Cumberland.

His plots, as Mr. Waterhouse has said, are always based upon the trials of a pair of lovers. Since the end is sentiment, the plot is but a means, and the dramatist wastes little concern upon the probability or consistency of his situations. Thus the obstacles to the union of the lovers are often of the slenderest nature, and sometimes can hardly be said to exist at all. The difficulty may hang upon a mistaken identity absurdly obvious to all but the lovers themselves. Such is Belcour's belief that Louisa is Dudley's mistress, Tyrrel's misinterpretation of Miss Aubrey's meekness towards Lord Abberville, or even Violetta's incredible error in believing that Sophia in saying 'Belfield' means the elder brother. The hindrance is often the opposition of a parent, or the lack of a fortune and, occasionally, mere diffidence in one of the lovers. Thus the difficulties do not spring from the circumstances of the action, but are deliberately imposed by the dramatist. Sometimes the rilisunderstanding between the lovers threatens to yield to an early éclaircissement, and then the dramatist hastens to delay the action or to introduce new stage business. Thus, although Tyrrel and Miss Aubrey are virtually united at the end of the third act of The Fashionable Lover, their final betrothal does not occur until the fifth act, the fourth being taken up with irrelevant dialogue, and the appearance of a lost father for Miss Aubrey.

Cumberland also lacks expositional power. The situations are not made clear at the beginning, and important 
characters are often delayed in their first entrance by unimportant incidents. Cicero, in Cumberland's first play, does not appear until the third act. So in the first act of The West Indian Stockwell confides the main secret of the plot to Stukely, but this character plays no further part in the action.

Besides surprises, chance meetings, and other devices of comedy, Cumberland's foibles appear plainly enough. $\mathrm{He}$ is excessively fond of scenes of great contrast, with the low and high worlds meeting face to face. Thus we see the misanthrope Penruddock in the ballroom, or Jack Nightshade in the art gallery. He likes quarrel scenes between husband and wife; the Doves, the Wrangles (in First Love), and the Transits are entertaining, if not original, couples. He takes pleasure in seeing a rough gallant like Jack Crotchet in The Box Lobby Challenge smoke a pedantic spinster such as Di Grampus. Other favourite scenes are those of the quack doctor, occurring in The Sailor's Daughter, A Word for Nature, and The Last of the Family, and the feigned madness scenes such as in the last-named play, and in The Days of Yore.

Cumberland's regard for the romantic reunion scene is apparent in almost every comedy. They come suddenly, unexpectedly, from remote parts of the world, fathers, lovers, and husbands. Sentiment is supreme. This dialogue from the end of the fourth act of The Fashionable Lover is typical:

Aubrey: You are in error; you are not an orphan; you have a father, whom, thro' toil and peril, thro' sickness and thro' sorrow, Heaven has graciously preserved and blest at length his unremitting labours with abundance.

Tyrrel: Did I not tell you this? Bear up.

Aubrey: Yes, virtuous Augusta, all your sufferings terminate 
this moment; you may now give way to love and happiness; you have a father living who approves your passion, who will crown it with a liberal fortune, who now looks upon you, speaks to you, embraces you. ...

Tyrrel: See how her colour flies-She'll faint.

Aubrey: What have I done? Dear innocent, look up.

Miss Aubrey: Oh, yes, to Heaven with gratitude for these divine vouchsafements-I have a father then at last-Pardon my tears; I'm little used to happiness, and have not learned to bear it.

Cumberland's other faults of plot pale before his singular methods in effecting a dénouement. The difficulties of The West Indian are caused by the libertinism of Belcour. When these seem insurmountable, Belcour repents and the difficulties vanish. The settled and malignant purpose of Penruddock in The Wheel of Fortune promises the ruin of the Woodvilles, and of Emily Tempest. But Penruddock relents, and there follows a general reconciliation. Lord Sensitive has lived a treacherous and dissolute life. But he suddenly gives up Lady Ruby, and returns to Sabina, his abandoned wife. Scarcely a play is without its repentance in the last act, and its accompanying arbitrary change of a principal character. Thus in a single speech characters alter the habits of a lifetime. Belcour becomes austere in morals, Penruddock doffs his misanthropy, and Lord Sensitive gladly accepts domestic fetters.

The radical alteration of character in the last act is a result of the dependance of sentimental comedy upon the happy ending, and the inability of the dramatist to evolve his conclusion by the logical development of character and situation. But it should be observed that the dramatist was only following the traditions of his art. In sentimental comedy psychology was neither asked nor given. The two essentials, sentiment and a happy ending, Cum- 
berland has in abundance. Contemporary critics found fault, not with the unnaturalness of characters like Belfield Senior, or Lord Abberville, but with the flaws in the mechanism of their favourite devices, such as the jewel episode in The West Indian, or the chance meeting of Colin Macleod and Miss Aubrey in The Fashionable Lover.

Besides the mechanical reason for change of character was the necessity of showing in the dénouement virtue triumphant. Lines in Garrick's prologue to She Stoops to Conquer come near to Cumberland's attitude:

Let not your virtue trip: who trips may stumble, And Virtue is not Virtue if she tumble.

Since the happy ending was indispensable, the evil-doer could not be justly punished, and the only alternative was his repentance. In this manner, characters like Belfield Senior and Lord Abberville easily escape the disgrace they richly deserve.

Another means of bringing about a dénouement used by Cumberland is the removal of obstacles by a character somewhat detached from the main plot. Ar example of this is the unexpected appearance of Miss Aubrey's father in The Fashionable Lover, the return of Lady Dangle's husband in The Walloons, or the arrival of Varland with a new will in The West Indian. Similarly, Mortimer bestows a fortune on Tyrrel in The Fashionable Lover, and Rueful acknowledges Blushenly in The Natural Son. Still another obvious weakness of Cumberland's plots is his premature revelation of the end of his story. Doran exaggerates when he says that 'all Cumberland's dénouements may be conjectured before the curtain falls on his second acts, ${ }^{13}$ but many times, ${ }^{33}$ Annals of the Stage, 2.70. 
indeed, little action of importance is left for the last two acts of the play. The outcome of False Impressions cannot be in great doubt after Algernon's entrance into Lady Cypress's family; Penruddock's purpose is clear early in the play; and the lighter plays, such as The Last of the Family, The Eccentric Lover, and Lovers' Resolutions, hardly leave Cumberland's intentions in doubt after the first act. Fielding's damning of all fifth acts might be easily applied to the third acts of Cumberland's plays.

Cumberland wrote nine tragedies. Of three based upon classical subjects, only one, The Sybil, or The Elder Brutus, was performed, and this in an altered form seven years after its author's death. The two others, The Banishment of Cicero and Tiberius in Capreae, were never accepted by the managers of Covent Garden or Drury Lane. Torrendal and The False Demetrius appeared in the Posthumous Dramatick Works. The Arab was acted once, and The Battle of Hastings had but a brief day. Two tragedies of the nine, The Carmelite and The Mysterious Husband, were successful. Cumberland lacked the power to write convincing tragedy. Of the conception or exposition in drama of a single great idea he was incapable. His tragedies contain merely the elements of sentimentaI comedy shrouded in a deeper gloom.

The Carmelite opens with a shipwreck, and the action takes place near a monastery on the Isle of Wight. The plot is concerned with the usual pair of lovers, but a tragic setting is created by the circumstances:

Twenty long years his lady mourns him dead,

And bathes with faithful tears a widow'd bed. ${ }^{34}$

34 The Carmelite, Prologue. 
The obstacles to the union of the couple in the first act are not apparent to the reader, but Cumberland defers it until the fifth by the devices of comedy. Gyfford surprises and overhears Matilda, and Saint Valori believes Montgomeri to be his wife's lover. Hildebrand repents during the first three acts, and dies, forgiven for a sin which he never committed. Hildebrand swoons at the revelation of Saint Valori's identity, and Saint Valori himself faints as a result of his harrowing emotional experiences. The action of the play is retarded by long, dreary emotional scenes between Matilda and Montgomeri, and Hildebrand and Saint Valori. Cumberland's dialogue, easy in comedy, is strained and unnatural in the verse of tragedy. Matilda's most important speech to Hildebrand follows:

Mercy! thou man of blood, thou hast destroyed it,

It came from heaven to save Saint Valori:

You saw the cherub messenger alight

From its descent; with outspread wings it sate,

Covering his breast; you drew your cursed steel

And through the pleading angel pierc'd his heart.

Then, then the moon, by whose pale light you struck

Turn'd fiery red, and from her angry orb

Darted contagious sickness on the earth;

The planets in their courses shriek'd for horror

Heav'n dropt maternal tears. ${ }^{35}$

In The Battle of Hastings there is very little tragedy, and no battle. Matilda, the woman scorned, forgives the lovers in the fourth act, and Harold expires without the slightest effect upon the plot. The diction is better in The Battle of Hastings, but the same mournful atmosphere pervades the play. Cumberland's tragedy is a kind of

${ }^{35}$ The Carmelite, 4.1. 
exalted sentimental comedy. The Mysterious Husband, Cumberland's only trial of domestic tragedy, is an excellent continuation of the traditions of Steele, Cibber, and Lillo.

Cumberland's adaptations, four in number, were failures. The author was wrong in believing that in examining the brilliancy of a diamond few people throw away any remark upon the dulness of the foil.' Likewise, his operas, musical entertainments, and occasional pieces achieved nothing, being hastily composed, and unsuited to his talents.

When we consider the characters in these numerous kinds of drama we find that, both in tragedy and comedy, they lack variety, and, save in a few striking instances, originality. The approximately three hundred figures of the comedies fall easily into a dozen distinct types. The heroes, pleasant, correct young men, of infinite polish, are variously named, but act and think alike. There may be mentioned Algernon, Sir Charles Freemantle, Frederick, Worthington, Montgomery, Clifton, Blushenly, Charles Manlove, Belfield Junior, Sentamour, Tyrrel, and Rivers. Cumberland's heroines are his happiest efforts. His breeding, his education, and his sensibility, all enabled him to create feminine characters of charm and grace. Elinor, Eliza, Lady Transit, and Sophia are of gentler mould, while Emily, Lady Ruby, Mrs. Chevely, Lady Paragon, and Lady Davenant seem to direct the action of the plays with their energy and spirit. Cumberland's heroines have, indeed, been accused of being over-zealous, and Charlotte Rusport was called 'a forward baggage.' The wooing is usually done by the heroine.

The villains of Cumberland's comedies are of two kinds. One is the hesitating, irresolute type, such as Lord 
Transit, Lord Sensitive, or Belfield Senior, whose 'whole life [will] be employed in acts of justice and atonement., ${ }^{38}$ The other is the stage or melodramatic villain, such as Father Sullivan and Don Pedro. These dominate their respective plays and are exceedingly effective on the stage. An excellent example of the repentant villain is Daggerly, Father Sullivan's accomplice in The Walloons. Says he: 'How it stings me! curse on't! it is impossible to keep it off-conscience, thou devil eternal, will nothing silence thee, will nothing smother thee? I have deceiv'd myself, there is an immortality, and thou art! O God! I do repent. ${ }^{37}$

A favourite character of Cumberland's is the unattractive spinster, such as Mrs. Dorothy, or Mrs. Phoebe Latimer, who is 'a virgin in the bloom of half a hundred; vain, rich, pedantic,' or Lindamira with her eternal manuscript. These ladies are usually pursued by clever rascals who finally cheat them of their fortunes. The various plays muster an army of buffoons who seem sadly deficient in the vis comica, and who range in effectiveness from the brisk wit of Scud, the apothecary, to the boring aphorisms of Peter and Andrew in The Confession. Cumberland's comic scenes were partly induced by the necessity of competing with the excellent humour of his rivals, Colman and Murphy. Mr. Millar praises Cumberland's humorous scenes. Henpecked husbands are numerous, the excellent caricature, Sir Benjamin Dove, being in the lead, followed by Sir Toby Truckle of The Passive Husband, and Sir Solomon Dangle. Other familiar figures are the benefactor, such as Sheva, Penruddock, or Sunderland in The Note of Hand, the adventurer, such as Polycarp in The Impostors, and the moral friend, Sydenham in The Wheel

36 The Brothers, 5.2, Belfield Senior.

37 The Walloons, 4.3. 
of Fortune and Heartright in A Hint to Husbands, serving as examples.

It will seem that most of these types may be traced to sources in earlier drama. Characters like Scud, who is almost Jonsonian, and Beau Tiffany in The Last of the Family, and plainly taken from Elizabethan and Restoration plays. Yet in several characters Cumberland struck fire. 'Es sind,' says Hettner, - 'vortreffliche Charakterskizzen, die mit Recht die lebendigste Theilnahme fanden. ${ }^{38}$ In Captain Ironsides, Belcour, Colin Macleod, Sheva, and Penruddock, Cumberland goes beyond the mediocrity of sentimental comedy. These characters are unreal, yet possess elements of reality. Thus Belcour is a composite figure of several deliberately chosen attributes, namely, licentiousness, generosity, and honour. The result is unreal, but is neither the $x$ nor $y$ type into which Mr. Waterhouse divides Cumberland's characters. These characters lack subtlety and consistency, yet possess a complexity which springs not from mature observation of life, but rather from a conscious selection of qualities. Dr. Ward says that Cumberland 'possessed a genuine power of characterization. ${ }^{39}$

Cumberland drew impossible characters because he was an idealist. While far from being insensible to the applause of his audiences, he nevertheless believed sin. cerely in the mission of sentimental comedy to reform abuses, and to correct English prejudices. To accomplish this purpose he exhibited characters endowed with the qualities denied them by popular report. Hence the benevolent Jew, the liberal Scotchman, or the honest attorney. 'I looked,' he says, 'into society for the purpose of discovering such as were the victims of its national,

38 Hettner, Geschichte der englischen Literatur, 1.520.

39 Lillo, London Merchant and Fatal Curiosity, Ward ed., 34. 
professional, or religious prejudices; in short for those suffering characters, which stood in need of an advocate, and out of these I meditated to select and form heroes for my future dramas, of which I would study to make such favourable and reconciliatory delineations, as might incline the spectators to look upon them with pity, and receive them into their good opinion and esteem.'

This basis of Cumberland's sentimental comedy is a kind of shallow idealism, and the faults of his plot and character are due to a desire to show men and women as he would wish them to be rather than as they are, and to the sincere belief in the didactic value of the stage. It was his faith in this kind of drama which kept Cumberland writing sentimental comedy in the nineteenth century, and which made him mistake She Stoops to Conquer for an 'eccentric production.' Cumberland was the upholder of 'true' sentiment. The Monthly Review for August, I 778, comments upon sentiment in verse and prose:

First for true grounds of sentimental lore, The scenes of modern comedy explore;

Dramatic homilies! devout and sage, Stor'd with wise maxims, 'both for youth and age.'

But chief, let Cumberland, thy muse direct; High priest of all the tragic-comic sect!

‘. To banish sentiment from the stage, would be as injurious to it, as to suffer it to usurp more than it is entitled to: When sentiment is subservient to character, and breaks forth from the humour and passions of the Dramatis personae the effect is as powerful, as it is instructive and entertaining. . . .' 'Let me,' Cumberland writes, 
'cast one dart at Prejudice . . . , and I shall call it victory, if it pierces no farther than the stroke which Abdiel gave Satan. ${ }^{40}$

Cumberland attacked evils of the time not merely through the characters, but by means of the dialogue. In a half-dozen plays duelling is censured. A specimen of the outbursts against this evil occurs in False Impressions when Lady Cypress exclaims: 'No, I regard a duellist with horror; I hold him as an agent of the enemy of mankind, sent to disturb society, and rend the parent's and the widow's hearts asunder., ${ }^{41}$ The Wheel of Fortune and The Note of Hand are dramatic sermons directed at gambling, and The Choleric Man impugns the game laws. Similarly, Lady Transit condemns drunkenness in A Hint to Husbands, and the epilogue to False Impressions runs:

He writes, and ever to some moral end, Because the world is not too good to mend.

A letter to The Gentleman's Magazine for February, I 778, defends sentimental comedy, and indirectly indicates Cumberland's position as its leader. The communication is headed, 'Animadversions on the Moral Tendency of the School for Scandal,' and says: 'It has been said that this is a second attempt to destroy the taste for sentimental comedy revived by $\mathrm{Mr}$. Cumberland. It will be readily acknowledged, that the plays of that gentleman may tend to produce an affectation of sentiment, but it is better to affect sentiment than vice: and Mr. Cumberland has judiciously executed the whole duty of an author,

40 Private Correspondence of David Garrick, 1.430.

${ }^{41}$ False Impressions, 3. 
which is, not only to paint nature, but to paint such parts of it, as every good man would wish to see imitated.'

But a review of The Sailor's Daughter, one of the last plays written, in The Litcrary Journal of June I, I 804, shows the weakness of sentimental comedy: 'Nothing has tended more to degrade the drama in the public estimation than the introduction of that sentimental jargon which more or less defiles almost every comedy of our age. It has indeed become fashionable with the galleries to applaud the most hacknied and ridiculous sentiment, when uttered with due vociferation and contortion: but this is the utmost goal of its fame: no one cares to be twice the hearer of these new comic beauties; to read them twice, deprived as they are of scenery and acting, is beyond all human endurance. With such flowers, however, Mr. Cumberland must be conscious that his comedies often abound; and these, beautiful as he may think them, will prove the leaden weights which are ready to sink most of his pieces into the deep gulf of oblivion.'

It remains to say a word concerning Cumberland's plagiarism. No one may affirm that he stole recklessly or impudently from the ancients or moderns. His scenes and characters are influenced, but not dominated, by ghosts of the drama. On the other hand, he followed the rules of playwriting of the age, and, not gifted with originality, he borrowed much,-certainly more than he admitted, perhaps more than he himself realized.

'He has,' wrote Walter Scott, 'written comedies at which we have cried, and tragedies at which we have laughed.' ${ }^{{ }^{2} 2}$ Cumberland's dramatic career of half a century, starred with comedy, tragedy, and opera, is as strange as his own personality. The writer of fifty-odd

42 The Quarterly Review, May, 1809. 
plays, he survives as the author of one, The West Indian, and the student may count other plays of worth upon his hand. Yet his position in literature, if not high, is distinct. He was, as Henry Neele says, 'the last and the best of the Sentimental School. ${ }^{{ }^{* 3}}$

${ }^{43}$ Lectures on English Poetry, 153. 


\section{BIBLIOGRAPHY}

\section{NOTE}

This bibliography has two divisions. In the first division are the books written by Richard Cumberland. This part is subdivided into dramatic and non-dramatic work. In the second division are the books which have reference to Cumberland. The arrangement of the first division is chronological, of the second, alphabetical.

There is no collected edition of Cumberland's dramatic work. The more successful plays may be found in standard sets of eighteenth century drama. Others must be read in the first or second editions. Excellent texts of the plays occur in: (1) A Collection of Plays, London, 1774; (2) Bell's British Theatre, London, 1776, etc.; (3) The British Drama, edited by Walter Scott, London, 1804, etc.; (4) Mrs. Inchbald's British Theatre, London, 1808, etc. $^{1}$; (5) Steele and Cibber's English Comedy, London, 1810; (6) Mrs. Inchbald's Modern Theatre, London, 1811, etc.; (7) The Posthumous Dramatick Works of Richard Cumberland, London, 1813; (8) Dibdin's London Theatre, 1815; (9) Oxberry's Edition of Plays, Boston, 1822; (10) The London Stage, 1824; (11) Lacy's Acting Edition of Plays, London, [1850]; and (12) John Cumberland's British Theatre, London, 1826-32.

The list of plays includes first editions, and, in some instances, later publications, but does not, as stated in the Preface, aim to record all editions. At the end of the printed plays there follows a list of those unprinted or extant only in manuscript. These, too, are chronological, mentioned in the order of their stage production,

1 Volume 18 of this collection contains five of Cumberland's plays, viz., The Brothers, The West Indian, The Jew, First Love, and The Wheel of Fortune. 
or, if neither printed nor acted, according to the time of composition. Bracketed numbers following the plays refer to the collected editions of drama cited above.

In the second division no particular mention has been made of such works as The Dictionary of National Biography, The Encyclopedia Britannica, The Cambridge History of English Literature, or the New English Dictionary. The writer is particularly indebted to the following books: The Memoirs of Richard Cumberland, The Life of Richard Cumberland by William Mudford, English Drama of the Restoration and Eighteenth Century by Professor George H. Nettleton, and to the two essays by Mr. Osborn Waterhouse upon The Development of English Sentimental Comedy in the Eighteenth Century.

\section{CUMBERLAND'S WORKS}

\section{A. Dramatic Work}

Shakespear in the Shades. A Cento. [Never acted. Composed c. 1744. Selections printed in the Memoirs, (1806) 1. 5664.]

The Banishment of Cicero: a tragedy. London, 1761.

The Summer's Tale, A Musical Comedy of Three Acts, As it is Performed at the Theatre Royal in Covent-Garden. London, 1765.

Amelia; a musical entertainment of two acts. [Altered and abridged from The Summer's Tale.] London, 1768. [Another edition with alterations appeared at London in 1771.] The Brothers; A Comedy. As it is performed at the Theatre Royal in Covent-Garden. London, $1770 . \quad[2 ; \mathbf{3} ; \mathbf{4} ; \mathbf{5} ; \mathbf{8}$; 10.]

The West Indian: A Comedy. As it is Performed at the Theatre Royal in Drury-Lane. London, 1771. [This play had at least two other editions in 1771, and one in 1772. A German translation appeared at Hamburg in 1772, and a French 
version (L'Américain) at Paris in 1822.$] \quad[1 ; 2 ; 3 ; 4 ; 5$; 8.]

'Timon of Athens, Altered from Shakespear. A Tragedy. As it is Acted at the Theatre-Royal in Drury-Lane. London, 1771. The Fashionable Lover; A Comedy: As it is acted at the TheatreRoyal in Drury-Lane. London, 1772. [At least three other editions of this play appeared in 1772. A German version was printed at Leipzig in 1774.$] \quad[1 ; 2 ; 8 ; 10$.

The Note of Hand; or Trip to Newmarket. As it is acted at the Theatre-Royal in Drury-Lane. London, 1774.

The Choleric Man, A Comedy. As it is performed at the TheatreRoyal in Drury-Lane. London, 1775. [2]

The Battle of Hastings: a tragedy. As it is acted at the TheatreRoyal in Drury-Lane. London, 1778. [2]

Calypso; A Masque, In three Acts. As it is performed at the Theatre-Royal in Covent-Garden. London, 1779.

The Widow of Delphi or, the Descent of the Deities, A Musical Drama, of Five acts, As it is performed at the TheatreRoyal in Covent Garden. London, 1780. [Only the Songs were printed.]

The Mysterious Husband. A Tragedy in Five Acts, As it is acted at the Theatre-Royal, Covent-Garden. London, 1783. $[6 ; 10$.

The Carmelite: A Tragedy. Performed at the Theatre Royal Drury Lane. London, 1784. [A German translation was printed at Berlin and Leipzig in 1787.] $[2 ; 3 ; 6 ; 10$.

The Natural Son: A Comedy. Performed at the Theatre Royal Drury Lane. London, 1785. [2; 6.]

The Impostors: A Comedy. Performed at the Theatre Royal Drury Lane. London, 1789. [6.]

The Armourer. Songs . . . in the comic opera of the Armourer. London, 1793.

The Box Lobby Challenge, A Comedy. As performed at the Theatre-Royal, Hay-Market. London, 1794. [6.]

The Jew: A Comedy. Performed at the Theatre-Royal, DruryLane. London, 1794. [Five editions of The Jew were 
printed before 1796. The seventh edition appeared in 1801 . A German translation was printed at Königsberg in 1798.] $[4 ; 10 ; 11 ; 12$.

The Wheel of Fortune: A Comedy. Performed at the Theatre Royal, Drury-Lane. London, 1795. $[4 ; 10 ; 11 ; 12$.

First Love: A Comedy. Performed at the Theatre-Royal, Drury-

Lane. London, $1795 . \quad[2 ; 3 ; 4 ; 10$.

The Days of Yore: A Drama in Three Acts. Performed at the

Theatre-Royal, Covent-Garden. London, 1796.

False Impressions: A Comedy, In Five Acts. Performed at the

Theatre Royal, Covent Garden. London, 1797. [6; 10.]

The Clouds. 1797. See Non-dramatic Work.

Joanna of Misntfaucon; A Dramatic Romance of the Fourteenth

Century: As performed at the Theatre-Royal, Covent-

Garden. London, 1800.

The Sailor's Daughter: A Comedy. London, 1804.

A Hint to Husbands: A Comedy, In Five Acts, Now performing at the Theatre-Royal, Covent Garden. London, 1806.

The Jew of Mogadore, A Comic Opera, In Three Acts. London, 1808.

Twelve of Cumberland's plays appeared in The Posthumous

Dramatick Works of Richard Cumberland, in 1813:

The Sybil, or the Elder Brutus; a Tragedy. [Acted 1818.]

The Walloons; a Comedy. [Acted 1782.]

The Confession; a Play in Five Acts.

The Passive Husband; a Comedy. [A Word for Nature.

Acted 1798.]

Torrendal; a Tragedy.

Lovers' Resolutions.

Alcanor; a Tragedy. [The Arab. Acted 1785.]

The Eccentric Lover; a Comedy. [Acted 1798.]

Tiberius in Capreae.

The Last of the Family; a Comedy. [Acted 1797.]

Don Pedro; a Play in Five Acts. [Acted 1796.]

The False Demetrius. 
Palamon and Arcite. [The manuscript of this play is in The British Museum and was presumably written towards the end of Cumberland's life.]

\section{Unpublished Plays}

The Princess of Parma, A Tragedy. [1778.]

The Election, an Entertainment. [1778.]

The Elders. [1778. This play is ascribed to Cumberland by The Thespian Dictionary.]

The Bondman, a Tragedy. [1779.]

The Duke of Milan, a Tragedy. [1779.]

The Country Attorney, a Comedy. [1787. See the School for Widows.]

The School for Widows. [1789. An altered form of The Country Attorney.]

The Occasional Prelude. [1792.]

The Dependant, a Comedy. [1795.]

The Village Fête, an Interlude. [1797.]

The Victory and Death of Lord Nelson. [1805.]

The Robber. [1809.]

The Widow's Only Son. [1810.]

\section{Plays Neither Acted Nor Published}

Caractacus. [This play was written c. 1760 but was not acted; the manuscript was in Cumberland's possession in 1804.]

The Days of Geri. [This play is mentioned by Scott in a list of Cumberland's plays. See the Novels of Swift, Bage and Cumberland (Ballantyne's Novelist's Library) 'Prefatory Memoir to Cumberland,' 59.]

\section{B. Non-Dramatic Work}

A letter to the Bishop of $\mathrm{O}[\mathrm{xfor}] \mathrm{d}$. Containing some animadversions upon a character given by Dr. Lowth of the late Dr. Bentley. London, 1767. 
Odes. London, 1776.

Miscellaneous Poems, consisting of elegies, odes, pastorals, \&c., to-gether with Calypso, a masque. London, 1778.

Anecdotes of eminent painters in Spain, during the sixteenth and seventeenth centuries with cursory remarks upon the present state of arts in that Kingdom. 2 vols. London, 1782.

A letter to Richard, Lord Bishop of Llandaff, on the subject of his Lordship's letter to the late Archbishop of Canterbury. London, 1783.

The Observer. 1 vol. London, 1785. [Another edition in 5 vols. was published at London, 1786. The fifth edition, in 1798, was newly arranged with a translation of The Clouds.]

Character of the late Lord Viscount Sackville. London, 1785.

An accurate and descriptive catalogue of the several paintings in the King of Spain's Palace at Madrid; with some account of the pictures in the Buen-Retiro. London, 1787.

Arundel. 2 vols. London, 1789. [A second edition appeared in 1795, and a French translation at Paris, in 1799(?).]

Curtius rescued from the Gulph; or the Retort courteous to the Rev. Dr. Parr; in answer to his learned pamphlet [against the Rev. C. Curtis] intitled, "A Sequel," ... London, 1792.

Henry. A novel. London, 1795. [See also the Novels of Swift, Bage and Cumberland (Ballantyne's Novelist's Library), Edinburgh, 1824. 'Prefatory Memoir to Cumberland' by Walter Scott.]

MS. Notes. [by R. C.] London, 1800.

Calvary; or The Death of Christ. Burlington, 1795. [The eighth edition of this poem was published at London in 1811.]

An entire translation of the comedy of The Clouds. [The Observer. Vol. 6.] 1798.

Richard the first: a poem. [By Sir James B. Burges, . . . containing corrections and emendations suggested by $\mathrm{R}$. C., etc.] [1800.]

A poetical version of certain psalms of David. 1801. Lucani Pharsalia. [ed. by Cumberland, R.] London, 1801. 
A few plain reasons why we should believe in Christ and adhere to his religion. London, 1801.

Memoirs of Richard Cumberland, Written by Himself. containing An Account of His Life and Writings, Interspersed with Anecdotes and Characters of several of the most Distinguished Persons of his Time, With Whom He has had Intercourse and Connexion. London, 1806. [This book contains a portrait of R. C. To this volume was added in 1807 a Supplement and an Index. A second edition, including the Supplement and a different portrait of Cumberland was printed in London in 1807, in two volumes. It has been found convenient to use this edition in the present work. Another edition, with Illustrative Notes by Henry Flanders, was published in Philadelphia in 1856, adding, however, little of value to the original book.]

The Exodiad. A poem. By the authors of Calvary [R. C.] and Richard the first [James B. Burges.] London, 1807.

John De Lancaster. A Novel. 3 vols. London, 1809.

The London Review. [Conducted by R. C.] 1 vol. London, 1809.

Retrospection, A Poem, In Familiar Verse. New York, 1812.

Comicorum Graecorum Fragmenta, quae Anglicis versibus olim reddidit R. Cumberland. Cambridge, 1840.

Memoirs of Velasquez [Printed in The Works of Velasquez by George W. Reid.] London, 1872.

\section{WORKS HAVING REFERENCE TO CUMBERLAND}

[Periodicals are included in this list. Of these only the place of publication has been given. The dates of specific magazines, from which excerpts have been made, may be found in the text and notes, passim.]

Adolphus, John. Memoirs of John Bannister. 2 vols. London, 1839.

Aikin's Annual Review, London. 
The Analytical Review, London.

The Anti-Jacobin Review, London.

Archer, William. About the Theatre. London, 1886.

Armstrong, Cecil F. Shakespeare to Shaw. London, 1913.

Bagehot, Walter. Literary Studies. 2 vols. London, 1879.

Baker, David E. Biographia Dramatica; or, A Companion to the Playhouse. . . . Originally compiled, to the year 1704, by David Erskine Baker. Continued thence to 1782, by Isaac Reed, F.A.S. And brought down to the End of November 1811 . . . by Stepheiı Jones. 3 vols. [Vol. 1, in two parts, is usually bound separately.] London, 1812.

Baker, George P. Unpublished Correspondence of David Garrick. Boston, 1907.

Baker, Henry Barton. History of the London Stage and its Famous Players. 2 vols. London, 1889. [References are to the edition of London and New York, 1904.]

-Our Old Actors. 2 vols. London, 1878.

Barker, Edmund H. Literary Anecdotes. London, 1852.

Beavan, Arthur H. James and Horace Smith. London, 1899. Beloe, William. The Sexagenarian; or, The recollections of a literary life. 2 vols. London, 1817.

Bernbaum, Ernest. The Drama of Sensibility. Boston and London, 1915.

Bibliotheca Sacra, Andover, etc.

Birrell, Augustine. Men, Women, and Books. London, 1894.

[References are to the New York edition of 1894.]

Blackwood's Edinburgh Magazine, Edinburgh and London.

Boaden, James. Life of Mrs. Jordan. 2 vols. London, 1831.

[References are to the second edition, 1831.]

-Memoirs of the Life of John Philip Kemble. 2 vols. London, 1825. [References are to the edition of 2 vols. in 1, Philadelphia, 1825.]

-Memoirs of Mrs. Siddons. Interspersed with anecdotes of authors and actors. London, 1827.

Boswell, James. Letters addressed to the Rev. W. J. Temple. London, 1857. 
-Life of Samuel Johnson. Ed. by Hill, George B. 6 vols. Oxford, 1887. [References are to the New York edition of 1889.]

The British Critic, London.

The British Magazine, London.

The British Review, London.

Brydges, Egerton. Autobiography of. 2 vols. London, 1834.

Byron, Works of. Ed. by Moore, Thomas. 14 vols. London, 1832.

The Cabinet, London.

The Cabinet of Polite Literature, London.

Campbell, Thomas. Life of Mrs. Siddons. 2 vols. London, 1834. Canby, Henry S. The Short Story. New York, 1902.

Candidus. The Theater, or The Letters of Candidus. Edinburgh, 1802.

Chamberlain, Arthur B. George Romney. London and New York, 1910.

Clayden, Peter W. Early Life of Samuel Rogers. London, 1887.

[References are to the Boston edition of 1888.]

Rogers and His Contemporaries. 2 vols. London, 1889.

Colman, Francis, and Colman, George, the Elder. Posthumous Letters. London, 1820.

Colman, George, the Elder. Memoirs of Sylvester Daggerwood. London, 1806.

Constable, Thomas. Archibald Constable and His Literary Correspondents. 3 vols. Edinburgh, 1873.

The Court Miscellany, London.

Cowper, William. Correspondence of. By Wright, Thomas. 4 vols. London, 1904.

-Works of. Southey edition, 8 vols. London, 1853.

Coxe, William. Memoirs of Horatio, Lord Walpole. 2 vols. London, 1820.

Cradock, Joseph.. Literary and Miscellaneous Memoirs of. 4 vols. London, 1828.

Craik, George L. Compendious History of English Literature and of the English Language, from the Norman Conquest; 
with specimens. 2 vols. London, 1861. [References are to the New York edition of 1863.]

The Critical Review, London.

The Cumberland Letters, Being the Correspondence of Richd Dennison Cumberland and George Cumberland between the Years 1771 and 1784, ed. by Black, Clementina. London, 1912.

D'Arblay, Madame. Diary and Letters of. (1778-1840.) Ed. by Barrett, Charlotte. Preface and Notes by Dobson, Austin. 6 vols. London, 1904.

Davies, Thomas. Memoirs of the Life of David Garrick. London, 1780.

Delany, Mrs. Mary Granville. The autobiography and correspondence of Mary Granville, Mrs. Delany. 3 vols. London, 1861.

Dibdin, Charles A. A complete History of the English Stage. London [1800].

Dibdin, Mr. [Charles A.]. The professional Life of, written by himself ... London, 1803.

Dibdin, Thomas J. Reminiscences of the Theatre Royal, Covent Garden, Drury Lane, etc. 2 vols. London, 1827.

Dobson, Austin. Life of Oliver Goldsmith. (Great Writers Series.) London, 1888.

Doran, John. Annals of the English Stage. 2 vols. London, 1865. [References are to the New York edition of 1865.]

Drake, Nathan. Essays Illustrative of the Tatler, Spectator, and Guardian. 3 vols. London, 1805.

- Literary Hours. 3 vols. London, 1804.

Dramatic Censor; or, Critical Companion. [By Francis Gentleman.] 2 vols. London, 1770.

Dramaticus, Censor. A Complete History of the Drama. London, 1793.

The Dramatic Souvenir. London, 1833.

Dunham, Samuel A. Eminent Literary and Scientific Men of Great Britain and Ireland (The Cabinet Encyclopedia). 3 vols. London, 1836. 
Dunlap, William. Memoirs of the Life of George Frederick

Cooke. 2 vols. London, 1813. [References are to the New York edition of 1813.]

Earle, William. Sheridan's Life and Times, by an Octogenarian. London, 1859.

The Edinburgh Review, London.

Edwin, Eccentricities of John, Comedian, ed. by Pasquin, A. 2 vols. Dublin, 1791.

English Comic Dramatists, ed. by Crawfurd, Oswald J. London, 1883. [References are to the New York edition of 1884.]

The English Review, London.

The European Magazine, London.

Fehler, Kurt. Richard Cumberland. Leben und dramatische Werke, ein Beitrag zur Geschichte des englischen Dramas in 18 Jahrhundert. Erlangen, 1911.

Fitzgerald, Percy. Lives of the Sheridans. London, 1887.

-A new History of the English Stage. 2 vols. London, 1882. Samuel Foote, a Biography. London, 1910.

Foote, Samuel. Works of. Bee edition. 3 vols. London, 1830. Forshall, Frederick H. Westminster School Past and Present. London, 1884.

Forster, John. Life and Adventures of Oliver Goldsmith. A biography. 4 vols. London, 1848.

Foster, John. Contributions to The Eclectic Review. 2 vols. London, 1844.

Garrick, David. Private Correspondence of, with the most celebrated persons of his time. 2 vols. London, 1831-32.

Gaussen, Alice C. C. [editor]. A Later Pepys. 2 vols. London and New York, 1904.

The General Magazine, London.

Genest, John. Some Account of the English Stage, from the

Restoration in 1660 to 1830 . 10 vols. Bath, 1832 .

The Gentleman's and Lady's Weekly Magazine, London.

The Gentleman's Magazine, London. 
Goldsmith, Oliver, Miscellaneous Works of. Ed. by Prior, James. 4 vols. London, 1837.

Works of. Ed. by Cunningham, Peter. 10 vols. New York and London, 1908.

Works. Ed. by Gibbs, J. W. M.

Essay on the Theatre; or, A Comparison between Laughing and Sentimental Comedy. [First published in The Westminster Magazine for December, 1772. The essay is now included in Dobson's edition of Goldsmith's plays (BellesLettres Series) 125-30.]

Gosse, Edmund W. A History of Eighteenth Century Literature (1660-1780). London and New York, 1889.

Hayley, William. Life of George Romney. Chichester, 1809. Hazlitt, William. Conversations of James Northcote. London, 1830.

- Lectures on the English Comic Writers. London, 1819. [References are to the London edition of 1841.]

- Memoirs of the late Thomas Holcroft. 3 vols. London, 1816.

Henderson, John. Letters and poems. With anecdotes of his Life. Ed. by Ireland, John. London, 1786.

Hettner, Hermann J. Literaturgeschichte des achtzehnten Jahrhunderts. [See especially Part One.] (Die Englische Literatur von I660-1770.) Braunschweig, 1872.

Hitchman, Francis. Richard Cumberland. (Eighteenth Century Studies.) London, 1881.

Jeffrey, Francis. Memoirs of Richard Cumberland. [The Edinburgh Review.] April, 1806.

Johnson, Samuel. Letters of. Ed. by Hill, George B. 2 vols. New York, 1892.

Kelly, Hugh. Works of. London, 1778.

Kelly, Michael. Reminiscences of. 2 vols. New York, 1826.

Knight, Joseph. David Garrick. London, 1894.

The Lady's Magazine, London.

The Lady's Monthly Museum, London. 
Lewes, Charles L. Memoirs of, Written by Himself. 4 vols. London, 1805.

Lewes, George H. Life of Goethe. London, 1855. [References are to the London edition of 1890.]

Lillo, George. The London Merchant, or The History of George Barnwell, and Fatal Curiosity. Ed. by Ward, Adolphus W. (Belles-Lettres Series). Boston and London, 1906.

The Literary Journal, London.

The Literary Panorama, London.

Lloyd's Evening Post, London.

The London Chronicle.

The London Courier.

The London Examiner.

The London Magazine.

The London Quarterly Review.

The London Review.

The London Times.

Macauley, Elizabeth W. Tales of the Drama. London, 1822.

Macready, William C. Diaries of (1833-51). Ed. by Toynbee, William. 2 vols. London, 1912.

Mathews, Mrs. Charles. Memoirs of Charles Mathews. 2 vols. London, 1838-39. [References are to the Philadelphia edition of 1839.]

Meakin, Annette M. B. Hannah More. A Biographical Study. London, 1911.

Melcombe, George Bubb Dodington, Baron. The Diary of the late. London, 1809.

The Mentor, Edinburgh.

Meredith, George. An Essay on Comedy and the uses of the Comic Spirit. London, 1897. [References are to the New York edition of 1897.]

Millar, John H. The Mid-Eighteenth Century. New York, 1902.

Mitford, Mary R. Recollections of a Literary Life. New York, 1852. 
Montagu, Lady Mary Wortley. The Letters of. Ed. by Hale, Mrs. Boston, 1869.

The Monthly Review, London.

Moore, Frank F. Life of Oliver Goldsmith. London, 1910.

[References are to the New York edition of 1911.]

Moore, Thomas. Life of Sheridan. 2 vols. London, 1825.

[References are to the Philadelphia edition of 1826.]

-Memoirs, Journal, and Correspondence of. Ed. by Russell, John. 8 vols. London, 1853.

Mudford, William. Life of Richard Cumberland, Esq. embracing A Critical Examination of His Various Writings. London, 1812.

[Mr. Leslie Stephen's designation of this work as 'an impudent piece of book-making' is final. The book contains a number of Cumberland's letters, hitherto unpublished, and written while he was Secretary to the Board of Trade. These are, however, of dubious worth.]

Murphy, Arthur. Life of David Garrick. 2 vols. London, 1801.

Neele, Henry. Lectures on English Poetry. London, 1829.

Nettleton, George H. English Drama of the Restoration and Eighteenth Century (I642-1780). New York, 1914.

The New Monthly Magazine, London.

Newman, John H. Letters and Correspondence of. Ed. by Mozley, Anne. 2 vols. London, 1890.

Nichols, John B. Literary Anecdotes of the Eighteenth Century. 9 vols. London, 1812-16.

Illustrations of the Literary History of the Eighteenth Century. [A sequel to the Literary Anecdotes.] 8 vols. London, 1817-58.

Northcote, James. Memoirs of Sir Joshua Reynolds. London, 1813-15. [References are to the Philadelphia edition of 1817.]

Notes and Queries, London.

O'Keeffe, John. Recollections of. 2 vols. London, 1826.

Oulton, Walley C. History of the Theatres of London. 2 vols. 
London, 1796. Vol. 3. London, 1818. [This work continues Victor's history from 1771 to 1796 , and, in vol. 3 , to 1817.]

Oxberry's [William] Dramatic Biography. London, 1826.

The Oxford Magazine, London.

Parsons, Mrs. Clement. Garrick and his Circle. New York and London, 1906.

Paston, George. Richard Cumberland (Little Memoirs of the Eighteenth Century). London and New York, 1901.

Peake, Richard B. Memoirs of the Colman Family. 2 vols. London, 1841.

Phelps, W. M., and Robertson, Forbes. The Life and Life-work of Samuel Phelps. London, 1886.

The Philosophical Review, London.

Pope, Alexander. Poetical works of (The Aldine Poets). Ed. by Dennis, G. R. 3 vols. London and New York, 1891.

Works of. Ed. by Elwin, Whitwell, and Courthope, William. 10 vols. London, 1871.

Prior, James. Life of Oliver Goldsmith. 2 vols. London, 1837. The Public Advertiser, London.

Rae, William F. Sheridan. A Biography. 2 vols. New York, 1896.

The Reflector, London.

The Retrospective Review, London.

Reynolds, Frederick. Life and Times of. Written by Himself. 2 vols. London, 1826.

Reynolds, Sir Joshua. Life and times of. Commenced by Leslie, Charles R. Continued by Taylor, Tom. 2 vols. London, 1865.

Robinson, Henry C. Diary, Reminiscences, and Correspondence. Ed. by Sadler, Thomas. London, 1869. [References are to the second edition, 1869.]

Robinson, John R., and Hunter, H. Life of Robert Coates. London, 1891.

Roberts, William. Memoirs of the Life and Correspondence of 
Mrs. Hannah More. 2 vols. London, 1834. [References are to the New York edition of 1835.]

Rogers, Samuel. Recollections of the Table Talk of. To which is added Porsoniana. London, 1856.

The St. James Chronicle, London.

The St. James Evening Post, London.

Scot's Magazine, Edinburgh.

Scott, Walter. Journal of. 2 vols. Edinburgh, 1890. [References are to the New York edition of 1890.]

-Miscellaneous Prose Works of. 6 vols. Edinburgh, 1827. See also Novels of Swift, Bage and Cumberland.

Seilhamer, George O. History of the American Theatre. 3 vols. Philadelphia, 1888-91.

Seward, Anna. Letters of [between the years 1784 and 1807]. 6 vols. Edinburgh, 1811.

Sharpe, Charles K. Letters. Ed. by Allardyce, Alexander. Memoir by Bedford, William K. R. 2 vols. Edinburgh and London, 1888.

Sheridan, Richard B. The Major dramas of. Ed. by Nettleton, George H. (Atheneum Press Series). Boston and New York, 1906.

Sheridaniana; or, Anecdotes of the Life of Richard Brinsley Sheridan; His Table-Talk, and Bon Mots. London, 1826. Sichel, Walter. Sheridan. 2 vols. London, 1909.

Smiles, Samuel. Memoir and Correspondence of the late John Murray. 2 vols. London and New York, 1891.

Smith, Horace and James. Poetical works of. Ed. by Sargent, Epes. New York, 1857.

Smith, James. Memoirs, Letters, and Comic Miscellanies of the late. Ed. by Smith, Horace. 2 vols. London, 1840.

South Carolina. Documents Connected with the History of. [Printed for private distribution only.] London, 1856.

Stephen, Leslie. English Literature and Society in the Eighteenth Century. London, 1904.

Hours in a Library. 3 vols. London, 1874-79. 
Stuart, Letters of Lady Louisa to Miss Louisa Clinton. Ed. by

Howe, James H. Edinburgh, 1901-03.

Taylor, John. Records of My Life. New York, 1833.

Temple Bar. June, 1879. Richard Cumberland. [A nonymous.]

Theatrical Biography; or, Memoirs of the principal performers of the three Theatres Royal. 2 vols. London, 1772.

The Thespian Dictionary; or Dramatic Biography of the Eighteenth Century. London, 1802.

Thompson, Henry. Life of Hannah More. 2 vols. London and Edinburgh, 1838. [References are to the Philadelphia edition of 1858.]

Thorndyke, Ashley H. Tragedy. (Types of English Literature.)

Ed. by Neilson, William A. Boston and New York, 1908. Tinker, Chauncey B. Dr. Johnson \& Fanny Burney. New York, 1911.

The Town and Country Magazine, London.

Tuckerman, Bayard. A History of English Prose Fiction from

Sir Thomas Malory to George Eliot. New York, 1882.

The Universal Museum, London.

Victor, Benjamin. History of the Theatres of London and Dublin from the year 1730 to the present time [1771. This record was continued to 1796 and to 1817 by Walley C. Oulton.] Walpole, Horace. Correspondence of, Earl of Orford, and the Rev. William Mason. Ed. by Mitford, J. 2 vols. London, 1851.

Letters. Ed. by Toynbee, Mrs. Paget. 16 vols. London, 1904.

Memoirs of the Reign of King George the Second. 3 vols. London, 1846.

Ward, Adolphus W. A History of English Dramatic Literature to the death of Queen Ann. New and revised edition. 3 vols. London and New York, 1899.

Richard Cumberland. [The Encyclopedia Britannica.]

Waterhouse, Osborn. The Development of English Sentimental Comedy in the Eighteenth Century, in Anglia, Halle, a. S. XXX (1907), 137-72, 269-305. 
Watkins, John. Memoirs of Sheridan. 2 vols. London, 1818. Whalley, Thomas S. Journals and Correspondence of. Ed. by Wickham, Hill. 2 vols. London, 1863.

The Whitefoord Papers, being the Correspondence and other Manuscripts of Colonel Charles Whitefoord and Caleb Whitefoord from 1739-1810. Ed. by Hewins, William A. S. Oxford, 1898.

The Whitehall Evening Posț, London.

Wilkinson, Tate. Memoirs of his own Life. York, 1790.

Wordsworth, Prose Works of. Ed. by Grosart, Alexander B. 3 vols. London, 1876.

Wraxall, Sir Nathaniel W. Posthumous Memoirs of His own Time. 3 vols. London, 1836.

Wyndham, Henry S. The Annals of Covent Garden Theatre, 1732-1897. 2 vols. London, 1906.

Young, Julian C. A Memoir of C. M. Young. London and New York, 1871.

Young, Mary J. Memoirs of Mrs. Crouch. 2 vols. London, 1806. 



\section{INDEX}





\section{INDEX}

Abel, K. F., 41-2

Abington, Mrs., 84-5

Addison, Joseph, 212

Adelphi (Terence), 112

Adolphus, J., 147, 147 n, 235

Adventurer, The, 220

Aeschylus, 216

Affectation, 228

Aikin, James, 57, 259

Alcanor, 303. See The Arab

Alfred (Home), 155

All in the Wrong (Murphy), $165 \mathrm{n}$ Amelia, 43, 303

Anacreon, 280 n, 281

Analytical Reviequ, The, 232, 307

Anecdotes of eminent Painters in Spain, 185-6, $186 \mathrm{n}$

Anecdotes of Painting in England (Walpole), $185 \mathrm{n}$

Animated Nature (Goldsmith), 132

Anti-Jacobin Revieq, The, 271

Arab, The, 63, 206, 303, 321

Aristophanes, 146, 156, 218, 255.

See The Clouds

Aristotle, 150

Armageddon (Townsend), 274

Armourer, The, 229, 303

Arne, T. A., 41-2

Arnold, Samuel, 41-2

Artaxerxes (Arne), $260 \mathrm{n}$

Arundel, 226-7, 245, 248-9

Ashby, Edmund, 16

Asturias, Princess of, 180

Ausonius, 12

Austen, Jane, 264

Autobiography (Brydges), 277

Avarice, 228
Bach, J. S., 41-2

Badcock, William, 300

Bailey, James, 218

Baker, Sir George, 192

Baltimore, Lord, 70

Banishment of Cicero, The, $34 \mathrm{n}$, $39-40,45,47,61,304,321$

Bannister, John, 185, 235, 253, 2603

Barnard, Dr. Thomas, 127, 127 n, 130-1, $135 \mathrm{n}$

Barnes, Joshua, 10

Barry, Mrs., 34, 34 n, 82, 98

Barry, Spranger, 82-3, 98

Battle of Hastings, The, 109, 136$43,144 \mathrm{n}, 147,150,155,279$, 305, 321-2

Beattie, James, 105

Beauclerc, Topham, 135, 169

Beaumont and Fletcher, 54, 54 n

Beckett, Mr., 118

Beckford, William, 31, 31 n

Bell's British Dramatists, 290

Bell's Travels, 249

Bensley, Robert, 225, 225 n

Bentinck, Edward, 288 n, 300

Bentinck, Lady Edward. See Cumberland, Elizabeth

Bentley, Joanna. See Cumberland, Mrs. (mother)

Bentley, Richard (grandfather), 3$10,19,19 \mathrm{n}, 48,61,217,282$, $288 \mathrm{n}, 306$

Bentley, Dr. Richard (father's cousin), 19, $19 \mathrm{n}$

Bentley, Richard (uncle), 134, 155, 198, 222 n 
Betterton, Miss, 255

Betterton, Thomas, 153

Bickersta ff, Isaac, 41-3, 50, 73, 84

Biggin, Mrs., 287

Biographia Dramatica, 40, 42, 95, $142,205,242,293,302-4,304 \mathrm{n}$

Black Dwarf, The (Scott), $240 \mathrm{n}$

Blacket, Joseph, 290 n

Blanca, Florida, 172, 175-6, 180-1, $182 n$

Blashford, Lord, 268

Blue Stocking Club, 197-8

Boaden, James, on Parsons as Sir Fretful Plagiary, 149; on The Observer, 211; on The Country Attorney, 224; on The Jew, 231, 237; his tribute to Kemble in The Wheel of Fortune, 2401 ; on The Dependant, 253; on $A$ Word for Nature, 255; mentioned, 257-8, 298

Boddington and Sharpe, 286-7

Bondman, The (Massinger), 153, 303

Bonwicke, James, 7

Boswell, James, 101, 120, 159-60, 162, 164, 184, 264

Bourne, Vincent, 12

Box Lobby Challenge, The, 230, $306,315,318$

Boyle-Bentley Controversy, 22, 178n

British Chronicle, The, 85

British Coffee-House, The, 47 n, 93, $93 \mathrm{n}, 94 \mathrm{n}, 121,161,169$

British Critic, The, 234, 270, 294

British Essayists, The, 221

British Magazine, The, 194-5

British Museum, 267 n, 269 n, 304 n

British Review, The, 211-2, 276

Brooks, Mrs., 224, 224 n

Brothers, The, 46-59, 61, 63, 65-8, $91,142,154,305,308,310,312$, $315-6$

Brutus, 178 n
Brydges, Sir Egerton, 277, 277 n, $285 \mathrm{n}$

Bullick, governor of Georgia, 118-9 Burges, Sir J. B., 267, 267 n, 271-2, $282,286,297$

Burke, Edmund, 33, 68, 105-6, 126$7,130,169,170-1,184$

Burke, Richard, 71, 127, 127 n

Burney, Doctor, 251

Burney, Fanny, her description of Cumberland, 1; Cumberland's dislike of, 164-9; interview with the King, 192-3; on The Observer, 221; Cumberland offers assistance to, 251-2; mentioned, 117, 129, 180,196, 198, 211, 299, 299 n

Bury St. Edmund School, 8-12, 14

Byrom, John, 6-7

Byrom, Phebe, 7

Byron, Lord, 2, 257 n, 264, 274-5

Byron, Mrs., 163

Cabinet, The, 286

Cabinet of Polite Literature, The, 312

Calvary, 269, 279

Calypso, 151-2, 155, 305

Cambridge University. Trinity College. See Trinity College

Cambridge, R. O., 114, 199

Camden, William, 12

'Candidus,' 98, 98 n, 100

Canterbury, Archbishop of, 268

Capricious Lovers, The (Lloyd), $42,42 \mathrm{n}$

Caractacus, 23, 156

Carlyle, Thomas, 264

Carmelite, The, $145 \mathrm{n}, 200-4,214$, 321-2

Cato (Addison), 11

Centlivre, Mrs., 98

Character of the late Lord Viscount Sackville, 191 
Chatham, Lord, 158

Cherry, Andrew, 57, 57 n

Chesterfield, Earl of, 31, 31 n

Choleric Man, The, 111-3, 327

Cholmondeley, Mrs., 165, 165 n, 167

Church-yard Elegy, written on St. Mark's Eve, 29

Churchill, Charles, 13, 44

Cibber, Colley, 84, 85 n, 98 n, 217, $310,315,323$

Cibber, Mrs., 16-7, 34 n

Clarissa Harlowe (Richardson), 96, 215

Clarke, Hewson, 281-2

Clayden, P. W.

Clive, Kitty, 55, 85, 85 n

Clonfert, Bishop of. See Cumberland, Denison

Clouds, The (Aristophanes), Cumberland's translation of, 218, 221, 255, 304

Coelebs (More), 278-80

Cole, William, 196

Coleridge, S. T., 264

Colin and Phebe (Byrom), 6-7

Collectanea, 22

Collier, Jeremy, 150

Colman, George, the Elder, his play, The Jealous Wife, 49, $49 \mathrm{n}$; Cumberland pleased by gift of works from, 118; letter to Garrick concerning Cumberland, 157-8; produces The Country Attorney, 223-5; his connection with The Battle of Hastings, 136-8; mentioned, $13-4,45,50,63,84,110,122-$ $4,134,148,188,188 \mathrm{n}, 237 \mathrm{n}$, 324

Colman, George, the younger, $289 n$

Combe, William, 286

Comicorum Graecorum Fragmenta (Walpole), 218
Committee, The (Howard), 86

Confession, The, 265, 303-4, 324

Congreve, William, 54-5, 77, 102-

$3,113,289-90,312$

Conscious Lovers, The (Steele), 96, $96 \mathrm{n}$

Constable, Archibald, 272, 277

Cooke, G. F., 57, 86, 234, 284

Cope, Arabella, $165 \mathrm{n}$

Country Attorney, The, 223-5, 228, 303

Covent Garden Theatre, 41-4, 46, $53,53 \mathrm{n}, 55-6,136-7,136 \mathrm{n}, 147$, $151,153-4,155 \mathrm{n}, 187,193,206$, $225 \mathrm{n}, 229,253-4,255-6,257 \mathrm{n}$, $258 \mathrm{n}, 265,304 \mathrm{n}, 321$

Cowley, Abraham, 12

Cowper, William, 12, 14

Cracherode, Clayton, 13

Crane, Doctor, 25

Critic, The (Sheridan), 145-9, $169 \mathrm{n}, 196$

Critical Review, The, 51-2, 54, $54 \mathrm{n}, 145$

Croker, J. W., 286, 286 n

Cross Purposes (O'Brien), $125 \mathrm{n}$

Crouch, Mrs., 86, 241 n, 260, $260 \mathrm{n}$

Crowe, G. W., 274

Cumberland, Lady Albinia, 299, $299 n$

Cumberland, Charles (son), 133, 299

Cumberland, Denison (father), 2$4,16,28,37,64-6,113,289 \mathrm{n}$

Cumberland, Elizabeth (daughter), $166 \mathrm{n}, 172-3,180,288 \mathrm{n}, 290$, 299-300, 300 n

Cumberland, Frances Marianne (daughter), 181, $293 \mathrm{n}, 294 \mathrm{n}$, 300

Cumberland, George (cousin), 141, 152, 177, 259, 269

Cumberland, George (nephew), 134 
Cumberland, George (son), 133, 299

Cumberland, Joanna (sister), 8, 16 Cumberland, Mrs. (mother), 3, 6$8,113,212$

Cumberland, Mrs. (wife), 32-3, 61, $68,134,161,166,166 \mathrm{n}, 172$, 260,292

Cumberland, Richard, ancestry, 2; account of his grandfather, 46 ; influence of his mother, 7-8; his first dramatic effort, 7, 12; birth, childhood, and early education, 8-18; attends Bury St. Edmund School, 8-12; writes verses, 11; attends Westminster School, 12-15; death of his sister, 16; first visit to the theatre, 16-18; attends Trinity College, 19-24; opponency in mathematics, 20 , $20 \mathrm{n}$; attains high rank among The Wranglers, 21; his idea of a college education, 21-2; ill-health, 20-21, 23; becomes Secretary to Lord Halifax, 257; awarded Fellowship, 28; his description of Dodington, $31-2$; his marriage, 32-3; made Ulster secretary, 33; account of Faulkner, 34-5; refuses baronetcy, 35-6; his influence with Lord Halifax lost, 36-8; becomes Secretary to the Earl of Hillsborough, 38 ; his opinion of Lord Halifax, 38; his early dramatic efforts, 39; meets Garrick, 39-41; his quarrel with Bickerstaff, 41-3; meets 'Gentleman' Smith, 445 ; letters from Garrick to, 45 , 65, 106-7; friendship with Garrick, 47, 157-8; his stage acquaintances, 55-8; his atti- tude towards the American colonies, 59-60, 118-9; his dramatic qualifications, 61-3; Degree of Doctor of Civil Law conferred on, 74 ; his belief in moral drama, 102-3; purpose of his plays, 103-4; death of his father and mother, 113; account of Romney, 116-7; his relations with Goldsmith, 120 32; appointed Secretary of the Board of Trade, 133; his family, 133-4, 180, 299-300 ; meets Sheridan, 137; his depreciation of The School for Scandal, 144-5; his description of Soame Jenyns, 159-60; his relations with Johnson, 160-4; his dislike of Fanny Burney, 164-9; ambassadorship to Spain, 172-83; made Provost Marshal, 182; moves to Tunbridge Wells, 184; his friendship with Sackville, 189-93; relations with Walpole, 196-8; his opinion of Mrs. Montagu, 198-9; his friendship with Romney, 199-200; his personality shown in The Observer, 208-11, 218-9; as a critic, 2112 , 215-7 ; his novels, 226-7, 24550 ; his poetry, 228; his clash with Dibdin, 256-7; his clash with Reynolds, 257-8; visited by Kelly and Bannister, 2603; writes his Memoirs, 269-71; publishes The London Review, 272-5; public activities end, 277 ; his friendship with young poets, 280-91; wife's death, 292; his death, 297-8. See also the titles of individual works Cumberland, Richard (g r e a t grandfather), 2, 116 
Cumberland, Richard (g r andfather), 2, 61

Cumberland, Richard (son), 133, $166 \mathrm{n}, 299,299 \mathrm{n}$

Cumberland, Richard (uncle), 2

Cumberland, Richard $\mathrm{D}$ e $\mathrm{n}$ is on (cousin), 141, 177, 177 n

Cumberland, Richard Francis (grandson), 300

Cumberland, Sophia (daughter), $166 \mathrm{n}, 172,300$

Cumberland, William (son), 133, 299

Cunningham, Allan, 115, 117 n

Curtius Rescued from the Gulph, 222

Daly, Augustin, 84

Dampers, 207-8

Dangers of Sudden Elevation, 208 D'Arblay, Mme. See Burney, Fanny

Davies, Thomas, his Memoirs of the Life of David Garrick cited, 47; on The Brothers, 48-9, 52-3, 56-7; on The West Indian, $80,80 \mathrm{n}$; on Timon of Athens, 90; on The Battle of Hastings, 140, 143; mentioned, $120,252,313$

Dawson, Mr., $101 \mathrm{n}$

Days of Geri, The, 304

Days of Yore, The, 253-4, 318

Dedication to Detraction, 111

Defence of Christ's Miracles Against Modern Cavils, 208

Delany, Mrs., 94

Delap, John, 164 n, 167-8

De Legibus Naturae (Cumberland, great-grandfather of dramatist), 2

Dependant, The, 253, 303

Deserted Village, The (Goldsmith), 131
D'Estaing, Count, 180

DeWilde, Samuel, 149 n

Diary (Burney), 167, 192, 198-9, 299

Diary (Dodington), 32

Diary (Rogers), 282

Diary of a Lady-In-Waiting, The, 190

Dibdin, Charles, on The Banishment of Cicero, 40; on The Summer's Tale, 42-3; on The Fashionable Lover, 96-7; on The Note of Hand, 110; on The Battle of Hastings, 143; his anger at Cumberland, 257 Dibdin, Thomas, $237 \mathrm{n}, \quad 256-7$, $257 \mathrm{n}$

Dictionary of National Biography, $302 n$

Dilly, Samuel, 185, 221, 282

Diplomatic Papers of Richard Cumberland, $183 \mathrm{n}$

Dodd, J. W., 98, 98 n

Dodington, G. B., 30-2

Don Pedro, 253-4, 303

Donne, John, 12

Doran, John, 89, 143, 320

Döring, Theodore, 231

Dorset, Duke of, 165, 165 n

Double Dealer (Congreve), 54, 188

Douglas, Dr., 127, 130

Douglas (Home), $202 \mathrm{n}$

Douglass, Mr., 83-4

Dow, Alexander, $255 \mathrm{n}$

Dowton, William, 236

Drake, Sir Francis, 172

Drake, Nathan, 220

Dramatic Censor, The, 82

Drummond, Adam, 123

Drury Lane Theatre, $42 \mathrm{n}, 46 \mathrm{n}$, $49 \mathrm{n}, 53 \mathrm{n}, 54 \mathrm{n}, 55,57,71,81$, $85 \mathrm{n}, 89,93-4,96 \mathrm{n}, 98 \mathrm{n}, 106$, $109-10,137,141,143 \mathrm{n}, 144$, $150,153,188 \mathrm{n}, 201,204,225 \mathrm{n}$, 
$229,231,236,251,253-6,258$, $260 \mathrm{n}, 265-6,289 \mathrm{n}, 321$

Dryden, John, 12, 147 n

Dublin Advertiser, The, 153

Dublin, University of, 74

Duke of Milan, The, 153-4, 303

Duke of Milan (Massinger), 153-

4, $153 \mathrm{n}, 303$

Dunham, S. A., 206, 240, 240 n

Duplicity (Holcroft), $258 \mathrm{n}$

Duport, James, 15

Dying Horse, The (Blacket), $290 \mathrm{n}$

Earle, William, 147

Eatoff, Henry, 191

Eccentricities of John Edwin, The, 148

Eccentric Lover, The, 255, 303, 321

Eckhoff, Konrad, $306 \mathrm{n}$

Edinburgh Review, The, 248, 255, $270,274,277$

Edwy and Elvina (Burney), 251

Ekins Brothers, 28 n

Elders, The, 304, $304 \mathrm{n}$

Election, The, 150-1, 303

Elegy on St. Mark's Eve, 228

Elfrida (Mason), 23

Elliston, Robert, 235-6

Encyclopedia Britannica, The, $302 \mathrm{n}, 304$

English Bards and Scotch Review-

ers (Byron), 257 n, 275 n

English Review, The, 202

Envy, 211, 228

Epictetus, 249

Epistle to Dr. Arbuthnot (Pope), 30

Essay on Man (Pope), 214

Euclid, 20

European Magazine, The, 200, 203, $225,229,253-4,307$

Evans, Mr., 72

Evelina (Burney), 168-9, 221
Exodiad, The, 272

Eyre, Lord, 66

Fair Circassian, The (Pratt), 187

Fair Penitent, The (Rowe), 16, $16 \mathrm{n}, 217$

Fairy Queen (Spenser), 24

Faithful Highlander, The (alternative title to The Fashionable Lover), 98-9

False Delicacy (Kelly), 96, $96 \mathrm{n}$, $125 \mathrm{n}, 310,314$

False Demetrius, The, 265, $266 \mathrm{n}$, 303-4, 304 n, 321

False Impressions, 254, 316, 321, 327

Farquhar, George, 84, 102

Farren, Miss, 77, 86-7, 223-5, 308

Fashionable Lover, The, 88-102, $105,156,164,259,269,305-6$, $309-10,312,315,317-20$

Fatal Dowry, The (Massinger), $16 \mathrm{n}, 217$

Faulkner, George, 34, 34 n, 36 n, 68

Faulkner, Mary Anne, 36, 36 n

Faulkner, Mrs., 34

Feast of Reason, The, 221

Fenton, Elijah, 153-4

Few plain Reasons Why We Should Believe in Christ, $A$, 267

Field, Nathaniel, 217

Fielding, Henry, 30, 205, 226, 245-7, 310,321

First Love, 253, 284, 306, 308, 312, $315-6,318$

Fitzgerald, Percy, 138

Fitzherbert, William, 47, 47 n, 93 n, 105, 124

Fletcher, John. See Beaumont and Fletcher

Fletcher, Sir Robert, 119

Foote, Samuel, 30, 34, 72, 84, 93, $93 \mathrm{n}, 96 \mathrm{n}, 103,105,118-20,158$ 
Forster, John, 122, 124, 129

Foster, Vere, 7

Foundling, The (Fielding), 205, 248

Foundling, The (Moore), $98 \mathrm{n}$

Fox, Charles, 31, 31 n, 111

Fox, The (Jonson), 216

Fry, Henry, 297-8, 300

Fugitive, The (Richardson), 196

Gamester, The (Moore), 218

Garrick, David, his genius in

Rowe's Fair Penitent, 16-8;

letters from Hoadley to, $33 \mathrm{n}$; his judgment on The Banishment of Cicero, 39-40; on Timon of Athens, 45, $50 \mathrm{n}$; attends performance of The Brothers, 46-7; his Miss in her Teens, 54; Cumberland implores his judgment upon plays, 63-5; his connection with The West Indian, 68-74, $81-5,85 \mathrm{n}$; his connection with The Fashionable Lover, 91-2; his jealousy of Henderson, 107 9 ; criticism of Romney by, 1167 ; writes epitaph upon Goldsmith, 127; his connection with The Battle of Hastings, 13741 ; death of, 157 ; his opinion of Cumberland, 47, 157-8 ; mentioned, $2,41,44,50,58$, $79,86,88-9,93,93 \mathrm{n}, 105-6$, $110,119,129-30,134-6,160$, $170,217,223,257,284,298$, $305-6,313,320,326$

Garrick, Mrs., 68

Gay, John, 41

General Magazine, The, 224, 229

Genest, John, on The Summer's Tale, 42; on Amelia, 43; on The Brothers, 54; on The Fashionable Lover, 97-8; on
The Bondman, 153; on The Mysterious Husband, 195; on Don Pedro and The Days of Yore, 254; mentioned, $189 \mathrm{n}$, $203 \mathrm{n}, 229,242,255,302,304$, 311

Gentleman, Francis, 82

Gentleman's and Lady's Weekly Magazine, $255 \mathrm{n}$

Gentleman's Magazine, The, 78-9, $79 \mathrm{n}, 97,115,130,176 \mathrm{n}, 181$, $185,190-1,196$ n, 219, 223, 228, $268,300,327$

George the Third, 177

Georgics (verse translation), 228

Germain, George Sackville. See Sackville, Viscount

Gibbon, Edward, 160, 184, 264

Gifford, William, 217

Glover, Richard, 30

Godfrey, Miss, 280

Goethe, J. W. v., 306, 306 n

Goldsmith, Oliver, his characterization of Cumberland, 1 ; his dislike of sentimental drama, 120-1; his piay, She Stoops to Conquer, 122-6; his Retaliation, 126-31, 268; Cumberland's opinion of, 131-2; mentioned, 62, 93, 105, 117, 134, $150,215,264,282,309,316$

Goodman's Fields Theatre, 17

Good Natured Man, The (Goldsmith), 122

Gramont, Comte de, 106

Gray, Thomas, 114-5, 134-5, 155-6, 215,279

Gray, William, 279

Graybeard's Gossip about his Literary Acquaintance, $A$ (Smith), 284

Gray's Inn Journal (Murphy), $165 \mathrm{n}$

Green, Mrs., 55-6 
Greville, Colonel, 286

Griffith, Elizabeth, 121, 125 n, 309

Halifax, Lord, Secretaryship of Cumberland to, 24-30; chosen Lord-Lieutenant of Ireland, 33 ; death of his wife, 35 ; offers Cumberland baronetcy, 35 ; Cumberland loses influence upon, 36-8 ; mentioned, 32, 39$40,47-8,61-2,227,283$

Hamilton, W. G., 33

Hammond, James, 23, 23 n

Hanbury's Theatre, 150

Harley, Thomas, 13

Harris, George, 55-6

Hastings, Warren, 13, 197 n

Hayley, William, 197, 200

Haymarket Theatre, 109, 224, $225 \mathrm{n}, 230,253,279 \mathrm{n}, 289$

Hazlitt, William, 86, 264

Henderson, John, 107-10, 188-9, 206, 211, 284

Henry, 245-50, 254, 269

Herbert, George, 12

Hermit, The (Goldsmith), 131

Hervey, F. A., 13

Hettner, Hermann, 325

Heywood, Thomas, 195, 305

Hickey, Tom, 127, 127 n

Higgs, John, 27

Hill, Joseph, 14

Hillsborough, Earl of, 38, 174, 180

Hinchliffe, John, 14

Hint to Husbands, A, 265, 272, 312, $315,325,327$

History of India, 29

History of the Theatres of London (Victor), 49

Hitchman, Francis; 249, 299 n

Hoadley, Doctor, 33 n, 89, 91, 306, 313

Hoare, Prince, 255 n, 308, 312

Hobart, George, 13
Holcroft, Thomas, 62, 159, 185, 258-60, 309-11, 316

Holland, Lord, 283

Home, John, 155, 202 n

Homer, 5, 10

Horace, 25, 290

How to grow Rich (Reynolds), 257

Humility, 228

Hunt, Leigh, 149 n

Hunter, A. G., 277

Hussey, Abbé, 172-5, 180, 189 n, 291, $291 \mathrm{n}$

Huxley, Thomas, $282 \mathrm{n}$

Imposters, The, 229-30, 312, 324

Inchbald, Mrs., 41, 67, 81; 243-4

Ireland, W. H., 143, 143 n

Iron Chest, The (Colman), 289

Isted, Ambrose, 28, 35

James, Dr. Robert, 114-5

Jansen, Mrs. See Cumberland, Frances Marianne

Jealous Wife, The (Colman), 49, $49 \mathrm{n}$

Jeffrey, Francis, 270

Jenyns, Soame, 159-60, 169

Jephson, Robert, 251

Jew, The, 231-8, 244, 250, 284, 306, 313,315

Jew and the Doctor, The (Dibdin), $237 \mathrm{n}, 256$

Jerv of Mogadore, The, $260 \mathrm{n}, 265-$ 6,294

Joanna of Montefaucon, 265

John De Lancaster, 275-7, 295-6

Johnson, Doctor (Bishop of Worcester), 14

Johnson, Samuel, on Cumberland's patronage of Romney, 117; reads Cumberland's epitaph on Goldsmith, 127-8; social relations with Cumberland, $1(\mathrm{C}-5$; 
Cumberland's comparison of Burke and, 170-1; on The Walloons, 187; mentioned, 2, $50,62,101,105,122-4,130$, $132,158,167,169,184,197$, 221-2, 264, 282

Johnstone, John, 86

Jonathan Wild (Fielding), 32

Jonson, Ben, 216

Journal of G. F. Cooke, 57, 234

Juvenal, 11

Kaunitz, Count, 177, 180, 180 n

Keats, John, 264

Kelly, Hugh, his False Delicacy, $96,96 \mathrm{n}, 125 \mathrm{n}, 310,314$; his The Man of Reason, 136, $136 \mathrm{n}$; mentioned, $62,77,84$, 121, 125-6, 149 $159,309-12$, 316

Kelly, Michael, 145 n, 185, 241 n, 260-3, 265-6

Kemble, Charles, 240-2, 251, 267 n

King, Thomas, 81-3, 86

King Lear (Shakespeare), 81

King's Theatre, $260 \mathrm{n}$

Kinsman, Arthur, 9-11, 14

Knapp, Rev. William, 50

Knight, Joseph, 203 n

Know Your Own Mind (Murphy), $165 \mathrm{n}$

Kotzebue, A. F. F. v., 243-4

Lackington, George, 269

Lady's Magazine, The, 76, 80, 146, 201, 203-4, 238, 265

Lamb, Charles, 98, 98 n, 225 n, 235, 264

Landor, W. S., 264

Langton, Bennet, 169

Lansdowne, Lord, 283

Last of the Family, The, 254, 258, $260 \mathrm{n}, 303,318,321,325$
Laugh When You Can (Reynolds), 256

Lee, Nathaniel, 84

Lennox, Charlotte, 121-2, 125, 309

Leonidas (Glover), 30

Lewis, W. T., 86

Life of Cicero (Middleton), 39

Life of George Romney (Hayley), 200

Life of Johnson (Boswell), 126, 164

Lillo, George, 195, 310, 323

Lincoln's Inn Fields Theatre, $16 \mathrm{n}$, $153 \mathrm{n}$

Lines on the Discovery of India, 228

Literary Club, The, 163

Literary Journal, The, 328

Little French Lawyer, The (Beaumont and Fletcher), 54, $54 \mathrm{n}$

Lives of the Sheridans (Fitzgerald), 138

Llandaff, Bishop of, 222

Lloyd, Pierson, 12-3

Lloyd, Robert, 12-4, 42, 42 n

Lloyd's Evening Post, 92, 110, 112, $146,151,154-5$

Locke, John, 12

London Chronicle, The, 53, 56, 77, $86,202,253-4,300$

London Examiner, The, 294-5

London Institution, The, $283 \mathbf{n}$

London Magazine, The, 80, 110-1, 202-3

London Review, The, 42, 53-5, 95, 97, 100,142, $152 \mathrm{n}$

London Review, The (Cumberland), 272-5, 277-9, 281

London, Bishop of, 268

Lopez de la Vega, 188

Love à la Mode (Macklin), 80, $80 \mathrm{n}, 99,99 \mathrm{n}$

Love for Love (Congreve), 289 
Love in a Village (Bickerstaff), 41, 43

Love of Praise, The, 207

Lovers' Resolutions, 265, 303, 321

Lowth, Bishop, 222 n

Luxborough, Lady, 135

Lysius, Rev. Daniel, 251

Lyttleton, Lord, 81

Macbeth (Shakespeare), 278

Macklin, Charles, 55, 80, 80 n, 84, 98-9

Macnamara, Captain, 287

Macpherson, James, 105, 125, 253

Madan, Spencer, 27

Maid of Bath, The (Foote), 119

Maid of the Mill, The (Bickerstaff), 41

Maltby, William, 283, 283 n

Man, Henry, 304 n

Man of Reason, The (Kelly), 136, $136 \mathrm{n}$

Man of the World, The (Macklin), 99

Manchester, Duchess of, 152, 152 n

Mansfield, Lord, 228

Marianne (Fenton), 153-4

Mason, William, 23, 114-5, 134-5, 182, 186, 197

Massinger, Philip, 16 n, 153-4, 217

Mathews, Charles, 149, 149 n

Mattocks, Isabella, 57

Melcombe, Lord, 32

Melissa, 214

Memoirs of Mrs. Crouch, 86

Memoirs of Richard. Cumberland, $4-5,14,23,29,33,47,50,55$, $59,72,79,81,102,113,116 \mathrm{n}$, $122-3,129,134,150,160,169$, $172 \mathrm{n}, 181-2,198,228,236,247$, 249, 264, 266-7, 269-71, 279 n, $280,282,291-4,296,300,302$, 305, 308-9; Supplement, 270
Memoirs of Sheridan (Watkins), 143-4, 146

Memoirs of the Life of David Garrick (Davies), 47, 80 n

Middleton, Conyers, 39

Millar, John, 312, 324

Mills, Sir Thomas, 94, $94 \mathrm{n}$

Misanthropy and $R$ epentance (Kotzebue), 243

Miss in her Teens (Garrick), 54

Molière, J. B. P., 112

Montagu, George, 48

Montagu, Mrs., 30, 81, 118, 197-9, 221

Montgomery, Colonel, 287

Monthly Miscellany, The, 110

Monthly Review, The, 52, 76, 220, 232-3, 239, 326

Moody, John, 82-3, 93, 110

Moore, Thomas, 2, $98 \mathrm{n}, 129,264$, 274-5, 277, 280-1, 284, 295

More, Hannah, 114, 278-80, 280 n

Mouth of the Nile or The Glorious First of August (Dibdin), 256 Mudford, William, 144 n, 182, 222, 222 n, 240, 244, 292

Murphy, Arthur, Mrs. Yates in his play, The Orphan of China, $46 \mathrm{n}$; on Timon of Athens, 90; on the Dedication to Detraction, 111; favorite of Mrs. Thrale's, 165, $165 \mathrm{n}$; his criticism of Cumberland, 252; mentioned, $30,84,106,110,324$

Murray, John, 272, 276

Murray, Thomas, 116

Mysterious Husband, The, 189, 193-6, 200-1, 306, 321, 323

Mysterious Mother, The (Walpole), 193

Nanine (Voltaire), 309

Nashe, Thomas, 215 
Natural Son, The, 190, 204-5, 224, $311,313-4,320$

Neele, Henry, 329

Nelson, Lord, 172

New London Theatre (Dibdin), 256

New System of Domestic Cookery, formed upon Principles of Economy (Smith), 274 n

Newcastle, Duke of, 26

Newman, Cardinal, 268

Newton, Sir Isaac, 19

Nicolas Pedrosa, 207

Nicoll, John, 14-5, 142

Nonsense Club, The, 14

North, Lord, 132, 183 n, 184, 283

Northcote, James, $46 \mathrm{n}, 121,126$, $130,157,163,170$

Note of Hand, The, 106, 110, 143, $305,324,327$

Notion that Death may be Avoided at Will, 207

Nugent, Lord Clare, $80 \mathrm{n}$

Nuncio Colonna, The, 178

Obrallachan, Sir Callochan, 80

O'Brien, William, 122, 125, 125 n

Observer, The, $16 \mathrm{n}, 21-2,161-2$, 190, 198-200, 203 n, 206-15, 217$21,233,248,255,269,295,300$

O'Burne, King, 78, 79 n

Occasional Prelude, The, 229, 303 Ode to Doctor Robert James, 114

Ode to the Sun, 114

O'Hara, Kane, 84

O'Keeffe, John, 67, 101 n

Old Bachelor, The (Congreve), 55

On Gaming, 207-8

On the Marriage of Miss Sackville to Mr. Herbert, 190, 228

On True Greatness (Fielding), 30 O'Rourke, Thomas, anecdote of, 3-4
Orphan of China, The (Murphy), $46 n$

Ossory, Countess of, 56, 106, 197

Othello (Shakespeare), 211

Oulton, W. C., 254

Ovid, 12

Oxberry, William, 237, 289 n

Oxford Magazine, The, 53, $101 \mathrm{n}$

Palamon and Arcite, 304, $304 \mathrm{n}$

Pallavicini, Count, 178, 180

Palmer, John, 203, 203 n

Palmer, R., 258

Parr, Samuel, 222, 282-3

Parsons, William, 149, 149 n

Passive Husband, The (alternative title to $A$ Word for Nature), $255,303,324$

Patmore, Coventry, $304 \mathrm{n}$

Peltier, Monsieur, 286

Pepys, Samuel, 2

Pepys, Sir William, 279, 279 n

Percy, Thomas, 186

Percy (More), 255, 279-80

Pharsalia, 19

Philodamus (Bentley), 134, 155, $155 \mathrm{n}$

Philostratus, 216

Pic-Nic, 272, 286

Pinckney, Mr., 59, 266

Pindar, 183

Pisistratus, 208

Pitt, William, 59, 292

Pliny, 209

Poetical Epistle to Dr. Goldsmith, or Supplement to his 'Retaliation,' 130

Pope, Alexander, 4-6, 10, 30, 214, 256

Pope, Mrs. Maria Ann, 57, 206

Porson, Richard, 283 n

Portland, Duke and Duchess of, 300

Post, Mr., 94 
Posthumous Dramatick Works of Richard Cumberland, 293 n, 303, 321

Pownall, John, 26

Pratt, Samuel, 187

Pride, 228, $290 \mathrm{n}$

Priestley, Joseph, 282-3

Princess of Parma, The, 150, 303

Prior, E., 7

Prior, Matthew, 25

Prior, Sir James, 124, 126, 132

Propertius, 12

Prudery, 225

Public Advertiser, The, 147 n, 148, $151,156,186$

Puffing, 209-10

Pye, H. J., 274

Quarterly Review, The, 274, 276

Quick, John, 55-6

Quin, James, 16-7, 25, 31, 217

Rae, Alexander, 289, 289 n

Reddish, Samuel, 70-1, 85

Retaliation (Goldsmith), 1, 126-31, 268

Retrospection, 38, 134, 162, 294, 297

Review of the Samson Agonistes, 207, 216

Review of the Systems of the Heathen Philosophers, 23

Reynolds, Frederick, 257-8

Reynolds, Sir Joshua, his portrait of Garrick, $46 \mathrm{n}$; Cumberland's lines to, 130; his acquaintance with Cumberland, 169-70; mentioned, 105, 122, $127,127 \mathrm{n}, 161,163,184,186 \mathrm{n}$, 199, 264

Reynolds, Richard, 28 n

Richard Coeur de Lion (Burges), 272

Richardson, Joseph, 196

Richardson, Samuel, 226
Richmond, Duke of, 12

Ridge, Elizabeth. See Cumberland, Mrs. (wife)

Ridge, George, 32-3, 33 n

Rival, The (O'Brien), $125 \mathrm{n}$

Road to Ruin, The (Holcroft), $258 \mathrm{n}, 259$

Robber, The, 265, 303

Robinson, H. C., 272

Robson, James, 115

Rodney, Admiral, 133, 172, 175

Rogers, Samuel, 2, 4, 203 n, 211, 260, 264, 277, 280-4, 291, 295

Romance of the Forest, The, 249

Romney, George, Cumberland's description of, 115-7; his friendship for, 170, 199-200; his portraits of Cumberland, $116 \mathrm{n}$; mentioned, 2, 119, 158, 228, 291, $300 \mathrm{n}$

Rosciad (Churchill), 44

Rowe, Nicholas, 16, 16 n, 84, 217, 315

Rubens, Sir P. P., 186

Rutland Volunteers Influez'd, 251 n

Sackville, Eliza, 190

Sackville, John Frederick. See Dorset, Duke of

Sackville, Viscount, 133, 189-93

Sailor's Daughter, The, 265, 318, 328

St. James Chronicle, The, 95, 100, $112,142,146$

St. James Coffee-House, The, 127

Salome, 63, 66

Samson Agonistes (Milton), 216

Santa, Count Pietra, 179, 179 n

Saturday Review, The, 307

Saul (Southey), 272

School for Scandal, The (Sheridan), 81, 144-5, 145 n, 238

School for Widows, The, 229, 303

School for Wives, $A$ (Kelly), $125 \mathrm{n}$ 
Scot's Magazine, 110, 141

Scott, John, 197, 197 n

Scott, Sir Walter, on The Fair Penitent, $16 \mathrm{n}$; on The Summer's Tale and Amelia, 43; on The Battle of Hastings, 143; on Mathews as Sir Fretful Plagiary, 149; on Arundel, 226; on The Wheel of Fortune, 240, $240 \mathrm{n}$; on Henry, 247 ; mentioned, 2, 264, 272-3, $276-7,289,304,307,311,328$

Sedgewicke, Mr., 37

Seilhamer, G. O., 83

Sethona (Dow), $255 \mathrm{n}$

Sévigné, Mme. de, 106

Seward, Miss, 202

Shadwell, Thomas, 89-90, 103, 110, 112

Shakespear in the Shades, 7, 12, $305 \mathrm{n}$

Shakespeare, William, 7, 12, 45, $83-4,89-91,142-3,143 \mathrm{n}, 147$, $156,158,212,216,236$

Sharpe, C. K., 273, 273 n

Sharpe, Richard, 228, 287, 287 n

Shaw, R. G., 267 n

She Stoops to Conquer (Goldsmith), 122-6, 129, 169, 320, 326

Shelley, P. B., 264

Shenstone, William, 135

Sheridan, R. B., his connection with The Battle of Hastings, 13741, 1+3; his play, The School for Scandal, 14+-5; his farce, The Critic, 1+5-9; his changed attitude toward Cumberland, 265-7; Cumberland's opinion of, 150 ; mentioned, 50, 63, 105, $109,111,195-6,144 \mathrm{n}, 236,261$, $301,304 \mathrm{n}$

Sheridaniana, 144, $145 \mathrm{n}$

Shuter, Edward, 86
Sichel, W. S., $150 \mathrm{n}$

Siddons, Mrs., 202-4, 251, 283-4

Sighs, or the Daughter (Hoare), $255 \mathrm{n}$

Sir Fretfu! Plagiary, 1, 124, 145-6, $149,150,196,261,271,291,301$

Sister, The (Lennox), 122

Smith, 'Gentleman,' 44, 51, 55-6, 139

Smith, Horace, 272, 274, 277, 28491, 296

Smith, James, 274, 274 n, 277, 284, 286, 290, 301

Smith, Samuel, 14

Smollett, Tobias, 53, 57, 310

Southey, Robert, 264, 272

Spectator, The, 6, 21, 219

Spenser, Edmund, 24

Squire of Alsatia (Shadwell), 112, $112 \mathrm{n}$

Steele, Richard, 84, 96 n, 310, 315, 323

Stephen, Leslie, 244, 302 n, 313

Sterne, Laurence, 27, 135, 270

Stone, Primate, 33

Story of Melissa, The, 207

Stranger, The (Kotzebue), 243

Suett, Richard, 241 n

Suicide, The (Colman), 188, $188 \mathrm{n}$

Summer (Thomson), 30

Summer's Tale, The, 41-4, 61, 303

Swift, Jonathan, 4, 34

Sybil, The, or The Elder Brutus, $265,303,321$

Sylvester Daggerwood (Colman), $237 \mathrm{n}$

Taste (Foote), 96, $96 \mathrm{n}$

Taylor, John, $16 \mathrm{n}, 196,217,278$, $278 \mathrm{n}$

Terence, 110, 112

Thespian Dictionary, The, 83, 304 Thomson, James, 30

Thorndyke, A. H., 195 
Thornton, Bonnell, 14

Thrale, Mrs., 129, 159-60, 163-5, $166 \mathrm{n}, 167-9,187,250$

Three Weeks after Marriage (Murphy), $165 \mathrm{n}$

Tiberius, 259, 259 n, 262-3

Tiberius in Capreae, 265, 303-4, 321

Tibullus, 12

Timon of Athens, 34 n, 45, $50 \mathrm{n}$, 88-91, 112, $145 \mathrm{n}$

Timon of Athens (Shadwell), 8990

Tipper, Mr., 272

Tiranna, The, $178-80$

Titian, 178

To Oliver Goldsmith and Richard Cumberland (Barnard), 131

Tom Jones (Fielding), 245

Torrendal, 265, 303-4, 321

Touchstone (Dibdin), 257 n

Town and Country Magazine, The, $52,56,68,80,95,97,110,141$, $146,151,153,194$

Townsend, George, 274-5

Tragic Story of a Portuguese Gentleman, who died by the Rack, 214

Traveller (Goldsmith), 131

Trinity College, Cambridge, 8, 16, 19-24, 133, $274 \mathrm{n}$

Turk's Head Coffee-House, The, $278 \mathrm{n}$

Tweddell, John, 282, 282 n

Twiss, Horace, 274

Udall, Nicholas, 12

Unfortunate Traveller (Nashe), 215

Universal History, 23, $23 \mathrm{n}, 25,27$

Universal Magazine, The, 52, 112, 153, 194-5, 204-5, 232-3, 242

Upholsterer, The (Murphy), $165 \mathrm{n}$
Vanbrugh, Sir John, 113

Vandemere, John, 57

Vanity, 228

Venice Preserved (Otway), $225 \mathrm{n}$

Verses on the Death of the Prince of Wales, 228

Vicar of Wakefield, The (Goldsmith), 132

Victor, Benjamin, 49, 71

Victory and Death of Lord Nelson, The, 265, 303

Village Fête, The, 254-5, 303

Vincent, William, 14, 298-9, 299 n Voltaire, François, 309

Vortigern (Ireland), 143, 143 n

Walker, Doctor, 5-6

Walloons, The, 164, 187-9, $189 \mathrm{n}$, $303,306,316,320,324$

Walpole, Horace,. attitude of Dodington towards, $31,31 \mathrm{n}$; on The Brothers, 47-8, 56; on Timon of Athens, 89; on dedication of Cumberland's odes to Romney, 115; on The Battle of Hastings, Calypso, The Widow of Delphi, 155-6; comments on Cumberland's ambassadorship to Spain, 1823 ; on Anecdotes of eminent Painters in Spain, 186-7; his Mysterious Mother, 193; his ridicule of Cumberland, 1968 ; mentioned, $84,85 \mathrm{n}, 106$, $114,117,134-5,158,184-5$, $185 \mathrm{n}, 218$

Walsingham, Lord, $183 \mathrm{n}$

Walter, J., 39

Warburton, Bishop, 10, 40, 222 n

Ward, A. W., 302 n, 304, 325

Warren Brothers, 10-11

Warren, Sir George, 118

Warton, Thomas, 197, 197 n

Warwick, Lady, 118 
Waterhouse, Osborn, 302 n, 317, 325

Watkins, John, 143-4, 146

Way of the World, The (Congreve), 312

Weimar-Tiefurt Court Theatre, $306 \mathrm{n}$

Wellington, Duke of, 300

West, Benjamin, 199

West Indian, The, 66-89, 91-5, 101$2,105,122,126,134,142,154$, $159,188,205,205 \mathrm{n}, 228,245$, $250,254,259,260 \mathrm{n}, 269,284$, 295, 305, 315-6, 318-20, 329

Westminster Abbey, 298

Westminster Magazine, The, 145, 152, 154, 187, 205

Westminster School, 9, 12, 14-6, 133,142

Weston, Thomas, $101 \mathrm{n}, 113$

Whalley, Dr. and Mrs., 203

Wheel of Fortune, The, 231, 238$45,250,284,306,313,316,319$, 324-5, 327

Whitefoord, Caleb, 127, 127 n

Whitehall Evening Post, The, 41, $61,71,76,85,93,96,99$
Whitehead, William, 84

Widow of Delphi or The Descent of the Deities, The, 154-6, 257, 303, 305

Widow's Only Son, The, 265, 295, 303, 306

Wilkinson, Tate, $53,53 \mathrm{n}, 56$

Will, The (Reynolds), 258

Wit, 228

Woffington, Mrs., $34 \mathrm{n}$

Wonder! A Woman Keeps a Secret, The (Centlivre), 98-9, $99 \mathrm{n}$

Woodward, Henry, 55-7

Word for Nature or The Passive Husband, $A, 255,303,318$

Word to the Wise, $A$ (Kelly), 84

Wordsworth, William, 264

Wranglers, The, 21, $21 \mathrm{n}$

Wraxall, Sir N. W., 189-90

Wroughton, Richard, 57, 258

Wycherley, William, 77, 113

Yates, Mrs., 46, 46 n, 56-7, 140

Yates, Richard, 55-7

Young, Edward, 30, 85 


9 


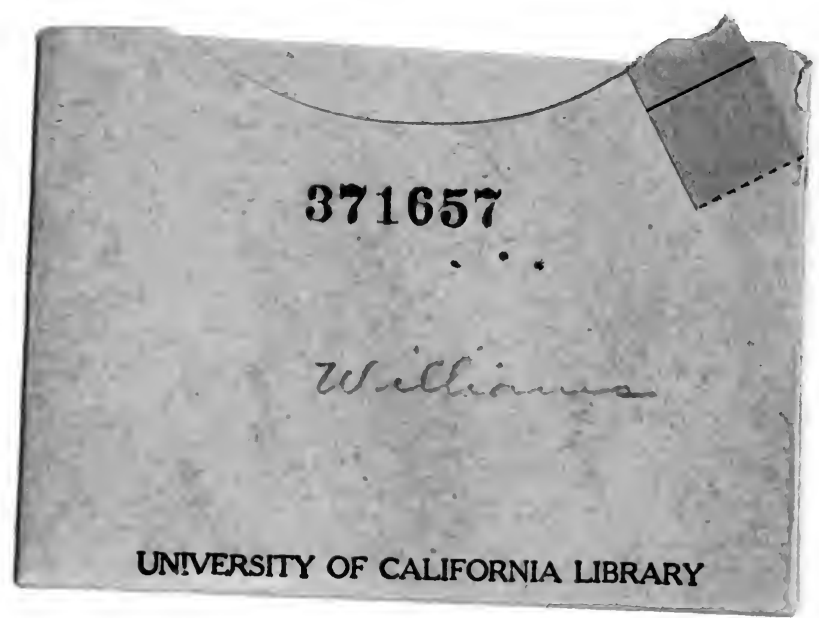


